РОССИЙСКАЯ АКАДЕМИЯ НАУК

ИНСТИТУТ СОЦИАЛЬНО-ЭКОНОМИЧЕСКОГО РАЗВИТИЯ

ТЕРРИТОРИЙ РАН

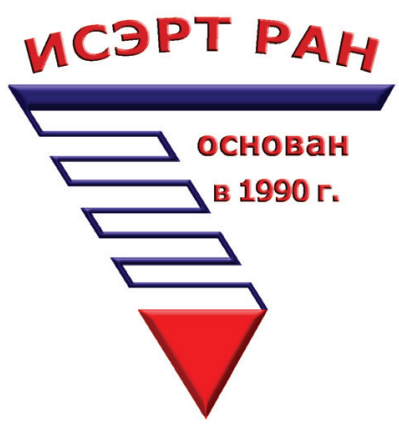

ЭКОНОМИЧЕСКИЕ

И СОЦИАЛЬНЫЕ

ПЕPЕMEHЫ:

ФАКТЫ, ТЕНДЕНЦИИ, ПРОГНОЗ 
Журнал выходит по решению руководителей экономических институтов РАН:

Северо-Западного федерального округа

Институт экономики Карельского научного центра РАН (Республика Карелия)

Институт экономических проблем им. Г.П. Лузина Кольского научного центра РАН (Мурманская область)

Институт социально-экономического развития территорий РАН (Вологодская область)

руководства

Санкт-Петербургского государственного экономического университета

Череповецкого государственного университета (Вологодская область)

других регионов РФ

Институт социально-экономических исследований Уфимского научного центра РАН (Республика

Башкортостан)

Институт экономики Уральского отделения РАН (Свердловская область)

Решением Президиума Высшей аттестационной комиссии Минобрнауки России

от 19 февраля 2010 года №6/6 журнал включён в Перечень ведущих научных изданий, рекомендуемых

для публикации основных результатов диссертаций на соискание учёной степени доктора и кандидата наук.

Журнал включён в базы данных ВИНИТИ РАН, Ulrich's Periodicals Directory, Index Copernicus International, EBSCOhost, Proquest, а также в Российский индекс научного цитирования и представлен в открытом доступе на платформе Научной электронной библиотеки (http://www. elibrary.ru).

Редакционный совет:

академик РАН В.Л. Макаров (Москва, Россия) академик РАН В.В. Ивантер (Москва, Россия) академик РАН В.В. Окрепилов (Санкт-Петербург, Россия)

академик РАН А.И. Татаркин (Екатеринбург, Россия)

академик НАН Беларуси П.А. Витязь (Минск, Беларусь)

академик НАН Беларуси П.Г. Никитенко (Минск, Беларусь)

член-корреспондент РАН В.Н. Лаженцев (Сыктывкар, Россия) проф. Ж. Сапир (Париж, Франция)

д.э.н., проф. С.Д. Валентей (Москва, Россия)

д.э.н., проф. Д.А. Гайнанов (Уфа, Россия)

Д.э.н., проф. А.Е. Дайнеко (Минск, Беларусь)

д.э.н., проф. В.А. Ильин (Вологда, Россия)

проф. М. Кивинен (Хельсинки, Финляндия)

д.с.н., проф. И.В. Котляров (Минск, Беларусь)

д.э.н., проф. С.В. Кузнецов (Санкт-Петербург, Россия)

д.э.н., проф. Ф.Д. Ларичкин (Апатиты, Россия)

Д.э.н., проф. И.А. Максимцев (Санкт-Петербург, Россия)

д.т.н., проф. А.В. Путилов (Москва, Россия)

д.т.н. Ю.Я. Чукреев (Сыктывкар, Россия)

д.т.н., проф. А.И. Шишкин (Петрозаводск, Россия)

доктор, проф. Чжан Шухуа (Пекин, Китай)

проф. У Эньюань (Пекин, Китай)

к.соц.н., Доц. Д.В. Афанасьев (Череповец, Россия)

\section{Главный редактор - В.А. Ильин}

\section{Редакционная коллегия:}

Д.э.н., проф. Л.А. Аносова

Д.э.н., проф. А.Г. Воробьев, Д.э.н., проф. Е.С. Губанова Д.э.н. К.А. Гулин (зам. главного редактора)

К.э.н. К.А. Задумкин, к.э.н. Г.В. Леонидова, к.э.н. М.Ф. Сычев (зам. главного редактора)

к.филол.н. О.В. Третьякова (зам. главного редактора, отв. секретарь)

к.э.н. С.В. Теребова, д.э.н. Т.В. Ускова, д.э.н. А.А. Шабунова

Высказанные в статьях мнения и суждения могут не совпадать с точкой зрения редакции.

Ответственность за подбор и изложение материалов несут авторы публикаций. 
THE RUSSIAN ACADEMY OF SCIENCES

INSTITUTE OF SOCIO-ECONOMIC DEVELOPMENT OF TERRITORIES OF RAS

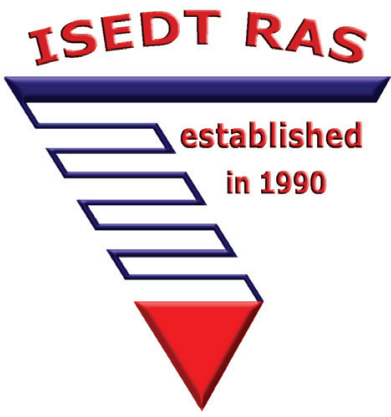

\section{ECONOMIC AND SOCIAL CHANGES:} FACTS, TRENDS, FORECAST 
The journal is published according to the decision of RAS economic institutions' administration

in the North-West Federal District

Institute of Economics of Karelian Scientific Centre of RAS (Karelia Republic)

G.P. Luzin Institute of Economic Problems of Kola Scientific Centre of RAS (the Murmansk Oblast)

Institute of Socio-Economic Development of Territories of RAS (the Vologda Oblast)

and according to the decision of the administration of

Saint Petersburg State University of Economics and Finance

Cherepovets State University (the Vologda Oblast)

and RAS institutions of other RF regions

Institute of Social and Economic Research of Ufa Science Centre of RAS (Bashkortostan Republic)

Institute of Economics of the Ural RAS Department (the Sverdlovsk Oblast)

The decision of Presidium of the Higher Attestation Commission of the Russian MES (No.6/6, dated 19.02.2010) the journal is included in the list of leading scientific editions, recommended for publication of the main results of dissertations for the degree of Doctor and Candidate of Sciences.

The journal is included into databases: VINITI RAS, Ulrich's Periodicals Directory, Index Copernicus International, EBSCOhost, Proquest, and also into the Russian Science Citation Index, and is presented in the open access on the platform of the Scientific e-Library (http://www. elibrary.ru).

Editorial Council:

RAS Academician V.L. Makarov (Moscow, Russia)

RAS Academician V.V. Ivanter (Moscow, Russia)

RAS Academician V.V. Okrepilov (St. Petersburg, Russia)

RAS Academician A.I. Tatarkin (Yekaterinburg, Russia)

Belarus NAS Academician P.A. Vityaz (Minsk, Belarus)

Belarus NAS Academician P.G. Nikitenko (Minsk, Belarus)

RAS Corresponding Member V.N. Lazhentsev (Syktyvkar, Russia)

Professor J. Sapir (Paris, France)

Doctor of Economics, Professor S.D. Valentey (Moscow, Russia)

Doctor of Economics, Professor D.A. Gaynanov (Ufa, Russia)

Doctor of Economics, Professor A.E. Dayneko (Minsk, Belarus)

Doctor of Economics, Professor V.A. Ilyin (Vologda, Russia)

Professor M. Kivinen (Helsinki, Finland)

Doctor of Sociology, Professor I.V. Kotlyarov (Minsk, Belarus)

Doctor of Economics, Professor S.V. Kuznetsov (St. Petersburg, Russia)

Doctor of Economics, Professor F.D. Larichkin (Apatity, Russia)

Doctor of Economics, Professor I.A. Maksimtsev (St. Petersburg, Russia)

Doctor of Technics, Professor A.V. Putilov (Moscow, Russia)

Doctor of Technical Sciences Yu.Ya. Chukreev (Syktyvkar, Russia)

Doctor of Technics, Professor A.I. Shishkin (Petrozavodsk, Russia)

Doctor, Professor Zhang Shuhua (Beijing, China)

Professor Wu Enyuan (Beijing, China)

Ph.D. in Sociology, Associate Professor D.V. Afanasyev (Cherepovets, Russia)

Chief Editor - V.A. Ilyin

Editorial Board:

Doctor of Economics, Professor L.A. Anosova

Doctor of Economics, Professor A.G. Vorobyov, Doctor of Economics, Professor E.S. Gubanova

Doctor of Economics K.A. Gulin (Deputy Chief Editor)

Ph.D. in Economics K.A. Zadumkin, Ph.D. in Economics G.V. Leonidova

Ph.D. in Economics M.F. Sychev (Deputy Chief Editor)

Ph.D. in Philology O.V. Tretyakova (Deputy Chief Editor, Executive Editor)

Ph.D. in Economics S.V. Terebova

Doctor of Economics T.V. Uskova, Doctor of Economics A.A. Shabunova

Opinions presented in the articles can differ from the editorial board's point of view. Authors of the articles are responsible for the material selected and stated.

ISSN 1998-0698

C) ISEDT RAS, 2014

Internet address: http://esc.vscc.ac.ru 


\section{СОДЕРЖАНИЕ}

\section{ОТ ГЛАВНОГО РЕДАКТОРА}

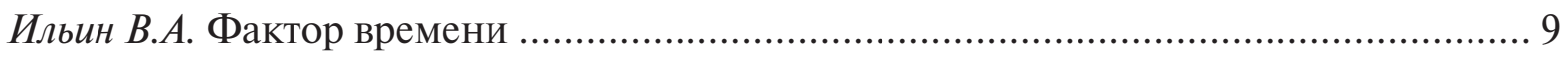

Мониторинг общественного мнения о состоянии российского общества ................ 13

\section{СТРАТЕГИЯ РАЗВИТИЯ}

Минакир П.А. О ключевых задачах экономического развития России (по итогам Послания Президента РФ Федеральному Собранию) ............................... 22

Лапин Н.И. О стратегии интегрированной модернизации ……………………….... 26

Залкинд Л.О., Торопушина Е.Е. Государственное участие в экономическом развитии Арктики России: приватизация (исторический аспект) ........... 36

\section{ВОПРОСЫ ТЕОРИИ}

Леонидова Г.В. Интеллектуальный потенциал населения:

теоретико-методологические основы исследования

\section{ОТРАСЛЕВАЯ ЭКОНОМИКА}

Беркович М.И., Комарова Е.А. Отраслевой анализ в контексте эволюционного развития экономических систем ......................................................72

Биев А.А., Шиак А.В. Возможности и перспективы появления новых нефтеперерабатывающих предприятий в северных регионах России .... 82

Шматков Н.М., Кулясова А.А., Корчагов С.А. Состояние нормативно-правовой базы и перспективы развития механизма участия общественности в управлении лесами России

\section{СОЦИАЛЬНОЕ РАЗВИТИЕ}

Беляева Л.А. Региональный социальный капитал и множественная модернизация в России. К постановке проблемы .... 108

Мигранова Л.А., Тореев В.Б., Ярашева А.В. Экономическое поведение: анализ и перспективы. 
Попова Л.А. Оценка эффективности государственных демографических инициатив

Ковригин Б.В., Синицына Т.И. К проблеме теории среднего класса: история и современность.

\section{ОБЩЕСТВЕННЫЕ ФИНАНСЫ}

Печенская М.А. Бюджетная перспектива региона 2014-2016: исполнение социальных указов Президента или избежание риска дефолта?

\section{ИННОВАЦИОННОЕ РАЗВИТИЕ}

Теребова С.В., Кузьмин И.В. Седьмая рамочная программа ЕС:

возможности для российских академических учреждений

Мa Чжихой. Оценка формирования региональной инновационной системы провинции Цзянси

Киреева А.A. Теоретико-методологические основы формирования условий развития инновационных кластеров

\section{МОДЕЛИРОВАНИЕ И ИНФОРМАТИКА}

Садов С.Л. Использование надмедианных рангов для сравнения альтернатив на долгосрочную перспективу регионального развития

\section{МОЛОДЫЕ ИССЛЕДОВАТЕЛИ}

Попов А.В. Оценка результативности трудового поведения населения на макроуровне

Академику РАН члену редакционного совета журнала Окрепилову

Владимиру Валентиновичу - 70 лет....

Требования к оформлению статей

Информация о подписке 


\section{CONTENT}

\section{FROM THE CHIEF EDITOR}

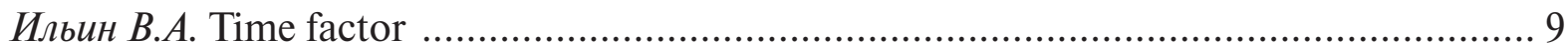

Public opinion monitoring of the state of the Russian society.......................................... 13

\section{DEVELOPMENT STRATEGY}

Minakir P.A. On the key tasks of Russia's economic development (following the Address of the RF President to the Federal Assembly) .............................................. 22

Lapin N.I. On the strategy of integrated modernization ........................................ 26

Zalkind L.O., Toropushina E.E. Participation of the state in the economic development of Russia's Arctic: privatization (historical aspect) ................................... 36

\section{THEORETICAL ISSUES}

Leonidova G.V. Intellectual potential of population: theoretical and methodological framework for research

\section{BRANCH-WISE ECONOMY}

Berkovich M.I., Komarova E.A. Branch analysis in the context of evolutionary development of economic systems

Biyev A.A., Shpak A.V. Opportunities and prospects for the emergence of new refineries in Russia's Northern regions

Shmatkov N.M., Kulyasova A.A., Korchagov S.A. Regulatory framework and development perspectives of the mechanism of public participation in the management of Russia's forests

\section{SOCIAL DEVELOPMENT}

Belyaeva L.A. Regional social capital and multiple modernization in Russia. On defining the problem 108

Migranova L.A., Toreyev V.B., Yarasheva A.V. Economic behavior: analysis and prospects 
Popova L.A. Evaluation of efficiency of the public demographic initiatives 125

Kovrigin B.V., Sinitsyna T.I. About middle class theory: history and modern times

\section{SOCIAL FINANCES}

Pechenskaya M.A. Budgetary prospects in the region in 2014-2016: implementation of the President's social decrees or avoidance of default risks?

\section{INNOVATION DEVELOPMENT}

Terebova S.V., Kuzmin I.V. The EU's Seventh Framework Programme: opportunities for Russian academic institutions 161

Ma Zhihui. Assessment of Jiangxi Regional Innovation System Construction 175

Kireyeva A.A. Theoretical and methodological framework establishing the conditions for the development of innovation clusters.

\section{MODELING AND INFORMATICS}

Sadov S.L. The use of median rank for the comparison of alternatives in the long-term ... 190

\section{YOUNG RESEARCHERS}

Popov A.V. Assessment of the effectiveness of population's labor behaviour at the macro-level

RAS Academician, the Journal's Editorial Council member Vladimir V. Okrepilov celebrates his 70th Anniversary

Requirements to manuscripts

Subscription information 


\section{ОТ ГЛАВНОГО РЕДАКТОРА}

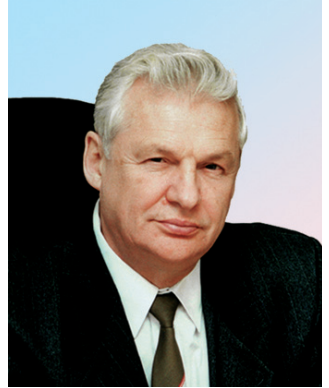

Владимир Александрович ИЛЬИН

д.э.н., профессор, заслуженный деятель науки РФ,

директор ИСЭРТ РАН ilin@vscc.ac.ru

\section{Vladimir Aleksandrovich} ILYIN

Doctor of Economics, Professor, Honoured Scientist of the Russian Federation, ISEDT RAS Director ilin@vscc.ac.ru

\section{Фактор времени Time factor}

9 февраля 2012 года кандидат в Президенты России B.В. Путин, выступая на съезде Российского союза промышленников и предпринимателей, совершенно объективно определил основную причину высокого социального напряжения в стране, сказав «...о том, что происходило в 1990-е годы, когда бизнес нередко сводился к дележу государственного пирога». «Нам, - отметил В.В. Путин, - конечно, и вот эту страницу тоже надо перевернуть... Иначе мы не сможем развить современную рыночную экономику и тем более мы не сможем создать здоровое гражданское общество... Основные решения уже должны быть приняты в 2012 году» ${ }^{1}$.

После объявленных намерений кандидата в Президенты приступить к решению этой острой проблемы прошло два года. В том числе прошло более полутора лет президентства В.В. Путина, но к реальным шагам, к сожалению, Президент не приступил.

Не обозначена эта больная для подавляющего большинства населения тема сложившейся в РФ социально несправедливой системы распределения общей государственной собственности ни в указах от 7 мая 2012 года, принятых в первый день вступления в должность Президента, ни в его первом Послании Федеральному Собранию 12 декабря 2012 года, ни во втором Послании 12 декабря 2013 года.

В речи на заседании международного дискуссионного клуба «Валдай» в сентябре 2013 года Президент В.В. Путин подчеркнул: «...Главное, что будет определять успех, - это качество людей, качество общества интеллектуальное, духовное, моральное» ${ }^{2}$.

Выступление В.В. Путина на съезде РСПП 09.02.2012 // Официальный сайт В.В. Путина. - Режим доступа: http://premier.gov.ru/events/news/18052/

2 Путин В.В. Речь на заседании международного дискуссионного клуба «Валдай» 19 сентября 2013 года [Электронный ресурс]. - Режим доступа: htpp://www.kremlin. $\mathrm{ru} /$ news/19243 
Валдайская речь В.В. Путина вызвала множество комментариев различных групп экспертов ${ }^{3}$. В обществе развернулась дискуссия о том, какой должна быть национальная идея, на каких принципах следует ее реализовать и как национализировать нашу элиту.

Во многом точку зрения экспертов, социологов и населения в отношении того, что нужно сделать для снятия накопившегося в обществе социального напряжения, выразил политолог Александр Исаев, отметив, что важно «создать новую систему контроля и распределения, когда стали бы невозможны нищие ученые, учителя и сельские жители, с одной стороны, и шикующие богатые - с другой. То, что надо что-то делать с национальными богатствами страны, сомнений нет. Антипатриотизм бизнеса и прочей элиты достиг апогея: очень многие обустроены на Западе с поместьями, счетами, с детьми в Кембриджах и Оксфордах. Огромные ресурсы отправляют туда же, с легкостью обходя все заслоны. Национализация самой элиты задача сегодняшнего дня... По моему убеждению, надо просто наводить порядок. И

См., например: Зюганов Г.: «Путин впервые заговорил о том, что страна не может без национальной идеи. Я ждал такого заявления 20 лет... Я рассматриваю выступление Путина как политическое и идеологическое обоснование крайне необходимой смены курса и отставки этого правительства» (РИА «Новости»; http:// ria.ru/politics/20131219/985234099.html\#ixzz2tw8zu6Iz); Лукьянов Ф.: «Речь Путина на Валдае содержит заявку на новую философию развития. Подход консервативный, но по-своему революционный и даже либеральный - перенос акцента с государства на человека» (РИА «Новости»; http://ria.ru/analytics/20130920/ 964803117. html\#ixzz2twHvsasi); Салин П.: Режим доступа: http:// www.lawinrussia.ru/node/285611); Щипков А.: Режим доступа: http://lgz.ru/article/-40-6433-09-10-2013/ osvobozhdenie-yazyka/); Межуев Б.: Режим доступа: http:// www.lawinrussia.ru/node/285611); Дуткевич П.: Режим доступа: РИА «Новости»; http://ria.ru/valdaiclub tenth anniversary/0131018/971014036.html\#ixzz2twHBocFN; Саймс Д.: Режим доступа: РИА «Новости»; http://ria. ru/valdaiclub tenth anniversary/ 20130921/964920156. html\#ixzz2twHTZDA7; Каррер д'Анкос: Режим доступа: РИА «Новости»; http://ria.ru/valdaiclub tenth anniversary/ 20130919/964521946.html\#ixzz2twGt5VZF. все это должен делать не какой-нибудь там департамент, а лично президент с ближайшим окружением» ${ }^{4}$.

И это надо делать не откладывая. Пренебрежение к фактору времени, выражающееся в систематическом расхождении между словом и делом, стало визитной карточкой крайне либерального финансовоэкономического блока Правительства РФ.

За провалы в экономическом развитии страны 2012-2013 гг. никто персонально не ответил: ни министры экономического блока, ни заместители Председателя Правительства, ни Председатель Правительства Д.А. Медведев. И самое печальное то, что Правительство и дальше планирует проводить прежнюю политику, которая приведет, по оценке Минэкономразвития, к снижению к 2030 г. доли РФ в глобальном ВВП почти на 20\% (с 4 до 3,4\%).

В редакционной статье «Независимая газета» отмечает, что такой прогноз министра экономического развития А.В. Улюкаева о развитии страны до 2030 г. говорит о фактическом признании того, что проводимый Правительством социально-экономический курс не может и не сможет обеспечить достойный курс развития страны ни в ближайшей, ни в отдаленной перспективе. «Власти фактически бросили вызов обществу - как минимум три пятилетки с лишним ничего не делали и даже не пытались изменить модель развития. Новый правительственный прогноз - это, по существу, диагноз нынешней политической и экономической системы, которая неспособна двигаться вперед даже средними темпами. K тому же неизвестно, насколько именно протянется новый застой. Возможно, речь идет о более длительной перспективе. Пока никто не может дать гарантию, что в 2030 году ситуация изменится. Если руководство страны практически расписывается

4 Исаев А. Национализировать надо элиту // Литературная газета. - 2014. - №6. - 12-18 февраля. 
в том, что не умеет руководить страной, но при этом остается руководить ею - это как-то странно...»

По сути, об этом же говорит и академик С.Ю. Глазьев: «Либеритарианская идеология очень удобна для ухода от ответственности за результаты экономической политики, провалы которой списываются на стихийное движение рыночных сил. При ближайшем рассмотрении выясняется, что двигают этими силами вполне конкретные люди, исходя из своих личных интересов. Подобно иллюзионистам, они выдают свои фокусы фантастического обогащения за объективные достижения предпринимательского гения, обуздавшего рыночную стихию. В действительности олигархический капитализм вырастает на одновременном провале как механизмов рыночной самоорганизации, так и институтов государственного управления. Основным источником накопления богатства является не создание новых благ, а перераспределение национального дохода за счет недофинансирования оплаты труда, воспроизводства основных фондов, присвоения природной и монопольной ренты» ${ }^{6}$.

Президент В.В. Путин, явно находившийся под влиянием крайне либеральных идей финансово-экономического блока Правительства, проявляет сейчас все больше обеспокоенности по поводу того, что фактор времени становится решающим не только в вопросе выполнения предвыборных программ, закрепленных в указах от 7 мая 2012 года, но и в вопросе места и роли России в мировом табеле о рангах. С экономически неуспешной страной, имеющей темпы роста ВВП в два раза ниже мировых, будут и разговаривать соответственно, как с «бедным родственником».

\footnotetext{
5 Три пятилетки застоя - не предел для России: редакционная статья // Независимая газета. - 2013. № 246. - 14 ноября.

6 Глазьев С.Ю. Непростительные иллюзии // Эксперт. - 2013. - №50 (880). - 16 декабря.
}

О том, что надо менять экономический курс в стране, экспертное сообщество, и в частности ученые-экономисты $\mathrm{PAH}^{7}$, говорило несколько лет назад, когда еще только начинался мировой экономический кризис, обнаживший все отрицательные итоги крайне либерального монетаристского курса Правительства.

Спад ВВП в 2009 году, достигший 8\%, был глубже, чем в промышленно развитых государствах и большинстве стран БРИКС. В.В. Путин после возвращения на пост Президента в 2012 году поручил Российской академии наук подготовить предложения по ускорению темпов экономического роста. Доклад «Россия на пути к современной, динамичной и эффективной экономике» был подготовлен в установленный срок - к 1 апреля 2013 года и направлен Президенту РФ ${ }^{8}$. И вот 19 февраля 2014 года, через 10 месяцев после представления доклада, состоялась встреча Президента с его авторами.

Президент отметил в своем вступительном слове: «Мы договорились с вами сегодня собраться, чтобы послушать ваше мнение. Я попрошу и своих коллег из Правительства, из Администрации Президента высказать свои соображения, чтобы поискать вместе конкретные меры по стимулированию экономического роста. Мы все исходим из того, что только на основе решения этой самой главной, капитальной, фундаментальной задачи можно решать

\footnotetext{
7 Макаров В.Л. Плавное начало - важный фактор оптимизации развития экономики // Экономика и общество. - 2007. - №11-12; Григорьев Л., Овчинников М. Коррупция как препятствие модернизации (институциональный подход) // Вопросы экономики. - 2008. - №2; Болдырев Ю. Еще раз о содержании формулы «Россия энергетическая держава» // Российский экономический журнал. - 2008. - №3-4; Губанов С.С. Неоиндустриализация плюс вертикальная интеграция (о формуле развития России) // Экономист. - 2008. - №9 и др.

8 Полный текст доклада размещён в Интернете. Режим доступа: http://www.ras.ru/news/shownews.aspx?id

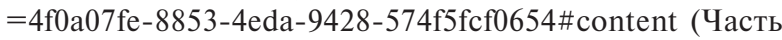
доклада опубликована в журнале «Экономические и социальные перемены: факты, тенденции, прогноз». 2013. - №6(30). - C. 18-31.)
} 
задачи опережающего развития экономики и социальной сферы. Без этого ничего сделать невозможно, но это тем более актуально, что в данный момент Правительство РФ готовит долгосрочный прогноз социально-экономического развития страны до 2030 года. Поэтому наша сегодняшняя встреча в высшей степени востребована. Нами должна быть разработана и заявлена внятная политика по мобилизации всех имеющихся ресурсов для ускоренного роста» 9 .

Бросается в глаза отсутствие на встрече Председателя Правительства Д.А. Медведева и профильных вице-премьеров И.И. Шувалова и А.В. Дворковича. Это показывает, что Президент переходит на ручное управление, так как команда Председателя Правительства не в состоянии справиться с задачами поддержания стабильного и динамичного экономического роста. Следует обратить внимание на слова Президента о том, что Правительство готовит долгосрочный прогноз социально-экономического развития страны до 2030 года.

А как тогда понимать прогноз социально-экономического развития РФ до 2030 года министра экономического развития А.В. Улюкаева, о котором со справедливым возмущением писала «Независимая газета» три месяца назад? (14.11.2013 г.)

Такой прогноз можно понять как давление на Президента, на его стремление выполнить свои предвыборные программы, зафиксированные в указах от 7 мая 2012 года, как попытку затормозить реализацию идей, высказанных Президентом в Валдайской речи.

Эти идеи полностью расходятся с той практикой, которую долгие годы проводили крайне либеральный экономический блок Правительства и значительная часть правящей элиты.

9 Встреча с учёными-экономистами РАН // Официальный сайт Президента России. - Режим доступа: http:/ www.kremlin.ru/news/20291
Как подчеркнул В.В. Путин, «практика показала, что новая национальная идея не рождается и не развивается по рыночным правилам. Самоустранение государства не сработало, так же как и механическое копирование чужого опыта. Такие грубые заимствования, попытки извне цивилизовать Россию не были приняты абсолютным большинством нашего народа, потому что стремление к самостоятельности, к духовному, идеологическому, внешнеполитическому суверенитету - неотъемлемая часть нашего национального характера» ${ }^{10}$.

Президент дал жесткую оценку значительной части правящей элиты: «Кроме того, отсутствие национальной идеи, основанной на национальной идентичности, было выгодно той квазиколониальной части элиты, которая предпочитала воровать и выводить капиталы и не связывала своё будущее со страной, где эти капиталы зарабатывались» ${ }^{11}$.

Заявленный Президентом в Валдайской речи курс на базовые общественные ценности, моральный консенсус в обществе возможен только при национализации элит. «Надо вернуть элиту и её деньги в страну, поставить их капиталы под контроль государства, навести порядок с налогами, отменив плоскую шкалу, и взять фактически тем самым недра под контроль государства. Совершив это, начать аккумулировать средства для кардинального подъема страны, определив основные пути развития экономики» ${ }^{12}$.

И здесь фактор времени для реализации нового курса В.В. Путина будет иметь решающее значение.

${ }^{10}$ Путин В.В. Речь на заседании международного дискуссионного клуба «Валдай» 19 сентября 2013 года [Электронный ресурс]. - Режим доступа: htpp://www. kremlin.ru/news/19243

${ }_{11}$ Там же.

${ }^{12}$ Исаев А. Национализировать надо элиту // Литературная газета. - 2014. - №6. - 12-18 февраля. 


\section{Мониторинг общественного мнения о состоянии российского общества}

Продолжая сложившуюся традицию нашего издания, приводим результаты мониторинговых оценок общественного мнения о состоянии российского общества, выполняемых ИСЭРТ РАН в Вологодской области ${ }^{1}$.

Нижеследующие таблицы показывают динамику ряда параметров социального самочувствия и общественно-политических настроений населения Вологодской области в среднем за последние 6 опросов, проведенных за период с апреля 2013 по февраль 2014 г., дается сопоставление их с данными за 2012 г., а также за 2011 год, когда шёл к окончанию срок пребывания в должности Президента РФ Д.А. Медведева, и за 2007 год, когда завершался второй срок президентской деятельности В.В. Путина.

\section{Оценка деятельности власти}

В среднем за последние 6 опросов по сравнению с 2012 г. улучшились оценки деятельности Президента РФ (доля положительных отзывов увеличилась на 4 п.п.). Однако ситуация остается менее благоприятной, чем в 2011 (последний год президентства Д.А. Медведева) и 2007 гг. (последний год второго президентского срока В.В. Путина). По-прежнему не наблюдается позитивных изменений в оценке деятельности Правительства РФ. Отмечается повышение уровня оценок деятельности губернатора Вологодской области.

Таблица 1. Динамика ответов на вопрос: «Как Вы оцениваете в настоящее время деятельность..?» (в \% от числа опрошенных)

\begin{tabular}{|c|c|c|c|c|c|c|c|c|c|c|c|c|c|c|}
\hline \multirow[t]{2}{*}{ Показатель } & \multirow[t]{2}{*}{2007} & \multirow[t]{2}{*}{2011} & \multirow[t]{2}{*}{2012} & \multirow[t]{2}{*}{2013} & \multirow[t]{2}{*}{$\begin{array}{l}\text { Апр. } \\
2013\end{array}$} & \multirow[t]{2}{*}{$\begin{array}{l}\text { Июнь } \\
2013\end{array}$} & \multirow[t]{2}{*}{$\begin{array}{l}\text { Авг. } \\
2013\end{array}$} & \multirow[t]{2}{*}{$\begin{array}{l}\text { Окт. } \\
2013\end{array}$} & \multirow[t]{2}{*}{$\begin{array}{l}\text { Дек. } \\
2013\end{array}$} & \multirow[t]{2}{*}{$\begin{array}{l}\text { Янв. } \\
2014\end{array}$} & \multirow{2}{*}{$\mid$\begin{tabular}{||c} 
Среднее \\
за послед- \\
ние \\
6 опросов
\end{tabular}} & \multicolumn{3}{|c|}{$\begin{array}{c}\text { Изменение (+/-), } \\
\text { последние } 6 \text { опросов } \\
\text { по отношению к }\end{array}$} \\
\hline & & & & & & & & & & & & 2012 & 2011 & 2007 \\
\hline \multicolumn{15}{|c|}{ Президент РФ } \\
\hline Одобряю & 75,3 & 58,7 & 51,7 & 55,3 & 55,5 & 54,3 & 55,1 & 54,3 & 57,3 & 56,1 & 55,4 & +4 & -3 & -20 \\
\hline Не одобряю & 11,5 & 25,6 & 32,6 & 29,4 & 31,5 & 29,3 & 28,9 & 28,7 & 28,9 & 29,3 & 29,4 & -3 & +4 & +18 \\
\hline \multicolumn{15}{|c|}{ Председатель Правительства РФ* } \\
\hline Одобряю & - & 59,3 & 49,6 & 48,9 & 48,5 & 46,2 & 50,4 & 49,0 & 51,1 & 49,3 & 49,1 & -1 & -10 & - \\
\hline Не одобряю & - & 24,7 & 33,3 & 32,8 & 35,7 & 33,2 & 30,4 & 30,6 & 32,5 & 32,9 & 32,6 & -1 & +8 & - \\
\hline \multicolumn{15}{|c|}{ Губернатор } \\
\hline Одобряю & 55,8 & 45,7 & 41,9 & 44,4 & 44,4 & 44,3 & 44,8 & 45,9 & 44,1 & 42,8 & 44,4 & +3 & -1 & -11 \\
\hline Не одобряю & 22,2 & 30,5 & 33,3 & 33,2 & 34,9 & 31,9 & 31,1 & 32,4 & 35,3 & 36,9 & 33,8 & +1 & +3 & +12 \\
\hline
\end{tabular}

Опросы проводятся 6 раз в год в Вологде, Череповце и в восьми районах области (Бабаевском, Великоустюгском, Вожегодском, Грязовецком, Кирилловском, Никольском, Тарногском и Шекснинском). Метод опроса - анкетирование по месту жительства респондентов. Объем выборочной совокупности - 1500 человек в возрасте 18 лет и старше. Выборка целенаправленная, квотная. Репрезентативность выборки обеспечена соблюдением пропорций между городским и сельским населением, пропорций между жителями населенных пунктов различных типов (сельские населенные пункты, малые и средние города), половозрастной структуры взрослого населения области. Ошибка выборки не превышает $3 \%$.

Более подробную информацию о результатах опросов, проводимых ИСЭРТ РАН, можно найти на сайте http:// www.vscc.ac.ru/. 


\section{Оценка социального состояния}

Доля позитивных оценок социального настроения и запаса терпения в среднем за последние 6 опросов выше, чем была в 2012, 2011 и 2007 гг. (68 и $80 \%$ соответственно).

Однако по сравнению с 2012 г. незначительно возрос удельный вес жителей, относящих себя к «бедным» и «нищим» слоям населения (47\%). На протяжении периода с апреля 2013 по февраль 2014 г. их доля практически не изменялась.

Таблица 2. Оценка социального состояния (в \% от числа опрошенных)*

\begin{tabular}{|c|c|c|c|c|c|c|c|c|c|c|c|c|c|c|}
\hline & \multirow[t]{2}{*}{2007} & \multirow[t]{2}{*}{2011} & \multirow[t]{2}{*}{2012} & \multirow[t]{2}{*}{2013} & \multirow[t]{2}{*}{$\begin{array}{l}\text { Апр. } \\
2013\end{array}$} & \multirow[t]{2}{*}{$\begin{array}{l}\text { Июнь } \\
2013\end{array}$} & \multirow[t]{2}{*}{$\begin{array}{l}\text { Авг. } \\
2013\end{array}$} & \multirow[t]{2}{*}{$\begin{array}{l}\text { ОКт. } \\
2013\end{array}$} & \multirow[t]{2}{*}{$\begin{array}{l}\text { Дек. } \\
2013\end{array}$} & \multirow[t]{2}{*}{$\begin{array}{l}\text { Фев. } \\
2014\end{array}$} & \multirow{2}{*}{$\begin{array}{c}\text { Среднее } \\
\text { за послед- } \\
\text { ние } \\
6 \text { опросов }\end{array}$} & \multicolumn{3}{|c|}{$\begin{array}{c}\text { Изменение (+/-), за } \\
\text { последние } 6 \text { опросов } \\
\text { по отношению к }\end{array}$} \\
\hline & & & & & & & & & & & & 2012 & 2011 & 2007 \\
\hline \multicolumn{15}{|c|}{ Настроение } \\
\hline $\begin{array}{l}\text { Нормальное состо- } \\
\text { яние, прекрасное } \\
\text { настроение }\end{array}$ & 63,6 & 63,1 & 67,3 & 68,6 & 68,6 & 66,4 & 68,7 & 71,5 & 69,6 & 65,1 & 68,3 & +1 & +5 & +5 \\
\hline $\begin{array}{l}\text { Испытываю напря- } \\
\text { жение, раздраже- } \\
\text { ние, страх, тоску }\end{array}$ & 27,8 & 28,9 & 27,0 & 26,2 & 26,0 & 25,9 & 26,3 & 24,0 & 26,2 & 27,1 & 25,9 & -1 & -3 & -2 \\
\hline \multicolumn{15}{|c|}{ Запас терпения } \\
\hline $\begin{array}{l}\text { Всё не так плохо и } \\
\text { жить можно; жить } \\
\text { трудно, но можно } \\
\text { терпеть }\end{array}$ & 74,1 & 74,8 & 76,6 & 79,3 & 77,9 & 77,8 & 79,7 & 81,6 & 83,1 & 79,8 & 80,0 & +3 & +5 & +6 \\
\hline $\begin{array}{l}\text { Терпеть наше бед- } \\
\text { ственное положе- } \\
\text { ние невозможно }\end{array}$ & 13,6 & 15,3 & 15,8 & 14,2 & 16,5 & 13,7 & 14,7 & 12,3 & 12,0 & 12,3 & 13,6 & -2 & -2 & 0 \\
\hline \multicolumn{15}{|c|}{ Социальная самоидентифрикация } \\
\hline $\begin{array}{l}\text { Доля считающих } \\
\text { себя людьми сред- } \\
\text { него достатка }\end{array}$ & 48,2 & 43,1 & 44,7 & 43,9 & 42,6 & 41,9 & 44,9 & 45,7 & 43,7 & 44,2 & 43,8 & -1 & +1 & -4 \\
\hline $\begin{array}{l}\text { Доля считающих } \\
\text { себя бедными и } \\
\text { нищими }\end{array}$ & 42,4 & 44,3 & 44,5 & 46,9 & 48,2 & 48,3 & 46,8 & 45,4 & 46,7 & 46,9 & 47,1 & +3 & +3 & +5 \\
\hline \multicolumn{15}{|c|}{ Индекс потребительских настроений } \\
\hline $\begin{array}{l}\text { Значение индекса, } \\
\text { в пунктах }\end{array}$ & 105,9 & 89,6 & 91,5 & 90,3 & 90,4 & 89,8 & 91,0 & 90,4 & 87,9 & 91,5 & 90,2 & -1 & +1 & -16 \\
\hline
\end{tabular}

\footnotetext{
* Ранжировано по среднему значению индекса успешности за последние 6 опросов. Для расчета индекса из доли положительных ответов вычитается доля отрицательных, затем к полученному значению прибавляется 100, чтобы не иметь отрицательных величин. Таким образом, полностью отрицательные ответы дали бы общий индекс 0 , положительные - 200, равновесие первых и вторых выражает значение индекса 100, являющееся, по сути, нейтральной отметкой. У индекса социальной напряженности - обратный порядок значений: отметка 0 пунктов является абсолютно положительной величиной, 200 пунктов - абсолютно отрицательной величиной.
} 


\section{Отношение населения к политическим партиям}

Поддержка партии власти в среднем за последние 6 опросов составила 29\%, что находится в рамках показателей предшествующих лет.

Опасения вызывает постепенный рост удельного веса людей, считающих, что ни одна из представленных на сегодняшний день политических партий не выражает их интересов (в 2007 г. $-18 \%$, в 2011 г. - 29\%, в 2012 г. - 31\%, в среднем за последние 6 опросов $-35 \%)$.

Таблица 3. Какая партия выражает Ваши интересы? (в \% от числа опрошенных)

\begin{tabular}{|c|c|c|c|c|c|c|c|c|c|c|c|c|c|c|c|c|}
\hline \multirow[t]{2}{*}{ Партия } & \multirow[t]{2}{*}{2007} & \multirow{2}{*}{ 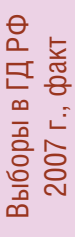 } & \multirow[t]{2}{*}{2011} & \multirow{2}{*}{ 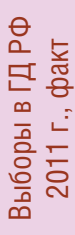 } & \multirow[t]{2}{*}{2012} & \multirow[t]{2}{*}{2013} & \multirow[t]{2}{*}{$\begin{array}{l}\text { Апр. } \\
2013\end{array}$} & \multirow[t]{2}{*}{$\begin{array}{l}\text { Июнь } \\
2013\end{array}$} & \multirow[t]{2}{*}{$\begin{array}{l}\text { Авг. } \\
2013\end{array}$} & \multirow[t]{2}{*}{$\begin{array}{l}\text { Окт. } \\
2013\end{array}$} & \multirow[t]{2}{*}{$\begin{array}{l}\text { Дек. } \\
2013\end{array}$} & \multirow[t]{2}{*}{$\begin{array}{l}\text { Фев. } \\
2014\end{array}$} & \multirow{2}{*}{$\begin{array}{c}\text { Среднее } \\
\text { за послед- } \\
\text { ние } \\
6 \text { опросов }\end{array}$} & \multicolumn{3}{|c|}{$\begin{array}{c}\text { Изменение (+/-), } \\
\text { за последние } \\
6 \text { опросов } \\
\text { по отношению к }\end{array}$} \\
\hline & & & & & & & & & & & & & & 2012 & 2011 & 2007 \\
\hline $\begin{array}{l}\text { Единая } \\
\text { Россия }\end{array}$ & 30,2 & 60,5 & 31,1 & 33,4 & 29,1 & 29,4 & 28,5 & 31,3 & 29,6 & 26,9 & 29,5 & 28,3 & 29,0 & 0 & -2 & -1 \\
\hline КПРФ & 7,0 & 9,3 & 10,3 & 16,8 & 10,6 & 11,3 & 11,0 & 11,3 & 12,0 & 11,9 & 11,8 & 10,9 & 11,5 & +1 & +1 & +5 \\
\hline ЛДПР & 7,5 & 11,0 & 7,8 & 15,4 & 7,8 & 7,2 & 7,1 & 6,6 & 6,8 & 8,4 & 8,1 & 8,9 & 7,7 & 0 & 0 & 0 \\
\hline $\begin{array}{l}\text { Справедливая } \\
\text { Россия }\end{array}$ & 7,8 & 8,8 & 5,6 & 27,2 & 6,6 & 4,6 & 5,1 & 4,7 & 4,3 & 4,0 & 4,4 & 3,5 & 4,3 & -2 & -1 & -4 \\
\hline Другая & 1,8 & - & 1,9 & - & 2,1 & 0,6 & 3,4 & 2,0 & 3,4 & 1,0 & 0,8 & 0,4 & 1,8 & 0 & 0 & 0 \\
\hline Никакая & 17,8 & - & 29,4 & - & 31,3 & 34,9 & 37,1 & 31,7 & 33,4 & 37,3 & 34,4 & 35,2 & 34,9 & +4 & +6 & +17 \\
\hline $\begin{array}{l}\text { Затрудняюсь } \\
\text { ответить }\end{array}$ & 21,2 & - & 13,2 & - & 11,7 & 10,2 & 7,8 & 12,3 & 10,5 & 10,5 & 10,9 & 12,7 & 10,8 & -1 & -2 & -10 \\
\hline
\end{tabular}


Ниже помещены результативные показатели многолетних измерений ИСЭРТ РАН по оценке отношения населения Вологодской области к действующим властным и общественно-политическим институтам.

Представленные при этом графические материалы по сравнению с опубликованными нами ранее учитывают результаты измерений, полученные в период третьего срока пребывания В.В. Путина на должности Президента РФ, в том числе в целом за 2013 год.

Как видно из этих данных, имевший место в 2000-2008 гг. резкий (по сравнению с периодом президентства Б.Н. Ельцина) рост доверия к президенту в лице В.В. Путина сменился постоянным снижением доверия к президентской власти (в лице Д.А. Медведева) в 2009-2012 гг. и пока не восстановлен.
Отметим сохраняющееся относительно высокое доверие к церкви. Значение доверительного индекса здесь выше, чем у государственных структур и большинства общественно-политических институтов, и характеризуется стабильной устойчивостью во все периоды социологических измерений.

Вместе с тем уже ряд лет наблюдается рост доверия населения к деятельности судебных органов. В 2013 году произошел позитивный сдвиг в доверии к деятельности прокуратуры, ФСБ, армии, полиции тех институтов, которые являются важнейшими звеньями прочности государственной системы.

Пока не удаётся переломить спад последних лет в отношении доверия к деятельности Государственной Думы и Совета Федерации, что свидетельствует о том, что система организации отечественного законодательства несвоевременно реагирует на формирование правовых основ.

\section{Отношение к деятельности Президента РФ}

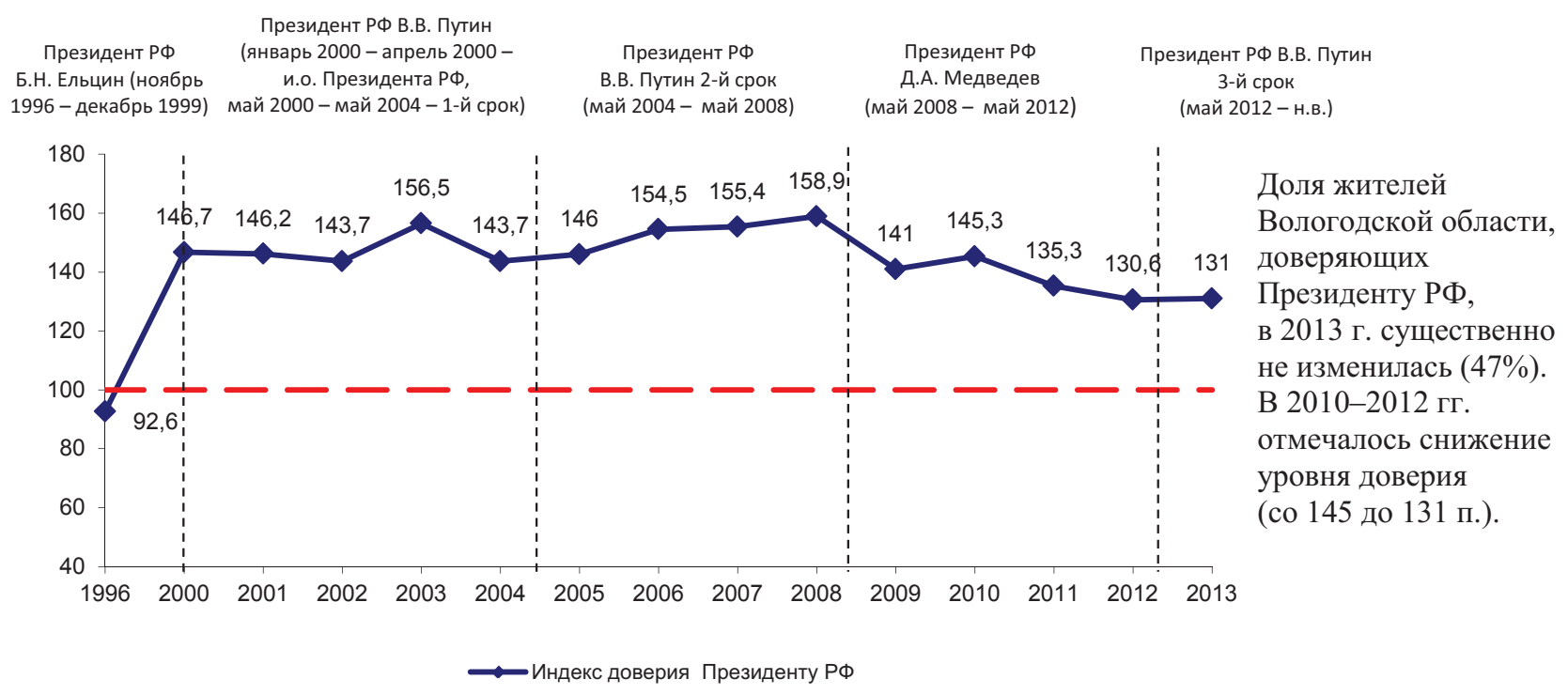




\section{Отношение к деятельности церкви}

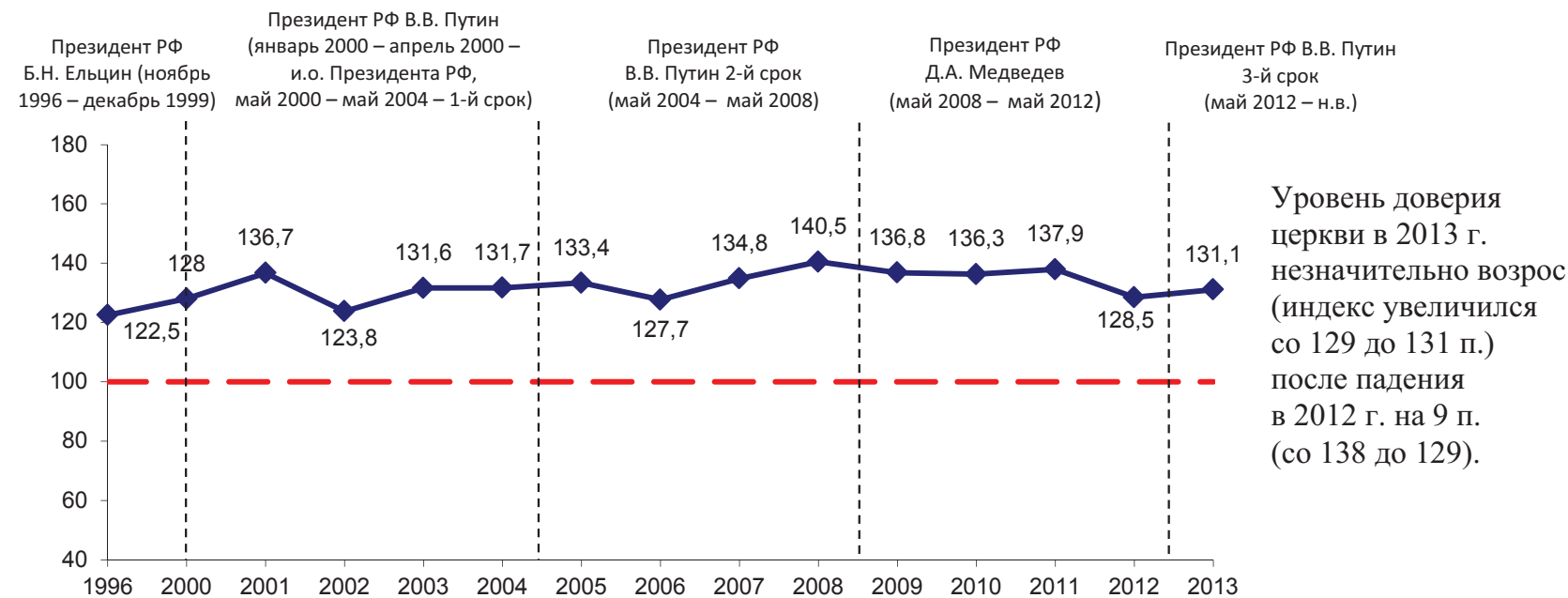

— Индекс доверия церкви

\section{Отношение к деятельности Правительства РФ}

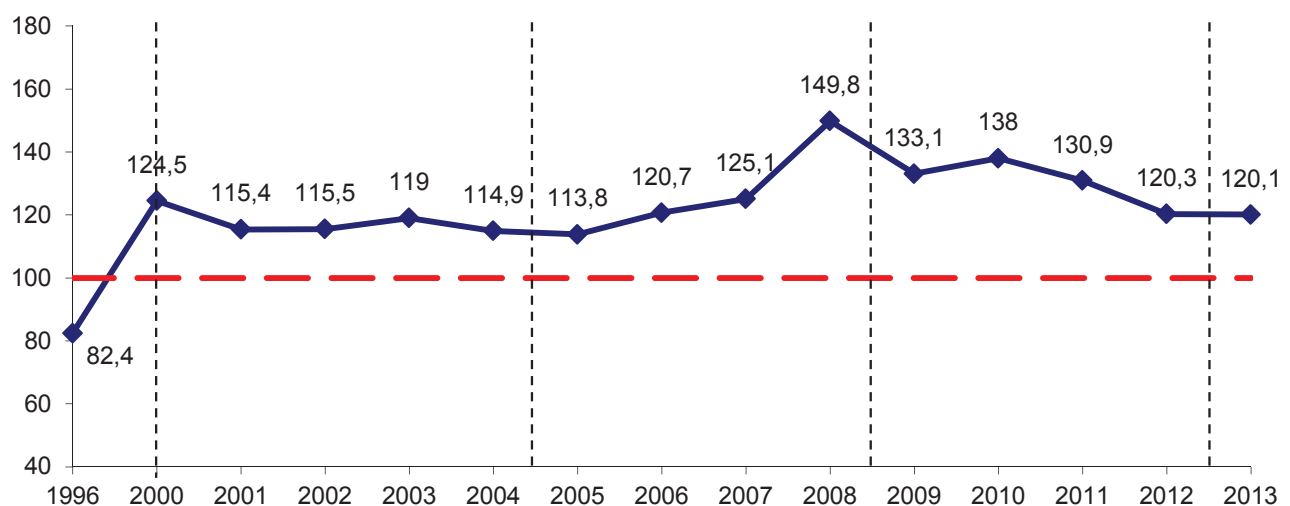

Индекс доверия Правительству РФ после снижения в 2010-2012 гг (со 138 до 120 п.) стабилизировался.

— Индекс доверия Правительству РФ

\section{Отношение к деятельности суда}

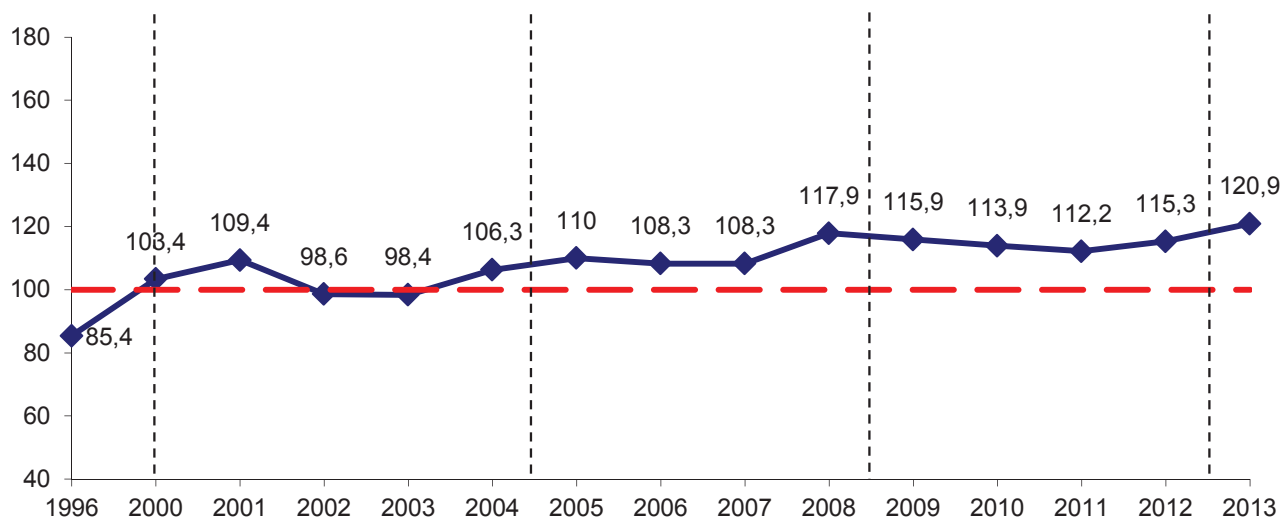

Уровень доверия жителей области к суду увеличивается с 2011 г. За этот период индекс возрос на 9 п. (со 112 до 121).

—Индекс доверия суду 


\section{Отношение к деятельности руководства области}

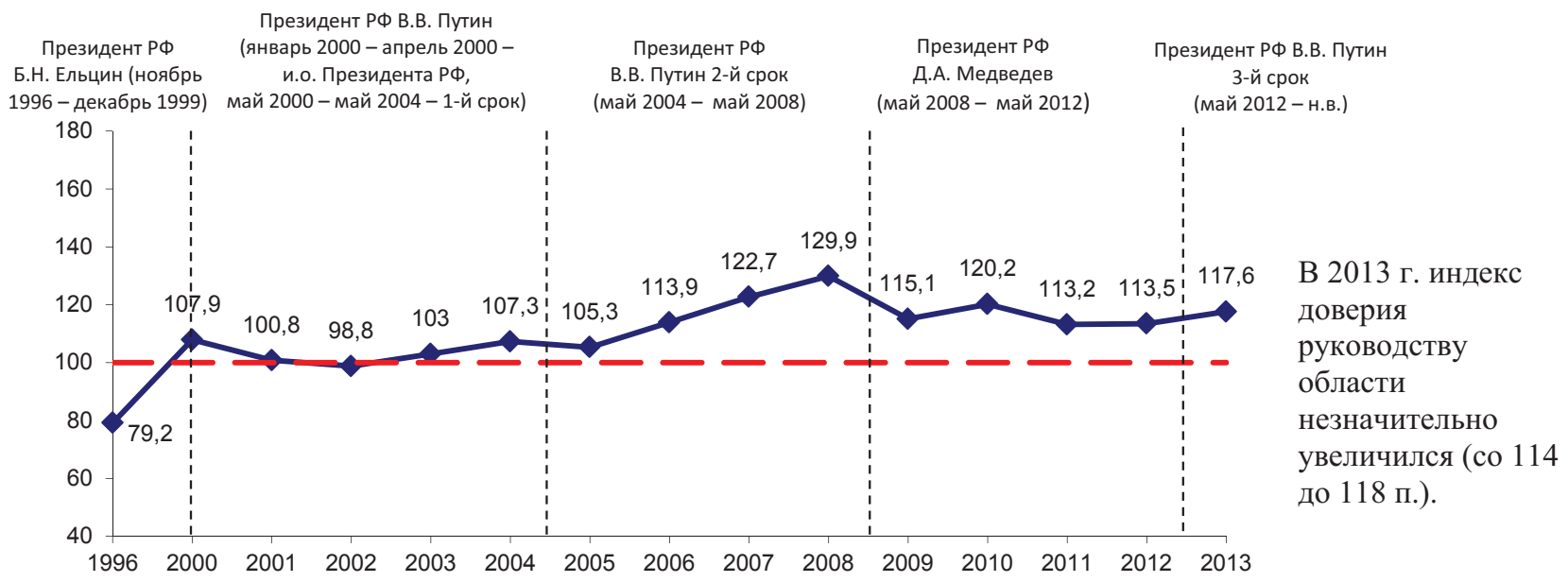

- Индекс доверия руководству области

\section{Отношение к деятельности прокуратуры}

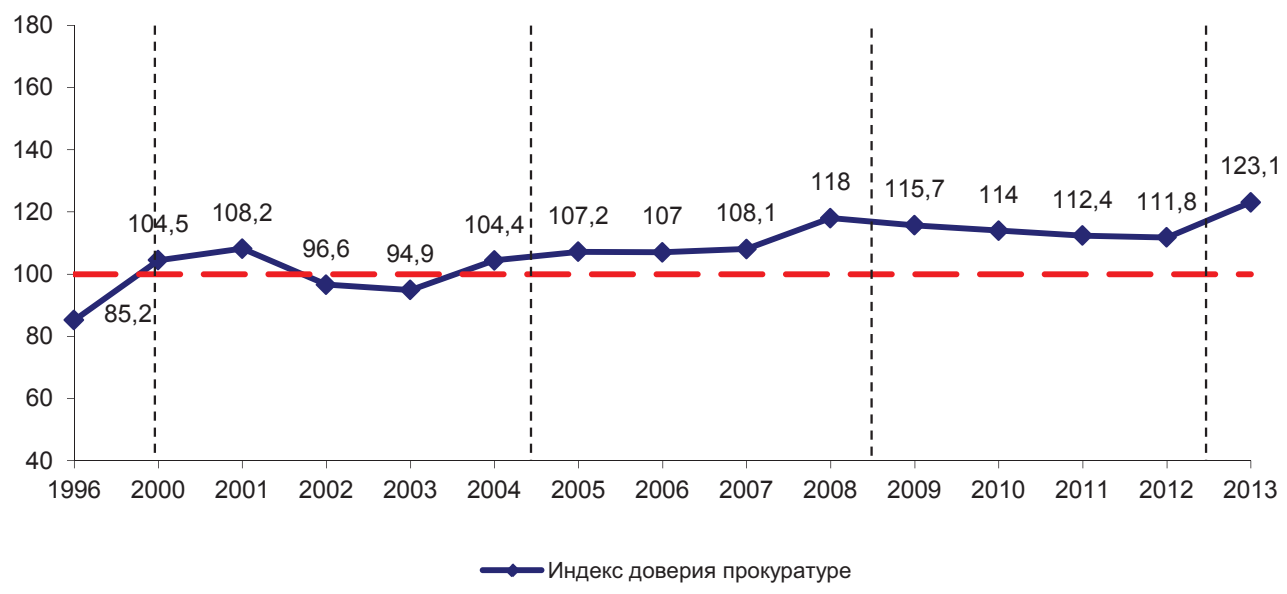

Уровень доверия прокуратуре в 2013 г. существенно увеличился (со 118 до 129 п.).

Противоположная тенденция отмечалась в 2008- 2012 гг.

(за этот период индекс снизился со 118 до 112 п.).

\section{Отношение к деятельности ФСБ}

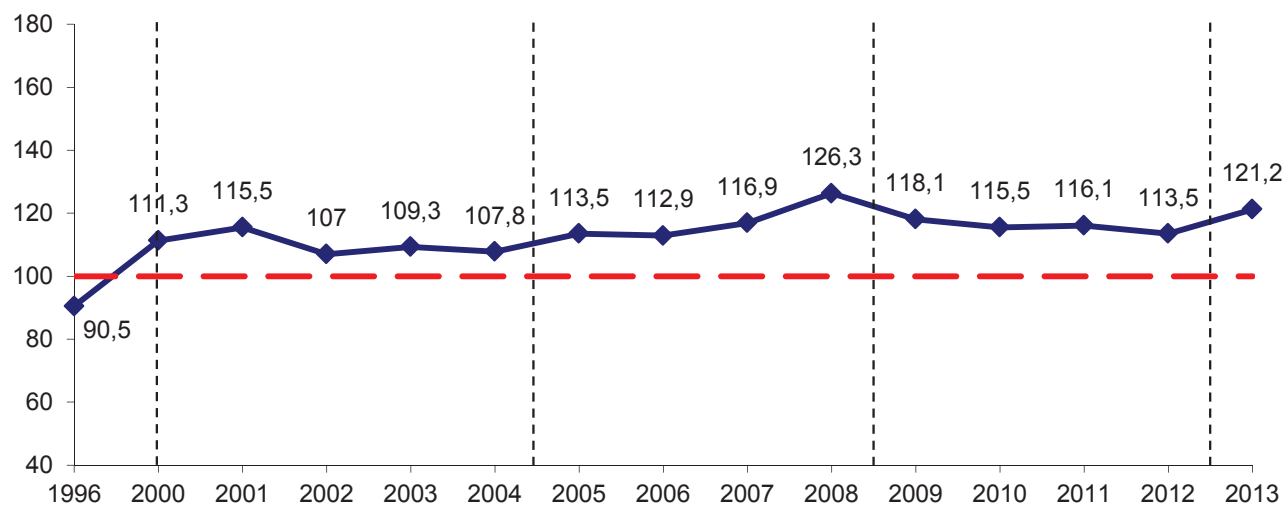

В 2013 г. заметно возрос уровень доверия жителей области к ФСБ (индекс увеличился со 114 до 121 п.). В период с 2009 по 2012 г. существенных изменений в динамике индекса не наблюдалось. 


\section{Отношение к деятельности Совета Федерации}

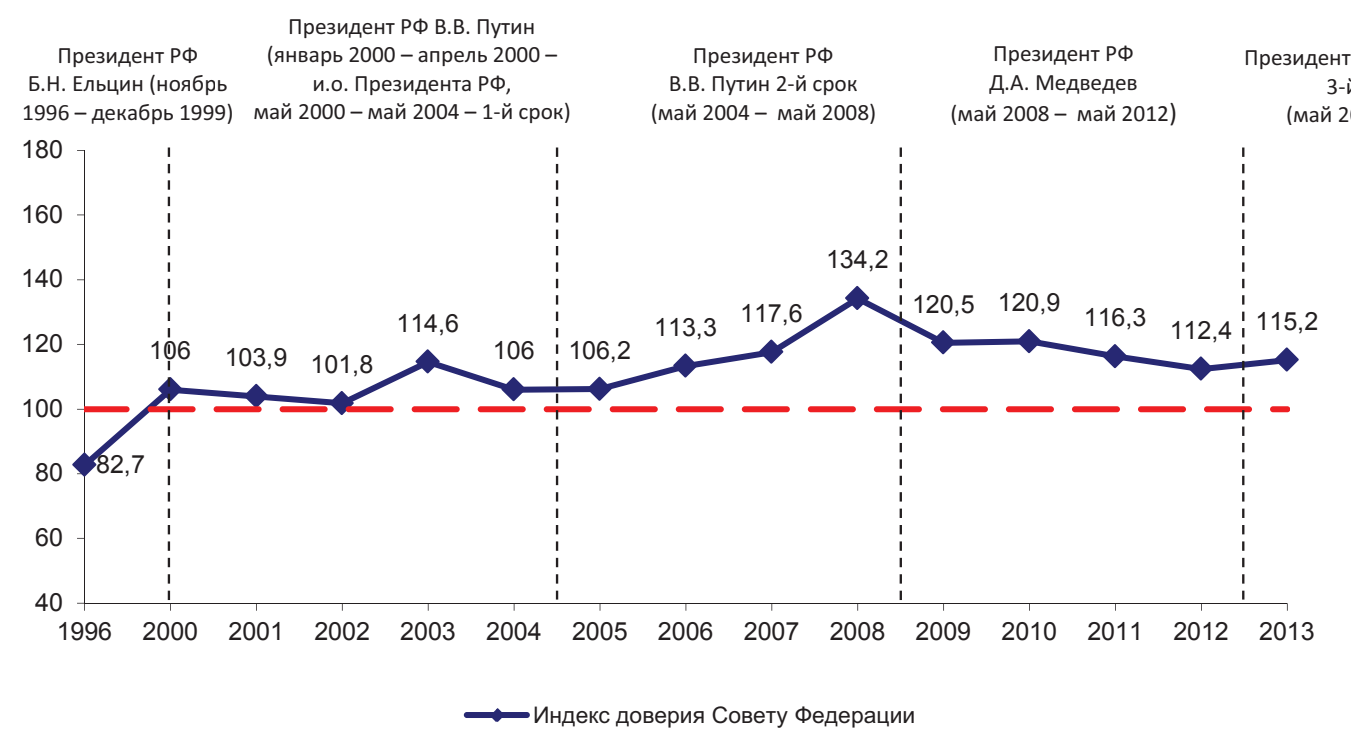

\section{Отношение к деятельности армии}

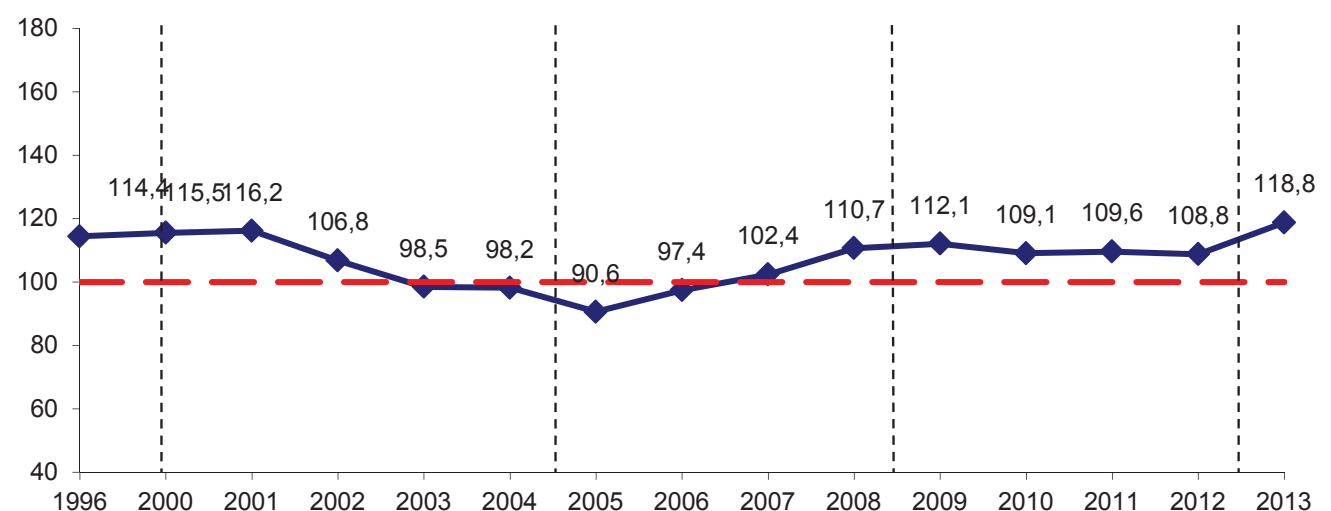

В 2013 г.

существенно увеличилось доверие населения к армии (индекс возрос со 109 до 119 п.). В период 2009-2012 гг. заметных изменений в динамике индекса не происходило.

\section{Отношение к деятельности Государственной Думы}

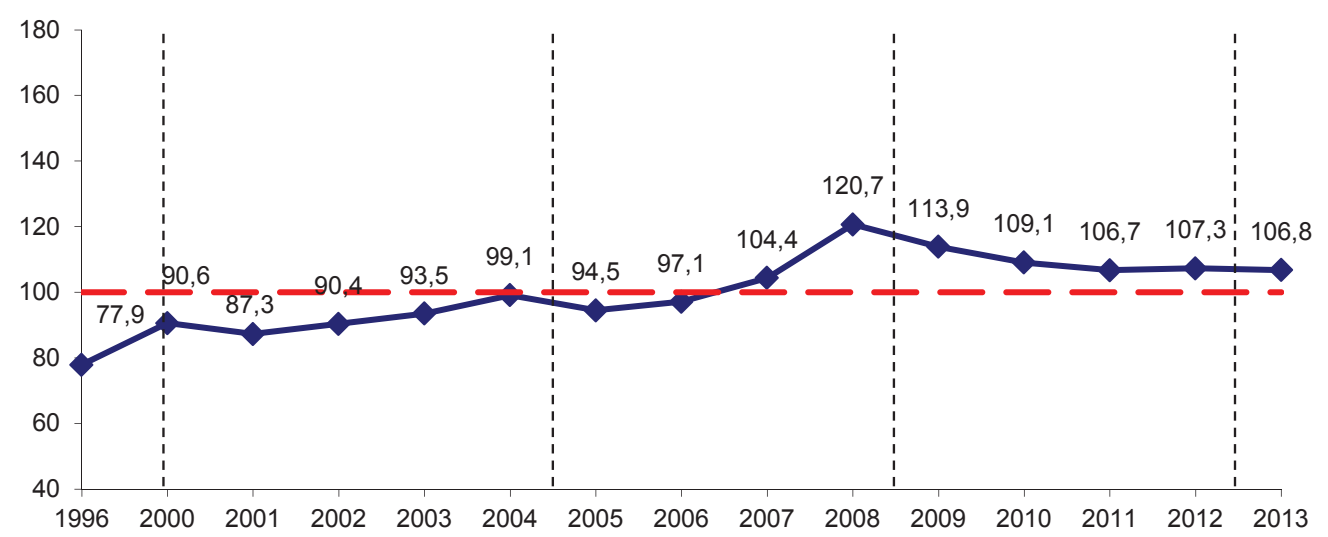

С 2011 г. не наблюдается существенных изменений в динамике индекса доверия Государственной Думе РФ (107 п.).

$\sim$ —Индекс доверия Государственной Думе 


\section{Отношение к деятельности СМИ}

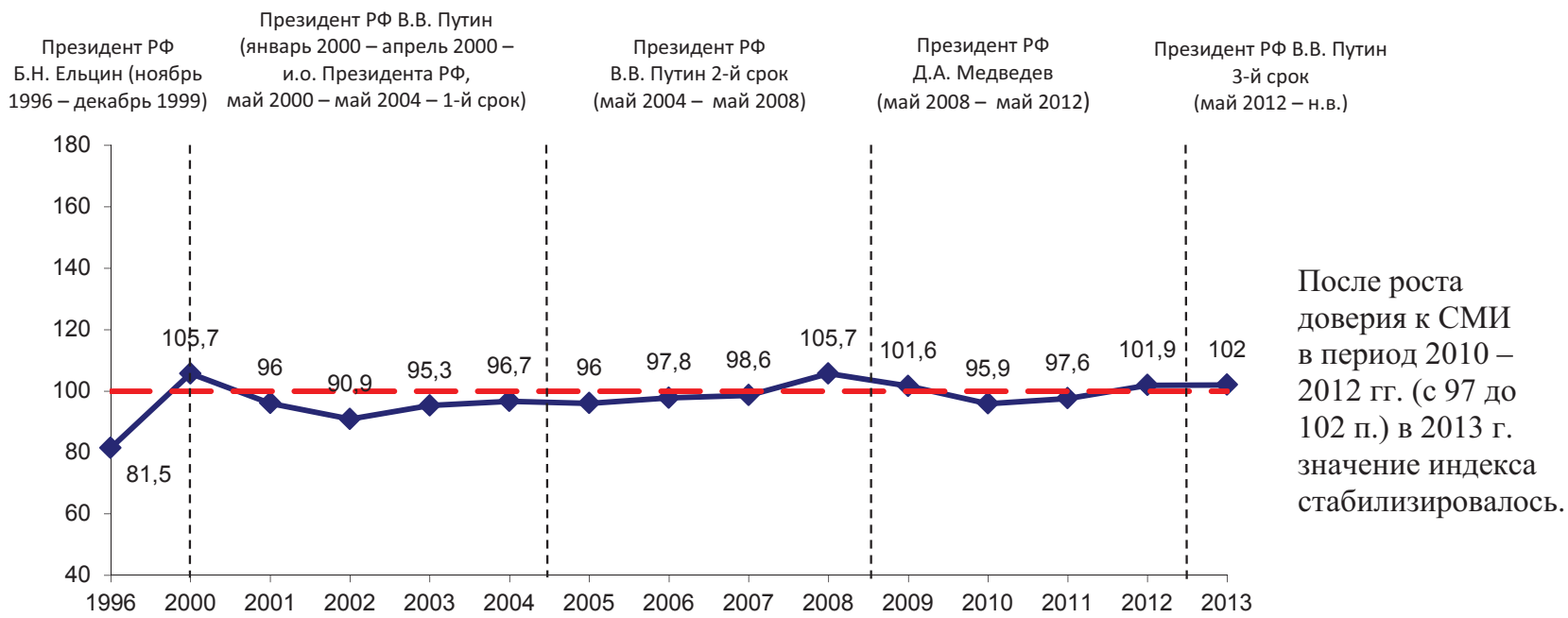

—Индекс доверия СМИ

\section{Отношение к деятельности полиции}

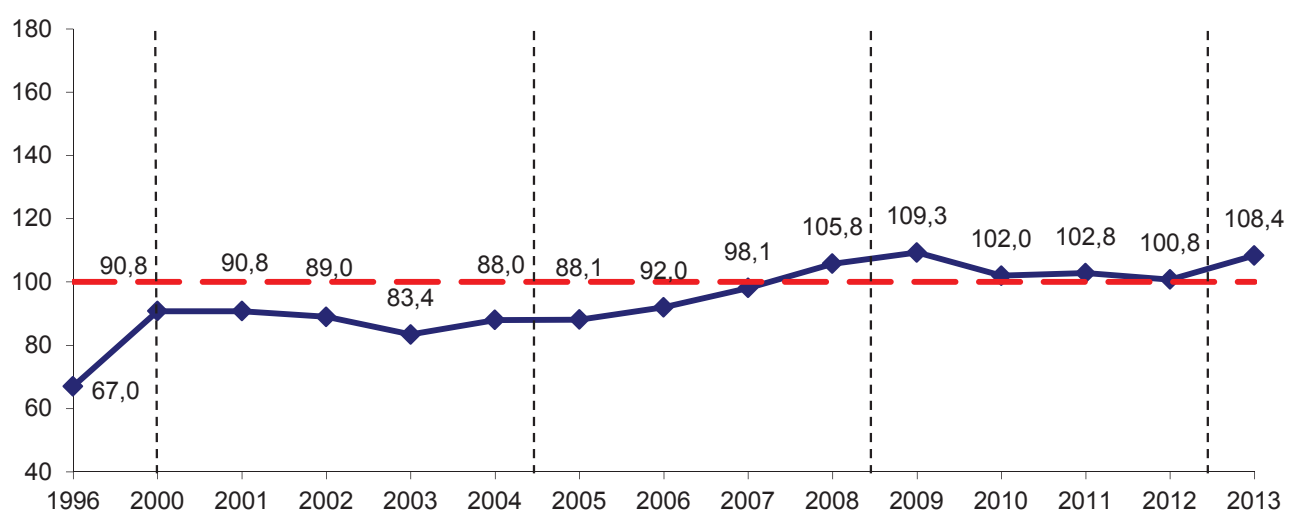

В 2013 г. возрос уровень доверия к полиции (индекс увеличился со 101 до 108 п.). В период с 2010 по 2012 г. существенных изменений не наблюдалось.

\section{Отношение к деятельности профсоюзов}

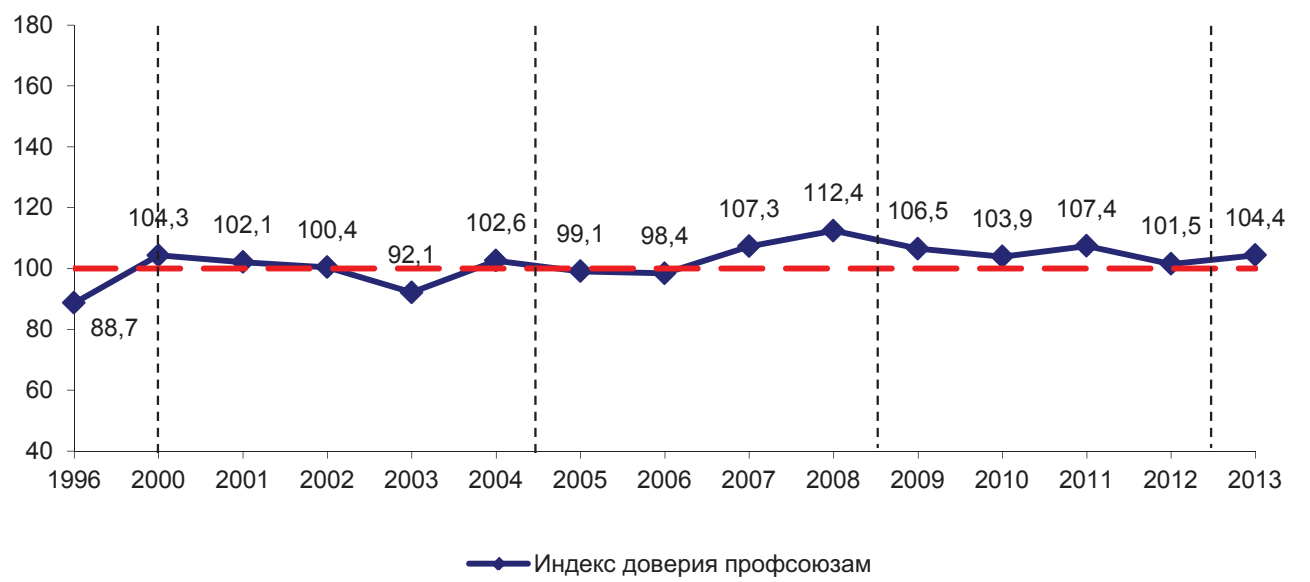

Индекс доверия к профсоюзам в 2013 г. незначительно увеличился (со 102 до 104 п.) после снижения в 2012 г. (со 107 до 102 п.). 


\section{Отношение к деятельности директоров, руководителей предприятий}

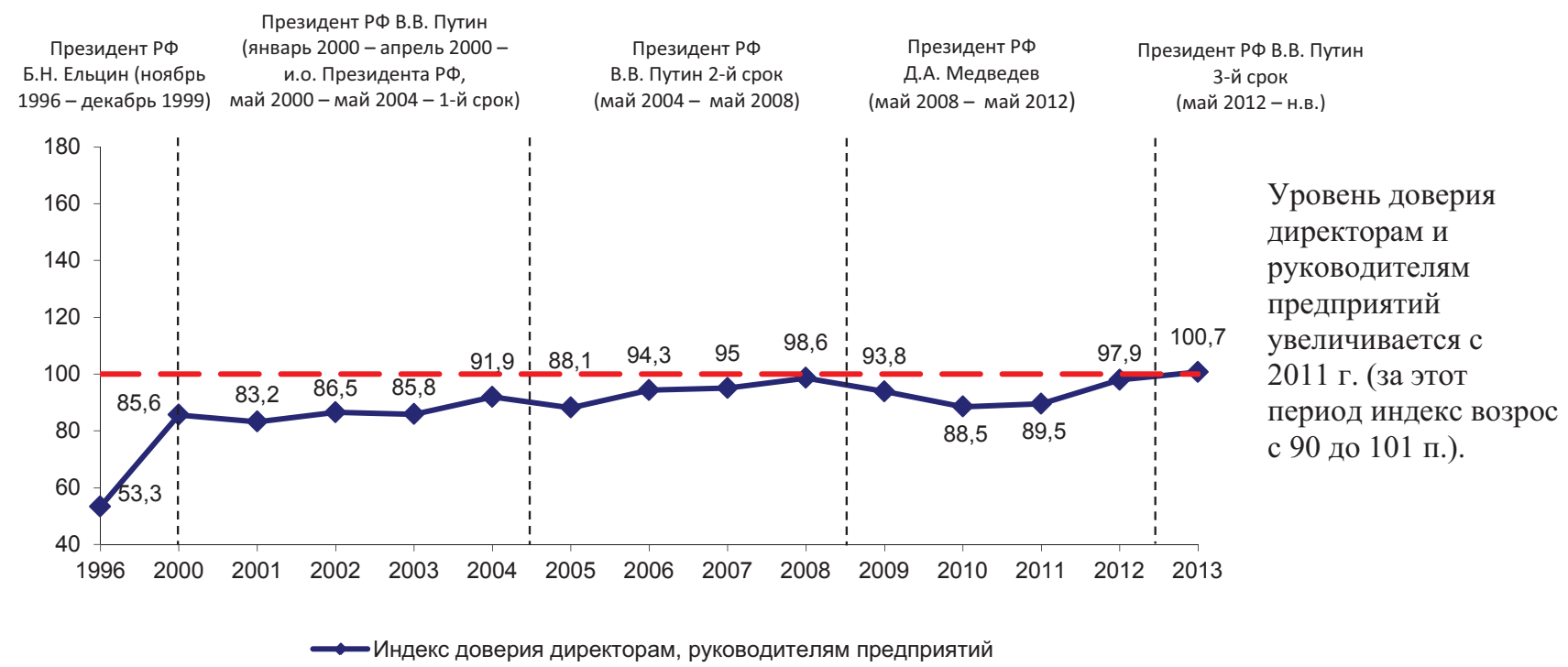

Отношение к деятельности банковских, предпринимательских кругов

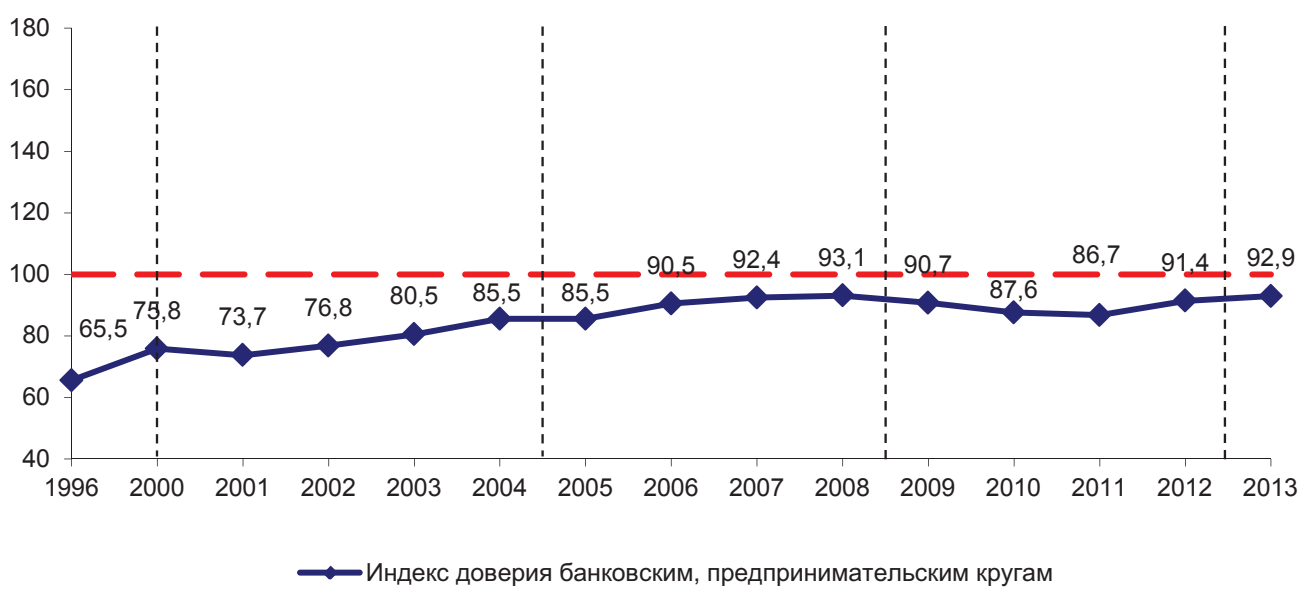

C 2011 г.

увеличивается индекс доверия банковским и предпринимательским кругам (за данный период с 87 до 93 п.).

\section{Отношение к деятельности политических партий, движений}

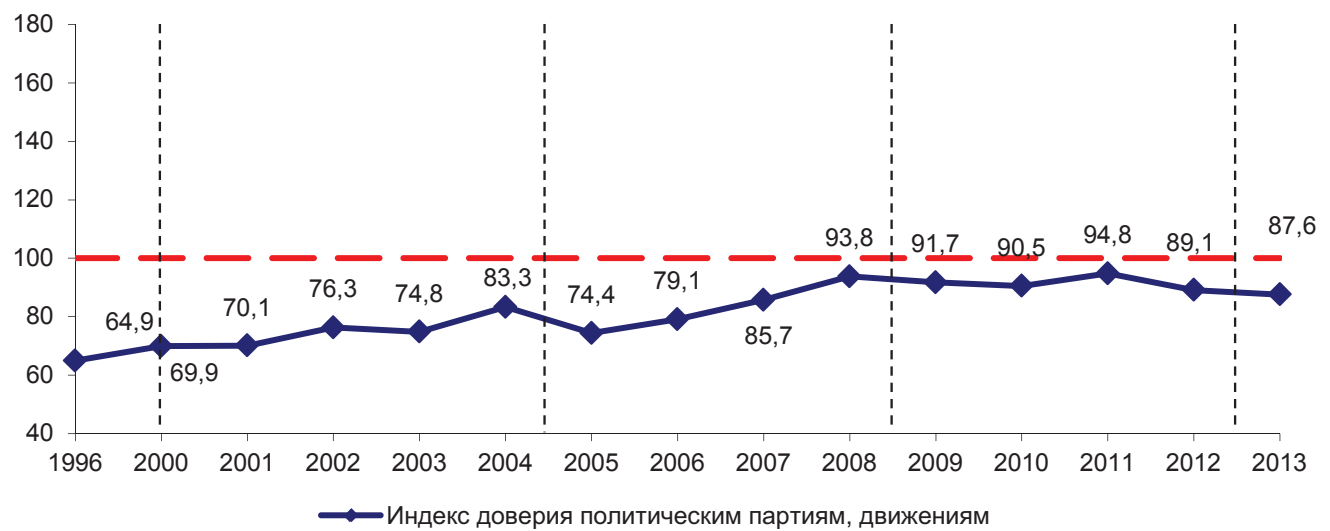

Экономические и социальные перемены: фракты, тенденции, прогноз 1 (31) 2014
Уровень доверия политическим партиям и движениям снижается с 2011 г. За этот период индекс уменьшился на 7 п. (с 95 до 88). 


\section{О ключевых задачах экономического развития России (по итогам Послания Президента РФ Федеральному Собранию)*}

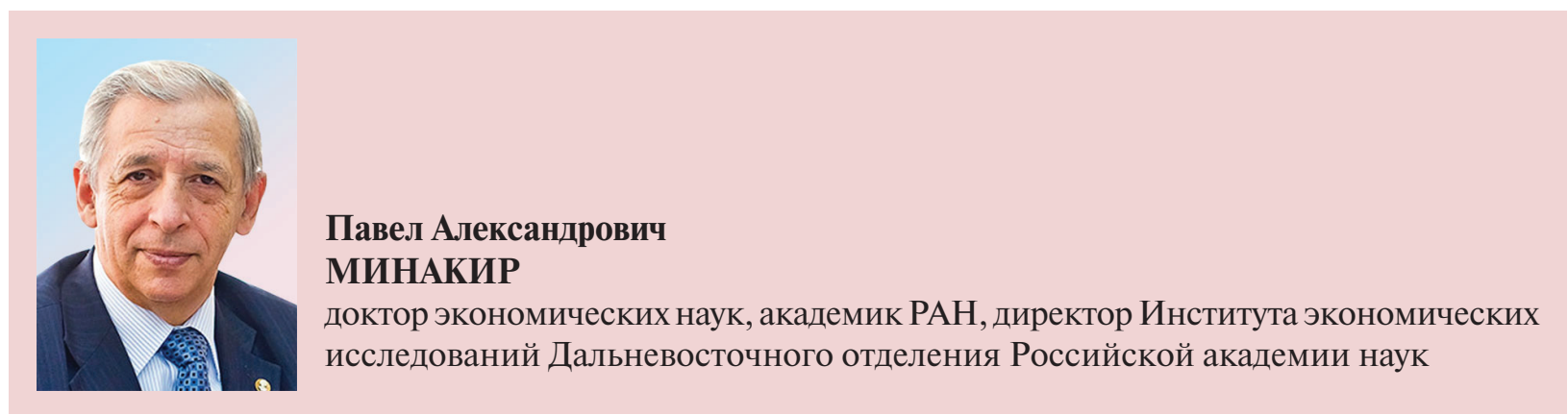

Прозвучало очередное Послание Президента РФ Федеральному Собранию. Как всегда, оно касалось всего спектра проблем и тенденций общественной жизни. Обстановка и в стране и в мире предельно сложная, а потому Послание не должно было стать дежурным политическим действом. От него логично было бы ожидать если не откровений, то, по крайней мере, адекватности в диагнозе, если не однозначности, то четкости в методах профилактики и лечения. Насколько оправдались ожидания? Остановимся только на двух сюжетах.

Сюжет первый - экономический рост, который самим Президентом назван «сердцевиной нашей (очевидно правительства и Администрации Президента?) работы» и базовым условием для решения задач социального развития.

Хорошей новостью можно считать то, что Президент указал на внутренние при- чины как на главный источник замедления роста, а если называть вещи своими именами, то начала масштабной экономической стагнации. Плохой новостью является то, как в Послании интерпретируются «внутренние причины».

Собственно говоря, названы две такие причины: 1) низкая производительность труда, 2) слишком высокая доля сырьевого экспорта. Из этого можно сделать вывод, что все остальные причины уже таковыми не являются, во всяком случае для правительства и Президента.

Что ж, возможно, публика и отдельные эксперты еще просто не заметили или не успели оценить того, что в России побеждена коррупция, демонтированы административные барьеры, обеспечена эффективная конкуренция, установлен контроль над функционированием госкорпораций, налажено государственное регулирование

* Представленная статья была опубликована (без заглавия) в журнале «Пространственная экономика» (№4 за 2013 год) в рубрике «От главного редактора». Перепечатывается по согласованию с автором. 
деятельности монополистов всяческого толка (естественных и противоестественных), реализована вменяемая денежнокредитная политика, налажен контроль над внешними заимствованиями (государственными и корпоративными), заменено «бюджетное правило» на правило оптимизации «незащищенных» бюджетных расходов, оптимизированы внешние капитальные потоки, решена проблема бюджетных навесов на региональном и муниципальном уровнях и устранена угроза субнациональных дефолтов, гарантированы права собственности, сформирована вменяемая промышленная политика и т.д. Это возможно, но неправдоподобно. Скорее, все вышеперечисленное столь многотрудно и конфликтно, что лучше было ограничиться предельно общими и оттого кажущимися очень правильными и логичными лозунгами.

Впрочем, повышение производительности труда - действительно важная тема. Следует лишь понимать, что сама производительность труда как отношение объема ВВП к численности занятых в экономике это не более чем индикатор, свидетельствующий о качестве труда, организации производственных процессов, состоянии технической структуры капитала, уровне технологии и пр. Низкий уровень производительности труда свидетельствует о том, что крайне низок уровень организации и технологии по всей цепочке экономических взаимосвязей и для всех экономических агентов.

В действительности проблема с индикатором результативности живого труда даже более серьезна, чем отражено в Послании. Президенту предоставили данные, согласно которым Россия входит в «Пятерку крупнейших экономик мира». Это действительно так, если судить по данным международных институтов за 2012 г. Правда, в пятерку Россия входит только по данным
Всемирного банка, а по данным МВФ и ЦРУ занимает 6-е место, но и это очень неплохо, хотя оценка ВВП различается почти на 800 млрд. долл. США ${ }^{1}$. Но следует учесть, что это данные, полученные при сопоставлении уровней ВВП, оцененных по паритету покупательной способности. А если сравнивать оценки номинального ВВП, да еще и на душу населения, что, собственно, и характеризует уровень экономического развития, то Россия сразу откатывается на скромное 50-е место между Литвой и Латвией. Конечно, если бы на каждого занятого производилось хотя бы в 2 раза больше ВВП по номинальной величине, то Россия подтянулась бы к Испании и Израилю, то есть на 30-32-е место 2.

Как же предлагается добиться этого светлого будущего? Президент предложил рецепт из четырех ингредиентов: повышение качества профессионального образования, создание гибкого рынка труда, благоприятный инвестиционный климат, современные технологии. В этом ничего удивительного и нового, конечно, нет. Есть нюансы. И удивительные.

Основа основ роста продуктивности живого труда - рост его технической и технологической вооруженности. А этого нельзя добиться без постоянной интродукции новых технических и технологических решений. Поэтому неудивительно, что свои поручения Президент начинает с поручения правительству и (вот это уже удивительно) Академии наук «провести корректировку перспективных направлений развития науки и техники». Ведь только что Академия наук была если и не уничтожена формально, то демонстративно унижена. У Академии наук фактически отобрано право определения направлений и перспектив научного

1 Список стран по ВВП (ППС). - URL: ru.wikipedia. org/wiki/ (дата обращения: 15.12.2013).

2 Список стран по ВВП (номинал) на душу населения. - URL: ru.wikipedia.org/wiki/ (дата обращения: 15.12.2013). 
и технологического поиска, а через два месяца после этого на академию возлагается задача определить путь технологического обновления. Может быть, это сделано по привычке? А может быть, обозначается будущий виноватый на случай (весьма вероятный) неудачи проекта «рывок производительности труда». Это было бы логично, ведь не правительство же ответит за провалы в экономике, ведь нехорошо, когда виноватого вообще нет, как, например, в случае с провалом «рывка ВВП».

Еще один нюанс - прикладные исследования, которые действительно являются ключевым пунктом в практических инновациях. Но при этом ни слова не сказано про ключевое звено в прикладных разработках - корпоративные разработки, центры, лаборатории, то есть про то, что ранее называлось «отраслевая наука». Подмена проблемы организации НИОКР и связи их с фундаментальными исследованиями проблемой патентов/лицензий и доходов от них не приближает к желаемому технологическому перевооружению. Страна может производить много патентов/лицензий, но использоваться они будут только при наличии спроса на вероятнее результаты их использования. Поэтому действительно нужно «формировать внутренний спрос на высокие технологии». Но почему только высокие технологии? А что, просто технологии нас уже не устраивают или с ними все обстоит благополучно?

Но предположим, что каким-то чудесным образом в условиях начавшегося развала фундаментальной науки, летаргического сна прикладных разработок, немотивированности отечественного бизнеса на реализацию стратегии модернизации, что требует в разы более высокой нормы накопления при отсутствии доступных кредитных источников, в России в разы же увеличилось количество собственных патентов и лицензий. Что произойдет с производительностью труда? Скорее всего, ничего. Потому что увеличение доли доходов от патентов и лицензий в стоимости ВВП означает лишь изменение структуры произведенного ВВП, да и то при условии, что отечественные патенты и лицензии востребованы рынком, то есть конкурентоспособны и на внутреннем, и на внешнем рынках. А еще потому, что невозможно базировать национальную экономику на собственных лишь патентах, реальная проблема - организация эффективного и непрерывного сплошного технологического заимствования. Но это требует изменения мотивации в экономике, изменения политики накопления, изменения целого ряда институтов, и отнюдь не одних только «институтов развития».

Второй сюжет связан со стратегическими целями экономического развития. В Послании в качестве примера таких целей приведена задача «подъема Сибири и Дальнего Востока», что названо рациональным проектом XXI в. Нельзя не согласиться, что «задачи, которые предстоит решить, беспрецедентны по масштабу ...и наши шаги должны быть нестандартными». Существуют в этой связи две проблемы, которые в тексте Послания явно не отражены.

Во-первых, остается большая неопределенность как раз с задачами, которые предстоит решить. Что это за задачи? Есть версии, но нет ясности. Это могут быть задачи ускорения темпов роста ВВП ria Дальнем Востоке и в Сибири. Это могут быть задачи увеличения объемов внешнеторгового оборота с восточными соседями. Это могут быть задачи создания «открытой экономики». Это могут быть задачи создания новой индустрии, задачи изменения структуры экономики. Это могут быть задачи создания комфортной среды обитания. И этот список можно продолжать довольно долго. От четкого и однозначного 
определения задачи зависит, как известно, и метод ее решения, и вероятный результат. Четкость и однозначность, однако, по-прежнему в дефиците.

Во-вторых, остается неопределенность как раз с «нестандартными шагами». Как следует из текста Послания, в качестве нестандартных решений имеется в виду создание сети «специальных территорий опережающего экономического развития с особыми условиями для организации несырьевых производств, ориентированных в том числе и на экспорт». Это уже весьма похоже на концепцию новой индустриализации в версии «модели экспортно-производственных дуг», проектов «ТОР-2030» и «ТОР-2050» ${ }^{3}$. Различие заключается в том, что упомянутые проекты предполагают специализацию в этих зонах на использовании технологических монополий, в том числе, и даже преимущественно, при переработке предназначенного для экспорта сырья и ориентированного на экспорт нового промышленного производства. В Послании такого акцента не делается, то есть предполагается, что предоставление налоговых льгот и обещание создания условий ведения бизнеса, конкурентных с ключевыми деловыми центрами АТР, - достаточные аргументы для переориентации отечественных и иностранных инвестиций в Восточную Сибирь и на Дальний Восток.

Это неявно предполагает, что государство готово взять на себя расходы по ком- пенсации не просто повышенных издержек на производство, но и таких «невидимых» статей, как, например, потери от низкого масштаба, повышенной капиталоемкости, увеличения уровня конкуренции. Если так, то тем более следовало бы ясно понимать, ради чего, ради какого экономического или военно-политического результата это делается.

Но даже если все это известно и объяснено, то все-таки нестандартными эти шаги назвать трудно. Это как раз весьма стандартные действия, которые должны учитывать главное - они дадут успех только в том случае, когда определены ключевые сравнительные преимущества подобных «зон». Такими преимуществами могут быть технологическое лидерство, изобилие и дешевизна ресурсов и/или факторов производства, масштаб рынка, преференциальная система институтов. Льготы налоговые могут и должны способствовать облегчению принятия решений по использованию этих преимуществ в том или ином месте.

Возможно, что краткость Послания не позволила развить продекларированные намерения по этим двум сюжетам и это будет сделано позднее. Хуже, если в этой краткости и схематичности изложенных намерений в очередной раз «зашита» уверенность в пресловутой «невидимой руке рынка», которая сама все расставит по местам. Тогда еще не раз придется обращаться к этим темам на уровне абстрактных идей и намерений.

\section{On the key tasks of Russia's economic development (following the Address of the RF President to the Federal Assembly)}

Minakir Pavel Aleksandrovich - Doctor of Economics, RAS Academician, Director of Economic Research Institute, Far Eastern Branch of RAS

3 См., напр.: Синтез научно-технических и экономических прогнозов: Тихоокеанская Россия - 2050. - Владивосток: Дальнаука, 2011. - 912 с; Тихоокеанская Россия - 2030: сценарное прогнозирование регионального развития. - Хабаровск: ДВО РАН, 2010. - 560 с; Минакир П.А. Экономика регионов. Дальний Восток. - М.: Экономика, 2006. $-848 \mathrm{c}$ 


\section{О стратегии интегрированной модернизации*}

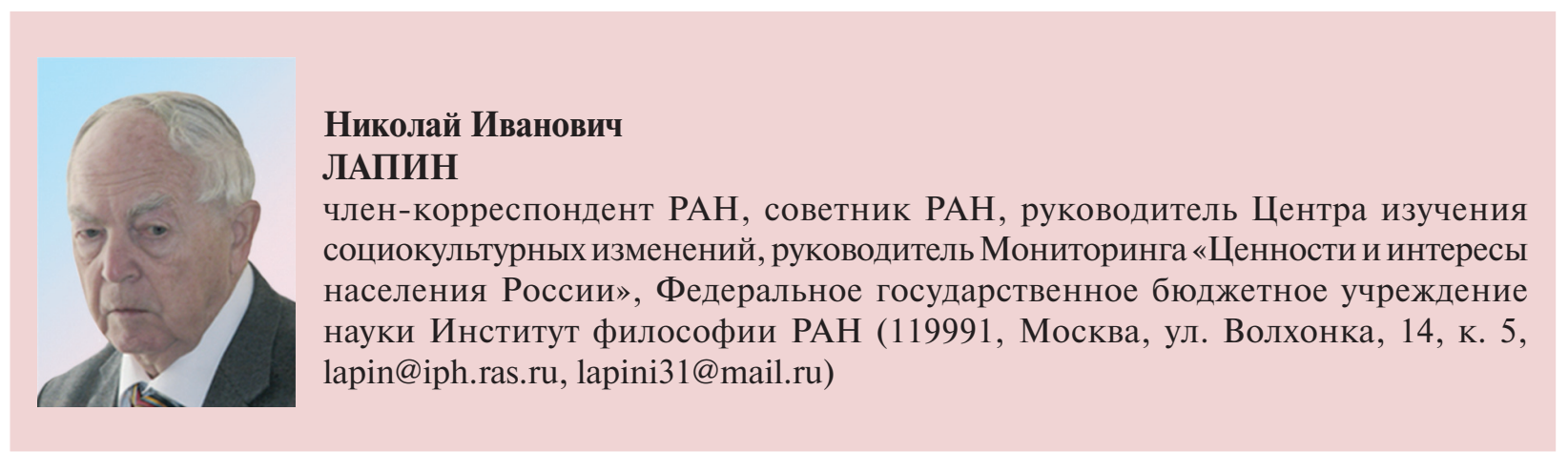

Аннотация. В статье продолжено конструирование стратегии модернизации России и ее регионов, первоначально изложенное автором в докладе на конференции «Эволюция регионов России и стратегии их социокультурной модернизации» (Вологда, ИСЭРТ РАН, октябрь 2012 г.; см. сб. материалов конференции, часть 1). Расширено значение понятия «интегрированная модернизация», предложенное профессором Хэ Чуаньци. Акцентировано внимание на незавершенности социетальной трансформации как главном ограничителе модернизации России и ее регионов. Обоснованы три этапа стратегии интегрированной модернизации, каждый из которых имеет свой набор стратегических приоритетов, который должен обеспечить взаимосвязь индустриальной и информационной стадий модернизации регионов соответствующих типов.

Ключевые слова: интегрированная модернизация, стратегия модернизации, этапы стратегии, стратегические приоритеты.

Lapin N.I.

\section{On the strategy of integrated modernization}

Lapin Nikolay Ivanovich - RAS Corresponding Member, RAS Councilor, Head of the Centre for the Study of Social and Cultural Change, Supervisor of the Monitoring "Values and Interests of Russia's Population", Federal State-Financed Scientific Institution the Institute of Philosophy, Russian Academy of Sciences (14, Volkhonka Street, building 5, Moscow, 119991, Russia (lapin@iph.ras.ru, lapini31@mail.ru).

* Статья подготовлена при финансовой поддержке РГНФ (грант № 14-03-00421a). 
Abstract. The article is continued designing strategy of modernization in Russia and its regions, originally set out by the author in the report at the Conference "The evolution of Russia's regions and their strategies of socio-cultural modernization» (Vologda, ISEDT RAS, October 2012; see. sat. Conference materials, part 1). Extended meaning of "integrated modernization", proposed by Professor Chuanqi He. Special attention is paid to the unfinished state of societal transformation as the main limit, modernization of Russia and its regions. Grounded three-phase strategy of integrated upgrades, each of which has its own set of strategic priorities, which should ensure the interaction of industrial and information stages of modernization of regions of the appropriate types.

Key words: integrated modernization, strategy of modernization, phases of strategy, strategic priorities.

Модернизация как всемирный процесс цивилизационных изменений. Ее структурные компоненты

В дискурсе о российской модернизации недостаточно учитывается историческая обусловленность модернизации как комплексного процесса цивилизационных изменений, который приобрел всемирный масштабㄹ. Разумные аргументы о нелинейности исторических процессов не тождественны отрицанию прогресса и его исторической обусловленности. Модернизация как раз и представляет собой последовательную (но не линейную: не с единственным стационарным состоянием, а с их потенциальным множеством) эволюцию человеческой цивилизации от аграрных обществ к индустриальным (первая стадия), затем к информационным (вторая стадия). Эта эволюция приобрела к XXI столетию всемирный характер, что свидетельствует о ее исторической закономерности.

Это комплексный процесс. В нем выделяются три главные компоненты, каждую из которых можно рассматривать как частичную, компонентную модернизацию.

1. Технико-технологическая модернизация - переход к новому технологическому укладу - новому способу создания

1 Подробнее см. [6, с. 32-49]. Ряд актуальных аспектов этой тематики был рассмотрен на российско-китайской конференции «Цивилизация и модернизация», которая состоялась в мае 2012 г. в Институте философии PAH (см. [8]). средств жизнедеятельности людей, который становится главным (более 50\%) источником валового внутреннего продукта страны, региона (ВВП, ВРП) или новым ресурсом для конкурентоспособного развития других обществ, государств. В начале информационной модернизации таким источником стал пятый технологический уклад (электронная промышленность, вычислительная техника), на смену которому приходит шестой уклад (нанотехнологии, клеточные технологии).

2. Социоэкономическая модернизация. С утверждением новых технологических укладов происходит последовательное изменение доли трех основных секторов экономики в ВВП: на первичной, индустриальной стадии модернизации резко снижается доля первичного, аграрного сектора вследствие соответствующего роста доли вторичного, индустриального сектора; на вторичной, информационной стадии значительно повышается доля третичного сектора (сфера услуг в широком смысле, в том числе производство, трансляция и использование новых знаний) и соответственно снижается доля первых двух секторов (материального производства). Изучив историю модернизации развитых стран Европы и Северной Америки за 200 лет, специалисты Центра исследований модернизации Академии наук Китая (ЦИМ АНК) выявили устойчивые показатели и включили их в инструментарий мониторинга всемирной модернизации, 
ежегодно осуществляемого с 2000 г., в качестве стандартных значений при получении индексов индустриальной модернизации [6, с. 59-60].

3. Социокультурная модернизация достижение достойных уровня и качества жизни людей, формирование и утверждение совокупности ценностей, в центре которых находится развитие человека как личности, его прав и свобод, а их утверждение в повседневной жизни обеспечивается социальной и иными структурами и институтами, такими как наука, образование, медицинское обслуживание, глубокая демократизация государственной и всей политической жизни общества, его судебно-правовых учреждений, обеспечение активности гражданского общества.

Bce компоненты модернизации как цивилизационного процесса взаимосвязаны. В совокупности они образуют интегрированную целостность. Если та или иная компонента представлена явно недостаточно, или, напротив, доминирует над остальными, то комплексная модернизация может превратиться в частичную квазимодернизацию.

Как показывает анализ опыта ежегодного мониторинга, осуществляемого ЦИМ АНК, показатели и индексы используемого инструментария достаточно убедительно представляют состояние, динамику и место каждой страны по социоэкономической компоненте модернизации, а также отчасти по социально-когнитивным ее показателям, тем самым в определенной мере и по модернизации в целом, дифференцируя ее на две стадии первичную (индустриальную) и вторичную (информационную), а также измеряя их интегрированный индекс. Вместе с тем социальные и когнитивные показатели и индексы лишь частично отражают ее социокультурную компоненту. А техникотехнологическая компонента представлена косвенно.
Таким образом, инструментарий ЦИМ АНК весьма полезен и мы будем использовать его. Но требуется полнее адаптировать его к особенностям России как модернизационно среднеразвитой страны, которая пережила деиндустриализацию и еше не завершила трансформацию в демократическое общество с социально ориентированной рыночной экономикой.

Обострение конкуренции стран за успехи модернизации

Согласно новейшим результатам мониторинга ЦИМ АНК, к 2010 г. 66 индустриально развитых стран на $100 \%$ осуществили первичную модернизацию, а с 1970-х годов 30 стран вступили во вторичную стадию всемирной модернизации. Из них 22 страны являлись информационно развитыми (их индекс составлял 80 и более баллов), а 26 стран - среднеразвитыми. Россия относилась к среднеразвитым странам (индекс 71 балл) и занимала 29 место. На пути к развитым странам впереди России находились 6 среднеразвитых: Греция, Чехия, Кувейт, Эстония, Италия, Португалия (от 72 до 79 баллов). Далее развитая Словения (82 балла). Наиболее развитой страной оставались США (109 баллов) [10, с. 71-74].

Перспективы всемирной модернизации во второй половине XXI столетия затронут более 190 стран (примерно 6 млрд. человек). К 2100 г., согласно прогнозным оценкам:

- стандарты вторичной модернизации 20 развитых стран будут в 5 раз выше, чем в 2005 г., а средний уровень модернизации в мире будет отставать от них на 50 лет;

- в условиях глобальной конкуренции позиция любой страны во всемирной модернизации может повыситься или снизиться, поэтому лидирующим странам следует постоянно защищать свои передовые позиции, а догоняющим - ускорять темп модернизации. 
Вывод: в XXI веке возрастет неравномерность модернизации стран, а конкуренция между странами будет жесткой [6, c. 230-234].

Что тормозит модернизацию России и что надо сделать, чтобы в условиях жесткой конкуренции сохранить и повысить модернизационный статус России и ее конкурентоспособность в мире?

Незавершенность социетальной трансформации - главная причина торможения модернизации России

По оценкам Т.И. Заславской, В.А. Ядова и ряда других российских ученых, социетальная трансформация (радикальное изменение всего общества), которая началась в результате системного кризиса и развала СССР в конце $80-$ х годов прошлого столетия, не завершилась: не достигла развитого состояния, которое обеспечивает конкурентоспособность в глобальном сообществе (см. [2, с. 104; 9, c. 8-11]).

Именно незавершенность социетальной трансформации составляет главную причину отставания России в процессе всемирной модернизации. Но незавершенность трансформации не означает, что вообще не возникло какое-либо новое общество. Что представляет собой современное российское общество, в чем состоят его главные характеристики?

Есть основания заключить, что возникло промежуточное транзитное состояние российского общества - симбиоз структур раннего капитализма с современной глобализацией: олигархо-бюрократический капитализм с компрадорской доминантой, которая подчиняет создаваемый в России капитал интересам транснационального бизнеса (подробнее см. [5, с. 337-340]). В результате отсутствует спрос на модернизацию российской экономики и всего общества, на еще немалый, хотя уже сниженный инновационный человеческий потенциал России, который гибнет втуне.

Материалы социокультурных портретов регионов, опирающиеся на социологические опросы населения, свидетельствуют о низкой человеческой эффективности процессов модернизации регионов, хотя статистически фиксируется инерционный рост ее социоэкономических индексов. Налицо социокультурно не сбалансированная квазимодернизация.

Такова цена упускаемых возможностей завершения социетальной трансформации. В условиях обострившейся международной конкуренции за успехи модернизации незавершенность трансформации приобрела характер стратегического порока эволюции современной России. Инерционному росту квазимодернизации следует противопоставить стратегию интегрированной, социокультурно сбалансированной, тем самым опережающей модернизации.

Завершение трансформации прежде всего должно стать ответом на две основные угрозы современной России, такие как:

1. Угроза безопасности, обостряющаяся из-за конфликтов в условиях глобальной нестабильности, требует срочно осуществить модернизацию оборонного комплекса страны и обеспечить ее конкурентоспособность на глобальных рынках.

2. Угроза политической неустойчивости и целостности страны вследствие возникших между тонким слоем сверхбогатых и массами новых бедных и нищих вопиющих имущественных контрастов, усугубляемых контрастами между уровнем жизни населения различных регионов, требует обеспечить повышение уровня и качества жизни населения всех регионов до среднеевропейского уровня. 
Стратегические тезисы и указы Президента России В.В. Путина

Объясняя причины своего согласия баллотироваться на выборах, кандидат в президенты России В.В. Путин в 2012 году писал: «Нашу задачу на предстоящих выборах вижу в том, чтобы убрать с дороги национального развития все то, что мешает нам идти вперед. Завершить создание в России (курсив мой. - Н.Л.) такой политической системы, такой структуры социальных гарантий и защиты граждан, такой модели экономики, которые вместе составят единый, живой, постоянно развивающийся и одновременно - устойчивый и стабильный, здоровый государственный организм. Способный безусловно гарантировать суверенитет России и процветание граждан нашей великой державы на десятилетия вперед. Отстоять справедливость и достоинство каждого человека. Правду и доверие в отношениях государства и общества» [7].

По сути, это призыв срочно действовать на основе таких базовых ценностей россиян, как справедливость, достоинство человека, самоценность его жизни.

Сразу после инаугурации Президент России В.В. Путин подписал Указ «О долгосрочной государственной экономической политике». В его первом пункте Правительству Российской Федерации поручено принять меры по «созданию и модернизации 25 млн. высокопроизводительных рабочих мест к 2020 году».

Такая задача - не красивая фраза, а насущная необходимость. Она обоснована статистическими данными. Многие социологические исследования, в том числе мониторинги ЦИСИ Института философии РАН «Ценности и интересы населения России» 2006 и 2010 годов, исследования более 20 научных коллективов по подготовке портретов регионов, показали, что задача создания миллионов новых рабочих мест устойчиво выдвигается населением России в 2006-2010 гг. на первое место. В условиях кризиса и последовавшей депрессии она стала еще более острой и должна быть конкретизирована в стратегиях и планах развития каждого региона. Нельзя допустить срыва ее выполнения.

Как преодолеть незавершенность социетальной трансформации России?

Комплексное завершение социетальной трансформации - сложнейшая историческая задача. Действия, направленные на ее решение, должны исходить прежде всего от высших органов государственной власти, осуществляться с активным участием структур бизнеса и гражданского общества. Однако важно не только то, кто действует, но и то, как осуществляются действия: от способа во многом зависит и состав участников. Успешными могут быть лишь их согласованные действия. Срочно необходим многосторонний переговорный процесс, инициированный Президентом России и нацеленный на такое согласование.

Основными участниками переговорного процесса должны стать власть собственники - гражданское общество. Очевидно, властные структуры должен возглавлять Президент России. Собственников должны представлять не только олигархи, но и Союз промышленников и предпринимателей, структуры малого бизнеса. Гражданское общество может быть представлено депутацией от федеральной и региональных общественных палат, а также от научных, образовательных и других структур.

Первый предмет таких переговоров меры по завершению социетальной трансформации России. Это должно быть открытое, публичное, вдумчивое обсуждение. Необходимо определить основные положения законопроектов и иных нор- 
мативных актов, направленных на достройку эффективных для всего общества экономических и политико-правовых институтов. В том числе необходимо:

- обеспечить повседневную защиту прав и свобод граждан (равенство перед законом и др.) судом и правоохранительными органами;

- законодательно закрепить социальную ответственность работодателей (предприятий, фирм) перед наемными работниками за достойный уровень их заработной платы, условия труда, пенсионное и иное социальное обеспечение, возможности участия в управлении организациями;

- законодательно запретить или серьезно ограничить вывод полученных в России доходов из-под российских юрисдикции и налогообложения;

- осуществить комплекс других мер (см. [3, с. 62-69; 9, с. 12-22]).

Достижение консенсуса относительно эффективных для всего общества экономических и политико-правовых институтов откроет возможности для решения второй задачи переговорного процесса разработки и осуществления стратегии интегрированной, опережающей модернизации как социокультурно сбалансированного цивилизационного процесса в России.

\section{Принципы разработки стратегии опере- жающей модернизации}

Чтобы успешно построить и осуществить стратегию опережающей модернизации, необходимо использовать принципы: 1) программно-проектного и 2) встречного, федерально-регионального ее конструирования.

В соответствии с предлагаемой стратегией, по заказам федеральных и региональных органов исполнительной власти, предстоит разработать программы и проекты модернизации объектов, в которых будут формулироваться конкретные проблемы/задачи социокультурно сбалансированного опережающего развития объектов и предлагаться способы их решения.

Важно обеспечить системный характер состава предлагаемых программ/проектов. Например, с помощью матрицы, в строках которой могут быть представлены основные уровни регулирования модернизируемых объектов, а в столбцах - стадии и состояния (типы) модернизированности регионов, соответствующие программы и проекты.

Подготовка программ и проектов должна происходить на трех кластерах-уровнях встречного их конструирования. Верхний кластер-уровень - федерально-окружной, «сверху вниз». Нижний кластер-уровень местно-региональный, «снизу вверх» (в целях экономии времени он может быть задействован одновременно с верхним). Срединный кластер-уровень - интегративно-региональный. Результаты утверждаются региональными органами.

\section{Опережающий характер интегративной модернизации}

Цели модернизации достигаются тем успешнее, чем динамичнее совершаются ее процессы по сравнению с другими странами (регионами), прежде всего соседними. Поэтому опережение следует считать важным критерием успеха модернизации.

Для России в качестве первоочередной можно рассматривать задачу опережения тех шести среднеразвитых европейских стран, которые были названы выше. При оценке сроков такого опережения необходимо учитывать, что эти страны также стремятся к успехам модернизации и движутся вперед, конкурируя между собой и с Россией. Следовательно, Россия должна как можно раньше начать двигаться быстрее их, чтобы, например, к середине 2030-х годов догнать двадцатку развитых стран. 
Следующей станет гораздо более сложная задача: постепенно опережать модернизационно развитые страны двадцатки и стать вровень с такими странами, как Англия, Франция, Германия. Но для этого нужны совсем иные темпы движения, чем наблюдаемые ныне и ожидаемые в соответствии с инерционными трендами. Ясно, что речь идет не о разовом опережении-рывке или прорыве, а о длительном, поэтапном процессе остро конкурентной борьбы с другими странами за успехи модернизации.

Своя конкурентная логика может быть прослежена и между регионами. Регионы, различающиеся по состояниям (типам) модернизированности, нуждаются в различных приоритетах модернизационной политики (приоритетных объектах инвестиций, специализации налоговых стимулов, повышении и использовании человеческого потенциала). Эти приоритеты должны изменяться по мере перехода регионов из одного состояния (типа) модернизированности в другое. При этом каждый регион стремится сохранить и повысить свой статус. В начале региональной модернизации могут преобладать приоритеты реиндустриализации; по мере ее осуществления приоритеты будут сосредоточиваться на развитии информационной модернизации. При этом цивилизационно разные регионы будут различаться по векторам и темпам модернизации.

Этапы и приоритеты стратегии интегрированной модернизации, динамика численности регионов на разных этапах

Для России как модернизационно среднеразвитой страны интегрированная модернизация есть не только охарактеризованная выше целостность ее компонентов, но и одновременно взаимосвязь двух ее стадий ${ }^{2}$ Можно выделить три варианта такой взаимосвязи, или три комбинации стратегических приоритетов модернизации регионов; они образуют этапы стратегии интегрированной модернизации. Каждому этапу соответствует одна из трех пар состояний (типов) модернизированности регионов ${ }^{3}$.

Эman 1. Приоритеты: преимущественно стимулирование роста и развития реиндустриализации; регионы невысоких состояний индустриальной модернизированности (типы 1 и 2).

Эman 2. Приоритеты: содействие завершению реиндустриализации и одновременно переходу к информационной модернизации; регионы состояний транзитной модернизированности (типы 3 и 4).

Эman 3. Приоритеты: преимущественно стимулирование начала, роста и развития информационной модернизации; регионы состояний системной информационной модернизированности (типы 5 и 6).

Динамика численности регионов, соответствовавших этим этапам в 20002010 гг., представлена на рисунке.

Как видим, в 2000-2008 годах на треть уменьшилось число регионов, соответствовавших первому этапу, и почти удвоилось число регионов, соответствовавших второму и третьему этапам стратегии интегрированной модернизации. Однако высшему этапу 3 (продолжение и развитие вторичной модернизации, т.е. системная информационная модернизированность) соответствовали лишь 7 регионов. Темп увеличения численности регионов от низших этапов к более высоким составил в среднем два региона в год и затормозился. В 2008-2010 годах он стал близким к нулевому.

\footnotetext{
2 О гармоничном развитии этих стадий как интегрированной модернизации и ее измерении см. [6, с. 18-20, 64-66].

Ранее мы выделили 6 таких типов. См. [4, с. 22-24].
} 
Динамика численности регионов соответственно основным этапам стратегии интегрированной модернизации

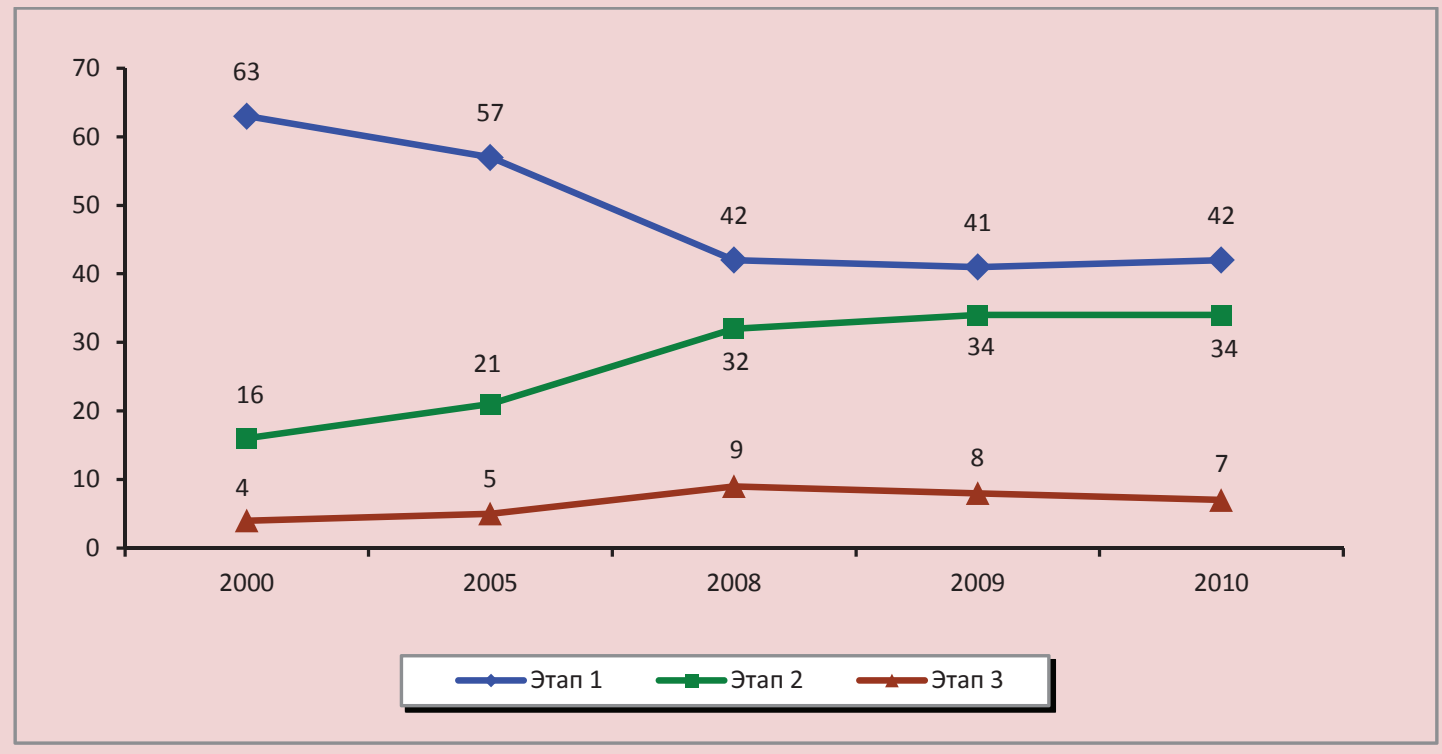

Источник: результаты расчетов с помощью Информационной системы «Модернизация» (ИСЭРТ РАН, 2013 г.).

Следовательно, при сохранении застоя, тем более - рецессии экономики дальнейший подъем регионов в более высокие модернизационные состояния становится весьма проблематичным.

Эти тренды подтверждают сделанные выше выводы о существовании заторможенного инерционного роста социоэкономической модернизации без социокультурного развития. России угрожает постепенное снижение модернизационного статуса и конкурентоспособности. Это наиболее вероятный путь страны вплоть до середины нынешнего столетия, если сохранится незавершенность её социетальной трансформации. Высокую вероятность такого пути подтверждают прогнозы российских историков и математиков, полученные с помощью расчетной многофакторной математической модели (см. [1, с. 143-144, 211]), и выводы Московского экономического форума (МГУ, март 2013 г.) [8, c. 8-11].

\section{Ожидаемые результаты стратегии опе- режающей модернизации}

Согласно нашим оценкам, при условии завершения к 2018 г. социетальной трансформации России и утверждения демократического общества с социально ориентированной рыночной экономикой, а также в результате осуществления стратегии интегрированной модернизации темпы подъема регионов от низших этапов к более высоким в ближайшие два десятилетия в среднем могут увеличиться в два-три раза. В исторически приемлемые сроки (к середине 30-х годов нынешнего столетия) около $80 \%$ российских регионов на $100 \%$ осуществят первичную модернизацию, а почти $50 \%$ регионов войдут в фазы начала и роста вторичной модернизации (повысят состояния модернизированности до типов 4, 5 и 6), приблизят качество жизни населения к среднеевропейскому уровню. К 2018 г. этого могут достичь около 20 регионов, к 2024 г. - до 25 регионов, 
к 2030 г. - около 35, а к 2036 г. - более 40 регионов. Из них около 20 регионов могут войти в состояния системной информационной модернизированности (типы 5 и 6).

K середине XXI столетия откроется простор для инноваций, интенсивного развития пятого и шестого технологических укладов, до среднеевропейского уровня повысится качество жизни населения большинства регионов, в основном сформируется комплексная модернизиро- ванность как новое цивилизационное качество российского общества. Действующими нормами станут такие ценности, как достоинство и равенство возможностей каждого человека, компетентность демократии и культура политической и деловой элиты, прозрачность административного и делового управления, высокие уровень и качество жизни населения. В итоге Россия утвердится в составе развитых стран мира, повысит свою привлекательность в Европе и Азии.

\section{Литература}

1. Акаев, А.А. Моделирование и прогнозирование экономического развития локальных цивилизаций / А.А. Акаев, А.И. Сарыгулов, В.Н. Соколов. - СПб.: Изд-во политехнического университета, 2011.

2. Заславская, Т.И. Социальные трансформации в России в эпоху глобальных изменений / Т.И. Заславская, В.А. Ядов // Социология и общество: пути взаимодействия: материалы пленарного заседания Всероссийского социологического конгресса / под ред. Г.В. Осипова, М.К. Горшкова. - М.: Вече, 2010.

3. Ильин, В.А. Влияние интересов собственников металлургических корпораций на социально-экономическое развитие: препринт / В.А. Ильин, А.И. Поварова, М.Ф. Сычев. - Вологда: ИСЭРТ РАН, 2012.

4. Лапин, Н.И. Модернизация в мире и в России. Состояния (типы) модернизированности российских регионов / Н.И. Лапин // Проблемы социокультурной модернизации регионов России / сост. и общ. ред. Н.И. Лапина, Л.А. Беляевой. - М.: Academia, 2013. - Гл. 1.

5. Лапин, Н.И. Через завершение трансформации - к интегрированной, социокультурно сбалансированной модернизации / Н.И. Лапин // Проблемы социокультурной модернизации регионов России / сост. и общ. ред. Н.И. Лапина, Л.А. Беляевой. - М.: Academia, 2013. - Гл. 22.

6. Обзорный доклад о модернизации в мире и Китае (2001-2010) / отв. ред. Хэ Чуаньци. - М.: Изд-во «Весь мир», 2011.

7. Путин, В.В. Россия сосредотачивается - вызовы, на которые мы должны ответить / В.В. Путин // Известия. - 2012. - 16 января.

8. Цивилизация и модернизация: материалы российско-китайской конференции, 29-31 мая 2012 г. / редкол.: Н.И. Лапин, Хэ Чуаньци и др. - М.: Институт философии РАН, 2012.

9. «Экономика для человека» - социально ориентированное развитие на основе реального сектора: итоговый документ Московского экономического формума, МГУ, 20-21 марта 2013 г. // Мир перемен. M., 2013. - №3.

10. The 1st International Modernization Forum: Modernization and Global Change. Proceedings. Beijing, 8 and 9 August 2013.

\section{References}

1. Akaev A.A., Sarygulov A.I., Sokolov V.N. Modelirovanie i prognozirovanie ekonomicheskogo razvitiya lokal'nykh tsivilizatsiy [Modeling and Forecast of Economic Development of Local Civilizations]. Saint Petersburg: Izd-vo politekhnicheskogo universiteta, 2011.

2. Zaslavskaya T.I., Yadov V.A. Sotsial'nye transformatsii v Rossii v epokhu global'nykh izmeneniy [Social Transformation in Russia in the Period of Global Changes]. Sotsiologiya i obshchestvo: puti vzaimodeystviya: materialy plenarnogo zasedaniya Vserossiyskogo sotsiologicheskogo kongressa [Sociology and Society: the Ways of Interaction: Proceedings of the Plenary Session of the All-Russian Congress of Sociology]. Ed. by G.V. Osipov, M.K. Gorshkov. Moscow: Veche, 2010. 
3. Ilyin V.A., Povarova A.I., Sychev M.F. Vliyanie interesov sobstvennikov metallurgicheskikh korporatsiy na sotsial'noekonomicheskoe razvitie: preprint [The Influence of the Interests of Metallurgical Enterprises' Owners on SocioEconomic Development: Preprint]. Vologda: ISERT RAN, 2012.

4. Lapin N.I. Modernizatsiya v mire i v Rossii. Sostoyaniya (tipy) modernizirovannosti rossiyskikh regionov [Modernization in the World and in Russia. Conditions (Types) of Modernization in Russia's Regions]. Problemy sotsiokul'turnoy modernizatsii regionov Rossii [Issues of Socio-Cultural Modernization of Russia's Regions]. Complied and edited by N.I. Lapin, L.A. Belyaeva. Moscow: Academia, 2013. Ch. 1.

5. Lapin N.I. Cherez zavershenie transformatsii - k integrirovannoy, sotsiokul'turno sbalansirovannoy modernizatsii [Through the Completion of Transformation to the Integrated, Socially and Culturally Balanced Modernization]. Problemy sotsiokul'turnoy modernizatsii regionov Rossii [Issues of Socio-Cultural Modernization of Russia's Regions]. Complied and edited by N.I. Lapin, L.A. Belyaeva. Moscow: Academia, 2013. Ch. 22.

6. Obzornyy doklad o modernizatsii v mire i Kitae (2001-2010) [A Review Report on the Modernization in the World and China (2001-2010)]. Executive Editor He Chuanqi. Moscow: "Ves' mir" Publ., 2011.

7. Putin V.V. Rossiya sosredotachivaetsya - vyzovy, na kotorye my dolzhny otvetit' [Russia Is Concentrating - the Challenges We Must Answer]. Izvestiya [Bulletin], 2012, January 16.

8. Tsivilizatsiya i modernizatsiya: materialy rossiysko-kitayskoy konferentsii, 29-31 maya $2012 \mathrm{~g}$. [Civilization and Modernization: Proceedings of the Russian-Chinese Conference, May 29-31, 2012]. Editorial Board: N.I. Lapin, He Chuanqi et al. Moscow: Institut filosofii RAN, 2012.

9. "Ekonomika dlya cheloveka" - sotsial'no orientirovannoe razvitie na osnove real'nogo sektora: itogovyy dokument Moskovskogo ekonomicheskogo formuma, MGU, 20-21 marta 2013 g. ["Economics for the People" - Socially Oriented Development on the Basis of the Real Sector: Outcome Document of the Moscow Economic Forum, MSU, March 20-21, 2013]. Mir peremen [World of Transformations]. Moscow, 2013, no.3.

10. The 1st International Modernization Forum: Modernization and Global Change. Proceedings. Beijing, 8 and 9 August 2013. 


\section{Государственное участие в экономическом развитии Арктики России: приватизация (исторический аспект)*}

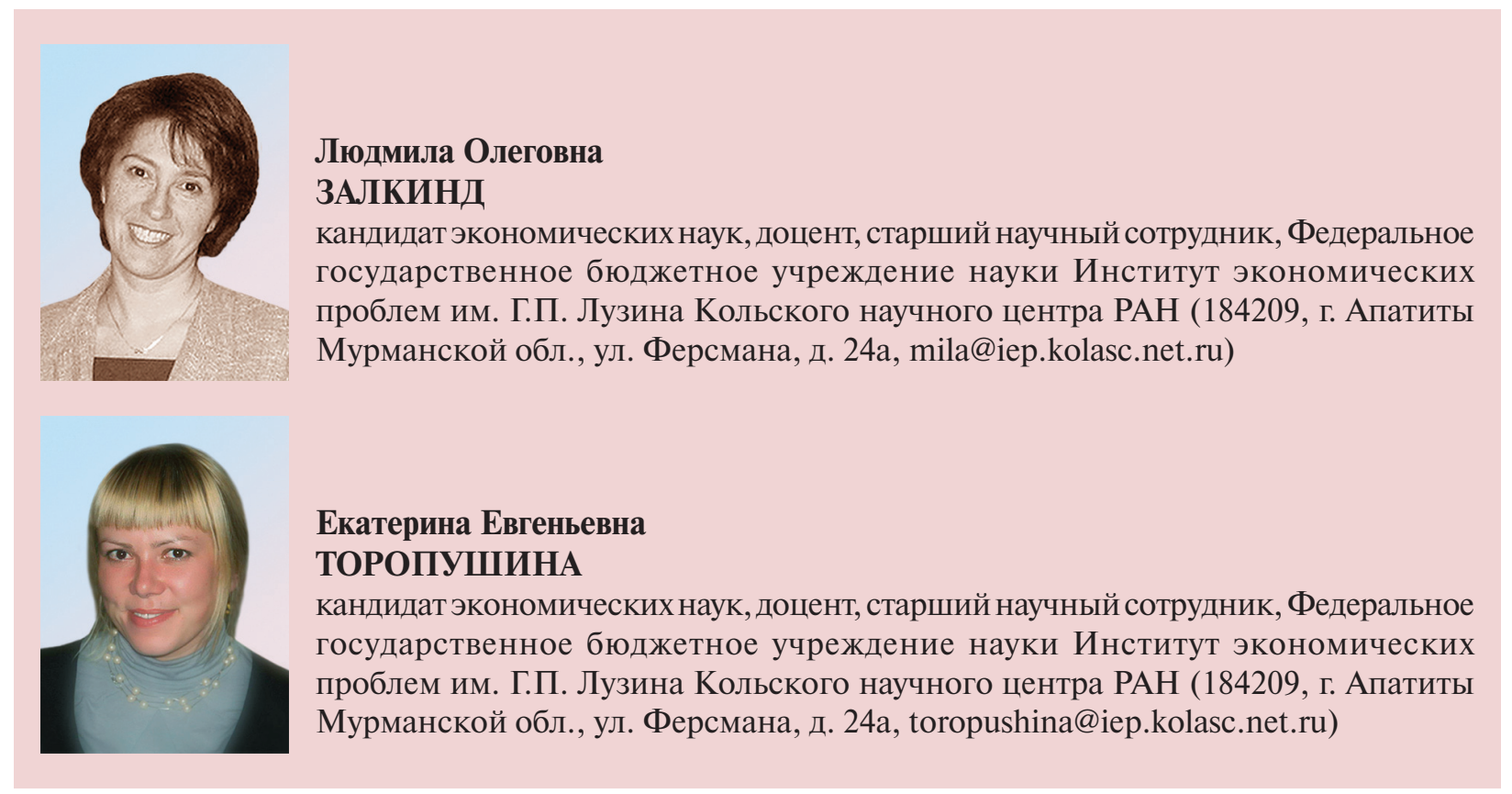

Аннотация. В статье рассмотрены процессы приватизации предприятий, происходившие в регионах Арктики РФ в период 1991-2010 гг., и их результаты. Рассмотрен аспект перераспределения влияния (финансового, политического и пр.) как между компаниями и государством, так и между разными уровнями власти. Сделан вывод об усилении в течение 2000-2010 гг. перехода от модели прямого, директивного вмешательства, когда государство ведет себя и как регулировщик, и как предприниматель, к принципам косвенного управления.

Ключевые слова: приватизация, Арктика, государственная политика, распределение собственности.

* Часть результатов получена в рамках выполнения проекта №12-32-06001 «Российская Арктика: современная парадигма развития» на 2012-2014 гг, грант целевого конкурса Российского гуманитарного научного фонда (РГНФ) «Россия в Арктике: история, современность, перспективы». 
Zalkind L.O., Toropushina E.E.

\section{Participation of the state in the economic development of Russia's Arctic: privatization (historical aspect)}

Zalkind Lyudmila Olegovna - Ph.D. in Economics, Associate Professor, Chief Research Associate, Federal State-Financed Scientific Institution G.P. Luzin Institute of Economic Problems of Kola Scientific Centre of the Russian Academy of Sciences (24A, Fersman Street, Apatity, Murmansk Oblast, 184209, Russia, mila@iep.kolasc.net.ru)

Toropushina Ekaterina Evgen'evna - Ph.D. in Economics, Associate Professor, Chief Research Associate, G.P. Luzin Institute of Economic Problems of Kola Scientific Centre of the Russian Academy of Sciences (24A, Fersman Street, Apatity, Murmansk Oblast, 184209, Russia, toropushina@iep.kolasc.net.ru)

Abstract. The article considers the processes and results of privatization of enterprises taking place in the Arctic regions of the Russian Federation in the period of 1991-2010. The authors study the aspect concerning the redistribution of influence (financial, political, etc.) between companies and the state, and between different levels of power. A conclusion has been made that the 2000-2010 period faced the intensification of transition from the direct intervention model, when the government acts as a regulator and entrepreneur, to the principles of indirect management.

Key words: privatization, Arctic, state policy, distribution of property.

Движущей силой государственной политики России (как в XIX, так и в начале XX века) относительно северных и арктических территорий являлась необходимость защиты национальных интересов. Угрозой для России было стремление ряда стран взять под контроль промысловые богатства арктических архипелагов, пользуясь отсутствием её внимания к своим заполярным владениям. Однако государственная политика была непоследовательна и нецеленаправленна.

Это происходило из-за того, что важнейшие стратегические интересы России касались запада и юга, а не севера. Хотя на протяжении XX века население арктических регионов ${ }^{1}$ возрастало (табл. 1) и

1 В статье проведен анализ процессов приватизации, происходивших в следующих регионах Арктики России: республиках Карелия, Коми и Саха (Якутия), Архангельской, Магаданской и Мурманской областях, Ненецком, Ханты-Мансийском, Чукотском и Ямало-Ненецком автономных округах, Таймырском (Долгано-Ненецком) и Эвенкийском районах Красноярского края. только в самом конце XX века начало снижаться. Тенденция снижения численности населения продолжается и сейчас.

С середины 1930-х гг. государственная политика в Арктике перешла на качественно иной уровень. Начинается государственное регулирование процессов изучения и освоения территории.

Таблица 1. Численность населения регионов Арктики РФ

\begin{tabular}{|c|c|}
\hline Год & \multicolumn{1}{|c|}{$\begin{array}{c}\text { Численность населения, } \\
\text { млн. чел. }\end{array}$} \\
\hline 1926 & 1,7 \\
\hline 1939 & 2,9 \\
\hline 1959 & 4,3 \\
\hline 1967 & 5,2 \\
\hline 1979 & 6,4 \\
\hline 1989 & 8,3 \\
\hline 1995 & 7,9 \\
\hline 2002 & 7,2 \\
\hline 2010 & 6,9 \\
\hline \multicolumn{2}{|l}{ Источник: данные Bcepoccийских переписей населения } \\
$\begin{array}{l}\text { 1926, 1939, 1959, 1979, 1989, 2002, 2010 гг. [Эл. ресурс] // } \\
\text { Росстат. - URL: http://www.gks.ru }\end{array}$ \\
\hline
\end{tabular}


Движущей силой этих процессов явилось стремление использовать природные ресурсы для развития национальной экономики. В 1933-1935 гг. вопросы изучения, освоения и колонизации архипелагов акватории Баренцева моря были переданы в ведение Главного управления Севморпути, руководство этими процессами стало централизованным.

Советское масштабное индустриальное развитие Арктики было высокозатратным. Геополитические интересы централизованного государства часто доминировали над экономическими. Высокие издержки развития Арктики длительное время нейтрализовывались дешевой рабочей силой. Быстрое пионерное освоение этих территорий в 1930-е гг. было обеспечено организациями «Печлаг», «Норильлаг», «Дальстрой» и др., которые активно использовали труд заключенных ГУЛАГа.

В позднесоветский период развитие Арктики было обеспечено государственными ведомствами - системой мощных, управляемых из центра отраслевых объединений. Высокие издержки развития компенсировались обширными перераспределениями нефтегазовой ренты, которые позволили (вопреки требованиям экономической целесообразности) дотировать цены, транспортные и энергетические тарифы, устанавливать щедрые льготы и гарантии жителям и пр.
Сохранение контроля над арктическими территориями обеспечивалось режимом жесткой принудительной централизации, директивным государственным управлением.

До 1991 г. практически все предприятия страны находились в государственной собственности, за исключением собственности кооперативных предприятий, составлявшей не более 5\%. В 1991 г. федеральное правительство инициировало начало передачи предприятий из государственной в частную собственность, в связи с чем в 1991-1992 гг. издан ряд нормативных актов [1, 3, 8, 12, 13], регулировавших этот процесс.

Первым этапом приватизации стало разделение единой государственной собственности по разным уровням [11, 15], при этом исключительно к федеральному уровню были отнесены военные предприятия и объекты, обеспечивавшие безопасность страны и других отраслей экономики (транспортная и энергетическая инфраструктура), крупные комбинаты, вузы, крупные поставщики коммунальных услуг, сельскохозяйственные предприятия и т.п. То есть практически все предприятия Арктики стали федеральной собственностью (табл. 2). Региональная собственность формировалась по остаточному принципу, и ее объем зависел от решений федеральной власти.

Таблица 2. Распределение предприятий регионов Арктики по формам собственности, \%

\begin{tabular}{|c|c|c|c|c|}
\hline \multirow{2}{*}{ Форма собственности } & \multicolumn{4}{|c|}{ Год } \\
\hline & $1996^{*}$ & 1999 & 2008 & $2010^{* *}$ \\
\hline Государственная & 30,6 & 7,1 & 5,8 & 4,6 \\
\hline Муниципальная & 24,0 & 8,1 & 9,3 & 8,4 \\
\hline Частная & 6,8 & 68,4 & 74,5 & 79,1 \\
\hline Некоммерческая & 0,2 & 7,2 & 6,4 & 4,7 \\
\hline Смешанная & 38,4 & 9,3 & 4,0 & 3,1 \\
\hline
\end{tabular}


На муниципальный уровень были переданы предприятия ЖКХ, торговли, объекты здравоохранения, культуры и пр. Таким образом, в арктических регионах основная собственность оказалась распределенной между федеральным и муниципальным уровнями. В результате муниципалитеты получили как высоколиквидную собственность - магазины и бытовое обслуживание, так и малоликвидную - коммунальные службы, больницы, требующие больших вложений.

В региональную собственность, как правило, передавались лишь второстепенные предприятия. Так, в Магаданской области к 1993 г. в собственность региона было передано всего 45\% от общего числа предприятий, которые потенциально могли быть переданы на региональный уровень. Ни одно предприятие, играющее значимую роль в экономике региона, не стало региональным [31]. Все 40 горнодобывающих предприятий региона, формирующие его экономику, перешли в разряд федеральных. Такое разграничение собственности позволяло сохранять зависимость регионов от центра.

Вторым этапом приватизации стал процесс «малой» приватизации и преобразования крупных и средних предприятий в акционерные общества. «Малой» приватизацией назывался процесс приватизации муниципальных предприятий: магазинов, кафе, парикмахерских и т.п. Этот процесс начался в 1992 г. и прошел свой пик в 19921993 гг. (после 1994 г. сдерживался законодательно [6]). Но уже к 1996 г. эти объекты были в основном приватизированы. Преимущественно использовавшимся методом «малой» приватизации являлась продажа предприятий на специальных аукционах ${ }^{2}$, часть муниципальной собственности была преобразована в акционерные общества [21].

2 Аукционы проводились с учетом преимущественных прав трудового коллектива предприятия на его выкуп.
Процесс «малой» приватизации в регионах Арктики начался достаточно бурно. Так, в Магаданской области в 1992 г. приватизировано 35 объектов муниципальной собственности (в основном это магазины и предприятия бытового обслуживания), в 1993 г. - 250, в $1994-75,1995$ - 69 объектов (к 1996 г. большинство их стали частными).

В Мурманской области этот процесс имел другие темпы. Хотя программой приватизации намечалось приватизировать в 1992 г. 524 таких предприятия, было приватизировано лишь 126, в 1993 г. - 109.

Муниципалитеты, да и сами работники этих предприятий, старались избежать приватизации. Со стороны муниципалитетов это было обусловлено желанием сохранить доходную базу, поскольку в процессе приватизации вместе с предприятиями они ее теряли. Для работников выход на свободный рынок требовал маркетинговых усилий. Пребывание же предприятия в статусе муниципального гарантировало минимальную заработную плату и возможность быть убыточным. В итоге к середине 1997 г. в Мурманской области было приватизировано лишь 406 муниципальных предприятий [21].

Таким образом, приватизация муниципальных предприятий прошла хотя и не полностью, но достаточно быстро. Значительная часть (60-70\%) предприятий оптовой и розничной торговли, бытового обслуживания и общественного питания стали частными [35].

В результате малой приватизации появился малый бизнес. В 1994 г. количество малых предприятий в Арктике превысило 30 тыс. Затем, к 1998 г., в ходе процесса ликвидации убыточных предприятий количество предприятий малого бизнеса уменьшилось на треть. И только к 2006 г. объем малого бизнеса восстановился и превысил уровень 1994 г. Количество малых предприятий в 2010 г. составляло уже около 65 тыс. 
Предприятия, относившиеся к государственной собственности (и региональной, и федеральной), до начала приватизации преобразовывались в акционерные общества. В регионах Арктики за период 1993-1999 гг. было акционировано около 1500 государственных предприятий, за 2000-2010 гг. - более 300 .

Процесс акционирования происходил скачкообразно. Так, в Магаданской области в 1993-1994 гг. в акционерные общества было преобразовано 111 предприятий федеральной и региональной собственности, что составляло не более $15 \%$ всех предприятий [31]. Большая часть предприятий прошли процесс акционирования в 1996 г. (табл. 3). В 1998-2001 гг. наблюдался спад процесса акционирования. Но к концу 2000-х гг. все крупные и средние предприятия федеральной и региональной собственности, подлежавшие приватизации, стали акционерными обществами.

Всего за 1992-1996 гг. было образовано 152 акционерных общества. В этот период были акционированы все крупные предприятия, являющиеся основой экономики региона.

Таблица 3. Количество акционерных обществ в регионах Арктики РФ, созданных из государственных и муниципальных предприятий

\begin{tabular}{|c|c|}
\hline Год & Количество А0, нарастающим итогом \\
\hline 1993 & 552 \\
\hline 1995 & 1359 \\
\hline 1997 & 1546 \\
\hline 1999 & 1593 \\
\hline 2001 & 1607 \\
\hline 2003 & 1642 \\
\hline 2005 & 1783 \\
\hline 2007 & 1848 \\
\hline 2009 & 1920 \\
\hline 2011 & 1958 \\
\hline Источник: рассчитано по данным Росстата [Эл. ресурс]. - \\
URL: http://www.gks.ru \\
\hline
\end{tabular}

Затем до середины 2000-х гг. процесс замер, а далее продолжился за счет преобразования в акционерные общества государственных унитарных предприятий ${ }^{3}$.

Третий этап приватизации заключался в размещении акций приватизируемых предприятий. В 1992-1996 гг. часть акций бесплатно передавалась работникам этих предприятий, оставшуюся часть акций государственный фонд имушества продавал на аукционах либо оставлял как закрепленный государственный пакет.

В период акционирования было введено понятие «золотая акция» - это акция, которая на определенный период времени ${ }^{4}$ дает государственному органу решающий голос на акционерном собрании. В 1995 г. на 28\% приватизированных в этом году предприятий Арктики государство сохранило за собой контроль в форме контрольного пакета и/или «золотой акции» [35]. В среднем процесс акционирования и перехода из государственной в смешанную, а затем в частную форму собственности занимал 3-4 года.

Региональные власти могли сохранять свое влияние не только в случае наличия прямого контроля. Например, в 1998 г. владельцы предприятий «Североникель» и «Печенганикель» ${ }^{5}$ были намерены их закрыть из-за плохой экономической конъюнктуры на мировом рынке никеля. Региональная власть активно вмешалась в ситуацию, и под ее давлением была создана новая компания - ОАО «Кольская ГМК»,

3 Основную часть этих предприятий составляли «стратегически важные» (предприятия ВПК, НИИ, в том числе военной направленности, транспортные предприятия, нефтяные и газовые компании) [10].

4 Вначале «золотая акция» имела период действия три года, затем сроки были увеличены вплоть до настоящего времени [7].

5 Предприятия являлись градообразующими, и их закрытие грозило закрытием расположенных рядом поселений и массовой безработицей - около 30 тыс. человек. 
эффективно работающая и по настоящее время. Региональная власть использовала косвенные рычаги влияния ${ }^{6}$ на владельцев компании.

Сложное положение предприятий после приватизации зачастую являлось основанием для вмешательства государства. В 1996 г. государство вернуло себе $25 \%$ акций одного из крупнейших предприятий Мурманской области - ОАО «Ковдорский ГОК» (по постановлению суда, за невыполнение инвестиционных условий приватизации) [22]. Предприятие находилось на грани банкротства. В начале 1997 года были возвращены (в рамках досудебного урегулирования) в муниципальную собственность г. Мурманска 21\% акций ГОКа. Т.е. под контролем регионального правительства оказалось $46 \%$ акций, что обеспечивало полный контроль над предприятием, поскольку другой значительный пакет, составлявший около 30\%, был распылен между работниками ГОКа. Региональному правительству удалось стабилизировать работу предприятия, наладить сбыт продукции и к 1999 г. вывести комбинат на 30 млн. руб. прибыли в год. В 2001 г. было принято решение о продаже государственного и муниципального пакета акций. Владельцем ОАО «Ковдорский ГОК» стала частная компания ОАО «МХК Еврохим».

В то же время региональные власти пытались сохранить влияние на расположенные на их территории предприятия. Это обусловлено тем, что в большинстве арктических регионов активы предпри-

\footnotetext{
6 Мы можем только предполагать, каким образом региональная власть воздействовала на владельцев. Несомненно, что она апеллировала к федеральным властям и получила их поддержку. Фактически владельцы предложили региональной власти самой «спасать» эти предприятия, предоставив им полную самостоятельность. При создании ОАО «Кольская ГМК» акции были распределены следующим образом: 50\% принадлежало АО «Североникель», 50\% - АО «Печенганикель». При этом $100 \%$ акций обоих комбинатов принадлежали частному капиталу - ОАО «РАО «Норильский никель».
}

ятий являются «стационарными», то есть тесно привязанными к конкретному пространству. И важным был вопрос о том, кто контролирует эти предприятия - «свои» бизнес-структуры, тесно сотрудничающие с региональными и городскими властями, или «чужие», воздействовать на которые сложно. Поэтому региональные власти активно вмешивались в процесс как при исходном разделении государственной собственности, так и в последующие периоды преобразований, стремясь утвердить либо свой непосредственный контроль, либо «своих» собственников над главными активами территории.

Так, в 1990-е годы от имени жителей Республики Коми группа высших управленцев региона приобрела контроль над основными крупными предприятиями и участками недр, привлекательными по запасам минерального сырья [30]. Борьба «чужого» частного капитала за региональную собственность закончилась в 2001 г. сменой региональной власти и полным переходом основных предприятий в частные руки [29].

Вместе с тем сохраняется взаимодействие региональных властей и крупных предприятий за счет «миграции» чиновников в управляющие органы предприятий и наоборот. Государство, поставив чиновников во главе советов директоров, восстановило контроль над крупными предприятиями, особенно энергетическими гигантами.

Однако есть и примеры кардинального сокращения влияния государства, когда регионы превращаются в квазикорпорации и дотируются крупными компаниями [19, 28]: например, ОАО «РАО «Норильский никель», который практически целиком формирует бюджет Таймырского автономного округа и в значительном объеме финансирует его социальную сферу. «Норильский никель» практически 
полностью осуществляет контроль над Таймырским АО. Слияние корпорации и региона достигает максимального уровня представители корпораций входят во властные структуры и даже назначаются губернаторами регионов. В результате крупные компании становятся единым целым с регионом, отвечая за экономическую и социальную политику и за функционирование систем жизнеобеспечения, региональную инфраструктуру и т.д.

Идёт перераспределение влияния не только между компаниями и государством, но и между уровнями властями. Зачастую это происходит путем установления формальных экологических и социальных ограничений для корпоративных структур. В Ханты-Мансийском АО региональные власти после ослабления своих правомочий в области недропользования (вследствие передачи основных функций контроля на федеральный уровень) в 2004 г. утвердили новые предельно допустимые нормы загрязнения водных ресурсов для нефтегазовых компаний [29].

Такое нововведение было направлено и на возврат частичного контроля над крупными внешними собственниками в округе, поскольку, несмотря на необходимость ужесточения экологических норм и ранее, регион ввел их лишь тогда, когда потерял реальные права контроля и прямого влияния на поведение компаний.

Основным инструментом проведения государственной политики в Арктике становится выделение стратегических отраслей (ТЭК, транспорт, связь) в область приоритетного государственного контроля и регулирования [33]. Это происходит путем формирования крупных бизнес-структур, которые консолидируют в своих руках права контроля над наиболее ценными активами территории: например, в Республике Саха (Якутия) такой суперорганизацией стала АК «АЛРОСА».
В середине 2000-х гг. федеральная власть взяла курс на дальнейшую приватизацию предприятий. Согласно законодательству [4], к 2009 г. органы местного самоуправления были обязаны либо приватизировать, либо передать в государственную собственность имущество, не обеспечивавшее выполнение их функций. В муниципальной собственности могли оставаться только школы, детские сады, поликлиники и больницы.

Аналогичное решение о приватизации государственного имущества было принято в отношении предприятий, не обеспечивающих выполнение государственных функций. С 2005 г. государство уменьшало количество унитарных предприятий [10]. Большинство из них проходило процедуру акционирования с сохранением 100\% акций в собственности государства. Затем они предлагались к приватизации.

Кроме того, к приватизации были предложены пакеты акций, которые принадлежали государству, размер которых не превышал 50\% уставного капитала; любые пакеты акций предприятий ТЭК, гражданской авиации и т.д., в том числе ранее входивших в список стратегических предприятий, не подлежавших приватизации.

В регионах Арктики за период 19921999 гг. приватизировано более 6000 предприятий (табл. 4).

Таблица 4. Количество приватизированных предприятий в регионах Арктики РФ

\begin{tabular}{|c|c|}
\hline Год & $\begin{array}{c}\text { Количество приватизированных } \\
\text { предприятий, нарастающим итогом }\end{array}$ \\
\hline 1993 & 3186 \\
\hline 1995 & 5268 \\
\hline 1997 & 5869 \\
\hline 1999 & 6145 \\
\hline 2001 & 6456 \\
\hline 2003 & 6619 \\
\hline 2005 & 6780 \\
\hline 2007 & 6846 \\
\hline 2009 & 6919 \\
\hline $\begin{array}{l}\text { Источник: paccчитано по данным Росстата [Эл. ресурс]. - } \\
\text { URL: http://www.gks.ru }\end{array}$ \\
\hline
\end{tabular}


За 2000-2009 гг. в рамках программы продажи непрофильного государственного и муниципального имущества было приватизировано почти 800 предприятий. Несмотря на такие значительные объемы приватизации, к настоящему времени приватизированы около 50\% предприятий от общего их числа в 1990 году ${ }^{7}$. Многие предприятия остаются государственными, хотя и сменившими организационную форму, остальные - ликвидированы либо реорганизованы в другие формы.

К 2007 г. федеральное правительство сохраняло непосредственный контроль над более чем 600 предприятиями, зарегистрированными либо работающими в арктических регионах. Из них предполагалось к дальнейшей приватизации 34 предприятия федеральной собственности со $100 \%$ пакетом акций, принадлежавших государству; 3 - с пакетом акций более 50\%; 9 - с пакетом $25-50 \%$ и $8-$ с пакетом менее $25 \% 8$. Частично это были предприятия, на которые в предыдущие периоды не нашлось покупателей ${ }^{9}$, частично - предприятия атомной промышленности и военного комплекса.

Неприватизированные предприятия зачастую остаются в государственной собственности, так как нет частных предпринимателей, готовых их приобрести. В 2007 г. к приватизации было подготовлено 80 предприятий, приватизировано - 29. В следующем году пытались приватизировать еще больше предприятий - около 120, приватизировано было только 39 [26]. Причинами этих неудач, кроме низкой

\footnotetext{
7 Рассчитано по данным Росстата [Электронный pecypc]. - URL: http://www.gks.ru

8 Рассчитано по данным Федерального агентства по управлению государственным имуществом [Электронный ресурс]. - URL: http://www.old.rosim.ru

9 Например, попытка продать акции ОАО «Морской порт «Эгвеникот», находящегося в Чукотском АО, в 2003 году провалилась [22].
}

экономической привлекательности актива этих предприятий, являются завышенная их стоимость на аукционе и продажа единым лотом.

В целом по России за последние годы увеличилась доля акционерных обществ, полностью принадлежащих государству. Можно предположить, что эта же тенденция характерна и для арктических регионов. По неполным данным, к 2010 г. федеральное правительство сохраняло контроль над предприятиями за счет участия в акционерном капитале более 200 предприятий, расположенных в арктических регионах, и являлось собственником около 400 унитарных предприятий.

Кроме того, в списке стратегических компаний РФ (т.е. не подлежащих приватизации) находилось еще 12 предприятий, которые зарегистрированы либо вели свою деятельность в Арктике.

Еще около 40 предприятий, ранее входивших в список, были исключены из него (что не означает их приватизацию; большинство преобразовано в акционерные общества со 100\%-ным госпакетом либо включено в состав госкорпораций).

В целом можно говорить об усилении государственного управления и контроля, но в основном в отношении ключевых природных ресурсов. Для России характерно почти исключительно федеральное присвоение государственной части экономической ренты от добычи нефтегазовых ресурсов, алмазов российской Арктики.

Приоритетный государственный контроль и регулирование осуществляются в отношении таких стратегических отраслей, как топливно-энергетический комплекс, транспорт и связь.

Параллельно этому есть и примеры значительного сокращения контроля государства, когда корпорации оказывают настолько заметное влияние (финансовое, 
политическое и пр.) на развитие региона, что пространство фактически приватизируется вместе с институциональной инфраструктурой и территория становится квазикорпорацией.

Усиливается переход от модели прямого, директивного вмешательства, когда государство ведет себя и как регулировщик, и как предприниматель, к принципам косвенного управления. Влияние перераспределяется как между компаниями и государством, так и между разными уровнями власти. Одним из инструментов такого опосредованного влияния является установление формальных экологических и социальных ограничений для корпораций.

Помимо того, необходимо отдельно рассмотреть процесс приватизации предприятий ЖКХ, который проводился в рамках реализации жилищной реформы, начатой в 1992 г. До того все предприятия ЖКХ арктических регионов находились либо в муниципальной, либо в ведомственной собственности.

Основной целью жилищной реформы было значительное уменьшение государственного финансирования жилищной сферы в условиях высокого бюджетного дефицита. Задачами жилищной реформы являлось также повышение качества жилья, совершенствование и повышение качества жилищных и коммунальных услуг.

Для достижения этих целей [2, 9, 14] было запланировано:

- приватизация жилых помещений (см. более подробно [18]);

- демонополизация рынка жилищнокоммунальных услуг за счет либерализации спроса и предложения на рынке ЖКХ;

- изменение политики государственного субсидирования: сокращение государственных услуг в сфере ЖКХ, переход от субсидирования коммунальных компаний к субсидированию людей с низкими доходами;
• увеличение цен на жилищно-коммунальные услуги с целью повышения привлекательности этой сферы для частного бизнеса.

Организации, управляющие домами, долгое время сохранялись в муниципальной собственности. С одной стороны, это было обусловлено желанием муниципалитетов сохранять контроль над финансовыми потоками, которые были сравнимы с объемами муниципальных бюджетов. С другой - тем, что сами жители считали муниципальную компанию более безопасной для себя, чем частные управляющие компании, которые могут значительно повысить стоимость обслуживания домов.

Создание в 2007 г. госкорпорации Фонда содействия реформированию жилищно-коммунального хозяйства (далее - Фонд) - изменило ситуацию с участием государственных и муниципальных органов власти в жилищной сфере [5]. В 2007 г. из 9 арктических регионов, по которым есть статистические данные, был готов выполнить эти условия Фонда только один - Карелия.

В целом по всем арктическим регионам только в 8 городах, расположенных в четырёх регионах, частные управляющие компании занимали около 50\% рынка жилищных услуг. В 2008 г. уже 7 из 9 регионов удовлетворяли требованиям по коммерциализации рынка управляющих услуг. В 2010 г. в пяти регионах доля частных управляющих компаний превысила 50\% жилищного фонда, в трех - составила около $40 \%$ и только в Чукотском АО - 20\% ${ }^{10}$ [27].

${ }^{10}$ Несмотря на то, что ни в одном из регионов Арктики не были выполнены требования законодательства, в том числе не достигнута $80 \%$ доля жилого фонда муниципалитета, находящегося под управлением частных компаний, все регионы получали финансовую поддержку из Фонда. Это связано в основном с тем, что такие требования должны были выполняться в конкретном муниципалитете, а не в среднем по региону. 
Многие частные управляющие компании появились путем реорганизации муниципальных управляющих компаний в частные, как правило, посредством акционирования. Городские власти старались сохранить влияние в новых компаниях через владение $25 \%$ акций и более. В г. Мурманске, например, в 2008 г. муниципальная управляющая компания была преобразована в три акционерных общества, в каждом из которых муниципалитет через другие муниципальные предприятия (что позволяло обходить требования Фонда) владел от 40 до 50\% акций. Эти три компании управляли 94\% жилищного фонда города. Однако изменения, произошедшие в органах власти (смена мэра и приход к власти новых лиц), а также борьба внутри властных структур привели к тому, что начали создаваться новые, уже полностью частные, управляющие компании, которые, используя административный ресурс, оттянули на себя большую часть жилищного фонда города. В начале 2010 г. функционировало уже около 12 управляющих компаний [24].

С помощью административного ресурса предпринимались попытки перехватывать финансовые потоки, идущие из федерального бюджета на капитальные ремонты домов. Ассоциациям собственников и «чужим» управляющим компаниям на уровне региона навязывался выбор определенных подрядчиков для проведения капитальных ремонтов, как это произошло в Мурманской области в 2010 г. [23, 32].

В начале лета 2010 г. ряду управляющих компаний были выделены средства из Фонда на проведение капитальных ремонтов. Региональные власти, являвшиеся распорядителями этих средств, основным условием их получения поставили проведение конкурса среди подрядчиков. Проведение конкурса привело к задержке получения денег на 3-4 месяца. Т.е., по сути, к работам можно было приступать только осенью или в начале зимы. Для арктических условий это является неприемлемым, поскольку в осенне-зимний период стоимость работ резко увеличивается.

Кроме того, по условиям конкурса подрядчики должны были входить в одну и ту же саморегулируемую организацию строителей, куда входили лишь крупные фирмы, для которых предлагаемые объемы работ являлись малоинтересными. В результате, даже несмотря на то, что организации, выигравшие конкурс, соответствовали предъявляемым условиям, подрядчики так и не смогли сразу приступить к работе $[16,17]$, поскольку региональные власти задержали передачу необходимых документов. Следовательно, властные структуры продолжали попытку воздействия на процессы, происходящие в жилищно-коммунальной сфере, и сохранения контроля над финансовыми потоками.

Еще одним из условий предоставления Фондом бюджетных дотаций являлось то, что жилищный фонд должен был обслуживаться частными коммунальными компаниями. К2010 г. ихдоля должна была составлять не менее 50\% жилищного фонда, к 2011 г. не менее $80 \%$. При этом общая доля самого муниципалитета и региона в этих компаниях не могла превышать 25\%.

Как правило, большинство коммунальных предприятий действовали в виде либо муниципальных, либо областных унитарных предприятий. Требование Фонда о приватизации выполнялось медленно. Так, из пяти крупных водоснабжающих предприятий Мурманской области к 2010 г. были переведены в форму акционерного общества только два, со $100 \%$ государственным и муниципальным капиталом (OAO «Апатитыводоканал» и ОАО «Мончегорскводоканал»). Три водоснабжающих предприятия, одно из которых являлось 
крупнейшим в области, остались унитарными (ГОУП «Мурманскводоканал», МУП «Североморскводоканал», ГОУП «Кандалакшаводоканал»).

Тепло- и электроснабжающие компании, как правило, являются акционерными обществами. Однако все они входят в крупные компании, включающие в себя большое количество переподчиненных акционерных обществ. В свою очередь, часть таких крупных компаний, стоящих на верхушке этой пирамиды, имеет государственное присутствие, часть - нет. Теплоснабжающие предприятия, принадлежащие региональному правительству, обычно банкротятся. Связано это в основном с накоплением у них больших долгов перед поставщиками топлива из-за неплатежей потребителей. В Мурманской области в 2005 г. были объединены в одно областное унитарное предприятие (ГОУТП «Тэкос») 5 организаций, обеспечивающих теплоснабжение для $70 \%$ населения региона. Это предприятие, работавшее с убытками в течение 2005-2009 гг., продолжает балансировать на грани банкротства до настоящего времени.

Проблема теплоснабжения остается крайне острой для арктических регионов. Все городские поселения имеют централизованную схему теплоснабжения. Изношенные сети, накопленные населением и предприятиями долги приводят к тому, что к зимнему периоду населенные пункты остаются без тепла. В отдаленных поселениях стоимость доставки топлива настолько высока, что отопление 1 м $^{2}$ обходится населению в 10-12 раз выше, чем в областном центре [20]. В связи с этим муниципалитетам предоставляются из региональных бюджетов (в особых случаях - из федерального) дополнительные дотации на закупку топлива (в рамках «северного завоза») и ремонты теплосетей.
Обеспечение теплоснабжения арктических регионов, в особенности отдаленных поселений, происходит через так называемый «северный завоз» ${ }^{11}$. В 1990-е гг. финансирование доставки топлива и продовольствия осуществлялось по следующей схеме: федеральный бюджет выделял целевой бюджетный кредит регионам в соответствии с их заявками. Затем региональные бюджеты должны были вернуть эти средства в федеральный бюджет, но из-за дефицитности большинства региональных бюджетов чаще всего средства не возвращались. В 1999 г. механизм финансовой поддержки «северного завоза» несколько изменяется. Образуется Фонд целевых субвенций, средства которого направляются регионам на оказание безвозмездной финансовой помощи при организации «северного завоза». Право выдавать из федерального бюджета беспроцентные бюджетные ссуды осталось.

В 2005 г. механизм поддержки «северного завоза» изменился: регионы сами стали отвечать за «северный завоз» на своих территориях [34]. В настоящее время его государственная поддержка состоит в предварительном выделении бюджетного кредита на закупку необходимого продовольствия и топлива и их доставку с последующим погашением кредита [36].

Тенденция сокращения федерального финансирования, государственного воздействия характерна для всех сфер жизнеобеспечения в Арктике. Приоритетный государственный контроль и регулирование осуществляются только в отношении стратегических отраслей (ТЭК, транспорт, связь). Соответственно, и основные перспективы национальной политики в отношении развития Арктики видятся в

11 Рассчитано по данным Федерального агентства по управлению государственным имушеством [Электронный ресурc]. - URL: http://www.old.rosim.ru 
освоении ресурсов шельфа арктических морей, развитии соответствующих транспортных коридоров и инфраструктуры, а также обеспечении военной безопасности российской Арктики.

\section{Заключение}

Советская модель государственной политики в Арктике характеризовалась сверхцентрализованностью, директивным управлением и максимальным участием государства во всех сферах жизни. Реформирование советской политической и экономической системы кардинально изменило отношение государства к арктическим регионам. Произошел переход от методов прямого административного управления к косвенным методам, основанным на законодательном регулировании, использовании финансовых инструментов и неформальном взаимодействии.

Государственное присутствие в экономике регионов Арктики сократилось за счет перехода прав собственности на значительную часть компаний в частный сектор. Но государство продолжает сохранять в своей собственности земли и природные ресурсы, а также предприятия, стратегически важные для страны. При этом муниципальная собственность по существу ликвидирована и у муниципалитетов крайне мало реальных инструментов воздействия на социальноэкономическую ситуацию.

В жилищной сфере государственная собственность практически полностью переведена в муниципальную и частную. Компании, предоставляющие жилищнокоммунальные услуги, в значительной степени становятся частными и эта тенденция усиливается. Сократилась государственная поддержка, в первую очередь финансовая, систем жизнеобеспечения отдаленных территорий Арктики.

Таким образом, можно говорить об усилении в последние годы государственного управления и контроля, но лишь в отношении ключевых природных ресурсов. В остальных сферах происходит переход от модели прямого, директивного вмешательства к опосредованному управлению.

\section{Литература}

1. О приватизации государственных и муниципальных предприятий в Российской Федерации: Закон РФ от 03.07.1991 №1531-1 (ред. от 17.03.1997) [Эл. ресурс] // СПС «Консультант плюс».

2. Об основах федеральной жилищной политики: Закон РФ от 24.12.1992 №4218-1 (ред. от 22.08.2004) [Эл. ресурс] // СПС «Консультант плюс».

3. О приватизации государственного и муниципального имущества: Федеральный закон от 21.12.2001 №178 [Эл. ресурс] // СПС «Консультант плюс».

4. Об общих принципах организации местного самоуправления в РФ: Федеральный закон от 06.10.2003 №131 [Эл. ресурс] // СПС «Консультант плюс».

5. О Фонде содействия реформированию жилищно-коммунального хозяйства: Федеральный закон от 21.07.2007 № 185 (ред. от 05.04.2013) [Эл. ресурс] // СПС «Консультант плюс».

6. О Государственной программе приватизации государственных и муниципальных предприятий в Российской Федерации: Указ Президента РФ от 24.12.1993 №2284 (ред. от 28.09.2011) [Эл. ресурс] // СПС «Консультант плюс».

7. О мерах по реализации промышленной политики при приватизации государственных предприятий: Указ Президента РФ от 16.11.1992 №1392 [Эл. ресурс] // СПС «Консультант плюс».

8. Основные положения Государственной программы приватизации государственных и муниципальных предприятий в Российской Федерации после 1 июля 1994 г.: Указ Президента РФ от 22.07.1994 №1535 [Эл. ресурс] // СПС «Консультант плюс». 
Государственное участие в экономическом развитии Арктики России: приватизация...

9. О реформе жилищно-коммунального хозяйства в Российской Федерации: Указ Президента РФ от 28.04.1997 №425 (ред. от 27.05.1997) [Эл. ресурс] // СПС «Консультант плюс»

10. Об утверждении Перечня стратегических предприятий и стратегических акционерных обществ: Указ Президента РФ от 04.08.2004 № 1009 (ред. от 01.10.2010) [Эл. ресурс] // СПС «Консультант плюс».

11. О разграничении государственной собственности в Российской Федерации на федеральную собственность, государственную собственность республик в составе РФ, краев, областей, автономных областей, автономных округов, городов Москвы и Санкт-Петербурга и муниципальную собственность: Постановление ВС РФ от 27.12.1991 №3020-1 (ред. от 24.12.1993) [Эл. ресурс] // СПС «Консультант плюс».

12. Об утверждении прогнозного плана (программы) приватизации федерального имущества на 2007 г. и основных направлений приватизации федерального имущества на 2007-2009 гг.: Распоряжение Правительства РФ от 25.08.2006 №1184-р [Эл. ресурс] // СПС «Консультант плюс».

13. Об утверждении Положения об определении пообъектного состава федеральной, государственной и муниципальной собственности и порядке оформления прав собственности: Распоряжение Президента РФ от 18.03.1992 №114-рп [Эл. ресурс] // СПС «Консультант плюс».

14. О Государственной целевой программе «Жилище»: Постановление Правительства РФ от 20.06.1993 №595 (ред. от 26.07.2004) [Эл. ресурс] // СПС «Консультант плюс».

15. О разграничении предметов ведения и полномочий между федеральными органами государственной власти РФ и органами власти краев, областей, городов Москвы и Санкт-Петербурга РФ: Федеративный договор от 31.03.1992 [Эл. ресурс] // СПС «Консультант плюс».

16. Герчина, О. С правительством не согласны! / О. Герчина // Дважды два. - 2010. - 30 июля.

17. Герчина, О. Ждать нет сил / О. Герчина // Дважды два. - 2010. - 24 сент.

18. Залкинд, Л.О. Жилищная политика в России: Северное измерение / Л.О. Залкинд, Е.Е. Торопушина. Апатиты: Изд-во КНЦ РАН, 2009. - 230 с.

19. Зеленко, Б.И. Финансово-промышленные группы в российском политическом процессе / Б.И. Зеленко // Социологические исследования. - 2004. - №5. - С. 108-113.

20. Золотое тепло [Эл. ресурс] // Интернет-портал Туруханского района. - URL: http://www.turuhanskregion.ru/publ/5-1-0-52

21. Зубарева, Т.А. От государственной собственности - к частной и смешанной формам собственности (на примере работы Фонда имущества Мурманской области) / Т.А. Зубарева // Север и рынок. - Апатиты: Изд-во КНЦ РАН. - 2000. - №1. - С. 152-156.

22. Квитко, Е. Очень специальный аукцион / Е. Квитко, Л. Телень // Московские новости. - 2001. - 12 июня.

23. Коммунальное рейдерство в ассортименте [Эл. ресурс] // Вестник жилищного самоуправления». 2009. - №2. - URL: http://tsg-rf.ru/book/export/html/253

24. Никитин, А. Жилищно-коммунальная хватка / А. Никитин // Новый Вест-Курьер. - 2009. - 29 апреля.

25. Отчет Федерального агентства по управлению государственным имуществом за 2003 г. [Эл. ресурс]. URL: http://www.old.rosim.ru

26. Отчет Федерального агентства по управлению государственным имуществом за 2008 г. [Эл. ресурс]. URL: http://www.old.rosim.ru

27. Отчеты Государственной корпорации - Фонда содействия реформированию жилищно-коммунального хозяйства за 2007, 2008, 2009 гг. [Эл. pecypc]. - URL: http://www.fondgkh.ru/result/index.html

28. Пачина, Т. Экстерриториальность капитала сырьевых корпораций: региональный аспект / Т. Пачина, Г. Почивалова // Проблемы прогнозирования. - 2005. - №5. - С. 85-95.

29. Пилясов, А. Региональная собственность в России: свои и чужие / А. Пилясов // Отечественные записки. - 2005. - №1. - С. 84-111.

30. Республика Коми: от Спиридонова к Торлопову и обратно // Портал «Новости Коми» 06.02.2007. URL: http://www.komi.in/archive/2007/02/06/003765.html

31. Российский Север и федерализм: поиск новой модели / под ред. А. Пилясова. - Магадан: СВКНИИ ДВО РАН, 1997. - 180 c.

32. Северный шантаж. У чиновников Мурманска есть проверенное ноу-хау [Эл. ресурс] // Вестник жилищного самоуправления». - 2009. - №2. - URL: http://tsg-rf.ru/book/export/html/253 
33. Селин, В.С. Экономический кризис и устойчивое развитие северных территорий / В.С. Селин // Север и рынок. - Апатиты: Изд-во КНЦ РАН, 2011. - № 1(27). - С. 20-25.

34. Серова, В.А. Анализ законодательного обеспечения системы «северного завоза» в районы Крайнего Севера / В.А. Серова // Север и рынок. - 2007. - №17. - С. 40-48.

35. Ход приватизационного процесса в 1995 г. // Федеральный портал protown.ru [Эл. pecypc]. - URL: http://www.protown.ru/information/hide/3068.html

36. Шпак, А.В. Проблемы и современные тенденции формирования транспортной инфраструктуры на Севере / А.В. Шпак, В.А. Серова // Север и рынок: формирование экономического порядка. - 2011. №1. - C. 165-170.

\section{References}

1. O privatizatsii gosudarstvennykh i munitsipal'nykh predpriyatiy v Rossiyskoy Federatsii: Zakon RF ot 03.07.1991 №1531-1 (red. ot 17.03.1997) [Law of the Russian Federation "On the Privatization of State and Municipal Enterprises in the Russian Federation" No.1531-1 of July 3, 1991 (Amended on March 17, 1997)]. Available at: http://www.consultant.ru/.

2. Ob osnovakh federal'noy zhilishchnoy politiki: Zakon RF ot 24.12.1992 №4218-1 (red. ot 22.08.2004) [Law of the Russian Federation "On the Fundamentals of Federal Housing Policy" No.4218-1 of December 24, 1992 (Amended on August 22, 2004)]. Available at: http://www.consultant.ru/.

3. O privatizatsii gosudarstvennogo i munitsipal'nogo imushchestva: Federal'nyy zakon ot 21.12.2001 №178 [Federal Law "On the Privatization of State and Municipal Property" No.178 of December 21, 2001]. Available at: http:// www.consultant.ru/.

4. Ob obshchikh printsipakh organizatsii mestnogo samoupravleniya v RF: Federal'nyy zakon ot 06.10.2003 №131 [Federal Law "On the General Principles of Organization of Local Self-Government in the Russian Federation" No.131 of October 6, 2003]. Available at: http://www.consultant.ru/.

5. O Fonde sodeystviya reformirovaniyu zhilishchno-kommunal'nogo khozyaystva: Federal'nyy zakon ot 21.07.2007 №185 (red. ot 05.04.2013) [Federal Law “On the Fund for Support to the Reforming of Housing and Utilities Sector" No.185 of July 21, 2007 (Amended on April 5, 2013)]. Available at: http://www.consultant.ru/.

6. O Gosudarstvennoy programme privatizatsii gosudarstvennykh i munitsipal'nykh predpriyatiy v Rossiyskoy Federatsii: Ukaz Prezidenta RF ot 24.12.1993 №2284 (red. ot 28.09.2011) [Decree of the President of the Russian Federation "On the State Program for Privatization of State and Municipal Enterprises in the Russian Federation" No.2284 of December 24, 1993 (Amended on September 28, 2011)]. Available at: http://www.consultant.ru/.

7. O merakh po realizatsii promyshlennoy politiki pri privatizatsii gosudarstvennykh predpriyatiy: Ukaz Prezidenta RF ot 16.11.1992 № 1392 [Decree of the President of the Russian Federation "On the Measures for the Implementation of Industrial Policy under the Privatization of State Enterprises" No.1392 of November 16, 1992]. Available at: http://www.consultant.ru/.

8. Osnovnye polozheniya Gosudarstvennoy programmy privatizatsii gosudarstvennykh i munitsipal'nykh predpriyatiy $v$ Rossiyskoy Federatsii posle 1 iyulya 1994 g.: Ukaz Prezidenta RF ot 22.07.1994 №1535 [Decree of the President of the Russian Federation "Main Provisions of the State Program for Privatization of State and Municipal Enterprises in the Russian Federation after July 1, 1994” of July 22, 1994 No.1535]. Available at: http://www. consultant.ru/.

9. O reforme zhilishchno-kommunal'nogo khozyaystva v Rossiyskoy Federatsii: Ukaz Prezidenta RF ot 28.04.1997 №425 (red. ot 27.05.1997) [Decree of the President of the Russian Federation "On the Reform of the Housing and Utilities Sector in the Russian Federation” No.425 of April 28, 1997 (Amended on May 27, 1997)]. Available at: http://www.consultant.ru/.

10. Ob utverzhdenii Perechnya strategicheskikh predpriyatiy i strategicheskikh aktsionernykh obshchestv: Ukaz Prezidenta RF ot 04.08.2004 №1009 (red. ot 01.10.2010) [Decree of the President of the Russian Federation "On the Approval of the List of Strategic Enterprises and Strategic Joint Stock Companies” No.1009 of August 4, 2004 (Amended on October 1, 2010)]. Available at: http://www.consultant.ru/.

11. O razgranichenii gosudarstvennoy sobstvennosti v Rossiyskoy Federatsii na federal'nuyu sobstvennost', gosudarstvennuy u sobstvennost' respublik v sostave RF, kraev, oblastey, avtonomnykh oblastey, avtonomnykh okrugov, gorodov Moskvy i Sankt-Peterburga i munitsipal'nuyu sobstvennost': Postanovlenie VS RF ot 27.12.1991 №3020-1 (red. ot 24.12.1993) [Resolution of the Supreme Soviet of the Russian Federation "On the Differentiation of the State Property of the Russian Federation into the Federal Property, the State Property of the Russian Federation 
Государственное участие в экономическом развитии Арктики России: приватизация...

Republics, Krais, Oblasts, Autonomous Oblasts, Autonomous Okrugs, Cities of Moscow and Saint Petersburg, and Municipal Property" No.3020-1 of December 27, 1991 (Amended on December 24, 1993)]. Available at: http://www.consultant.ru/.

12. Ob utverzhdenii prognoznogo plana (programmy) privatizatsii federal'nogo imushchestva na $2007 \mathrm{~g}$. i osnovnykh napravleniy privatizatsiifederal'nogo imushchestva na 2007-2009gg.: Rasporyazhenie Pravitel'stva RF ot 25.08.2006 №1184- $r$ [Resolution of the Government of the Russian Federation "On the Approval of the Forecast Plan (Program) for the Privatization of Federal Property for 2007 and the Main Directions of Federal Property Privatization for 2007-2009” No.1184-r of August 25, 2006]. Available at: http://www.consultant.ru/.

13. Ob utverzhdenii Polozheniya ob opredelenii poob"ektnogo sostava federal'noy, gosudarstvennoy $i$ munitsipal'noy sobstvennosti i poryadke oformleniya prav sobstvennosti: Rasporyazhenie Prezidenta RF ot 18.03.1992 №114-rp [Resolution of the President of the Russian Federation "On the Approval of the Provisions on the Definition of Object-by-Object Composition of the Federal, State and Municipal Property and the Order of Registration of Property Rights" No.114-rp of March 18, 1992]. Available at: http://www.consultant.ru/.

14. O Gosudarstvennoy tselevoy programme "Zhilishche": Postanovlenie Pravitel'stva RF ot 20.06.1993 №595 (red. ot 26.07.2004) [Resolution of the Government of the Russian Federation "On State Target Program "Housing" No.595 of June 20, 1993 (Amended on July 26, 2004)]. Available at: http://www.consultant.ru/.

15. O razgranichenii predmetov vedeniya i polnomochiy mezhdu federal'nymi organami gosudarstvennoy vlasti $R F i$ organami vlasti kraev, oblastey, gorodov Moskvy i Sankt-Peterburga RF: Federativnyy dogovor ot 31.03.1992 [Federal Agreement "On Delimitation of Matters of Authority and Powers between Federal Government Bodies of the Russian Federation and Government Bodies of Krais, Oblasts, Cities of Moscow and Saint Petersburg of the Russian Federation" of March 31, 1992]. Available at: http://www.consultant.ru/.

16. Gerchina O. S pravitel'stvom ne soglasny! [We Do not Agree with the Government!]. Dvazhdy Dva Newspaper, 2010, issue of July 30 .

17. Gerchina O. Zhdat' net sil [Sick and Tired of Waiting], Dvazhdy Dva Newspaper, 2010, issue of September 24.

18. Zalkind L.O., Toropushina E.E. Zhilishchnaya politika v Rossii: Severnoe izmerenie [Housing Policy in Russia: the Northern Dimension]. Apatity: KNTs RAN Publ., 2009. 230 p.

19. Zelenko B.I. Finansovo-promyshlennye gruppy v rossiyskom politicheskom protsesse [Financial and Industrial Groups in the Russian Political Process]. Sotsiologicheskie issledovaniya [Sociological Studies], 2004, no.5, pp. 108-113.

20. Zolotoe teplo [Golden Heat]. Available at: http://www.turuhansk-region.ru/publ/5-1-0-52

21. Zubareva T.A. Ot gosudarstvennoy sobstvennosti $-\mathrm{k}$ chastnoy i smeshannoy formam sobstvennosti (na primere raboty Fonda imushchestva Murmanskoy oblasti) [From State Ownership to Private and Mixed Forms of Ownership (Case Study of the Murmansk Oblast Property Fund)]. Sever i rynok [The North and the Market]. Apatity: KNTs RAN Publ., 2000, No.1, pp. 152-156.

22. Kvitko E., Telen' L. Ochen' spetsial'nyy auktsion. Moskovskie novosti [Moscow News], 2001, issue of June 12.

23. Kommunal'noe reyderstvo $\mathrm{v}$ assortimente [Municipal Raiding in Assortment]. Vestnik zhilishchnogo samoupravleniya [Bulletin of Housing Self-Governance], 2009, no.2. Available at: http://tsg-rf.ru/book/export/ $\mathrm{html} / 253$

24. Nikitin A. Zhilishchno-kommunal'naya khvatka [Housing and Communal Grip]. Novyy Vest-Kur'er [New West Courier], 2009, issue of April 29.

25. Otchet Federal'nogo agentstva po upravleniyu gosudarstvennym imushchestvom za $2003 \mathrm{~g}$. [Report of the Federal Agency for State Property Management for 2003]. Available at: http://www.old.rosim.ru

26. Otchet Federal'nogo agentstva po upravleniyu gosudarstvennym imushchestvom za $2008 \mathrm{~g}$. [Report of the Federal Agency for State Property Management for 2008]. Available at: http://www.old.rosim.ru

27. Otchety Gosudarstvennoy korporatsii - Fonda sodeystviya reformirovaniyu zhilishchno-kommunal'nogo khozyaystva za 2007, 2008, $2009 \mathrm{gg}$. [Reports of the State Corporation - the Fund for Support to the Reforming of Housing and Utilities Sector for 2007, 2008, 2009]. Available at: http://www.fondgkh.ru/result/index.html

28. Pachina T. Pochivalova G. Eksterritorial'nost' kapitala syr'evykh korporatsiy: regional'nyy aspekt [Extraterritoriality of the Capital of the Raw Materials Corporations: Regional Aspect]. Problemy prognozirovaniya [Issues of Forecasting], 2005, no.5, pp. 85-95.

29. Pilyasov, A. Regional'naya sobstvennost' v Rossii: svoi i chuzhie [Regional ownership in Russia: insiders and outsiders]. Otechestvennye zapiski [Domestic Notes], 2005, no.1, pp. 84-111. 
30. Respublika Komi: ot Spiridonova k Torlopovu i obratno [Komi Republic: from Spiridonov to Torlopov and Back]. Komi News Portal. February 06, 2007. Available at: http://www.komi.in/archive/2007/02/06/003765.html

31. Rossiyskiy Sever i federalizm: poisk novoy modeli [Russian North and Federalism: Search for a New Mode]. Ed. by A. Pilyasov. Magadan: SVKNII DVO RAN, 1997. 180 p.

32. Severnyy shantazh. U chinovnikov Murmanska est' proverennoe nou-khau [Northern Blackmail. Murmansk Officials Have a Reliable Know-How]. Vestnik zhilishchnogo samoupravleniya [Bulletin of Housing SelfGovernance], 2009, no.2. Available at: http://tsg-rf.ru/book/export/html/253

33. Selin V.S. Ekonomicheskiy krizis i ustoychivoe razvitie severnykh territoriy [Economic Crisis and Sustainable Development of Northern Territories] Sever i rynok. Apatity: Izd-vo KNTs RAN, 2011, no.1(27), pp. 20-25.

34. Serova V.A. Analiz zakonodatel'nogo obespecheniya sistemy "severnogo zavoza” v rayony Kraynego Severa [Analysis of the Legal Framework of the System of "Northern Delivery" to the Far North Regions]. Sever i rynok, 2007, no.17, pp. 40-48.

35. Khod privatizatsionnogo protsessa v 1995 g. [The Progress of Privatization in 1995]. Federal Portal protown.ru. Available at: http://www.protown.ru/information/hide/3068.html

36. Shpak A.V., Serova V. A. Problemy i sovremennye tendentsii formirovaniya transportnoy infrastruktury na Severe [Problems and Modern Trends in the Development of Transport Infrastructure in the North]. Sever i rynok: formirovanie ekonomicheskogo poryadka [The North and the Market: formation of economic order], 2011, no.1, pp. 165-170. 


\section{ВОПРОСЫ ТЕОРИИ}

УДК 331, ББК 65.24

(с) Леонидова Г.В.

\section{Интеллектуальный потенциал населения: теоретико-методологические основы исследования}

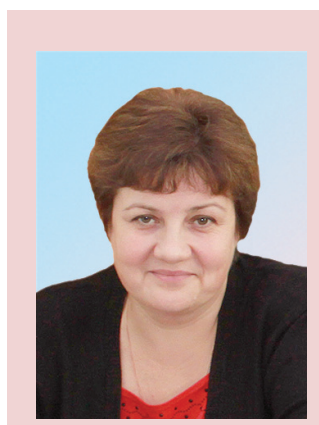

\section{Галина Валентиновна ЛЕОНИДОВА}

кандидат экономических наук, доцент, заведующий лабораторией исследования проблем трудового потенциала, Федеральное государственное бюджетное учреждение науки Институт социально-экономического развития территорий РАН (160014, г. Вологда, ул. Горького, 56a, galinaleonidova@mail.ru)

Аннотация. В статье рассмотрены теоретико-методологические основы исследования интеллектуального потенциала населения. В представленных материалах показано, что данная категория является предметом междисциплинарных исследований, в частности философии, психологии, социологии, педагогики, экономики. Из анализа сущности интеллектуального потенциала следует важный вывод о том, что наличный уровень интеллекта - результат его развития. А значит, определенные усилия со стороны таких социальных институтов, как семья, образование, государство, способствуют не только формированию умных людей, но и реализации их потенциальных интеллектуальных возможностей в производстве, создании культурных ценностей, управлении обществом, воспитании и т.д. При таком подходе интеллект перестает быть объектом исследования смежных дисциплин, приобретает социальную окраску и становится социально-экономической категорией.

Проанализированы основные теории, концепции и подходы, используемые при исследовании интеллектуального потенциала. Наиболее подробно освещена теория человеческого капитала, поскольку согласно данной теории доход человеку приносят знания, умения и навыки - именно то, что непосредственным образом составляет суть интеллектуальных свойств личности.

Дано авторское определение интеллектуального потенциала населения, актуализирующее такие обязательные для понимания сущности категории элементы, как взаимосвязь с социально-экономическим развитием общества, факторы формирования свойства, в том числе необходимость подготовки (воспроизводства) интеллектуальных людей, психологический аспект (способности); не игнорируются носители интеллектуального потенциала, ибо это свойство населения. 
Определены методологические подходы к оценке интеллектуального потенциала населения, раскрыты используемые процедуры и методы исследования.

Предложены методологические подходы к организации мониторинга интеллектуального потенциала населения как индикатора инновационного развития общества и эффективности государственного управления.

Ключевые слова: население, интеллект, интеллектуальный потенциал населения, трудовой потенциал, человеческий капитал, наука, образование, культура.

Leonidova G.V.

\section{Intellectual potential of population: theoretical and methodological framework for research}

Leonidova Galina Valentinovna - Ph.D. in Economics, Associate Professor, Head of the Laboratory for the Studies of Labor Potential Development Issues, Federal State-Financed Scientific Institution the Institute of Socio-Economic Development of Territories of the Russian Academy of Sciences (56A, Gorky Street, Vologda, 160014, Russia, galinaleonidova@mail.ru).

Abstract. The article considers the theoretical and methodological framework for the research into the population's intellectual potential. The presented materials show that this category is the subject of interdisciplinary studies, including philosophy, psychology, sociology, pedagogics, economics. One of the important conclusions drawn from the analysis of the essence of intellectual potential is the conclusion that the actual level of intelligence is the result of its development. It means that certain efforts on the part of such social institutions like family, education, government, promote not only the formation of smart people, but also the implementation of their potential intellectual capabilities in the production, creation of cultural values, society management, education, etc. when using this approach, the intellect ceases to be just a research object of related disciplines, but it acquires social dimension and becomes a socio-economic category.

The basic theories, concepts and approaches, used in its study, were analyzed. The theory of human capital was given a most thorough consideration, because, according to this theory, the income of a person is earned by knowledge, abilities and skills, i.e. the essence of intellectual properties of an individual.

The article provides the author's definition of the intellectual potential of the population, which brings to the fore the following elements necessary for the understanding of this category: relation to socioeconomic development, factors in the formation of the characteristic, including the need for training (reproduction) of intelligent people, the psychological aspect (abilities), the carriers of intellectual potential are not ignored, because it is an attribute of the population.

The article identifies methodological approaches to the estimation of the population's intellectual potential, describes the applied procedures and research methods.

The authors propose methodological approaches to the monitoring of the population's intellectual potential as an indicator of innovation development of the society and the efficiency of public administration.

Key words: population, intellect, intellectual potential of population, labour potential, human capital, science, education, culture. 
Стратегическая цель Российской Федерации - выход к 2020 г. на мировой уровень приоритетных исследований и разработок и освоение шестого технологического уклада $[8,16]$. Достижение цели сопряжено с наличием качественного человеческого потенциала страны. Однако для современной России (конца XX - начала XXI в.) характерно ухудшение качества населения, связанное в первую очередь со снижением его интеллектуального компонента [21]. Об этом свидетельствует серьезное научнотехнологическое отставание российской экономики: на мировых рынках высоких технологий РФ занимает $0,3 \%$, чему прежде всего способствовало существенное снижение в 90-е годы XX в. ресурсной базы научных исследований. Последовавшие за этим сокращение исследовательского корпуса (в 2 раза с 1992 по 2012 г.) и интеллектуальная миграция (масштабы утечки «мозгов» составили по оценкам исследователей около миллиона человек) значительно ослабили научно-техническое развитие страны [21].

Важным индикатором, характеризующим степень развитости интеллекта населения, служит индекс развития человеческого потенциала' ${ }^{1}$ (ИРЧП), рассчитываемый под эгидой ООН. По последнему рейтингу стран по ИРЧП (2010 г.) Россия занимает 55 место (в 1990 г. ее позиция была 33-й; табл. 1).

Хотя после существенного «провала» в конце 1990-х - начале 2000-х гг. показатель российского ИРЧП имеет положительную динамику, его значение не достигло базового уровня. Кроме того, разрыв между мировым лидером (в 1992 г. - Канада 0,982, в 2010 г. - Норвегия - 0,955) и РФ увеличивается (с 0,108 в 1990 г. до 0,112 в 2010 г.). Приходится констатировать, что за прошедшие годы среди стран, имеющих высокий ИРЧП 2 , он снизился только в России [5]. При этом ни один из субъектов РФ не достиг по ИРЧП уровня развитых стран. Данное обстоятельство красноречиво свидетельствует, что в России за годы становления рыночной экономики и на современном этапе не создано действенных организационно-экономических механизмов, способствующих эффективному воспроизводству интеллектуального потенциала населения. Сегодня эта проблема выдвигается в государственном управлении на первый план.

Продолжающаяся деинтеллектуализация российской экономики требует не только повышенного внимания органов власти к этой проблеме, но и идентификации понятия «интеллектуальный потенциал населения».

Таблица 1. Динамика индекса развития человеческого потенциала России

\begin{tabular}{|c|c|c|c|c|c|c|c|}
\hline Показатель & 1990 г. & 1992 г. & 2000 г. & 2005 г. & 2007 г. & 2009 г. & 2010 г. \\
\hline Индекс ИРЧП & 0,873 & 0,862 & 0,781 & 0,792 & 0,817 & 0,840 & 0,843 \\
\hline Место в рейтинге ООН & 33 & 37 & 60 & 67 & 71 & 66 & 55 \\
\hline \multicolumn{8}{|c|}{$\begin{array}{l}\text { Источники: Национальные доклады о человеческом развитии Российской Федерации (год публикации индекса означает, что он } \\
\text { рассчитан по показателям двухлетней давности): Россия перед лицом демографрических вызовов. - 2008. - С. 178-180; Регионы } \\
\text { России: проблемы, цели, достижения, 2006-2007. - С. 132-133; Модернизация и человеческое развитие, 2011. - С. 137; Устойчи- } \\
\text { вое развитие: вызовы РИО, 2013. - С. 149. }\end{array}$} \\
\hline
\end{tabular}

В 2010 году семейство индикаторов, которые измеряют ИРЧП, было расширено, а сам индекс подвергся существенной корректировке. В дополнение к используемому ИРЧП, который является сводным показателем, опирающимся на среднестрановые статистические данные и не учитывающим внутреннего неравенства, были введены три новых индикатора: индекс человеческого развития, скорректированный с учетом социально-экономического неравенства (ИЧРН), индекс гендерного неравенства (ИГН) и индекс многомерной бедности (ИМБ). На основании этих изменений был осушествлён перерасчёт всех имевшихся ранее данных.

2 Высоким считается индекс от 0,800 ед. 
Современное его содержание - это итог научного осмысления социально-экономической практики ведущих стран мира. В нем аккумулированы важнейшие положения многих теорий, получивших развитие в середине XX века: человеческого капитала, трудового потенциала, экономики знаний и других концепций становления постиндустриального общества, поскольку структура экономики претерпевает кардинальные изменения. Для формирования теории человеческого капитала ко II половине XX века были созданы все необходимые субъективные и объективные предпосылки (рис. 1).

Важнейшая предпосылка возникновения теории человеческого капитала научно-техническая революция конца 50-хначала 60-х годов XX века. Она вызвала глубокие преобразования в производительных силах общества, существенно усилила роль и значение личности человека в экономике, уровня его образования, научных знаний, опыта и квалификации. Другая предпосылка - превращение науки в непосредственную производительную силу. Степень наукоёмкости производства стала напрямую влиять на интенсивность производственного оборота. В странахлидерах НТП наблюдается нарастающий прогресс в развитии интеллектуальных производительных сил и формировании внушительного по абсолютным и относительным размерам невещного богатства. Наиболее значимым фактором экономического прорыва стала способность общества к созданию и внедрению инноваций.

Развитие экономической мысли постепенно способствовало смещению акцентов с материалистической трактовки источников развития к осознанию исходной роли знаний, интеллекта, созидательных способностей человека.

Для понимания экономической сущности интеллектуального потенциала населения наиболее значима теория человеческого капитала [3] (Т. Шульц, Г. Беккер). Согласно данной теории доход человеку приносят знания, умения и навыки - именно то, что непосредственным образом составляет суть интеллектуальных свойств личности. Человеческий капитал, по мнению исследователей, - это функциональная составляющая инновационного производства («знания, навыки, практический опыт, одухотворенные интеллектуальной активностью, выступающей формой реализации интеллектуальных, нравственно и культурно-ориентированных способностей человека к созданию нового, ранее неизвестного знания, обеспечивающего получение интеллектуальной ренты и различного рода преимуществ перед конкурентами») [26, с. 332]. Из этого следует, что интеллектуальная активность является тем компонентом, который отличает способности к творческому труду от способностей к исполнительскому труду, человеческий капитал от простой рабочей силы, определяет условия и природу процесса «капитализации» интеллектуальных способностей к труду.

Анализ имеющихся определений «интеллектуального потенциала населения» показал, что общепринятого понимания этой категории современной наукой не выработано. Мы выделили три методологических подхода:

- философский [1, с. 1472], трактующий интеллектуальный потенциал как «некую абстрактную категорию, лишенную способности изменяться во времени, но имеющую изначальную созидательную силу» (Ф. Аквинский, А.А. Ухтомский, П.А. Флоренский и др.);

- психолого-педагогический [25, с. 25], определяющий интеллектуальный потенциал как «способность к обучению, обучаемость» и относящий к интеллектуальным качествам личности компетентность, 


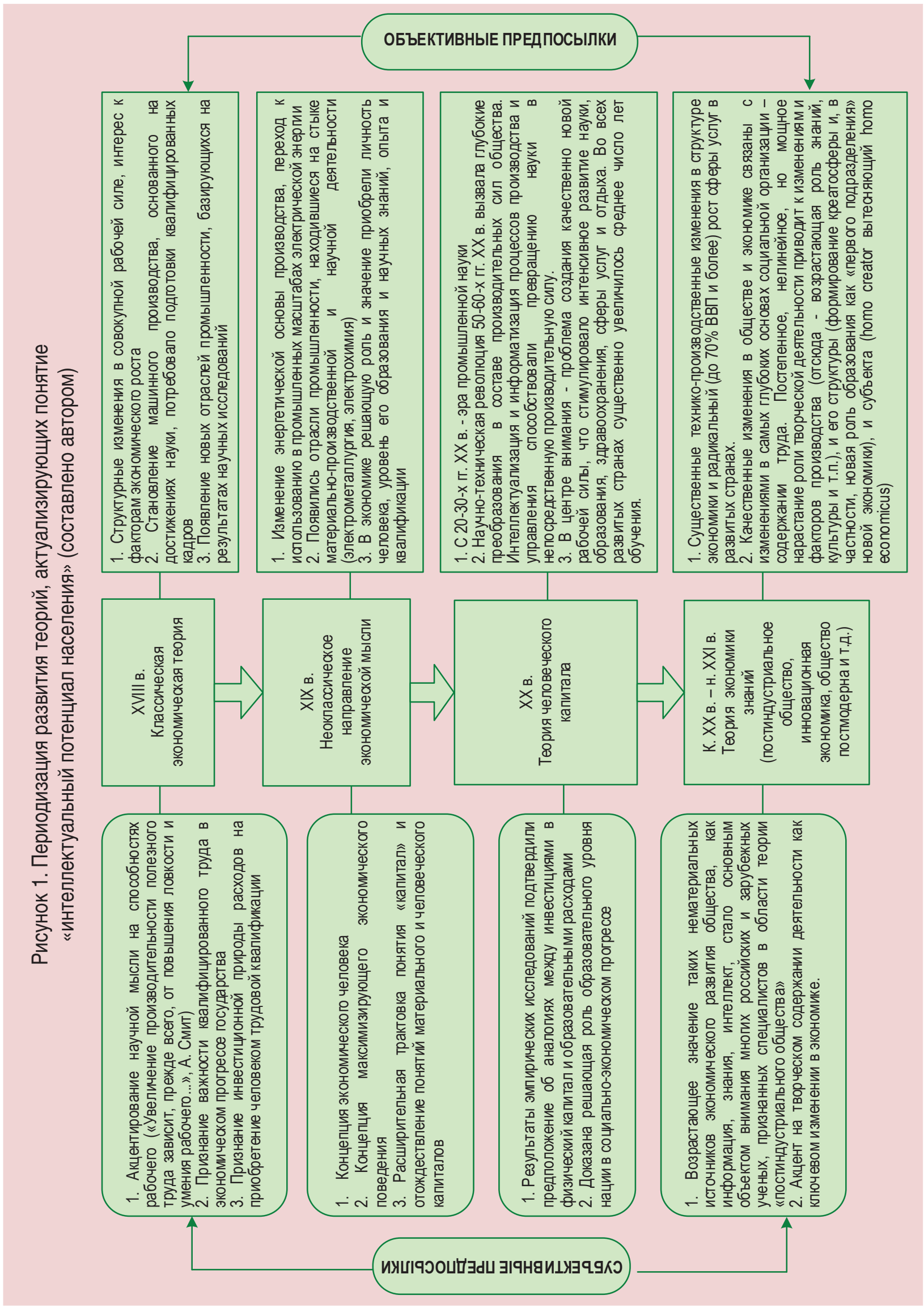


инициативу, творчество, саморегуляцию, уникальность склада ума (Д.Б. Богоявленская, Л.С. Выготский, А.И. Кочетов, А.И. Субетто и др.);

- социально-экономический [7, с. 228; $12,16,26]$, соотносящий комплексную характеристику уровня развития интеллектуальных, творческих возможностей ресурсов страны, отрасли, личности с функционированием сфер образования и науки и ускорением научно-технического прогресса (В.К. Левашов, Б.Г. Клейнер, Ю.П. Лежнина, Р.Е. Лещинер, А.И. Татаркин, А.Ф. Мартынов и др.; табл. 2).

Сущность интеллектуального потенциала населения необходимо рассматривать через два ключевых понятия - «интеллект» и «Потенциал».

Категория «потенциал» носит общенаучный характер: она используется в математике, физике, технике, биологии, химии, экономике, социологии и других отраслях знаний. В экономической литературе ею оперировали еще в 20 -е гг. XX в. при разработке комплексной оценки уровня развития производительных сил. «Потенциал» (от лат. potentia - сила) трактуется как «средства, запасы, источники, имеющиеся в наличии и могущие быть мобилизованы, приведены в действие, использованы для достижения определенной цели, осуществления плана, решения какой-либо задачи; возможности отдельного лица, общества, государства в определенной области» [4, с. 428].

Интеллект является свойством индивида. При этом интеллект нельзя отождествлять с мышлением. Одно из различий состоит в том, что мышление является процессом осмысливания и решения некоторой мыслительной задачи. Второе связано с тем, что мышление возникает тогда, когда появляется практическая задача, а способность к мышлению (интеллект) это устойчивое, постоянное свойство индивида, присушее ему на протяжении всей жизни. Отсюда следует, что интеллект является свойством индивида, определяющим возможность протекания мыслительной деятельности [24, с. 71].

Таблица 2. Основные подходы к определению интеллектуального потенциала

\begin{tabular}{|c|c|c|}
\hline $\begin{array}{l}\text { Основные } \\
\text { подходы }\end{array}$ & Содержание & Авторы \\
\hline Философский & $\begin{array}{l}\text { Открытая динамичная система взаимодействующих когнитивно-креативной и } \\
\text { ценностно-праксеологической составляющих } \\
\text { Некая абстрактная категория, лишенная способности изменяться во времени, но } \\
\text { имеющая изначальную созидательную силу } \\
\text { Познание недоступных опыту объектов путем оперирования знаками, Символами, } \\
\text { моделями и иными репрезентантами сверхчувственного бытия } \\
\text { Способность человека, связанная с духовностью, культурным фоном личности, } \\
\text { сознанием, мышлением, направленная на рациональное познание действительности, } \\
\text { универсальной связи всех вещей, всех явлений } \\
\text { Индивидуальная ступень мышления (интеллект) возникает и формируется в начале } \\
\text { ноогенеза как чистая способность постижения смысла действия и выражения его в } \\
\text { общезначимых формах (словах, символах, знаках) }\end{array}$ & $\begin{array}{l}\text { Ф. Аквинский } \\
\text { П.А. Флоренский } \\
\text { В.С. Соловьев } \\
\text { И. Кант } \\
\text { Г. Гегель } \\
\text { А.И. Герцен } \\
\text { А.А. Ухтомский } \\
\text { В.В. Орлова } \\
\text { И.Т. Фролов } \\
\text { П. де. Шарден }\end{array}$ \\
\hline $\begin{array}{l}\text { Психолого- } \\
\text { педагогический }\end{array}$ & $\begin{array}{l}\text { «Способность к обучению, обучаемость» } \\
\text { Компетентность, инициатива, творчество, саморегуляция и уникальность склада ума } \\
\text { Богатство, которое определяет настоящее и будущее каждой страны и народа, } \\
\text { «инструмент» прогресса, показатель уровня развития общества. Это не только } \\
\text { количество образованных людей, но и уровень познавательной самостоятельности, } \\
\text { качество умственной деятельности как отдельных индивидов, так и всего народа, } \\
\text { степень умственной активности различных слоёв населения }\end{array}$ & $\begin{array}{l}\text { А.И. Субетто } \\
\text { А.А. Деркач } \\
\text { Д.Б. Богоявлен- } \\
\text { ская } \\
\text { А.И. Кочетов } \\
\text { Л.С. Выготский }\end{array}$ \\
\hline
\end{tabular}


Окончание таблицы 2

\begin{tabular}{|c|c|c|}
\hline $\begin{array}{c}\text { Основные } \\
\text { подходы }\end{array}$ & Содержание & Авторы \\
\hline $\begin{array}{l}\text { Социально- } \\
\text { экономический }\end{array}$ & 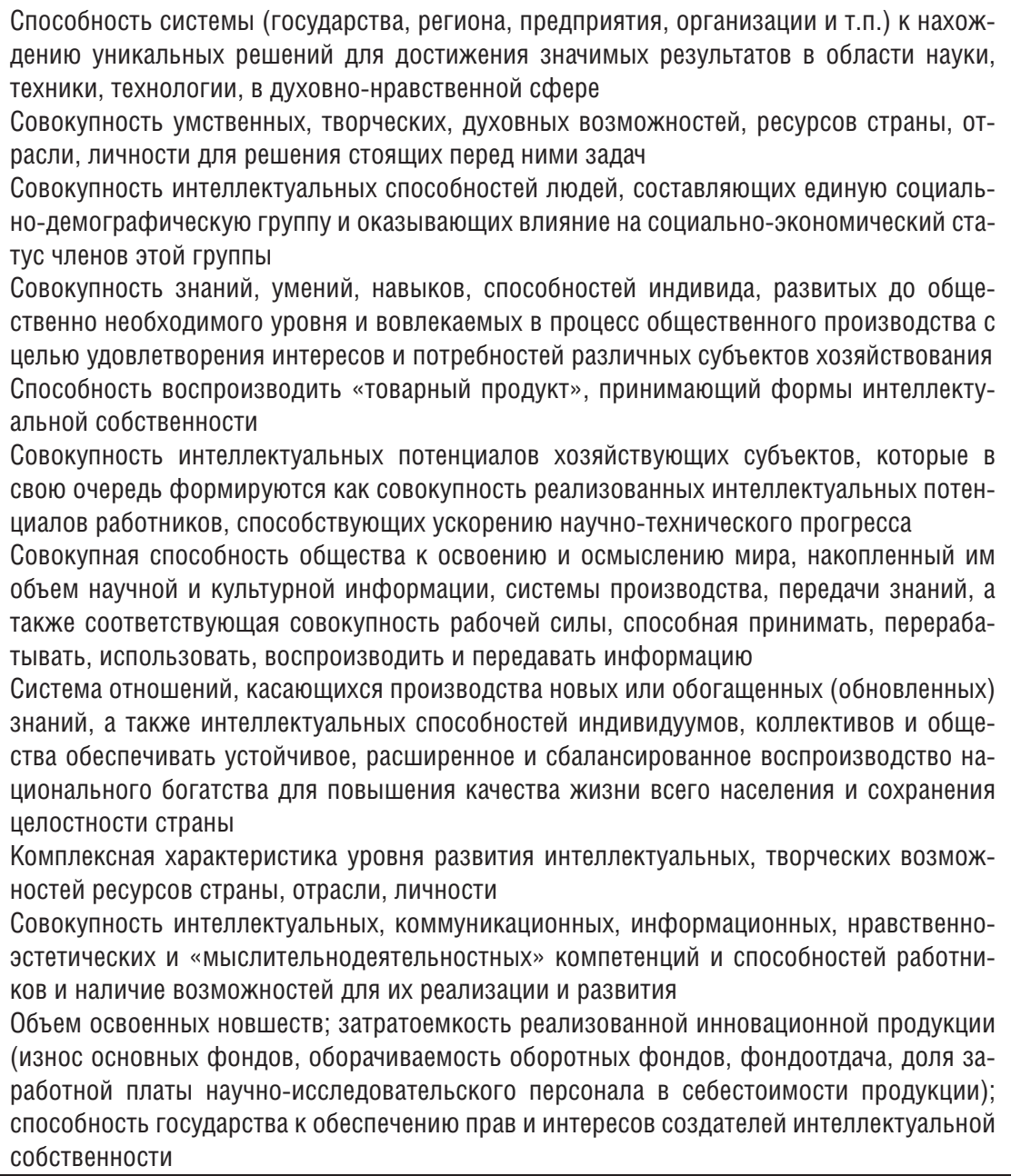 & $\begin{array}{l}\text { Е.В. Бобкова } \\
\text { М.И. Багдасаров } \\
\text { В.К. Левашов } \\
\text { Ю.П. Лежнина } \\
\text { М.Н. Руткевич } \\
\text { Ю.М. Воронин } \\
\text { Л. Я. Баранова } \\
\text { О.В. Беляева } \\
\text { А.А. Иванов } \\
\text { И.В. Усольцева } \\
\text { Е.В. Чмыхова } \\
\text { Е.Ю. Марусинина } \\
\text { Б.М. Рудицкий } \\
\text { В.А. Кадомцева } \\
\text { В.А. Иванцов } \\
\text { А.Ф. Мартынов } \\
\text { Л.А. Лемдяева } \\
\text { А.И. Татаркин } \\
\text { Р.Г. Аглямов } \\
\text { М.А. Нугаев } \\
\text { Б.Г. Клейнер } \\
\text { Д.М. Шакирова } \\
\text { Г.В. Краюхин } \\
\text { Р.Е. Лещинер }\end{array}$ \\
\hline \multicolumn{3}{|c|}{ 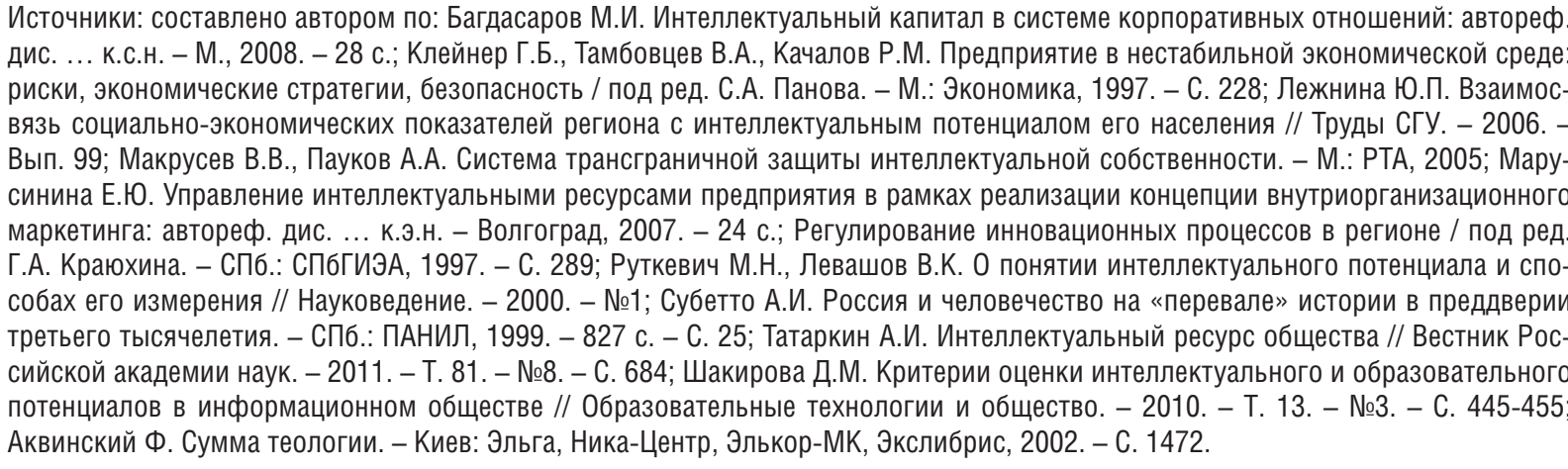 } \\
\hline
\end{tabular}

\section{Философское содержание интеллекта} современные авторы связывают с таким понятием, как ноосфера [30, с. 25]. Согласно П.Т. де Шардену, интеллект (индивидуальная ступень мышления) возникает и формируется в начале ноогенеза как чистая способность постижения смысла действия и выражения его в общезначимых формах (словах, символах, знаках). Оперирование этими формами и позволяет человеку ориентироваться в сообществе, которое и образует почву тонкой оболочки, земного универсума, названную ноосферой [30, с. 178]. 
Можно выделить основные элементы интеллекта: знания и умственные способности, достаточные условия выполнения интеллектуальным потенциалом функции - быть основой мыслительной деятельности, т.е. решения практических или теоретических задач с требуемой эффективностью. Применительно к современному миру в качестве составляющей интеллектуального потенциала человека можно выделить профессиональные компетенции (компетентности) как «синтез интеллекта, определенных типов мышления, нравственно-этических качеств и направленности деятельности». Причем компетентность, по мнению А.А. Овсянникова [18, с. 76-96], является «стратегическим ресурсом, на десятки лет предопределяющим социальную и экономическую жизнь страны».

Из определения сущности интеллекта следует важное заключение о том, что имеющийся его уровень является результатом его развития. А значит, определенные усилия со стороны таких социальных институтов, как семья, образование, государство, способствуют не только формированию умных людей, но и реализации их потенциальных интеллектуальных возможностей в производстве, создании культурных ценностей, управлении обществом, воспитании и т.д. При таком подходе интеллект перестает быть объектом исследования психологии, приобретая социальную окраску и становясь социально-экономической категорией.

Исследование не дает однозначного ответа о составляющих интеллектуального потенциала, его структуре, поскольку всё зависит от того, кому принадлежит этот потенциал - индивиду, компании (организации) или обществу в целом (страны, региона и т.д.).
В составе индивидуального интеллектуального потенциала исследователи (А.В. Сохань) выделяют такие элементы, как [24, с. 71]:

- развитые способности;

- знания, умения, навыки, то есть система духовных образований, в которой на личностном уровне отражены результаты познавательной и активно-преобразующей деятельности человека;

- идеалы, убеждения, ценностные ориентации, интересы, которые являются результатом интеллектуального осмысления человеком окружающего мира, своего места в нем [29, с. 448].

Трудности изучения интеллектуального потенциала человека (индивида) кроются в том, что знания, как правило, исследуются педагогическими науками, а способности - психологическими.

В структуре интеллектуального потенциала личности авторы выделяют, кроме знаний, образовательные и социокультурные ценности (стремление к творчеству, познанию окружающего мира, общий уровень культуры и т.д.), базовый уровень образования, профессионально-квалификационный уровень, степень таланта, способность к восприятию новшеств, которая позволяет быстрее осваивать новые технологии в производстве и управлении.

Анализируя социально-экономическую сущность понятия «интеллектуальный потенциал населения», приходим к выводу, что в работах отечественных экономистов существуют несколько разных подходов к его оценке. Их систематизация показывает, что наибольшей эвристической ценностью обладают формулировки, в которых выделяется когнитивно-креативная составляющая, ориентирующая человека на практическое применение знаний и умственных способностей. Интеллектуальный потенциал оказывается заложенным в человеке как скрытая возможность, 


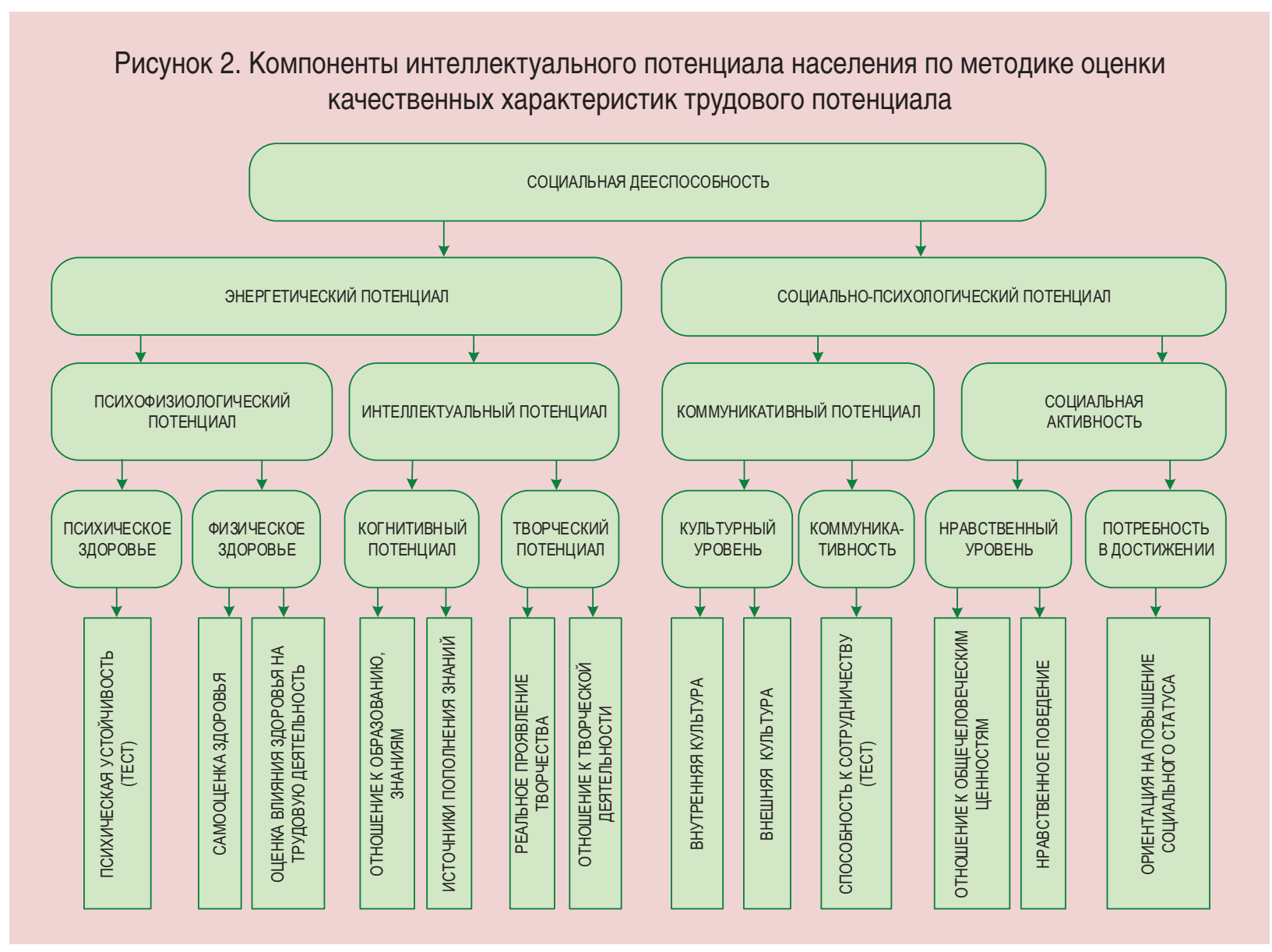

которую необходимо формировать в направлении, необходимом обществу, для дальнейшего его совершенствования. Из вышесказанного следует, что основными составными частями интеллектуального потенциала личности являются когнитивные (знаниевые) и творческие характеристики [22, с. 9; 14, с. 70].

В логику данного подхода удачно вписывается концепция качественных характеристик населения (Н.М. Римашевская), на основе которой Институтом социально-экономического развития территорий РАН проводится многолетнее исследование качества трудового потенциала населения ${ }^{3}$. В описываемом исследовании интеллектуальный потенциал рассматривается, с одной стороны, как компонент трудового потенциала, с другой стороны, как интегральная характеристика когнитивных и креативных способностей людей (рuc. 2).

\footnotetext{
3 Мониторинг качества трудового потенциала населения Вологодской области проводится ИСЭРТ РАН с 1997 года. Объектом исследования является трудоспособное население Вологодской области. Опросы проходят ежегодно в августе - сентябре в городах Вологде и Череповце и в восьми районах области (Бабаевском, Великоустюгском, Вожегодском, Грязовецком, Кирилловском, Никольском, Тарногском и Шекснинском). Метод опроса - анкетирование по месту жительства респондентов. Объём выборки составляет 1500 человек, ошибка выборки не превышает $3 \%$. Объектом исследования является трудоспособное население Вологодской области в возрасте старше 16 лет. Согласно используемой методике базовыми характеристиками качества трудового потенциала населения являются: физическое и психическое здоровье, когнитивный потенциал, творческие способности, коммуникабельность, культурный и нравственный уровень, потребность в достижении (социальные притязания). В результате математической обработки баз данных мониторинга каждое из перечисленных выше качеств получает численную оценку в виде индекса в интервале от нуля до единицы. Интегральный индекс - это качество трудового потенциала, иначе именуемое социальной дееспособностью.
} 
Исходные эмпирические данные содержат информацию о характере интеллектуального поведения (деятельности) и об отношении населения к ценностям интеллектуальной и творческой сферы [27, c. 30-33].

Вышесказанное позволяет выделить следующие уровни исследования интел- лектуального потенциала: микроуровень (личность), мезоуровень (предприятие, фирма) и макроуровень (общество; puc. 3).

Большинство авторов характеризуют сущность и содержание интеллектуального потенциала населения с позиции оценивания тенденций развития систем

\section{Рисунок 3. Уровни исследования интеллектуального потенциала населения (составлено автором)}

УРОВнИ

\begin{tabular}{|c|c|c|}
\hline & $\begin{array}{l}\text { ИНДИВИДУАЛЬНЫЙ } \\
\text { (МИКРОУРОВЕНЬ) }\end{array}$ & $\begin{array}{l}\text { Уровень образования человека } \\
\text { Источники пополнения знаний } \\
\text { Отношение к образованию, к знаниям } \\
\text { Оценка творческой деятельности человека } \\
\text { Отношение к творческой деятельности (изобретатель- } \\
\text { ству) }\end{array}$ \\
\hline 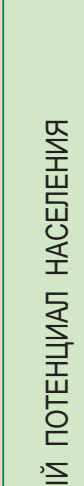 & $\begin{array}{l}\text { КОЛЛЕКТИВ, ОРГАНИЗАЦИЯ, } \\
\text { ПРЕДПРИЯТИЕ (МЕЗОУРОВЕНЬ) }\end{array}$ & $\begin{array}{l}\text { Уровень образования, профессиональной подготовки и } \\
\text { переподготовки } \\
\text { Уровень заработной платы работников (персонала) } \\
\text { Совокупность имеющихся интеллектуальных активов } \\
\text { (интеллектуальная собственность, база знаний) } \\
\text { Управленческий потенциал (идеология, формальные и } \\
\text { неформальные отношения внутри компании и с внешним } \\
\text { окружением } \\
\text { Уровень организационного развития (носители инсрор- } \\
\text { мации и методы ее распространения) } \\
\text { Элементы информационного (наличие информационной } \\
\text { системы и отлаженных инфоормационных потоков в } \\
\text { компании) и инновационного потенциалов компании }\end{array}$ \\
\hline 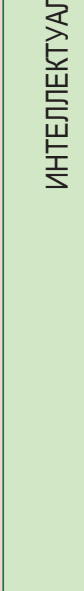 & $\begin{array}{l}\text { СТРАНА, РЕГИОН, } \\
\text { (МАКРОУРОВЕНЬ) }\end{array}$ & $\begin{array}{l}\text { Уровень общей образованности всего занятого населения } \\
\text { (среднее число накопленных лет обучения) } \\
\text { Удельный вес студенчества в населении } \\
\text { Доля расходов на образование в ВРП } \\
\text { Количество людей, имеющих ученую степень } \\
\text { Удельный вес занятых в ссрере науки и научного } \\
\text { обслуживания } \\
\text { Доля затрат на НИОКР } \\
\text { Численность аспирантов на } 10 \text { тыс. чел. населения } \\
\text { Количество патентных заявок на изобретения } \\
\text { Доля расходов на ИКТ в ВВП (ВРП) } \\
\text { Удельный вес организаций, использующих ИКТ } \\
\text { Удельный вес организаций, имеющих шеb-сайт в } \\
\text { Интернете } \\
\text { Публикации результатов исследований } \\
\text { Индекс цитируемости работ и т.д. }\end{array}$ \\
\hline
\end{tabular}

\section{СОСТАВ ИЗМЕРЯЕМЫХ КОМПОНЕНТОВ}

Уровень образования человека

Оценка творческой деятельности человека

Отношение к творческой деятельности (изобретатель-

Уровень образования, профессиональной подготовки

Совокупность имеющихся интеллектуальных активов Управленческий потенциал (идеология, формальные и 
образования, науки и культуры [6, с. 20, 22] как сфер формирования и реализации этого свойства. В этом случае используются показатели насыщенности указанных сфер исследуемой территории научными кадрами, удельные расходы на научные исследования и разработки как в целом, так и в расчете на одного исследователя, степень развитости материально-технической базы науки данной территории (страна, регион), что дает возможность определить не только текущее положение страны в мировом сообществе, но и вектор будущего экономического развития общества посредством создания соответствующей макроэкономической среды для повышения качества интеллектуальных ресурсов. Структура компонентов общественного интеллектуального потенциала позволяет определить сферы и субъекты жизнедеятельности региона (рис. 4), которые непосредственно участвуют в воспроизводстве интеллектуального потенциала, и конкретизировать основные направления управления воспроизводственным процессом.

При анализе и оценке учеными интеллектуального потенциала выделяются некоторые методологические различия в подходах. В одних исследованиях четко прослеживается ресурсный подход [9, с. 18 ; 10, с. 20]. Он исходит из посыла, что обще- ственный интеллектуальный потенциал является особой совокупностью ресурсов (материальных, природных, трудовых, финансовых, информационных) общественного производства и отражает способность национальной экономики технологически и коммерчески использовать научно-технические знания в целях социально-экономического развития.

Другие ученые (Л.С. Бляхман, Ф.Л. Мерсон, Э.М. Торф) использовали в своих трудах результативный подход, основанный на оценке «выхода» интеллектуальной деятельности [15, с. 56]. На макроуровне в этом случае анализируются финансовые результаты, полученные национальной экономикой от реализации товаров, содержащих объекты интеллектуальной собственности, на внешних рынках.

Во многих исследованиях ресурсный и результативный подходы комбинируются (Е.В. Бобкова, А.Г. Краюхин, Р.Е. Лещинер, В.К. Левашов, Ю.П. Лежнина, М.Н. Руткевич) [20, с. 45]. Оценка интеллектуального потенциала проводится в этом случае на основе интегрального показателя, агрегирующего и результаты интеллектуальной деятельности (объемы освоенных новшеств/реализованных нововведений), и ресурсы (износ основных фондов, оборачиваемость оборотных

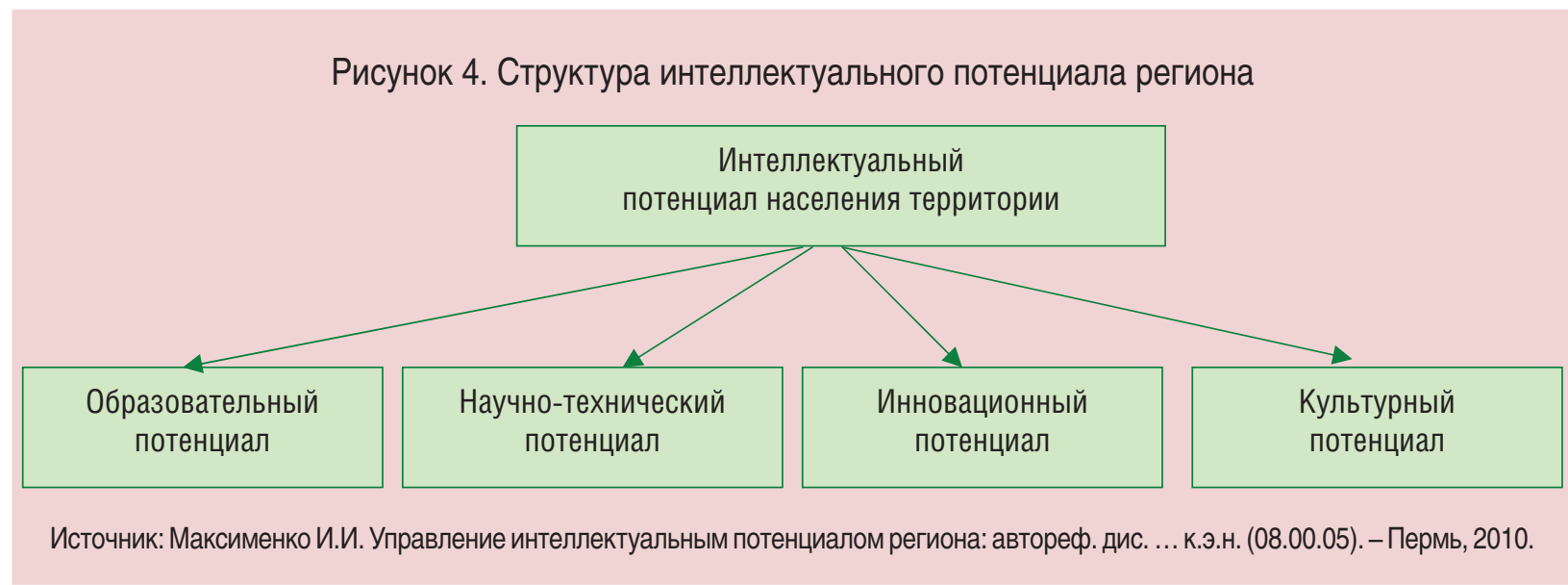


фондов, фондоотдача, доля заработной платы исследовательского персонала в себестоимости продукции). При таком подходе категория «интеллектуальный потенциал населения» понимается как мера эффективности экономики, выражающейся в ее способности к реализации интеллектуальных возможностей человека и общества в целях социально-экономического развития [17, с. 20].

Одним из методологических подходов к исследованию интеллектуального потенциала является тот, который основан на изучении социальной структуры общества [24, с. 19]. Его приверженцы выделяют в качестве носителя интеллектуального потенциала интеллигенцию. С одной стороны, интеллигенция действительно концентрирует в себе значительную часть интеллектуального потенциала, но, с другой стороны, сводить сущность исследуемого понятия лишь к творческой деятельности данной категории людей некорректно, так как в интеллектуальный потенциал включаются знания не только тех, кто занимается сложным умственным трудом, но и всего населения, выполняющего определенные экономические, социальные, политические, культурные функции.

При расширительном подходе интеллектуальные ресурсы рассматриваются весьма близко к категории «человеческий потенциал». И для этого имеются весомые аргументы, базирующиеся на международных методиках оценки и расчета индекса развития человеческого потенциала. В этом индексе, как известно, используются специально преобразуемые (для сопоставимости) по странам оценки уровня образования (грамотность) населения, здоровья (продолжительность жизни), результативности экономики (душевые доходы) [6, с. 15].
Оценки интеллектуального развития стран, принятые в международных исследованиях, включают, кроме ИРЧП, следующие методики. Во-первых, индекс экономики знаний, который показывает, насколько эффективно используются знания для обеспечения экономического развития. С помощью данного индекса измеряется способность страны к производству и распространению знаний на её территории. Индекс рассчитывается как среднее из оценок по четырем параметрам: экономические стимулы, институциональный режим, образование, инновации, использование информационных технологий.

Можно отметить и такой международный индикатор, как индекс глобальной конкурентоспособности (ИГК), компоненты которого объединены в 9 базисных групп ${ }^{4}$, одной из которых является «высшее образование и профессиональная подготовка» ${ }^{5}$.

Промежуточным уровнем между микро(человеком) и макроуровнем, соответствующим всему национальному хозяйству в целом, является измерение интеллектуального потенциала на уровне определенных профессиональных коллективов (компания, фирма, предприятие). В состав оценочных показателей при этом входят либо совокупность имеющихся интеллектуальных активов фирмы (интеллектуальная собственность, накопленные базы

\footnotetext{
4 Девять базисных групп: 1) институциональная среда, 2) состояние инфраструктуры, 3) макроэкономические показатели, 4) развитие здравоохранения и 5) начального образования, 6) высшее образование и профессиональное обучение, 7) эффективность рынка, 8) технологическая восприимчивость, 9) организация бизнеса и деловая практика.

5 При расчете индекса «высшее образование и профессиональная подготовка» учитывается не только доля населения с высшим и незаконченным высшим образованием, но и качество образования и науки в стране (при расчете индекса учитываются оценки бизнесом качества образовательной системы, уровень подготовки по математике и естественным наукам, качество организации школьного обучения).
} 
знаний, полезные отношения с другими субъектами (А.Ф. Мартынов) [16, с. 40], либо человеческий (квалификационные и творческие способности работников компании) и управленческий (управленческая идеология, формальные и неформальные отношения как внутри компании, так и с ее внешним окружением, уровень организационного развития и уровень развития каждого отдельного работника, информированность работников, носители информации и методы ее распространения) потенциалы, а также элементы информационного (наличие информационной системы и отлаженных информационных потоков в компании) и инновационного потенциалов компании [11, c. 1, 18].

Важнейшим составным элементом интеллектуального потенциала компании исследователи выделяют структурный капитал (интеллектуальная собственность, информационные системы, система финансовых взаимоотношений, положения, стандарты, награды). Главная функция данного потенциала - существенно ускорять прирост массы прибыли за счет формирования и реализации необходимых предприятию систем знаний и отношений [7, с. 13].

Анализ теоретико-методологических подходов показал, что при определении сущности интеллектуального потенциала населения большинством авторов не учитывается человек - носитель данного свойства.

Наш подход основывается на следующем толковании изучаемого понятия: «Интеллектуальный потенциал - это свойство населения определенной территории, заключающееся в способности людей к освоению знаний, их генерации и творческому созданию новых знаний, технологий, продуктов, обеспечивающих устойчивое расширенное и сбалансированное воспроизводство национального богатства, формирующегося при комплексном воздействии социально-экономических, социокультурных и научно-образовательных факторов». Следовательно, мы актуализируем такие обязательные для понимания категории элементы, как взаимосвязь с социально-экономическим развитием общества, факторы формирования свойства, в том числе необходимость подготовки (воспроизводства) интеллектуальных людей, психологический аспект (способности); при этом не игнорируются носители интеллектуального потенциала, поскольку это свойство населения. Такой подход с нашей точки зрения соответствует формированию интеллектуального потенциала населения в той среде, которую можно назвать инновационной, если в ней активно взаимодействуют все вышеперечисленные системы.

Сложность определения сущности и параметров интеллектуального потенциала обусловлена тем, что, с одной стороны, в нем наличествуют и выявленная, и невыявленная часть, с другой стороны, в нем сосредоточен широкий спектр абстрактных понятий: знания (теоретические, прикладные, экспериментальные), способности (умственные, творческие), интуиция. Кроме того, интеллектуальный потенциал населения динамично изменяется во времени под влиянием многих факторов: если он не используется, то быстро угасает, и, напротив когда практика предъявляет на науку активный спрос, он быстро растет, и еще быстрее растет эффективность его использования [14, с. 115].

Исследование интеллектуального потенциала населения, его состояния на данный момент - важная научная и практическая задача, которая может быть решена только при использовании междисциплинарного подхода. 
Выделенные нами в работе особенности исследования этой категории дают основания говорить о различиях, существующих в ее измерении: на макроуровне - на основе данных официальной статистики (больше это относится к общественному интеллектуальному потенциалу), на микроуровне - на основе эмпирических данных (ориентация в большей степени на оценку интеллектуального потенциала личности, при этом имеется существенное предпочтение - методология исследования позволяет оценить и интеллектуальный потенциал населения любой территории или компании) [13, с. 73].

Алгоритм оценки интеллектуального потенциала на микроуровне представляет собой систему процедур выявления эмпирических данных, последующей их математической обработки и сведения к общему интегральному показателю ${ }^{6}$. Индекс интеллектуального потенциала человека $\left(\mathrm{I}_{\text {ип }}\right)$ рассчитывается как среднее геометрическое индексов креативности $\left(\mathrm{I}_{\text {кр}}\right)$ и когнитивного ( $\mathrm{I}_{\text {зн }}$, знаниевого) потенциала:

$$
J_{\text {ип }}=\sqrt[2]{\mathrm{I}_{\text {кр }}+\mathrm{I}_{\text {зн }}}
$$

На основании сравнительного анализа методик нами была разработана собственная система показателей, комплексно характеризующих структурные элементы интеллектуального потенциала населения на макроуровне, - образовательный, научно-инновационный, культурный индексы.

Несмотря на традиционность этих показателей, в расчетах нами использованы новые подходы к их выбору, заключающиеся в фиксации не только результата интеллектуальной деятельности, но и условий для ее осуществления. Подход позволяет учесть синергетический эффект воспроизводства интеллектуального потенциала населения (табл. 3).

Для каждого индекса установлены фиксированные минимальные и максимальные значения. Минимальные значения определены как наименьшие возможные значения, которые могут быть достигнуты по данным показателям (в данном случае они приняты за 0), максимальные - как наибольшие по данным показателям отдельно в РФ, СЗФО за исследуемый период.

Таблица 3. Показатели, используемые для оценки интеллектуального потенциала населения

\begin{tabular}{|c|c|}
\hline Индекс & Показатель \\
\hline \multirow{3}{*}{ Образовательный } & Численность студентов вузов на 10 тыс. чел. экономически активного населения, чел. \\
\hline & Численность студентов средних учебных заведений на 10 тыс. чел. экономически активного населения, чел. \\
\hline & Доля расходов на образование, \% от ВРП (ВВП) \\
\hline \multirow{4}{*}{$\begin{array}{l}\text { Научно-инноваци- } \\
\text { онный }\end{array}$} & Доля затрат на НИОКР в ВРП (ВВП), \% \\
\hline & Число ученых и инженеров на 10 тыс. человек, чел. \\
\hline & Число жителей, подавших патентные заявки на 1 млн. человек, чел. \\
\hline & Число персональных компьютеров на 100 домохозяйств, ед. \\
\hline \multirow{4}{*}{ Культурный } & Библиотечный фонд, экз. на 1000 чел. \\
\hline & Посещаемость музеев, чел. на 1000 чел. \\
\hline & Посещаемость театров, чел. на 1000 чел. \\
\hline & Объем электронных каталогов библиотек, \% к общему объему фондов \\
\hline
\end{tabular}

6 Речь идет о мониторинге качества трудового потенциала (интеллектуальный потенциал населения - одно из качеств трудовых ресурсов). 
Значения образовательного ( $\left.\mathrm{P}_{\text {оп }}\right)$, научно-инновационного $\left(\mathrm{P}_{\text {нип }}\right)$ и культурного потенциалов $\left(\mathrm{P}_{\text {кп }}\right)$ рассчитываются как среднее арифметическое слагающих их коэффициентов, а интегральный индекс интеллектуального потенциала населения $\left(\mathrm{I}_{\text {ипн }}\right)$ рассчитывается в соответствии с формулой (2):

$$
\mathrm{I}_{\text {ипн }}=\frac{\mathrm{P}_{\text {ОП }}+\mathrm{P}_{\text {нип }}+\mathrm{X}_{\text {КП }}}{3},
$$

где:

$\mathrm{I}_{\text {ипн }}-$ интегральный индекс интеллектуального потенциала населения территории;

$\mathrm{P}_{\text {оп }}$ - индекс образовательного потенциала;

$\mathrm{P}_{\text {нип }}-$ индекс научно-инновационного потенциала;

$\mathrm{P}_{\text {кп }}$ - индекс культурного потенциала территории.

Введение в состав измеряемых компонентов показателей социокультурного развития территории позволяет оценить вклад в воспроизводство интеллектуального потенциала населения не только образовательной и научно-инновационной сфер, но и культуры как среды исторической преемственности и социального опыта людей.

Методика оценки интеллектуального потенциала населения на макроуровне (в т.ч. страны, федеральных округов, регионов) предусматривает возможность рейтингования территорий по данному индикатору, что позволяет обеспечить принятие качественных решений по улучшению условий формирования интеллектуальных свойств населения для каждого конкретного общества.

Описанный выше инструментарий оценки интеллектуального потенциала населения на макроуровне был использо- ван при исследовании интеллектуального развития территорий Северо-Западного федерального округа в период с 2000 по 2010 г. Анализ результатов показал, что в целом характеристики показывают слабую тенденцию к росту интеллектуального потенциала населения России на макроуровне.

Однако практически по всем показателям (кроме индекса культурного потенциала) Вологодская область отстает от РФ, особенно по значениям научно-инновационного индекса, которые в 2 раза ниже общероссийских $(0,19$ ед. против 0,38 по РФ). Все это наглядно свидетельствует, что в настоящий момент научно-технический потенциал не является главным источником социально-экономического развития российских территорий.

Данный методический инструментарий может быть использован для оценки интеллектуального потенциала населения как на уровне муниципальных образований, так и на уровне регионов и стран.

Интеллектуальный потенциал населения может выступать в качестве индикатора инновационного развития территорий, а также эффективности государственного управления. В этом случае он рассматривается как весы, на которых следует взвешивать различные политические, экономические и социальные акты. Когда на властных уровнях принимается какое-либо решение, то его можно оценивать с точки зрения того, в какую сторону повышения, снижения или даже уничтожения интеллектуального потенциала общества - оно работает.

Методологическим инструментом изучения интеллектуального потенциала служит мониторинг. Предлагаемая нами система мониторинга может быть рассмотрена как один из компонентов оце- 


\section{Рисунок 5. Схема проведения мониторинга интеллектуального потенциала} населения (составлено автором)

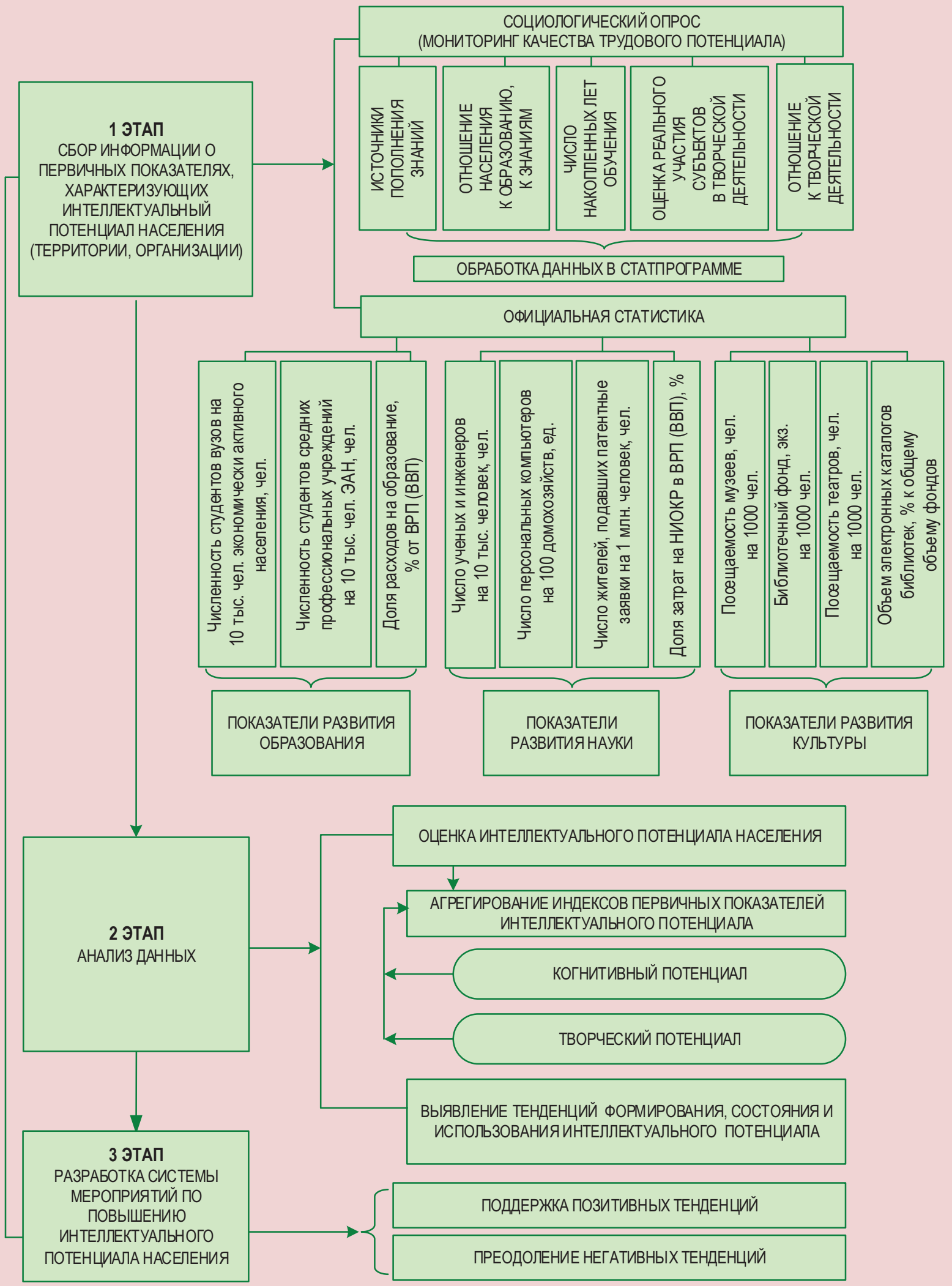


ночного исследования прямого и косвенного взаимного влияния экономики и социально-экономического развития области на интеллектуальный потенциал и интеллектуального потенциала населения на экономическое развитие региона в ближайшей и отдаленной перспективе. Мониторинг призван изучать и оценивать динамику состояния параметров интеллектуального потенциала, выявлять тенденции в его развитии (рис. 5).

Предусматривая одновременное изучение показателей, характеризующих интеллектуальный потенциал, и воздействующих на него факторов внешней среды, мониторинг позволяет решить следующие задачи:

1) организация наблюдения, получение достоверной и объективной информации об изменениях состояния интеллектуального потенциала региона;

2) оценка и системный анализ получаемой информации, выявление причин, вызывающих ухудшение интеллектуального потенциала;
3) подготовка рекомендаций органам власти и управления по преодолению негативных тенденций;

4) обеспечение органов управления информацией, полученной в ходе мониторинга.

Вместе с тем мониторинг служит информационной базой для решения таких задач, как:

- обоснование целей и приоритетов в региональной политике сохранения и повышения качества населения региона;

- подготовка докладов об итогах реализации политики сохранения и повышения качества населения или о человеческом развитии территорий;

- оценка результативности действий местных органов власти по решению поставленных задач в области интеллектуального развития общества.

Методологический инструментарий оценки интеллектуального потенциала населения может выступать одним из инструментов изучения эффективности государственного управления в условиях формирования общества знаний.

\section{Литература}

1. Аквинский, Ф. Сумма теологии / Ф. Аквинский. - Киев: Эльга, Ника-Центр, Эль-кор-МК, Экслибрис, 2002.

2. Багдасаров, М.И. Интеллектуальный капитал в системе корпоративных отношений: автореф. дис. ... к.с.н. / М.И. Багдасаров. - М., 2008.

3. Беккер, Г. Человеческое поведение: экономический подход / Г. Беккер // Избранные труды по экономической теории / сост. Р.И. Капелюшников. - М.: ГУ-ВШЭ, 2003.

4. Большая Советская Энциклопедия: в 30 т. - Т. 20 / под ред. А.М. Прохорова. - Изд. 3-е. - М.: Советская энциклопедия, 1975.

5. Зверева, Н.В. Человеческий потенциал устойчивого инновационного развития России [Электронный ресурс] / Н.В. Зверева. - Режим доступа: (дата: 10.02.2014 г.) http://igpr.ru/library/zvereva_nv_ chelovecheskij_otencial_ustojchivogo_innovacionnogo_razvitija_rossii

6. Ильин, В.А. Интеллектуальные ресурсы как фактор инновационного развития / В.А. Ильин, К.А. Гулин, Т.В. Ускова // Экономические и социальные перемены: факты, тенденции, прогноз. - 2010. - №3.

7. Клейнер, Г.Б. Предприятие в нестабильной экономической среде: риски, экономические стратегии, безопасность / Г.Б. Клейнер, В.А. Тамбовцев, Р.М. Качалов; под ред. С.А. Панова. - М.: Экономика, 1997.

8. Концепция долгосрочного социально-экономического развития Российской Федерации на период до 2020 года: утв. распоряжением Правительства Российской Федерации от 17 ноября 2008 г. №1662-р.

9. Кудина, М.В. Управление интеллектуальным потенциалом компании как элемент корпоративного управления / М.В. Кудина // Государственное управление: Электронный вестник. - 2010. - Вып. 22. Март. 
10. Лагутина, Л.Г. Управление интеллектуальным потенциалом региона в условиях формирующейся инновационной экономики: макроэкономический аспект: автореф. дис. ... к.э.н. / Л.Г. Лагутина. - М.: НОУ ВПО «Московский институт экономики, менеджмента и права», 2009.

11. Лайчук, О.В. Интеллектуально-информационный потенциал: вопросы теории и практики: монография / О.В. Лайчук, Л.А. Николаева. - Иркутск: Изд-во ВГУЭП, 2009.

12. Лежнина, Ю.П. Взаимосвязь социально-экономических показателей региона с интеллектуальным потенциалом его населения / Ю.П. Лежнина // Труды СГУ. - 2006. - Вып. 99 (Гуманитарные науки. Психология и социология образования).

13. Леонидова, Г.В. Направления оценки интеллектуального потенциала / Г.В. Леонидова // Федерализм. 2011. - №2.

14. Леонтьев, Б.Б. Цена интеллекта. Интеллектуальный капитал в бизнесе / Б.Б. Леонтьев. - М.: Издательский центр «Акционер», 2009.

15. Макрусев, В.В. Система трансграничной защиты интеллектуальной собственности: монография / В.В. Макрусев, А.А. Пауков. - М.: РТА, 2005.

16. Мартынов, А.Ф. Воспроизводство интеллектуального потенциала: оценка, моделирование, методология управления: автореф. ... Д.э.н. (08.00.05) / А.Ф. Мартынов. - М., 2008.

17. Марусинина, Е.Ю. Управление интеллектуальными ресурсами предприятия в рамках реализации концепции внутриорганизационного маркетинга: автореф. дис. ... к. э. н. / Е.Ю. Марусинина. - Волгоград, 2007.

18. Овсянников, А.А. Потенциал модернизации высшей школы России: коммуникации компетентностей профессуры и студенчества / А.А. Овсянников // Народонаселение. - 2011. - №4.

19. Основы политики РФ в области развития науки и технологий на период до 2020 года и дальнейшую перспективу: утв. Президентом РФ 11 января 2012 г. №Пр-83.

20. Регулирование инновационных процессов в регионе / под ред. Г.А. Краюхина. - СПб.: СПбГИЭА, 1997.

21. Римашевская, Н.М. Качество человеческого потенциала в современной России [Электронный ресурс] / H.M. Римашевская. - Режим доступа: http://spkurdyumov.narod.ru/Rimash1.htm.

22. Римашевская, Н.М. О методологии определения качественного состояния населения / Н.М. Римашевская // Демография и социология. - 1993. - Вып. 6.

23. Руткевич, М.Н. О понятии интеллектуального потенциала и способах его измерения / М.Н. Руткевич, В.К. Левашов // Науковедение. - 2000. - №1.

24. Сохань, А.В. Интеллектуальный потенциал личности / А.В. Сохань // Социальная структура социалистического общества. - М.: Наука, 1983.

25. Субетто, А.И. Россия и человечество на «перевале» истории в преддверии третьего тысячелетия / А.И. Субетто. - СПб.: ПАНИЛ, 1999.

26. Татаркин, А.И. Интеллектуальный ресурс общества / А.И. Татаркин // Вестник Российской академии наук. - 2011. - Т. 81. - №8.

27. Трудовой потенциал региона: состояние и развитие / В.А. Ильин, К.А. Гулин, Г.В. Леонидова, В.В. Давыдова. - Вологда: ВНКЦ ЦЭМИ РАН, 2004.

28. Чеботарев, Н.Ф. Инновационная деятельность как главный источник повышения благосостояния и развития человеческого капитала / Н.Ф. Чеботарев // Аудит и финансовый анализ. - 2007. - №2.

29. Шакирова, Д.М. Критерии оценки интеллектуального и образовательного потенциалов в информационном обществе / Д.М. Шакирова // Образовательные технологии и общество. - 2010. - Т. 13. - №3.

30. Шарден, П.Т. де. Феномен человека / П.Т. де Шарден. - М.: Прогресс, 1987.

31. Юдина, С. Оценка интеллектуальной составляющей национального трудового потенциала / С. Юдина, Г. Шарифуллина // Человек и труд. - 2010. - №4.

\section{References}

1. Tomas Aquinas. Summa Theologica. Kyiv: El'ga, Nika-Tsentr, El'-kor-MK, Ekslibris, 2002.

2. Bagdasarov M.I. Intellektual'nyy kapital v sisteme korporativnykh otnosheniy: avtoref. diss k. s. n. [Intellectual Capital in the System of Corporate Relations. Ph.D. in Sociology Dissertation Abstract]. Moscow, 2008. 
3. Becker G. Chelovecheskoe povedenie: ekonomicheskiy podkhod [The Economic Approach to Human Behavior]. Izbrannye trudy po ekonomicheskoy teorii [Selected Works on Economic Theory]. Compiled by R.I. Kapelyushnikov. Moscow: GU-VShE, 2003.

4. Bol'shaya Sovetskaya Entsiklopediya: v 30 t. T. 20 [The Great Soviet Encyclopedia: in 30 Volumes. Volume 20]. Ed. by A.M. Prokhorov. 3rd edition. Moscow: Sovetskaya entsiklopediya, 1975.

5. Zvereva N.V. Chelovecheskiy potentsial ustoychivogo innovatsionnogo razvitiya Rossii [Human Potential of Russia's Sustainable and Innovation Development]. Available at: http://igpr.ru/library/zvereva_nv_ chelovecheskij_ otencial_ustojchivogo_innovacionnogo_razvitija_rossii (accessed February 10, 2014)

6. Ilyin V.A., Gulin K.A., Uskova T.V. Intellektual'nye resursy kak faktor innovatsionnogo razvitiya [Intellectual Resources as Innovation Development Factor]. Ekonomicheskie i sotsial'nye peremeny: fakty, tendentsii, prognoz [Economic and Social Changes: Facts, Trends, Forecast], 2010, no.3.

7. Kleyner G.B., Tambovtsev V.A., Kachalov R.M. Predpriyatie v nestabil'noy ekonomicheskoy srede: riski, ekonomicheskie strategii, bezopasnost' [An Enterprise in the Unstable Economic Environment: Risks, Economic Strategies, Security]. Ed. by S.A. Panov. Moscow: Ekonomika, 1997.

8. Kontseptsiya dolgosrochnogo sotsial'no-ekonomicheskogo razvitiya Rossiyskoy Federatsii na period do 2020 goda: utv. rasporyazheniem Pravitel'stva Rossiyskoy Federatsii ot 17 noyabrya 2008 g. № 1662-r. [The Concept for SocioEconomic Development of the Russian Federation for the Period until 2020: Approved by the Resolution of the Government of the Russian Federation of November 17, 2008 No.1662-r].

9. Kudina M.V. Upravlenie intellektual'nym potentsialom kompanii kak element korporativnogo upravleniya [Management of Intellectual Potential of the Company as an Element of Corporate Management]. Gosudarstvennoe upravlenie: Elektronnyy vestnik [State Governance: Electronic Bulletin], 2010, no. 22, March.

10. Lagutina L.G. Upravlenie intellektual'nym potentsialom regiona v usloviyakh formiruyushcheysya innovatsionnoy ekonomiki: makroekonomicheskiy aspekt: avtoref. dis. k.e.n. [Management of Intellectual Potential of the Region in the Conditions of the Emerging Innovation Economy: Macroeconomic Aspect. Ph.D. in Economics Dissertation Abstract]. Moscow: NOU VPO “Moskovskiy institut ekonomiki, menedzhmenta i prava”, 2009.

11. Laychuk O.V., Nikolaeva L.A. Intellektual'no-informatsionnyy potentsial: voprosy teorii i praktiki: monografiya [Intellectual and Information Potential: Issues of Theory and Practice: Monograph]. Irkutsk: VGUEP Publ., 2009.

12. Lezhnina Yu.P. Vzaimosvyaz' sotsial'no-ekonomicheskikh pokazateley regiona s intellektual'nym potentsialom ego naseleniya [Interrelation between Socio-Economic Indicators of the Region and the Intellectual Potential of its Population]. Trudy SGU [Works of SGU], 2006, Issue 99 (Humanities. Psychology and Sociology of Education).

13. Leonidova, G.V. Napravleniya otsenki intellektual'nogo potentsiala [Directions of the Intellectual Potential Estimation]. Federalizm [Federalism], 2011, no.2.

14. Leont'ev B.B. Tsena intellekta. Intellektual'nyy kapital v biznese [Price of Intellect. Intellectual Capital in Business]. Moscow: Izdatel'skiy tsentr "Aktsioner", 2009.

15. Makrusev V.V., Paukov A.A. Sistema transgranichnoy zashchity intellektual'noy sobstvennosti: monografiya [The System of Cross-Border Protection of Intellectual Property: Monograph]. Moscow: RTA, 2005.

16. Martynov A.F. Vosproizvodstvo intellektual'nogo potentsiala: otsenka, modelirovanie, metodologiya upravleniya: avtoref. diss. d.e.n. [Reproduction of Intellectual Potential: Evaluation, Modeling, Management Methodology: Doctor of Economics Dissertation Abstract]. Moscow, 2008.

17. Marusinina E.Yu. Upravlenie intellektual'nymi resursami predpriyatiya v ramkakh realizatsii kontseptsii vnutriorganizatsionnogo marketinga: avtoref. diss. k. e. n. [Management of Intellectual Resources of the Enterprise within the Framework of Realization of the Corporate Marketing Concept. Ph.D. in Economics Economics Dissertation Abstract]. Volgograd, 2007.

18. Ovsyannikov A.A. Potentsial modernizatsii vysshey shkoly Rossii: kommunikatsii kompetentnostey professury i studenchestva [Modernization Potential of Higher Education in Russia: Communication of Competences of Academic Staff and Students]. Narodonaselenie [Population], 2011, no.4.

19. Osnovy politiki RF v oblasti razvitiya nauki i tekhnologiy na period do 2020 goda i dal'neyshuyu perspektivu: utv. Prezidentom RF 11 yanvarya $2012 \mathrm{~g}$. № Pr-83 [Fundamentals of the RF Policy in the Field of Development of Science and Technology for the Period until 2020 and Further Perspective: Approved by the President of the Russian Federation on 11 January 2012 No. PR-83]. 
20. Regulirovanie innovatsionnykh protsessov v regione [Regulation of Innovation Processes in the Region]. Ed by. G.A. Krayukhin. Saint Petersburg: SPbGIEA, 1997.

21. Rimashevskaya, N.M. Kachestvo chelovecheskogo potentsiala v sovremennoy Rossii [Elektronnyy resurs] / N.M. Rimashevskaya. - Rezhim dostupa: http://spkurdyumov.narod.ru/Rimash1.htm.

22. Rimashevskaya, N.M. O metodologii opredeleniya kachestvennogo sostoyaniya naseleniya / N.M. Rimashevskaya // Demografiya i sotsiologiya. - 1993. - Vyp. 6.

23. Rutkevich, M.N. O ponyatii intellektual'nogo potentsiala i sposobakh ego izmereniya / M.N. Rutkevich, V.K. Levashov // Nau-kovedenie. - 2000. - № 1.

24. Sokhan', A.V. Intellektual'nyy potentsial lichnosti / A.V. Sokhan' // Sotsial'naya struktura sotsialisticheskogo obshchestva. - M.: Nauka, 1983.

25. Subetto, A.I. Rossiya i chelovechestvo na «perevale» istorii v preddverii tret'ego tysyacheletiya / A.I. Subetto. - SPb.: PANIL, 1999.

26. Tatarkin, A.I. Intellektual'nyy resurs obshchestva / A.I. Tatarkin // Vestnik Rossiyskoy akademii nauk. - 2011. - T. 81. - № 8 .

27. Trudovoy potentsial regiona: sostoyanie i razvitie / V.A. Il'in, K.A. Gulin, G.V. Leonidova, V.V. Davydova. Vologda: VNKTs TsEMI RAN, 2004.

28. Chebotarev, N.F. Innovatsionnaya deyatel'nost' kak glavnyy istochnik povysheniya blagosostoyaniya i razvitiya chelovecheskogo kapitala // Audit i finansovyy analiz. - 2007. - №2.

29. Shakirova, D.M. Kriterii otsenki intellektual'nogo i obrazovatel'nogo potentsialov v informatsionnom obshchestve / D.M. Shakirova // Obrazovatel'nye tekhnologii i obshchestvo. - 2010. - T. 13. - № 3.

30. Sharden, P.T. de. Fenomen cheloveka / P.T. de Sharden. - M.: Progress, 1987.

31. Yudina, S. Otsenka intellektual'noy sostavlyayushchey natsional'nogo trudovogo potentsiala / S. Yudina, G. Sharifullina // Chelovek i trud. - 2010. - №4. 


\section{ОТРАСЛЕВАЯ ЭКОНОМИКА}

УДК 338.12, 338.012, ББК 65.3

(C) Беркович М.И., Комарова Е.А.

\section{Отраслевой анализ в контексте эволюционного развития экономических систем}

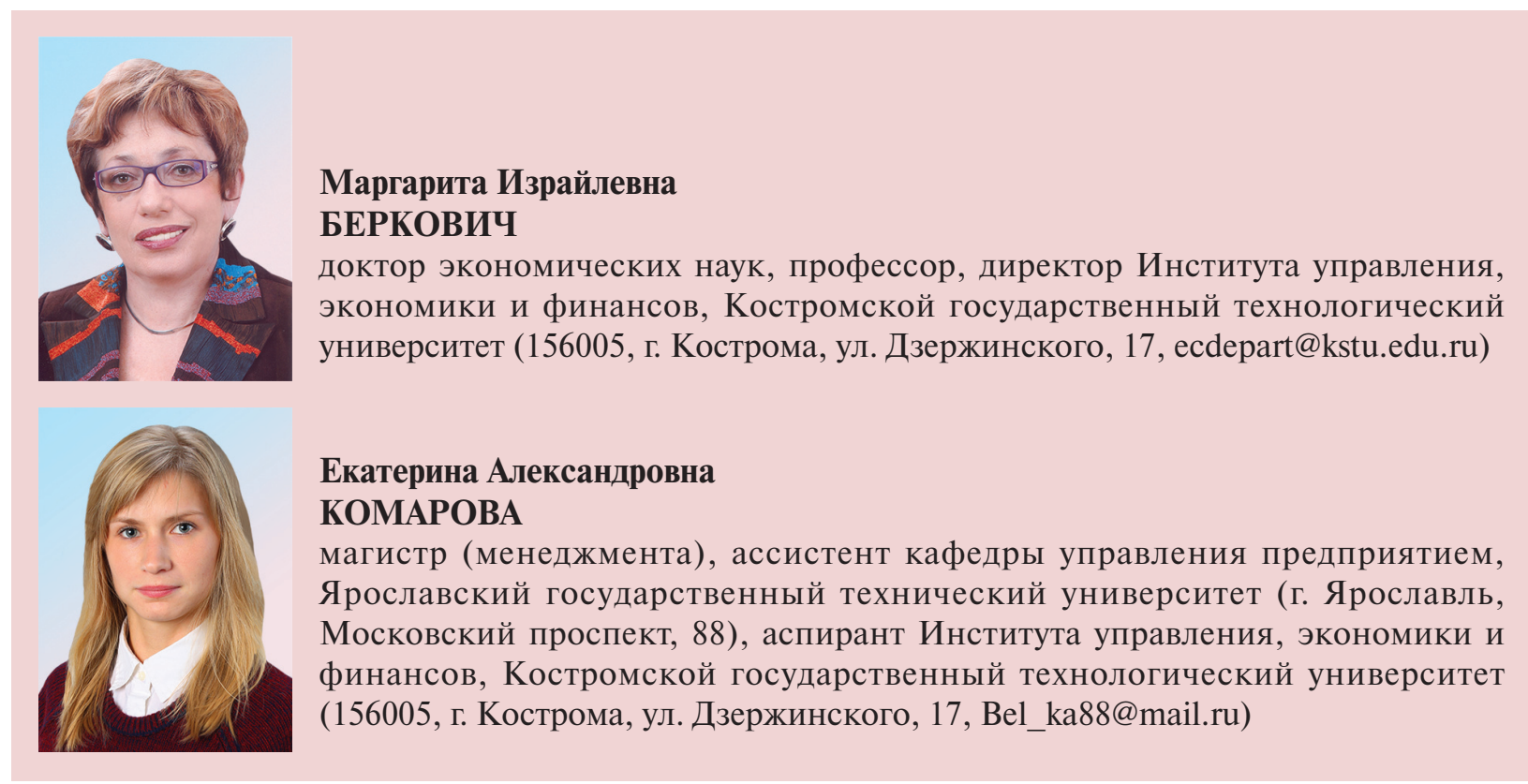

Аннотация. Реформирование российской экономики требует особого внимания к долгосрочным проблемам ее развития с тем, чтобы придать ему устойчивый целенаправленный характер. Необходимость повышения социальных и экономических параметров и комплексного инновационного развития территориальных систем хозяйствования требует выработки обоснованной политики и стратегии регионов в отношении отраслей, формирующих их потенциал. В статье предложен подход к реформированию отраслей народного хозяйства на основе анализа их жизненного цикла и выделения функциональных особенностей отдельной мезоэкономической системы. Целью настоящего исследования является выделение ключевых параметров развития отраслей на уровне региона. Эволюционный подход, заложенный в основу методики, позволяет определить факторы, оказывающие наибольшее влияние на динамику жизненного цикла. Выделены следующие основные группы факторов: ресурсы, продукт, технологии, рынок, банковский сектор, государственная политика. На основе анализа жизненных циклов отраслей химической промышленности Ярославского региона (производство синтетического каучука и производство технического углерода) сделан вывод о том, что единственный путь устойчивого развития отраслей - непрерывное внедрение инноваций, процесс, подверженный влиянию цикличности и обусловленный воздействием факторов экзогенной и эндогенной природы.

Ключевые слова: экономическая система; отрасль; жизненный цикл отрасли; эволюционное развитие; циклообразующие факторы; инновации. 
Berkovich M.I., Komarova E.A.

\section{Branch analysis in the context of evolutionary development of economic systems}

Berkovich Margarita Izraylevna - Doctor of Economics, Professor, Director of the Institute of Management, Economics and Finance, Kostroma State University of Technology (17, Dzerzhinsky Street, Kostroma, 156005, Russia,Bel_ka88@mail.ru)

Komarova Ekaterina Aleksandrovna - M.A. in Management, Teaching Assistant at the Department of Business Administration, Yaroslavl State Technical University (88, Moskovsky Avenue, Yaroslavl), Graduate Student at the Institute of Management, Economics and Finance, Kostroma State University of Technology (17, Dzerzhinsky Street, Kostroma, 156005, Russia, Bel_ka88@mail.ru)

Abstract. Upgrading of Russian economy claims special attention to long-term problems of its development in order to make it stable and purposeful. The necessity to improve social and economic parameters and comprehensive innovation development of territorial economic systems requires elaboration of sound policy and regions' strategies in relation to regional branches that form their potential. The article proposes an approach to reform national economic sectors on the basis of their life cycle analysis and allocation of functional features of a single mesoeconomic system. The research is aimed at selecting key parameters of sectors' development at the regional level. The evolutionary approach that serves as the basis for the methodology gives an opportunity to determine the factors that have the greatest impact on life cycle dynamics. The article singles out the following main groups of factors: resources, product, technology, market, banking sector, public policy. By analyzing life cycles of the Yaroslavl region's chemical industries (synthetic rubber and carbon black production) it is concluded that the only way to ensure sustainable development of branches lies in the continuous implementation of innovations, a process affected by cyclicity and determined by factors of exogenous and endogenous nature.

Key words: economic system; branch; life cycle of a branch; evolutionary development; cycle-formative factor; innovations.

Исследование любой системы предполагает определение общих тенденций, трендов её развития. Такой подход особенно актуален для экономических систем, динамичность которых резко возросла в последнее время.

Считается, что одним из парадоксов современного постиндустриального общества является отсутствие связи фундаментальной экономической науки с бизнесом и его потребностями - практика современного экономического развития значительно обогнала уровень теоретических обобщений и рекомендаций [4, с. 8].

Дисбаланс между теорией и практикой свидетельствует о необходимости проведения более глубоких исследований предпо- сылок развития экономических систем различного уровня, в том числе на основе теорий жизненного цикла, поскольку это создаст возможность большей обоснованности необходимых преобразований. В настоящее время концепция жизненных циклов в экономической науке носит преимущественно описательный характер - в практической деятельности применение модели жизненных циклов довольно ограничено.

Концепция жизненного цикла возникла в конце XIX в. как комплекс идей, включающий в себя изучение закономерностей наследственности и развития. В экономических науках наибольшее распространение получила концепция жизненного цикла продукта (товара). 
Ж.Ж. Ламбен, известный специалист в области маркетинга, описывает суть этой концепции следующим образом: «Потенциал рынка определяет масштаб экономической возможности, которую предоставляет рынок товара. Эта первая, по своей сути количественная, мера привлекательности должна быть дополнена динамической оценкой, характеризующей ее продолжительность, т.е. эволюцию потенциального спроса во времени» [3].

Если расширить границы применения концепции, описанной Ж.Ж. Ламбеном, то можно говорить об отрасли, как о некотором экономическом пространстве, где товары не только продаются, но именно производятся. При проведении анализа целесообразно дополнять «рыночные» параметры (ёмкость рынка, масштабы конкуренции, уровень концентрации) динамическими характеристиками, к которым могут быть отнесены стадия жизненного цикла отрасли, возможные темпы роста прибыли, скорость технологических изменений. Такой подход связан также с трансформацией самой цели анализа отрасли, в качестве которой следует принять не только оценку положения дел в отдельном производстве на данный момент, а составление на основе этих данных прогноза её развития.

По сути, теория жизненного цикла отрасли является продолжением идеи циклического развития экономической конъюнктуры, описанной в трудах классиков - Дж.М. Кейнса, Н.Д. Кондратьева, Й. Шумпетера. Цикличность представляет собой естественный способ развития экономики, всеобщую форму движения, которая отражает неравномерность протекания экономических процессов.

Ещё в XIX веке экономическая наука выделила цикл 7-12 лет, который впоследствии получил имя К. Жуглара (18191905 гг.), внесшего большой вклад в изуче- ние природы промышленных колебаний во Франции, Великобритании и США, на основе фундаментального анализа колебания ставок процента и цен. В результате проведённых им исследований было выявлено, что эти колебания совпали с циклами инвестиций, которые, в свою очередь, инициировали изменения валового продукта, инфляции и занятости. В литературе этот цикл имеет также названия «бизнес-цикл», «промышленный цикЛ», «средний цикл».

Современные исследователи, специалисты по стратегическому менеджменту, обращают особое внимание на взаимосвязь четырех циклов развития: экономического цикла, отраслевого цикла, цикла развития предприятия (фирмы) и жизненного цикла товара. По их мнению, циклы более низкого уровня как бы «вкладываются» в качестве составных частей в циклы более высокого уровня и, таким образом, в существенной мере определяют характеристики последних [7, с. 182]. Хотя, конечно, цикл развития более высокого уровня определяет собой новое системное качество и не является простой суммой сложения циклов более низкого уровня.

В этих положениях обнаруживает себя системный подход к изучению экономических явлений, однако в данном случае система довольно сложная и обладает некоторыми особенностями. Во-первых, безусловным остаётся влияние циклов одного уровня на циклы других уровней, но важно отметить и возможность разнонаправленности этого влияния. Действительно, рост национального хозяйства не означает увеличения объемов производства всех отраслей промышленности; с другой стороны, расширение масштаба отдельных, в том числе базовых, отраслей имеет следствием положительную динамику на макроэкономическом уровне. 
Более того, реакция отдельных отраслей на изменение внешней среды может быть различной не только по величине, но и по вектору - одно и то же воздействие извне может иметь диаметрально противоположные следствия для разных отраслей. Так, если рост цен на нефть положительно скажется на динамике добывающих отраслей, то предприятия, занимающиеся грузоперевозками, например, будут испытывать затруднения, связанные с ростом цен на конечный продукт переработки нефти топливо.

Колебания различных циклов формируются не только под влиянием внешних воздействий. Влияние изнутри, изменение отдельной части экономической системы на определённом уровне может изменить динамику системы, задавая иную траекторию движения в рамках жизненного цикла. В основе таких изменений лежат обычно процессы внедрения инноваций.

Наиболее известный анализ жизненного цикла отрасли принадлежит основателю школы позиционирования М. Портеру. Особенность его исследований состоит том, что он впервые подробно рассмотрел все стадии жизненного цикла с позиции конкурентной динамики на основе таких структурных характеристик, как число и размер фирм, уровень технологической и стратегической неопределённости, издержки, цены, покупатели, характеристики конкурентов и интенсивность конкуренции.

По мнению М. Портера, хотя изначальная структура, производственный потенциал и инвестиционные решения конкрентных фирм носят специфический для каждой отрасли характер, тем не менее, можно выделить в общем виде важнейшие эволюционные процессы. В каждой отрасли происходят в той или иной форме определённые предсказемые (и взаимодействующие) динамические процессы, несмотря на то, что их скорость и направ- ления различны в зависимости от отрасли [8, с. 217]. К таким процессам относятся долгосрочные изменения темпов роста, уровня неопределённости, конкурентной ситуации, стоимости исходных ресурсов и валютных курсов, структурные сдвиги в смежных отраслях.

Концепция жизненного цикла служит в качестве «упрощённой модели», первоосновы анализа экономических явлений. Использование таких теорий, получивших название моделей, целесообразно постольку, поскольку позволяет отвлечься от несущественных деталей и выявить принципиальные экономические связи в эволюции экономической системы [5, с. 49].

Эволюция как направленное изменение любого процесса, системы, предмета, имеющего необратимый характер, всегда происходит в реальном (динамическом или историческом) времени. В более широком смысле термин «эволюционный» включает изучение процессов долгосрочных поступательных изменений [6, с. 28].

Научное обоснование перспектив развития отдельных отраслей предполагает выделение специфических факторов внешней среды, оказывающих на них наибольшее влияние, с учётом особенностей жизненного цикла конкретных производств.

На уровне регионов отрасли развиваются в сравнимых условиях, под влиянием схожих факторов финансового, институционального, демографического характера. Для того чтобы сделать вывод о стадии жизненного цикла, на которой находится отрасль и выявить направления изменений для недопущения спада или удержания стадии роста, необходимо проведение детального анализа этих факторов.

Для этих целей выделены следующие группы факторов, представленные в таблище: ресурсы; продукт; технологии; рынок; банковский сектор; государственная политика. 
Основные фракторы, оказывающие влияние на стадии жизненного цикла отраслей

\begin{tabular}{|c|c|}
\hline Группа фракторов & Факторы \\
\hline \multirow[t]{4}{*}{ Ресурсы } & Сырьё (стоимость сырья, доступность ресурсов) \\
\hline & Труд (наличие трудовых ресурсов, средний уровень оплаты труда в регионе) \\
\hline & Капитал (десицит капитала ведёт к замедлению темпов роста) \\
\hline & Информация (спрос, ситуация в смежных отраслях и т.д.) \\
\hline \multirow[t]{3}{*}{ Технологии } & Темпы технологических изменений (быстрая или замедленная смена технологий производства) \\
\hline & Квалифрикация кадров (потребность отрасли в работниках определённого уровня подготовки) \\
\hline & Лёгкость вхождения и выхода из отрасли (входные и выходные барьеры) \\
\hline \multirow[t]{3}{*}{ Продукт } & Направления и темпы продуктовых инноваций \\
\hline & $\begin{array}{l}\text { Степень диффреренциации продукта (узкоспециализированные или широкономенклатурные } \\
\text { производства) }\end{array}$ \\
\hline & $\begin{array}{l}\text { Импортозамещение (уникальность продукции на мировом рынке, конкуренция со стороны } \\
\text { иностранных производителей) }\end{array}$ \\
\hline \multirow[t]{2}{*}{ Рынок } & $\begin{array}{l}\text { Размеры и темпы роста рынка (потенциальный размер рынка и темпы его роста в краткосрочном, } \\
\text { среднесрочном и долгосрочном периодах) }\end{array}$ \\
\hline & $\begin{array}{l}\text { Масштабы конкуренции и конкурентная ситуация (конкуренция на местном, региональном, мировом } \\
\text { уровне; монополия, олигополия и т.д.) }\end{array}$ \\
\hline \multicolumn{2}{|c|}{ Банковский сектор (доступность и стоимость кредитных ресурсов) } \\
\hline \multicolumn{2}{|c|}{ Государственная политика (меры государственной поддержки, ввозные и экспортные пошлины, налоговые послабления и др.) } \\
\hline
\end{tabular}

Поскольку циклический характер развития экономики связан с действием разнообразных причин, имеющих как эндогенную, так и экзогенную природу, то очевидна необходимость детального исследования, так называемых, циклообразующих факторов. При этом важно оценить не только характер влияния отдельных факторов, но и различные варианты динамики отрасли при изменении отдельных факторов (при изменении в соотношениях влияния факторов стадия жизненного цикла сдвигается), а также общий синергетический эффект.

Традиционная модель жизненного цикла отрасли, предлагаемая большинством исследователей, включает четыре стадии развития: вновь возникшая отрасль, растущая отрасль, зрелая отрасль и отрасль в состоянии упадка, или кризиса, но, с учетом влияния на эволюцию отрасли всех вышеназванных факторов, вид данной кривой может значительно изменяться.

Р. Грант, комментируя традиционную $\mathrm{S}$-образную кривую жизненного цикла, поясняет, что отрасли различаются по моделям развития. Отрасли, обеспечиваю- щие базовые потребности - строительство жилья, обработка продуктов питания и изготовление одежды, возможно, никогда не войдут в стадию спада, потому что устаревание таких потребностей маловероятно. Некоторые отрасли могут претерпевать омоложение в процессе жизненного цикла (индустрия мотоциклов). Кроме того, в разных странах (или даже в разных регионах) отрасли могут находиться на разных стадиях своего жизненного цикла (например, автомобильный рынок) [1, с. 304].

Для того чтобы исследовать жизненный цикл, необходимо оценить границы применения термина «отрасль». Н.М. Розанова дает определение отрасли как совокупности производителей товаров, отличающихся технологической близостью в производстве (структура с точки зрения предложения), отличая его от понятия рынка: рынок - совокупность продавцов товаров-заменителей (структура с точки зрения спроса) [11, с. 29].

Н.В. Пахомова и К.К. Рихтер предлагают применять термин «отрасль» по отношению к группе фирм, производящих и продающих взаимозаменяемые (в про- 
изводстве) продукты с использованием сходной технологии и оборудования конкретного рынка факторов производства [9, c. 149].

На практике же термин «отрасль» сейчас заменяется понятием «вид экономической деятельности», что вносит некую неопределённость в понятийный аппарат. Хотя дефиниции «отрасль» нет в статистической отчётности, но термины «отраслевая принадлежность», «отраслевая структура» активно используются и в научных публикациях, и в практической деятельности.

Детальное изучение видов экономической деятельности позволяет выявить, что отдельные производства в пределах одного раздела ОКВЭД существенно различаются по своим экономическим характеристикам, уровню конкуренции и перспективам развития, по темпам технического прогресса, по размерам рынков и другим параметрам, что важно учитывать при формировании стратегии развития отраслей национальной экономики, регионов и отдельных предприятий.

В частности, если анализировать ВЭД «химическое производство» в Ярославской области, можно наблюдать серьёзное различие среди таких групп, как производство удобрений и азотных соединений, производство синтетического каучука, производство красок и лаков, производство фармацевтической продукции и т.Д. Для того чтобы проследить разницу жизненных циклов на примере, рассмотрим две отрасли: производство синтетического каучука (код по ОКВЭД 24.17) и производство технического углерода (сажи) (входит в код 24.66 - Производство прочих химических продуктов). Данные отрасли используют сырьё, схожее по своему происхождению - отходы нефтепереработки, и работают, по сути, на одного потребителя - автомобильную промышленность с той разницей, что завод СК (синтетического каучука) был закрыт несколько лет назад, а завод по производству технического углерода в настоящее время - стабильно развивающееся производство.

Завод Синтетического каучука № 1 (ныне Акционерное общество «СК Премьер»), построенный в 1932 году, - завод, где был получен первый в мире искусственный каучук, который был необходим для производства автопокрышек [12]. В дальнейшем был найден оптимальный вариант технологического процесса - производство каучука резко возросло, снизилась себестоимость. В послевоенное время производство развивалось и совершенствовалось. С пуском Ярославского нефтеперерабатывающего завода СК-1 реконструировался. Использование газов, получающихся при переработке нефти, позволило организовать на нем в широком масштабе производство синтетического спирта, метилстирола и других видов сырья для предприятий химической промышленности [10].

В начале семидесятых годов специалистами завода был разработан процесс получения одного из так называемых «жидких» каучуков. Этапным моментом в истории завода можно считать пуск крупнотоннажного производства изопренового каучука СКИ-3 - полноценного заменителя натуральных каучуков. В кратчайший срок было освоено высокоавтоматизированное производство нового сырья для шинной и других отраслей промышленности. Однако в 1993 году комплекс СКИ-3 в Ярославле оказался без сырья. Начался спад во всей промышленности страны, рушились экономические связи между производителями и потребителями в бывших союзных республиках. К 1996 году в стране достигла апогея эпидемия неплатежей и бартерных сделок. Новое руководство решило сделать упор на выпуск клеев, шпаклевок, ранее подсобных производств. Последствием этого шага стало то, что более предпри- 
имчивые конкуренты вытеснили ярославский завод с рынка каучуков и латексов. В 2001 году на завод пришёл новый инвестор OАО «Группа Альянс», специализирующаяся на антикризисном управлении. По заявлениям руководства, планировалось на существующих мощностях за счет их реконструкции и модернизации освоить продукцию нового качества и ассортимента, выйти с ней на отечественный и зарубежный рынок [13].

Основной областью применения синтетических каучуков в РФ, как и в ведущих зарубежных странах, является производство шин.

По мнению аналитиков, несмотря на определенные трудности в развитии и непрекращающийся передел собственности, производство синтетического каучука остается весьма перспективным для России. Удельный вес России в мировом производстве СК составляет 7\%, что значительно выше аналогичной доли других полимеров. Огромный производственный опыт в этой области и большой авторитет российского синтетического каучука на мировом рынке дают основание предполагать, что достаточно сравнительно небольших усилий для того, чтобы российское производство СК вновь заняло лидирующие позиции в мире [14].

Безусловно, в период 1990-х годов все заводы СК страны столкнулись с нехваткой сырья и необходимостью модернизации производства. Однако, в целом по стране, нельзя сказать, что отрасль по производству синтетического каучука находится в стадии спада. Например, в ОАО «Воронежсинтезкаучук», также одном из первых в мире предприятий-производителей синтетических каучуков и латексов, сегодня освоен выпуск новых марок каучуков по программе «Зеленая шина». Запушенное на заводе в 1991 году серийное производство бутадиен-стирольных термоэластопластов по настоящее время является единственным в СНГ, объем выпуска данного вида продукции постоянно растет, около $50 \%$ составляют экспортные поставки.

Проблемой большинства заводов по производству синтетического каучука является их местонахождение в глубине европейской части страны, в том числе в Центральной России, трудности для них существуют не только при транспортировке сырья, но и при вывозе самих каучуков за пределы страны. Каучук в Юго-Восточной Азии значительно дороже, чем в Европе, но довезти его туда непросто. Для предприятий Урало-Поволжья, где выпускается две трети российского каучука, проблема экспортной логистики стоит еще острее. Во многом именно из-за логистического барьера российские экспортеры ориентируются в основном на европейский, а не на более интересный азиатский рынок. Эксперты считают, что при наличии инвестиций и желания даже с имеющейся сырьевой базой в России выпуск этилена легко может быть увеличен вдвое, до 4 млн. тонн [15].

Что же касается завода СK-1 в Ярославле, то в 2000-х годах он фактически попал под контроль группы «Сибур», налаживающей производство полного цикла. Далеко идущие планы осуществлены не были, завод оказался лишним в производственной цепочке, вследствие чего в настоящее время прекратил свою работу.

Таким образом, несмотря на свою громкую историю, жизненный цикл отрасли по производству синтетического каучука в Ярославском регионе завершен, тогда как в целом по стране отрасль находится на стадии зрелости и имеет все возможности вновь превратиться в растущую. Условиями для успешной работы являются постоянная модернизация производства, перспективные научные разработки и грамотное управление. 
Важность соблюдения этих условий подтверждается темпами развития отрасли по производству технического углерода (сажи), представленной в регионе заводом «Ярославский технический углерод» (ОАО «ЯТУ»), занимающим лидирующие позиции в России и на мировом рынке. Мощность предприятия составляет более 200 тысяч тонн технического углерода в год.

Технический углерод применяется в качестве усиливающего компонента в производстве резин и других пластических масс. Спрос на технический углерод в России с 2007 по 2011 год вырос на 25,7\%. Больше половины всего выпускаемого технического углерода используется в производстве шин и резинотехнических изделий. Российский рынок технического углеводорода является экспортно-ориентированным. В 2007-2011 годах в среднем более $60 \%$ от общего объема спроса приходилось на экспорт [16].

ОАО «ЯТУ» экспортирует более $80 \%$ производимой продукции в страны Европы и Америки, Азии и Африки. Постоянными потребителями продукции ОАО «Ярославский технический углерод» являются такие известные производители шин и резинотехнических изделий, как Goodyear, Michelin, Continental, Nokian, Trelleborg, Semperit. Сейчас предприятие входит в пятерку крупнейших в мире заводов - производителей технического углерода.

Строительство Ново-Ярославского сажевого завода было начато в 1962 году. Первоначально строительство осуществлялось как сажевое производство при НовоЯрославском нефтеперерабатывающем заводе. С 6 мая 1963 года сажевое производство было выделено из состава нефтеперерабатывающего завода в самостоятельное предприятие. С 3 декабря 1974 года оно было переименовано в Ново-Ярославский завод технического углерода, с 1992 года акционерное общество открытого типа «Ярославский технический углерод» [17].
К концу 80-х годов на заводе работало 12 технологических потоков, где выпускалось до 150 тонн технического углерода в год. В 1993 году на предприятии впервые в отрасли была внедрена система замкнутого водооборота за счет реконструкции очистных сооружений и полного прекращения сброса воды в близлежащие водоемы. Даже в условиях кризиса предприятие в 1994 году одним из первых в России наладило выпуск марок технического углерода согласно классификации ASTM. В 2000 году управление технологическими потоками было полностью компьютеризировано.

В 2001 году введена в эксплуатацию собственная электростанция. Весь отходящий газ производства технического углерода сжигается в котлах-утилизаторах, а выработанный пар перерабатывается на парогенераторах в электроэнергию в количестве, покрывающем полную потребность предприятия [18].

Из приведённых данных становится ясно, что ввиду постоянного обновления и модернизации отрасль по производству технического углерода в Ярославской области уже долгое время находится на стадии роста и, несмотря на схожие с отраслью по производству синтетического каучука проблемы, успешно функционирует и развивается.

В любом случае, существует множество вариантов действий, которые можно предусмотреть в ходе стратегического и тактического планирования в целях успешного функционирования предприятия в конкретной отрасли. Но современный путь развития всех без исключения отраслей предполагает единственную возможность для стабильного роста - постоянное внедрение инноваций.

Исследования динамики внедрения инноваций лишь подтверждают адекватность циклического подхода. В ряде работ по инновационному менеджменту иссле- 
дована взаимосвязь отдельных циклов развития инноваций, логика и динамика перехода от одного цикла к другому. При этом отмечается, что новый цикл продуктовых и процессных инноваций, как и в любой циклической модели, может начаться под воздействием не только внутренних отраслевых факторов технологического развития (эндогенные процессы), но и внешних по отношению к отрасли факторов, «сотрясений среды», не зависящих от конкретной отрасли (экзогенные процессы).

Считается, что суть достижений экономической науки прошлого века заключа- ется в том, что экономическая система: a) принципиально циклична; б) в основе этой цикличности лежит периодическое масштабное обновление капитала, котоpoe, начавшись в наиболее приспособленных секторах, вызывает экономический рост всей экономической системы [2, с. 18].

Дальнейшее развитие теории жизненного цикла экономических систем, в том числе на мезоуровне, безусловно, позволит обеспечить более активный переход экономики страны на инновационный путь устойчивого функционирования.

\section{Литература}

1. Грант, Р.М. Современный стратегический анализ / Р.М. Грант; 5-е изд.; пер. с англ. под ред. В.Н. Фунтова. - СПб.: Питер, 2008. - 560 с.

2. Гурова, Т. Эти двое и экономический рост / Т. Гурова, А. Ивантер // Эксперт. - Вып. 26(857). 2013. - C. 14-18.

3. Ламбен, Ж.-Ж. Менеджмент, ориентированный на рынок / Ж.-Ж. Ламбен. - СПб.: Питер, $2007 .-800$ с.

4. Лебедев, О.Т. Экономика отраслевых рынков: учебное пособие / О.Т. Лебедев. - М.: Бослен, 2008. - 528 с.

5. Мэнкью, Н.Г. Макроэкономика: пер. с англ. / Н.Г. Мэнкью. - М.: Изд-во МГУ, 1994. - 736 с.

6. Нельсон, Ричард Р. Эволюционная теория экономических изменений: пер. с англ. / Ричард Р. Нельсон., Сидней Дж. Уинтер. - М.: Дело, 2002. - 536 с.

7. Стратегический менеджмент / под ред. А.Н. Петрова. - СПб.: Питер, 2005. - 496 с.

8. Портер, М. Конкурентная стратегия: Методика анализа отраслей и конкурентов / М. Портер; пер. с англ. - 4-е изд. - М.: Альпина Паблишер, 2011. - 453 с.

9. Розанова, Н.М. Экономика отраслевых рынков: учебное пособие / Н.М. Розанова. - М.: Издательство Юрайт, 2010. - 906 с.

10. Рязанцев, Н.П. История Ярославского края (1930-2005 гг.): учебное пособие для учащихся средних общеобразовательных учебных заведений / Н.П. Рязанцев, Ю.Г. Салова. - Ярославль, Рыбинск: Б/и, Рыбинский Дом печати, 2005. - 277 с.

11. Пахомова, Н.В. Экономика отраслевых рынков и политика государства: учебник / Н.В. Пахомова, К.К. Рихтер. - М.: ЗАО «Издательство «Экономика», 2009. - 815 с.

12. Государственный архив Ярославской области [Электронный ресурс]. - Режим доступа: http://www. yararchive.ru/funds/fund166680/

13. Солеников, А. Исполняется 70 лет со дня пуска [Электронный ресурс] / А. Солеников // Газета «Северный край». - 2002. - 06 июля. - Режим доступа: http://www.sevkray.ru/news/2/29005/).

14. Глухов, В. Туманные перспективы перспективной отрасли [Электронный ресурс] / В. Глухов // Журнал «Рынок Ценных Бумаг». - 2000. - № 11. - Режим доступа: http://old.rcb.ru/archive/articles.asp?id=1234

15. Рязанов, В. Российская промышленность синтетического каучука: логистика, экспорт и инвестиции [Электронный ресурс] / В. Рязанов // Электронная газета «Пластинфо». - 2013. - Режим доступа: http://plastinfo.ru/information/articles/147/

16. Анализ рынка технического углерода в России в 2007-2011 гг., прогноз на 2012-2016 гг. Отчёт РБК [Электронный ресурс]. - Режим доступа: http://marketing.rbc.ru/ research/562949984655723.shtml research/562949984655723.shtml

17. Государственный архив Ярославской области [Электронный ресурс]. - Режим доступа: http://www. yararchive.ru/funds/fund114052/

18. ОАО «Ярославский технический углерод» исполнилось 50 лет // Электронный портал Rosinvest.com 7 февраля 2013 г. - Режим доступа: http://rosinvest.com/novosti/1017795 


\section{References}

1. Grant R.M. Modern Strategic Analysis. 5th edition. Translated from English under the editorship of V.N. Funtov. Saint Petersburg: Piter, 2008. 560 p.

2. Gurova T., Ivanter A. Eti dvoe i ekonomicheskiy rost [These Two and Economic Growth]. Ekspert [Expert], 2013, no. 26 (857), pp. 14-18.

3. Lambin J.J. Menedzhment, orientirovannyy na rynok [Market-Driven Management]. Saint Petersburg: Piter, 2007. $800 \mathrm{p}$.

4. Lebedev O.T. Ekonomika otraslevykh rynkov: uchebnoe posobie [Economics of Branch-Wise Markets: Textbook]. Moscow: Boslen, 2008. 528 p.

5. Mankiw N.G. Macroeconomics. Translated from English. Moscow: Izd-vo MGU, 1994. 736 p.

6. Nelson R. R., Winter S.G. An evolutionary theory of economic change. Moscow: Delo, 2002. 536 p.

7. Strategicheskiy menedzhment [Strategic Management]. Ed. by A.N. Petrov. Saint Petersburg: Piter, 2005. 496 p.

8. Porter M. Competitive strategy. 4th edition. Moscow: Al'pina Pablisher, 2011. 453 p.

9. Rozanova N.M. Ekonomika otraslevykh rynkov: uchebnoe posobie [Economics of Branch-Wise Markets: Textbook]. Moscow: Izdatel'stvo Yurayt, 2010. 906 p.

10. Ryazantsev N.P., Salova Yu.G. Istoriya Yaroslavskogo kraya (1930-2005gg.): uchebnoe posobie dlya uchashchikhsya srednikh obshcheobrazovatel'nykh uchebnykh zavedeniy [The History of the Yaroslavl Region (1930-2005): Textbook for Secondary School Students].Yaroslavl, Rybinsk: B/i, Rybinskiy Dom pechati, 2005. 277 p.

11. Pakhomova N.V., Richter K.K. Ekonomika otraslevykh rynkov i politika gosudarstva: uchebnik [Economics of Branch-Wise Markets and Government Policy: Textbook]. Moscow: ZAO "Izdatel'stvo "Ekonomika", 2009. $815 \mathrm{p}$.

12. Gosudarstvennyy arkhiv Yaroslavskoy oblasti [The State Archive of the Yaroslavl Oblast]. Available at: http://www. yararchive.ru/funds/fund166680/

13. Solenikov A. Ispolnyaetsya 70 let so dnya puska [The 70th Anniversary of the Launch]. Gazeta "Severnyy kray" [Northern Area Newspaper], 2002, July 6. Available at: http://www.sevkray.ru/news/2/29005/

14. Glukhov V. Tumannye perspektivy perspektivnoy otrasli [Vague Prospects of a Promising Industry]. Zhurnal "Rynok tsennykh bumag” [Journal "Securities Market”], 2000, no.11. Available at: http://old.rcb.ru/archive/ articles.asp?id=1234

15. Ryazanov V. Rossiyskaya promyshlennost' sinteticheskogo kauchuka: logistika, eksport i investitsii [Russian Synthetic Rubber Industry: Logistics, Export and Investment]. Elektronnaya gazeta "Plastinfo" [Online Newspaper "Plastinfo"], 2013. Available at: http://plastinfo.ru/information/articles/147/

16. Analiz rynka tekhnicheskogo ugleroda v Rossii v 2007-2011 gg., prognoz na 2012-2016 gg. Otchet RBK [Analysis of the Market of Carbon Black in Russia in 2007-2011, Forecast for 2012-2016. RBC Report]. Available at: http://marketing.rbc.ru/research/562949984655723.shtml

17. Gosudarstvennyy arkhiv Yaroslavskoy oblasti [The State Archive of the Yaroslavl Oblast]. Available at: http://www. yararchive.ru/funds/fund114052/

18. OAO "Yaroslavskiy tekhnicheskiy uglerod" ispolnilos' 50 let [The 50th Anniversary of JSC Yaroslavl Carbon Black]. Internet portal Rosinvest.com, February 7, 2013. Available at: http://rosinvest.com/novosti/1017795 


\section{Возможности и перспективы появления новых нефтеперерабатывающих предприятий в северных регионах России}

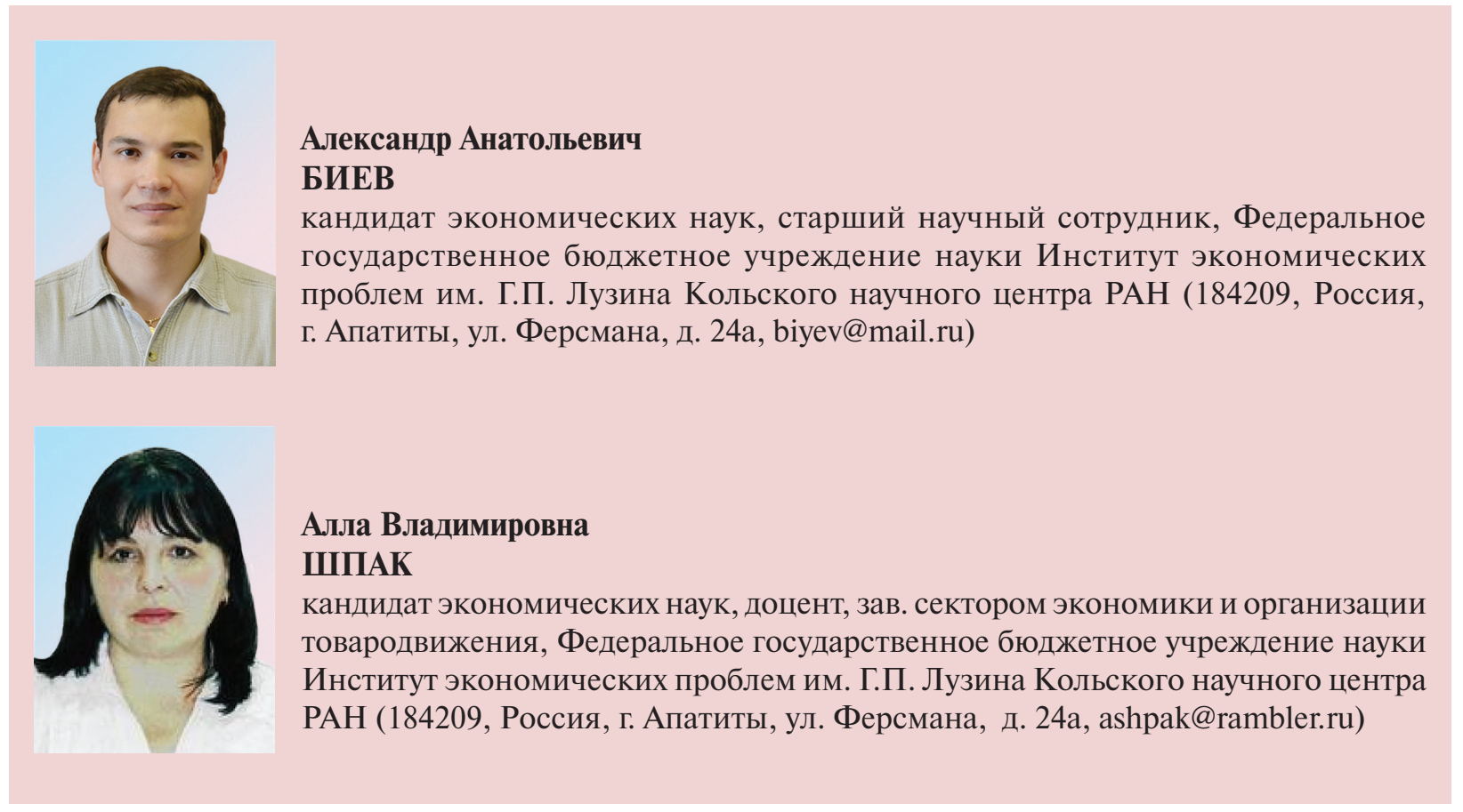

Аннотация. Статья посвящена изучению проблемы совершенствования системы регионального нефтепродуктообеспечения северных территорий России. Рассмотрены ключевые вопросы формирования новой для Мурманской области отрасли региональной экономики - нефтеперерабатывающей. Информационную базу исследования составили аналитические и статистические материалы региональных органов власти северных субъектов РФ и данные, представленные электронными средствами массовой информации. Работа адресована экономистам, специалистам органов регионального и местного управления, представителям предприятий нефтяной промышленности, а также всем тем, кто интересуется топливно-энергетической проблематикой развития Севера нашей страны.

Ключевые слова: Россия, северные регионы, Мурманская область, нефтепереработка. 
Biyev A.A., Shpak A.V.

\section{Opportunities and prospects for the emergence of new refineries in Russia's Northern regions}

Biev Aleksandr Anatol'evich - Ph.D. in Economics, Senior Research Associate, Federal State-Financed Scientific Institution G.P. Luzin Institute of Economic Problems of Kola Scientific Centre of the Russian Academy of Sciences (24A, Fersman Street, Apatity, Murmansk Oblast, 184209, Russia, biyev@mail.ru).

Shpak Alla Vladimirovna - Ph.D. in Economics, Associate Professor, Head of the Department for Economics and Organization of Product Distribution, Federal State-Financed Scientific Institution G.P. Luzin Institute of Economic Problems of Kola Scientific Centre of the Russian Academy of Sciences (24A, Fersman Street, Apatity, Murmansk Oblast, 184209, Russia, ashpak@rambler.ru).

Abstract. The article is devoted to the study of the issue concerning the improvement of the system of regional oil products supply of Russia's Northern territories. It considers the key issues of the formation of oil industry, the regional economic branch that is new for the Murmansk Oblast. The research information base consists of analytical and statistical materials of the regional authorities of Russian Northern subjects and of data presented in the electronic media. The paper is addressed to economists, specialists of regional and local authorities, representatives of oil enterprises, and to all those interested in the range of problems of fuel-and-energy development of our country's North.

Key words: Russia, Northern regions, Murmansk Oblast, oil processing.

Северные территории России традиционно являются крупными центрами не только добычи природных ресурсов, но и их потребления. Самые высокие потребности наблюдаются в отношении топливноэнергетических ресурсов - природного газа, угольного топлива, нефтепродуктов.

И если программам переориентации территориальных энергетических комплексов на использование более дешевых относительно нефти источников энергии, газификации и повышения энергоэффективности регионов, как северных, так и несеверных, в нашей стране уделяется достаточно пристальное внимание, то в отношении диверсификации поставок нефтепродуктов, расширения локального их производства в зоне Севера таких значительных результатов пока нет. Поэтому постоянной угрозой энергобезопасности северных территорий РФ остается острая нехватка нефтеперерабатывающих производств.
Целью данной статьи является определение некоторых перспектив и предпосылок появления новых производственных объектов в пределах зоны Севера Российской Федерации.

Для этого достаточно детально рассматриваются действия, предпринимаемые региональными органами власти во взаимодействии с нефтяными компаниями для разрешения проблем нефтепродуктообеспечения северных регионов РФ. Основное внимание в данной работе уделяется вопросу развертывания производства нефтепродуктов на территории Мурманской области как базового региона, обслуживающего основные грузопотоки по Северному морскому пути.

В своем докладе на заседании президиума Госсовета 28 апреля 2004 г. Президент России В.В. Путин особо отметил необходимость модернизации и обновления энергетического хозяйства северных территорий как одного из основных направлений 
государственной политики в сферах экономического и социального развития районов российского Севера и Дальнего Востока [3]. Проблемы топливного обеспечения отдельных субъектов РФ за последнее десятилетие неоднократно обсуждались не только на самом высоком государственном уровне, но и в общественно-научных кругах. В их обсуждении участвовали признанные отечественные эксперты в этой области.

Так, например, в одной из наиболее известных монографических работ «Экономика и энергетика регионов Российской Федерации» (2001) выделена постановка проблемы топливно-энергетического обеспечения тех регионов, которые снабжаются привозным (особенно дальнепривозным) топливом [10].

За последние 20 лет в России было построено и введено в эксплуатацию только два достаточно крупных объекта нефтепереработки - Нижнекамский и Антипинский нефтеперерабатывающие заводы (НПЗ). Из 30 крупных отечественных НПЗ непосредственно в Арктической зоне России с выходом на трассу Северного морского пути нет ни одного подобного предприятия.

Ближайшими источниками поставок нефтепродуктов для северных субъектов РФ являются нижеследующие: ООО «ПО «КИНЕФ» (Ленинградская область), ОАО «Лукойл-Ухтанефтепереработка» (Республика Коми), Антипинский НПЗ (ХантыМансийский автономный округ - ХМАО), Сургутский завод по стабилизации конденсата (ЗСК), Пуровский завод по переработке конденсата (Ямало-Ненецкий автономный округ).

Поэтому идея создания в Заполярье территориального предприятия нефтепереработки, способного покрыть внутренние потребности региона в нефтепродуктах, поставлять свою продукцию в другие северные регионы по программе «северного завоза» с использованием трассы Северного морского пути и одновременно участвовать в экспортных поставках, появилась сравнительно давно. Примерами развития таких проектов являются планы создания крупных объектов нефтепереработки в Мурманской области, Республике Саха (Якутия), Сахалинской области.

Разработка проекта создания Мурманского НПЗ изначально была связана с инициативой создания Мурманской трубопроводной системы (ОАО «Лукойл», ОАО «Юкос» и др.). В 2000 г. наиболее интенсивно проект нефтеперерабатывающего предприятия разрабатывался компанией «Лукойл». Соглашение о сотрудничестве между ней и руководством Мурманской области было подписано 16 февраля 1999 г. В нем оговаривались совместные действия по обеспечению поставок нефтепродуктов в северные регионы России через нефтебазы Мурманской области [15].

Высокую заинтересованность в появлении такого производственного объекта проявляли не только областное правительство и бывший губернатор Мурманской области Юрий Евдокимов, но и Президент РФ Владимир Путин. В ходе ознакомительного визита в регион он заявил, что поможет «решить вопрос передачи Минобороны Лукойлу нефтебазы Северного Флота» [7]. Местом расположения будущего завода должна была стать нефтебаза «Мохнаткина Пахта» в районе одноименного мыса, рядом с г. Североморск, имеющая для этого всю необходимую инфраструктуру. В качестве альтернативного места расположения рассматривалось побережье Печенгского залива (район Девкиной заводи и Трифонова ручья) [11]. Территория производственной площадки по плану постройки превышала площадь в 100 га (10 кв. км). 
Помимо самого завода, проект «Лукойла» также предусматривал возведение нефтяного перевалочно-транспортного комплекса. Первоначальные расчеты и подготовку материалов по проекту вел институт «Нефтехимпроект» (г. Ростовна-Дону). Планировалось, что производственная мощность завода составит до 3 млн. тонн нефти в год, а стоимость его возведения в ценах того периода не превысит 200 млн. долл. США.

В качестве мер поддержки проекта со стороны региональной администрации (совместно с мэрией г. Мурманска) предусматривалась выдача разрешения на предоставление в долгосрочную аренду городских земельных участков под строительство нескольких (от 3 до 5) автозаправочных комплексов ООО «Лукойл-Северо-Западнефтепродукт». Со своей стороны нефтяная компания гарантировала поставки нефтепродуктов для обеспечения нужд г. Мурманска. Однако, несмотря на подписание всех предварительных соглашений о реализации проекта, а также его поддержку на федеральном уровне, договориться с Министерством обороны РФ о выделении необходимой под завод территории так и не удалось [2].

В 2005 году идея о возведении на Кольском полуострове крупного нефтеперерабатывающего предприятия вновь стала активно обсуждаться в администрации региона, общественно-политических и деловых кругах. О необходимости такого строительства было заявлено заместителем Полномочного представителя президента России в Северо-Западном федеральном округе Любовью Совершаевой на прошедшем в Санкт-Петербурге 4 апреля 2005 г. V Международном форуме «ТЭК России: региональные аспекты». По ее словам, «...нефтяным компаниям этот проект неинтересен с точки зрения экономики, однако, при решении вопросов энергети- ческой безопасности страны и регионов, следует руководствоваться государственными интересами» [21]. Экономическая целесообразность возведения НПЗ с государственной точки зрения заключается в том, что данное предприятие «...позволит обеспечить нефтепродуктами Мурманскую и Архангельскую области, разгрузить Октябрьскую и Северную железные дороги» [там же].

Итогом активного обсуждения перспективных возможностей развертывания локального производства в регионе стала инициативная разработка достаточно крупного (мощностью до 6 млн. тонн нефти в год) НПЗ группой компаний (ГК) «Синтез» (ЗАО «Синтез Петролеум»). Основным назначением будущего предприятия должно было стать производство и транспортировка нефтепродукции в страны Северной Европы (прямогонный бензин и мазут), а также частичное покрытие местных региональных потребностей в светлых нефтепродуктах. Благоприятная ценовая конъюнктура нефтяных рынков стала причиной попытки диверсификации «Синтезом» собственной нефтедобычи и создания бизнес-структуры с завершенным производственным циклом, включая добычу, переработку и сбытовые сети.

В качестве основного источника сырья для НПЗ предполагалась группа шельфовых месторождений (Медынско-Варадейский, Колоколморский, Адмиралтейский и Пахтусовский шельфовые участки), разрабатываемых входящими в группу «Синтез» компаниями $3 \mathrm{AO}$ «Арктикшельфнефтегаз» и «Синтезнефтегаз».

Несмотря на достаточно большие балансовые запасы (на 2007 г. - свыше 400 млн. т нефти), компании, входящие в ЗАО «Корпорация Синтез», были вынуждены отправлять добытую нефть на переработку в Республику Башкортостан, используя т.н. «давальческую» схему. 
Собственного НПЗ у «Синтеза» нет, и создание перерабатывающего актива позволило бы обеспечивать нефтепродуктами сеть автозаправочных комплексов, функционирующую в г. Москве, повысив независимость от других участников отечественного нефтяного рынка. Кроме того, компании группы были заинтересованы в совместном с другими крупными компаниями (прежде всего, ОАО «Роснефть») строительстве экспортного терминала в районе Кольского залива с целью экспортной перевалки до 25 млн. т нефти [16]. Тем же образом, совместно с другими компаниями, реализующими сырую нефть на экспорт через Мурманский морской торговый порт, планировалось загрузить сырьем будущий НПЗ. Для реализации этих планов ГК «Синтез» была готова инвестировать от 400 до 550 млн. долл. США (в зависимости от конфигурации терминала) [1]. Несмотря на обещание столь значительных средств, а также всяческую поддержку со стороны федеральных и местных органов власти (премьер-министра М. Фрадкова и вице-губернатора Мурманской области А. Рузанкина), практическое исполнение этих масштабных замыслов было значительно осложнено. Выбранная под строительство НПЗ площадка на западном берегу Кольского залива (район устья реки Лавна) не имела связи с электрическими и транспортными сетями региона [9]. В итоге изменившаяся экономическая ситуация привела к остановке осуществления проекта на самой ранней стадии.

В то же время намерения о строительстве нефтеперерабатывающего предприятия малой производственной мощности (до 100 тыс. т углеводородного сырья в год) высказывала компания «Гамма Север», занимающаяся оптовой продажей нефтепродуктов и их транспортировкой на территории Мурманской области. Местом строительства предприятия разработчик называл район железнодорожной станции Тайбола (Мурманское отделение Октябрьской железной дороги, Кольский район). Основным сырьем, используемым предприятием при производстве товарной продукции, должен был стать стабильный газовый конденсат и фракционный нефтяной конденсат, получаемый при добыче нефти как попутный продукт. Оценка необходимого объема инвестиционных вложений варьировалась в диапазоне 120-150 млн. руб.

Небольшая производительность миниНПЗ не позволяла рассчитывать на расширение географии поставок за пределы муниципальных образований Кольского района и областного центра. В июне 2007 года в Правительстве Мурманской области состоялось заседание межведомственной комиссии по размещению производительных сил, на котором рассматривался проект по строительству мини-НПЗ ООО «Гамма Север». Члены комиссии подвергли критике экономическое обоснование и экологические аспекты реализации проекта.

В части экономических сложностей развертывания производства на выбранной площадке железнодорожной станции Тайбола было заявлено, что в настоящий момент она не функционирует, а расчет предполагаемых затрат на ее введение в строй, издержек разработчика на эксплуатацию и содержание станции, а также другие показатели проекта в комиссию для обсуждения внесены не были. Представитель Октябрьской железной дороги высказал предположение, что, скорее всего, доставка готовой продукции вместо ст. Тайбола будет осуществляться к ближайшей станции Кола, что неблагоприятно повлияет на процесс ценообразования [4]. В случае же принятия первоначального решения о восстановлении станции Тайбола увеличение расходов может вообще сделать проект убыточным. 
Члены комиссии поставили под сомнение и вопросы экологической безопасности завода. По словам заместителя областного комитета по природным ресурсам Алексея Смирнова, проектант не может гарантировать, что акватория реки Колы будет защищена от загрязнения. «Последствия же могут быть самыми критичными», отметил Смирнов [там же]. В дальнейшем обсуждении доводы заместителя директора компании «Гамма Север» В. Лисина о наличии двух альтернативных площадок для строительства комплекса остались без внимания. Заместителем председателя комиссии Александром Макаровым было озвучено замечание о непредставлении самой проектной документации, что и стало одной из основных причин отказа комиссии в дальнейшем рассмотрении возможности строительства ООО «Гамма Север» данного модульного НПЗ.

Очередной всплеск обсуждений на тему мурманского НПЗ и наибольшую поддержку региональных властей получили планы $3 \mathrm{AO}$ «Севморнефтегаз» (OOO «Газпромнефтьшельф», ОАО «Газпром»), которые были озвучены компанией в 2010 году. Появление этого проекта было напрямую связано с ожидавшейся интенсификацией процессов освоения углеводородного сырья на арктическом шельфе. На этот раз речь снова зашла о создании мегазавода, способного кардинально решить топливную проблему северного региона. Тем не менее инициатор сразу пояснил, что, хотя основным предназначением этого объекта будет экспортное производство, большая часть нефтепродуктов может перенаправляться для нужд внутреннего рынка. Рассматривались несколько вариантов производительности НПЗ. По словам генерального директора «Севморнефтегаза» Александра Манделя, мощность предприятия должна была составить 5-10 млн. т [20].
В зависимости от выбранного объема выработки продукции НПЗ, инвестиции ОАО «Газпром» могли достигнуть 7 млрд. долл. США [19]. Предполагалось, что основной сырьевой базой проекта будут поставки нефти от Приразломного, Долгинского, Варандейского и Медынского месторождений (Печорское море), а также, возможно, от Ростовцевского и Новопортовского месторождений Ямала. Основные этапы подготовки и реализации столь грандиозных планов предусматривали окончание выработки технико-экономического обоснования инвестиций в проект к концу 2010 года. После принятия принципиального решения о возведении объекта на этап его строительства отводилось до 5 лет. Введение в строй НПЗ (в 2016 г.) должно было совпасть с достижением пиковой добычи нефти на Приразломном месторождении. К этому сроку, согласно имевшимся тогда планам, должна была быть начата добыча первой нефти Долгинского месторождения. Местом расположения НПЗ указывалась производственная площадка близ поселка Междуречье.

Планы строительства НПЗ тесно пересекались с другим проектом ОАО «Газпром» в поселке Териберка, на территории которого ранее было запланировано возведение завода по сжижению газа ОАО «Газпром» с использованием сырьевой базы Штокмановского газоконденсатного месторождения. Поэтому, помимо планов переработки нефти, НПЗ мог быть использован для переработки газового конденсата со Штокмановского месторождения в объеме до 600 тыс. т в год. Согласно планам «Газпрома» на собственные нужды концерна в регионе должно было пойти около 1,5 млн. тонн произведенных нефтепродуктов, на нужды Мурманской и Архангельской области - суммарно до 4 млн. т. Таким образом, общий объем поставок за пределы региона и на экспорт не превысил бы 4,5 млн. тонн. 
В 2011 году проект возведения «газпромовского» НПЗ на Кольском полуострове был скорректирован, однако принципиального решения о начале строительства принято так и не было. Местом потенциального размешения объекта теперь стали называть площадку на западном берегу Кольского залива «...вблизи проектируемого к строительству нового района Мурманского морского торгового порта» [18].

Изначально в процессе отбора наиболее подходящего района расположения НПЗ рассматривалось 12 возможных вариантов. В качестве ведущей проектной организации упоминалось ООО «ГазпромВНИИГАЗ» [12]. Расширялась товарная номенклатура производства НПЗ. Теперь, помимо нефтепродуктов, она включала в себя продукцию более высокого передела товары нефтехимии. Основной продукцией завода должно было стать дизельное топливо, автомобильные бензины (марки Аи-92/95), судовое топливо, авиационный керосин и материалы нефтехимии. Предварительные характеристики будущего предприятия и предстоящего строительства озвучил побывавший в Мурманской области в начале ноября 2011 г. заместитель председателя Государственной Думы РФ президент Российского газового общества Валерий Язев. Требуемые капитальные вложения, по скорректированным оценкам, возросли и составили около 250 млрд. рублей. Согласно новому проекту, планировалось создать более 1800 рабочих мест. Планируемая производственная мощность должна была вырасти до 16 млн. тонн в год.

Предполагалось, что производственная территория НПЗ займет от 12 до 18 кв. км площади. Вместе с заводом планировалось строительство «с нуля» всей комплексной инфраструктуры: железнодорожной ветки, причальных сооружений, портофлота, накопительной базы готовой продукции, сырьевых трубопроводов терминала, продуктопроводов и пр.

В конце июля 2011 года между членами Правительства Мурманской области (главой комитета по промышленному развитию, экологии и природопользованию Олегом Крапивиным, министром экономического развития Сергеем Агарковым) и представителями ОАО «Газпром» состоялась встреча, в ходе которой последними была подана для рассмотрения Декларация о намерениях по выбору площадки под строительство будущего предприятия.

В ней оговаривался 9-летний срок реализации этапа строительства НПЗ - 20112020 гг. [17]. Общий срок эксплуатации объекта -25 лет. К концу года компанией было решено, что непосредственно строительство, в случае положительного исхода предварительных общественных слушаний и согласований, должно будет начаться не ранее 2016 г. В декабре 2011 года на общественных слушаниях в рамках обоснования инвестиций в строительство НПЗ, проходивших в г. Полярный (ЗАТО Александровск) и поселке Междуречье (Кольский район Мурманской области), были оглашены некоторые дополнительные характеристики предприятия, касающиеся экологических и экономических аспектов его деятельности.

По словам начальника управления промышленной и экологической безопасности ЗАО «Научно-производственная фирма «Диэм» (разработчик оценки воздействия на окружающую среду проекта) Александра Федоренко, «...во время работы комплекса будут образовываться 29 видов отходов общим количеством более 23000 тонн в год. Самую большую их часть $(95,6 \%)$ будут представлять отходы третьего класса опасности - так называемые нефтешламы. До 97\% нефтешламов будет перерабатываться 
на самом предприятии и подлежать захоронению на полигоне твердых бытовых отходов. Пока место расположения полигона не определено: оно может находиться на территории самого комплекса НПЗ или для этих целей могут привлекаться сторонние организации» [8]. Общее количество новых рабочих мест, которые должно было предоставить создаваемое предприятие для экономики региона, возросло с 1816 до 4025 [13].

Объем налоговых отчислений в областной бюджет за все время работы завода должен был составить 278 млрд. рублей. Оценка относительно количества специалистов и рабочих, необходимых для ведения строительно-монтажных работ на территории поселка, достигла 8000 человек (количество жителей самого п. Междуречье - 975 человек). Для энергоснабжения завода в Кольском районе к 2020 г. требовалось дополнительно создание около 200 МВт электрической мощности. Несмотря на то, что первые общественные слушания прошли достаточно успешно и экологические аспекты деятельности будущего НПЗ не вызывали резкой критики присутствовавших на них специалистов, в дальнейшем именно экологическая опасность проекта стала основной причиной его приостановки.

В сентябре 2012 г. Федеральная служба по надзору в сфере природопользования (Росприроднадзор) завершила госэкоэкспертизу документации «Обоснование инвестиций строительства нефтеперерабатывающего завода в районе Мурманска». Экспертная комиссия установила несоответствие представленной документации требованиям законодательства в области охраны окружающей среды. Заключение экспертной комиссии госэкоэкспертизы было утверждено приказом Росприроднадзора от 28.09.2012 №524 [5].
Таким образом, несмотря на повышенное внимание общественности и организацию «зеленого коридора» для планов $\mathrm{OAO}$ «Газпром» региональной администрацией, проект мурманского НПЗ был снова «заморожен» на этапе предварительных согласований с федеральными надзорными органами.

До середины 2012 г. уже достаточно туманные перспективы создания в регионе крупного НПЗ связывали с ОАО «Лукойл», которое еще в мае 2000 г. планировало приступить к реализации проекта строительства предприятия производственной мощностью 3 млн. т нефтепродуктов в год. В июле 2012 г. губернатор Мурманской области Мария Ковтун провела рабочую встречу с генеральным директором ООО «ЛукойлСеверо-Западнефтепродукт» Максимом Хитровым и генеральным директором ООО «Лукойл-Резервнефтепродукт» Владимиром Юхневым, на которой вновь поднимался вопрос о перспективах строительства на территории региона нефтеперерабатывающего завода ОАО «Лукойл». По словам новой главы региона, «...это позволит снизить транспортную составляющую в структуре цены на топливо и окажет макроэкономический эффект на социальную и производственную сферу жизни региона» [14].

В качестве мер поддержки деятельности компании в регионе администрацией Мурманской области, как и в 2000 году, оговаривалась возможность строительства 5 автозаправочных комплексов ООО «Лукойл-Северо-Западнефтепродукт». Однако, учитывая не совсем удачный собственный опыт реализации подобных планов в Мурманской области, компания «Лукойл» очень осторожно подошла к разработке новых масштабных проектов. В настоящее время «реанимация» проекта НП3 «Лукойл» в Мурманской области, предложенная М. Ковтун, в очередной раз отложена на неопределенный срок. 
Существуют и другие проекты перерабатывающих предприятий, способных стать базообразующими для системы «северного завоза». В числе прочих выделяются инициативы правительств Сахалинской области и Республики Саха (Якутия).

Проект сахалинского НПЗ прорабатывается уже более 5 лет, но окончательного технико-экономического и инвестиционного решения по нему также не было принято. Мощность предприятия должна была составить от 4 до 10 млн. т в год, что было бы достаточно для покрытия потребности, помимо самой Сахалинской области, Камчатского края, Чукотки, Магаданской области. Излишек производимой продукции планировалось поставлять на экспорт в страны Юго-Азиатского региона.

Основным проектантом и собственником нового предприятия должно было выступить ОАО «Газпром». На раннем этапе проработки другой потенциальный участник - ОАО «НК Роснефть» сразу отказалось от дальнейшего участия, сославшись на недостаточный уровень внутреннего регионального спроса и общую низкую экономическую эффективность проекта [6]. В настоящее время на Сахалине из нефтеперерабатывающих мощностей действует только модульный мини-завод компании «Петросах» в Победино мощностью 200 тыс. т, но пока переработка нефти на нем составляет порядка 36 тыс.т и в дальнейшем будет снижаться.

Правительством Республики Саха, для покрытия части внутренних потребностей, а также участия в снабжении приграничных с республикой территорий, инициированы планы возведения завода по производству синтетических моторных топлив на базе переработки газа. Ожидаемое появление такого предприятия в районе г. Алдан позволило бы обеспечивать светлыми нефтепродуктами южный и центральный районы Республики Саха (Якутия).
Ранее, в 2007 г., компания «Алроса», после предварительных расчетов и начальной оценки экономической эффективности предприятия, отказалась от строительства НПЗ на территории Республики Саха. Производительность завода должна была превысить 250 тыс. т нефтепродуктов в год. Основная причина принятия инвестором решения о выходе из проекта по строительству НПЗ та же, что и в Сахалинской области, - недостаточная привлекательность местного рынка, сложные условия хозяйствования и, как следствие всего вышеперечисленного, низкая общая эффективность реализации, по сути, социального проекта. Тем не менее в феврале 2010 г. в рамках формирования Комплексного плана развития Южной Якутии рассматривалось сразу несколько вариантов строительства новых энергетических объектов. Предполагалось дополнительно построить новый газохимический завод, который также должен был располагаться в Алдане либо в Ленске. Исполнителем проекта выступало $\mathrm{OAO}$ «Газпром».

Кроме проектов строительства достаточно крупных, «опорных» для программы «северного завоза» нефтеперерабатывающих предприятий, активно разрабатываются планы развертывания малых модульных НПЗ для удовлетворения локальных нужд потребителей, удаленных от систем централизованных поставок нефтепродуктов. И достаточно удачный опыт внедрения подобного рода проектов в условиях хозяйствования северных территорий уже имеется.

Например, в соответствии с программой реконструкции и модернизации жилищно-коммунального хозяйства Эвенкии (северный район Красноярского края) предусмотрено строительство мини-НПЗ в Байките и Ванаваре. В 2009 году был запущен НПЗ малой производительности 
на Ванкоре - по выработке дизтоплива для внутреннего потребления. Это позволило избавиться от потребности в завозе нефтепродуктов для собственных нужд местных поселений. В ХМАО функционирует более 20 установок нефтепереработки на промысловых участках. В Якутии также осуществлялось развертывание сети малых НП3. Три компании (OAO «Саханефтегаз», ЗАО «Иреляхнефть» и ООО «Таас Юрях-нефтегазодобыча») возводили малогабаритные комплексы нефтепереработки для покрытия собственных топливных нужд, но все они по тем или иным причинам были вынуждены прекратить строительство в 2002 г. Один из проектов (Витимский малогабаритный нефтеперерабатывающий комплекс мощностью 50 тыс. тонн продукции в год, заказчик ОАО «Саханефтегаз») на 01.01.2012 г. имел строительную готовность $98 \%$.
Если проводить сравнение между северными регионами, традиционно относимыми к проблемным с точки зрения их обеспечения нефтепродуктами, таким как Республика Саха (Якутия), Мурманская и Сахалинская области, то, например, с позиции потенциальной экономии транспортных издержек региональных потребителей востребованность нефтеперерабатывающего предприятия в Мурманской области выглядит предпочтительнее.

В таблице показаны результаты расчетов по определению предполагаемого эффекта для региональной экономики (потребителей нефтепродуктов) от появления на территории субъекта Федерации нефтеперерабатывающего предприятия, полностью или частично покрывающего потребности региона в основных видах энергоресурсов.

Определение экономического эффректа от появления локальных нестеперерабатывающих предприятий и снижения транспортных затрат на завоз нефтепродуктов в Мурманской и Сахалинской области, Республике Саха

\begin{tabular}{|c|c|c|c|c|}
\hline Регион & $\begin{array}{c}\text { Объем } \\
\text { потребления } \\
\text { несртепродуктов } \\
\text { в регионе, } \\
\text { тыс. т/год }\end{array}$ & $\begin{array}{c}\text { Общие транспортные издержки } \\
\text { на доставку нефртепродуктов } \\
\text { в регион (магистральные виды } \\
\text { транспорта, без учета стоимости } \\
\text { перевалки), тыс. руб./год }\end{array}$ & $\begin{array}{c}\text { Средняя стоимость } \\
\text { доставки } \\
\text { нефтепродуктов } \\
\text { по территории региона, } \\
\text { тыс. руб./год }\end{array}$ & $\begin{array}{c}\text { Предполагаемый } \\
\text { эфффект от снижения } \\
\text { транспортных затрат } \\
\text { на завоз нефтепродуктов } \\
\text { в регион, тыс. руб./год }\end{array}$ \\
\hline $\begin{array}{l}\text { Мурманская } \\
\text { область* }\end{array}$ & $\begin{array}{c}\text { АБ } 300 \\
\text { ДТ } 500 \\
\text { ТМ } 1800\end{array}$ & $\begin{array}{c}600537 \\
1052500 \\
3388338\end{array}$ & $\begin{array}{c}232317 \\
404455 \\
1284876\end{array}$ & $\begin{array}{c}368220 \\
648045 \\
2103462\end{array}$ \\
\hline $\begin{array}{l}\text { Сахалинская } \\
\text { область ** }\end{array}$ & $\begin{array}{l}\text { АБ 24,2 } \\
\text { ДТ } 37,2\end{array}$ & $\begin{array}{c}69304 \\
105053\end{array}$ & $\begin{array}{l}35090 \\
66001\end{array}$ & $\begin{array}{l}34214 \\
39052\end{array}$ \\
\hline $\begin{array}{l}\text { Республика } \\
\text { Саха } \\
\text { (Якутия) }^{* \star *}\end{array}$ & $\begin{array}{c}\text { АБ } 258 \\
\text { ДТ } 528 \\
\text { ТМ 10,5 }\end{array}$ & $\begin{array}{c}969945 \\
2037552 \\
37254\end{array}$ & $\begin{array}{c}830631 \\
1722864 \\
13482\end{array}$ & $\begin{array}{c}139314 \\
314688 \\
23772\end{array}$ \\
\hline Всего & - & 8260483 & 4589716 & 3670767 \\
\hline \multicolumn{5}{|c|}{ 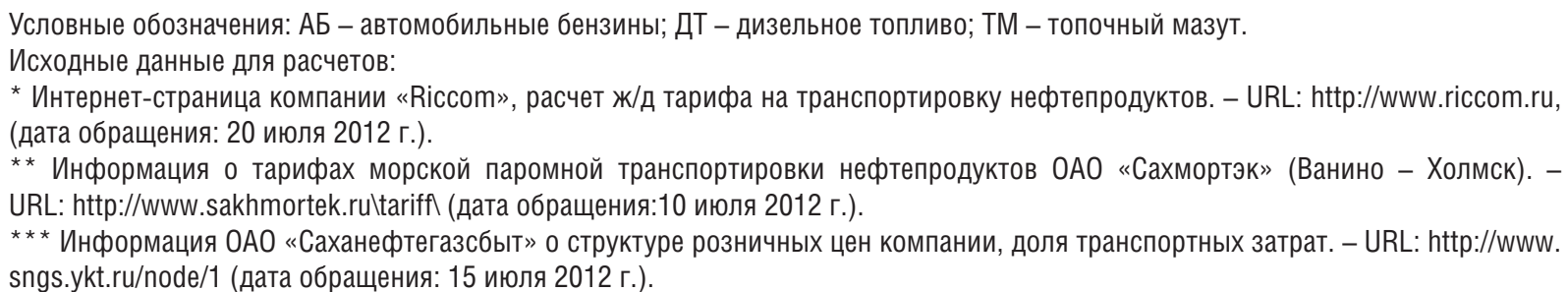 } \\
\hline
\end{tabular}


Общий эффект для региональной экономики от снижения затрат на транспортировку нефтепродуктов из других регионов рассчитан как разница между стоимостью завоза нефтепродуктов извне до региональных нефтебаз и стоимостью транспортировки в границах территории региона от месторасположения локального НПЗ.

Полученные оценки указывают на то, что совокупный годовой эффект при реализации планов строительства НПЗ на территории всех трех субъектов Федерации может превысить 3,5 млрд. руб. Самая высокая оценка ожидаемого эффекта от развертывания локального производства в Мурманской области - около 3,1 млрд. руб. в год - связывается с решением таким образом проблемы поставок мазутного топлива. Самая низкая оценка - в Сахалинской области - обусловлена недостаточной полнотой учета официальной статистикой масштабов регионального потребления, что привело в итоговых расчетах к значительному сокращению показателя последней графы. Всего же общие издержки от регулярного завоза энергоресурсов, относимых на использование магистральных видов транспорта, для трех рассматриваемых субъектов Федерации оцениваются свыше 8,26 млрд. руб. Из них затраты на снабжение потребителей Мурманской области составляют около 5 млрд. рублей в год, Сахалинской области - около 200 млн. руб., Республики Саха (Якутия) свыше 3 млрд. рублей.
Представленные результаты показывают, что развертывание регионального производства нефтепродуктов в указанных регионах позволит только за счет сокращения транспортной составляющей снизить издержки в сфере регионального нефтепродуктообеспечения на 44,4\% - до 4,6 миллиарда рублей. Понимая это, региональные органы власти ведут активную работу по поддержке, дальнейшему продвижению инициатив как крупных федеральных, так и местных компаний, занимающихся разработкой и реализацией проектов локального производства энергоресурсов, их рационального использования (энергосбережения).

Таким образом, несмотря на проводимую работу по оптимизации существующих схем материально-технического снабжения как в целом регионов Севера и Дальнего Востока, так и Мурманской области в частности, можно сказать, что основные потребности в моторном топливе и светлых нефтепродуктах продолжают удовлетворяться на основе поставок из нескольких центров нефтегазовой промышленности России. Поэтому наиболее вероятными направлениями дальнейшей модернизации топливно-энергетической сферы северных территорий в ближайшем будущем следует считать расширение сети малых и модульных НПЗ, создаваемых в местах интенсивной эксплуатации месторождений углеводородного сырья, а также расширение возможностей транспортно-энергетической сети на Севере России.

\section{Литература}

1. Беккер, А.С. Порт как зона [Электронный ресурс] / А.С. Беккер // Ведомости. - 2006. - 28 марта. Режим доступа: http://www.portmurmansk.ru/index.phtml?1223

2. Лукойл не пускают в Мохнаткину Пахту [Электронный ресурс] // Коммерсант. - 2000. - №24(1909). 15 февр. - Режим доступа: http://www.kommersant.ru/doc/140146 
3. Доклад Президента РФ В.В. Путина «Об основах государственной политики Российской Федерации в районах Севера» на заседании президиума Госсовета от 28 апреля 2004 г. №36 [Электронный ресурс]. Режим доступа: http://archive.kremlin.ru/text/appears2/2004/04/28/97302.shtml

4. Комиссия по размещению производительных сил нашла много минусов в предложении строительства мини-НПЗ в Мурманской области. 20 июня 2007 года [Электронный ресурс] // ИА «Би-порт». - Режим доступа: http://www.b-port.com/

5. Завершена экологическая экспертиза документации по строительству нефтеперерабатывающего завода в районе Мурманска. 30 октября 2012 г. [Электронный ресурс] // ИА «Би-порт». - Режим доступа: http:// www.b-port.com/news/item/90737.html

6. Власти Сахалинской области пытаются реанимировать идею создания НПЗ. 29 сентября 2011 г. [Электронный ресурс] // ИД «Коммерсант». - Режим доступа: http://www.kommersant.ru/

7. Мурманск рассчитывает на завод. 12 апреля 2000 г. // Интернет портал «Деловой Петербург». - Режим доступа: http://www.dp.ru/Pages/ArticleDetail.aspx/?ArticleID=23369be9-fc41-4ade-92b2-9039d6775b35

8. Киреева, А. Строительство НПЗ входит в практическую плоскость / А. Киреева // Сайт некоммерческой общественной организации «Беллона». 7 декабря 2011 г. - Режим доступа: http://www.bellona.ru/ articles_ru/articles_2011/1323269037.15

9. Колесник, Е. Синтезу нужен НПЗ [Электронный ресурс] / Е. Колесник // Ежедневная деловая газета «RBC Daily». - 2007. - 8 февр. - Режим доступа: http://www.rbcdaily.ru/

10. Экономика и энергетика регионов Российской Федерации / А.М. Мастепанов, В.В. Саенко, В.А. Рыльский, Ю.К. Шафраник. - М.: ЗАО «Изд-во «Экономика», 2001. - 467 с.

11. «Небо в алмазах» над Кольским Севером [Электронный ресурс] // Нефть России: информационноаналитический журнал. - 2001. - №12. - Дек. - Режим доступа: http://www.oilru.com/nr/93/1209/oilru. com

12. В г. Полярный (ЗАТО Александровск) и п. Междуречье прошли общественные слушания по обоснованию инвестиций строительства нефтеперерабатывающего завода (НПЗ) в районе Мурманска. 13 декабря 2011 г. // Официальный портал Правительства Мурманской области. - Режим доступа: http://nature.gov-murman.ru/news/?date_time=13-12-2011_09:23

13. Перспективы развития есть [Электронный ресурс] // Кольское слово: газета Кольского района Мурманской области. - 2011. - 16 дек. - Режим доступа: http://kolskoeslovo.ru/news/2011-12-20/1056/

14. Пресс-релиз Управления информационной политики и взаимодействия со СМИ Аппарата Правительства Мурманской области. 300 млн. рублей «Лукойл» направит на строительство новых АЗС в Мурманской области. 12 июля 2012 г. [Электронный ресурс]. - Режим доступа: http://www.gov-murman.ru/ press $/ ? \mathrm{~d}=13-07-2012 \_12: 04$

15. Пресс-релиз «ОАО «Лукойл развивает сотрудничество с Мурманской областью». 16 марта 1999 г. [Электронный ресурс] / Пресс-служба ОАО «Лукойл». - Режим доступа: http://www.lukoil.ru/press.asp?div_ $\mathrm{id}=1 \& \mathrm{id}=171 \&$ year $=1999$

16. Синтез построит терминал в Мурманске. 1 сентября 2012 г. [Электронный ресурс] // ИA «InfraNews». Режим доступа: http://infranews.ru/logistika/more/8952-sintez-postroit-terminal-v-murmanske/

17. Мурманск в ожидании НП3. 23 августа 2011 г. [Электронный ресурс] // ИА «Nordnews». - Peжим доступа: http://www.nord-news.ru/topic/?mtopicid=295

18. Нефтеперерабатывающий завод в Мурманской области необходим. 1 ноября 2011 г. [Электронный peсурс] // ИА «Nordnews».- Режим доступа: http://www.nord-news.ru/murman_news/2011/11/01/ ?newsid $=21720$

19. «Газпром» вложит в строительство НПЗ в Мурманской области от трех до семи млрд. долларов США. 14 сентября 2011 г. [Электронный ресурс] // ИА «OilCapital». - Режим доступа: http://www.oilcapital.ru/ industry/35427.html

20. «Газпром» планирует до конца 2010 года завершить подготовку обоснования инвестиций проекта НПЗ в Мурманской области. 3 февраля 2010 г. [Электронный ресурс] // ИА «Portnews». - Режим доступа: http://portnews.ru/

21. Северо-Западное полпредство считает нужным строить НПЗ на Кольском полуострове. 4 апреля 2005 г. [Электронный ресурс] // ИА «REGNUM». - Режим доступа: http://www.murmannews.ru/allnews/432288/ 


\section{References}

1. Bekker A.S. Port kak zona [Port as a zone]. Vedomosti [Bulletin], 2006, March 28. Available at: http://www. portmurmansk.ru/index.phtml? 1223

2. Lukoyl ne puskayut v Mokhnatkinu Pakhtu [LUKOIL is kept out of Mokhnatkina Pakhta]. Kommersant [Businessman], 2000, no. 24 (1909), February 15. Available at: http://www.kommersant.ru/doc/140146

3. Doklad Prezidenta RF V.V. Putina "Ob osnovakh gosudarstvennoy politiki Rossiyskoy Federatsii v rayonakh Severa" na zasedanii prezidiuma Gossoveta ot 28 aprelya 2004 g. №36 [The Report of Russian President V.V. Putin "On the Fundamentals of Russia's State Policy in the Regions of the North" at the Session of the Presidium of the State Council on April 28, 2004 No.36]. Available at: http://archive.kremlin.ru/text/ appears2/2004/04/28/97302.shtml

4. Komissiya po razmeshcheniyu proizvoditel'nykh sil nashla mnogo minusov v predlozhenii stroitel'stva miniNPZ v Murmanskoy oblasti. 20 iyunya 2007 goda [Commission on the Distribution of Productive Forces has found a lot of shortcomings in the proposal for the construction of a mini-refinery in the Murmansk Oblast. June 20, 2007]. IA "Bi-port". Available at: http://www.b-port.com

5. Zavershena ekologicheskaya ekspertiza dokumentatsii po stroitel'stvu neftepererabatyvayushchego zavoda $v$ rayone Murmanska. 30 oktyabrya $2012 \mathrm{~g}$. [Environmental expert review of the documentation on the oil refinery construction in the Murmansk area has been completed. October 30, 2012]. IA "Bi-port". Available at: http:// www.b-port.com/news/item/90737.html

6. Vlasti Sakhalinskoy oblasti pytayutsya reanimirovat' ideyu sozdaniya NPZ. 29 sentyabrya 2011 g. [The authorities of the Sakhalin Oblast are trying to revive the idea of creating a refinery. September 29, 2011]. Publishing House "Kommersant". Available at: http://www.kommersant.ru/

7. Murmansk rasschityvaet na zavod. 12 aprelya $2000 \mathrm{~g}$. [Murmansk counts on the plant]. Internet portal "Delovoy Peterburg”. Available at: http://www.dp.ru/Pages/ArticleDetail.aspx?ArticleID=23369be9-fc41-4ade-92b29039d6775b35

8. Kireeva A. Stroitel'stvo NPZ vkhodit v prakticheskuyu ploskost' [Construction of oil refinery is included in practice]. Website of the Non-Profit Public Organization "Bellona". December 7, 2011. Available at: http:// www.bellona.ru/articles_ru/articles_2011/1323269037.15

9. Kolesnik E. Sintezu nuzhen NPZ [SINTEZ needs an oil refinery]."RBC Daily”, 2007, February 8. Available at: http://www.rbcdaily.ru/

10. Mastepanov A.M., Saenko V.V., Ryl'skiy V.A., Shafranik Yu.K. Ekonomika i energetika regionov Rossiyskoy Federatsii [Economy and energy in the regions of the Russian Federation]. Moscow: ZAO "Izd-vo "Ekonomika", $2001.467 \mathrm{p}$.

11. "Nebo v almazakh" nad Kol'skim Severom ["Jewelled sky" over the Kola North]. Neft' Rossii: informatsionnoanaliticheskiy zhurnal [Oil of Russia: Information and Analytical Journal], 2001, no. 12. December. Available at: http://www.oilru.com/nr/93/1209/oilru.com

12. V g. Polyarnyy (ZATO Aleksandrovsk) i p. Mezhdurech'e proshli obshchestvennye slushaniya po obosnovaniyu investitsiy stroitel'stva neftepererabatyvayushchego zavoda (NPZ) v rayone Murmanska. 13 dekabrya $2011 \mathrm{~g}$. [Public hearings for the substantiation of investments in the construction of an oil refinery in the Murmansk Area were held in the town of Polyarnyy (Closed Administrative-Territorial Unit Aleksandrovsk) and the village of Mezhduretchie. December 13, 2011]. Ofitsial'nyy portal Pravitel'stva Murmanskoy oblasti [Official Portal of the Murmansk Oblast Government]. Available at: http://nature.gov-murman.ru/news/?date_time=13-122011_09:23

13. Perspektivy razvitiya est' [Development prospects exist]. Kol'skoe slovo: gazeta Kol'skogo rayona Murmanskoy oblasti [Kolskoye Slovo: Newspaper of the Kola District of the Murmansk Oblast], 2011, December 16. Available at: http://kolskoeslovo.ru/news/2011-12-20/1056/

14. Press-reliz Upravleniya informatsionnoy politiki i vzaimodeystviya so SMI Apparata Pravitel'stva Murmanskoy oblasti. 300 mln. rubley “Lukoyl” napravit na stroitel'stvo novykh AZS v Murmanskoy oblasti. 12 iyulya $2012 \mathrm{~g}$. [Press release of the Administration for Information Policy and Media Relations of the Murmansk Oblast Government Office. LUKOIL will assign 300 million rubles for the construction of new petrol stations in the Murmansk Oblast. July 12, 2012]. Available at: http://www.gov-murman.ru/press/?d=13-07-2012_12:04

15. Press-reliz "OAO "Lukoyl razvivaet sotrudnichestvo s Murmanskoy oblast'yu". 16 marta 1999 g. [Press-release "OAO LUKOIL Promotes Cooperation with the Murmansk Oblast". March 16, 1999]. Press-sluzhba OAO "Lukoyl” [OAO LUKOIL Press Service].Available at:http://www.lukoil.ru/press.asp?div_id=1\&id=171\&year=1999 
16. Sintez postroit terminal v Murmanske. 1 sentyabrya $2012 \mathrm{~g}$. [SINTEZ Is to build a terminal in Murmansk. September 1, 2012]. IA “InfraNews”. Available at: http://infranews.ru/logistika/more/8952-sintez-postroitterminal-v-murmanske/

17. Murmansk v ozhidanii NPZ. 23 avgusta 2011 g. [Murmansk is in expectation of an oil refinery. August 23, 2011]. IA "Nordnews". Available at: http://www.nord-news.ru/topic/?mtopicid=295

18. Neftepererabatyvayushchiy zavod v Murmanskoy oblasti neobkhodim. 1 noyabrya $2011 \mathrm{~g}$. [Oil refinery is needed in the Murmansk Oblast. November 1, 2011]. IA “Nordnews”. Available at: http://www.nord-news.ru/murman news $/ 2011 / 11 / 01 /$ ?newsid $=21720$

19. “Gazprom" vlozhit v stroitel'stvo NPZ v Murmanskoy oblasti ot trekh do semi mlrd. dollarov SShA. 14 sentyabrya $2011 \mathrm{~g}$. [Gazprom will invest from 3 to 7 billion US dollars in the construction of an oil refinery in the Murmansk Oblast. September 14, 2011]. IA “OilCapital”. Available at: http://www.oilcapital.ru/industry/35427.html

20. “Gazprom” planiruet do kontsa 2010 goda zavershit' podgotovku obosnovaniya investitsiy proekta NPZ v Murmanskoy oblasti. 3 fevralya 2010 g. [Gazprom plans to complete the feasibility study of the project of oil refinery in the Murmansk Oblast before the end of 2010. February 3, 2010]. IA "Portnews". Available at: http:// portnews.ru/

21. Severo-Zapadnoe polpredstvo schitaet nuzhnym stroit' NPZ na Kol'skom poluostrove. 4 aprelya 2005 g. [Northwestern plenipotentiary representatives considers it necessary to build an oil refinery in the Kola Peninsula. April 4, 2005]. IA "REGNUM". Available at: http://www.murmannews.ru/allnews/432288/ 


\section{Состояние нормативно-правовой базы и перспективы развития механизма участия общественности в управлении лесами России}

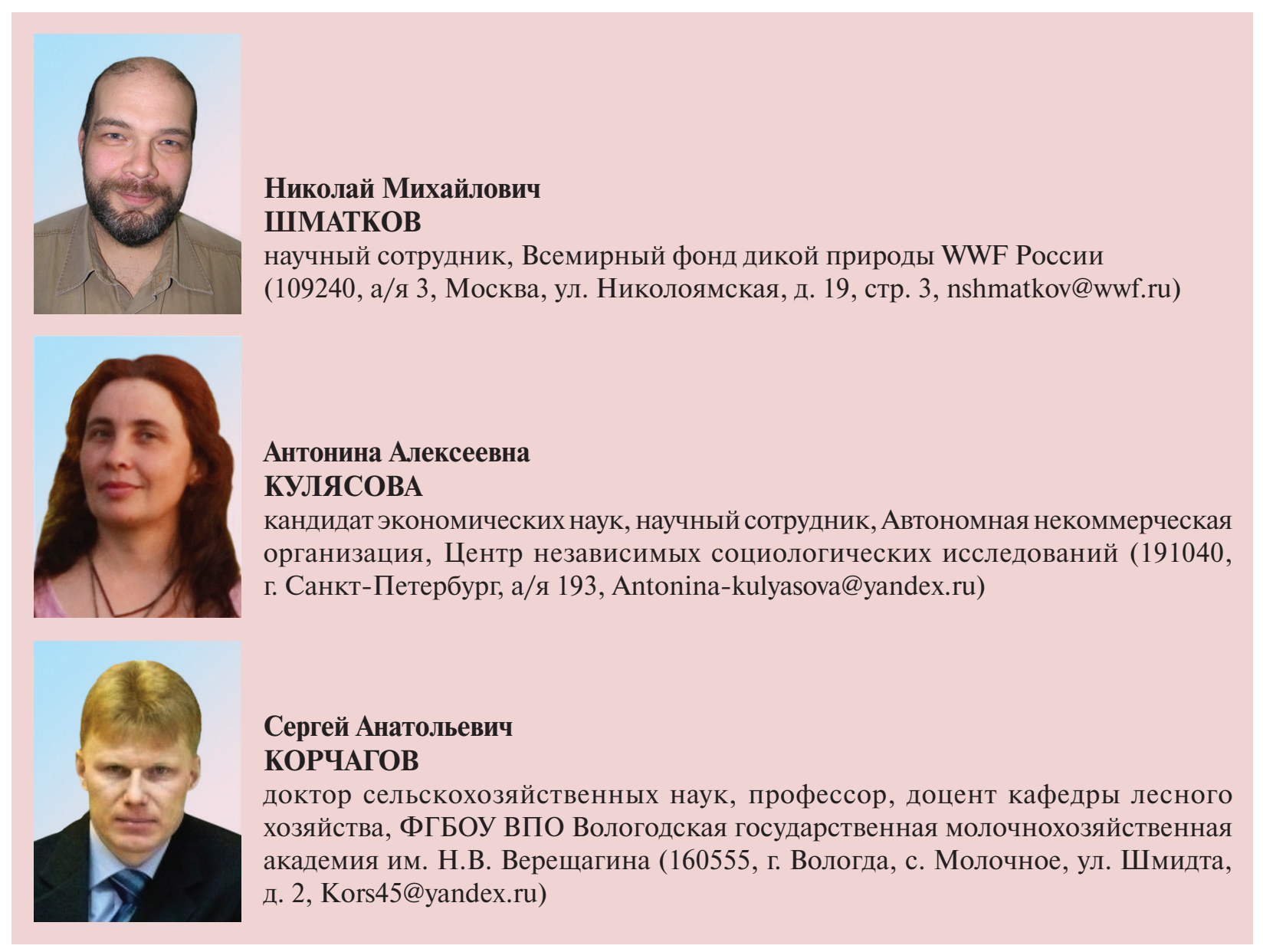

Аннотация. В статье рассмотрены вопросы современного состояния нормативно-правовой базы Российской Федерации и механизма участия общественности в управлении лесами. Приводятся примеры решения проблемы участия населения в управлении лесами в отдельных регионах. Затрагиваются вопросы обеспечения интересов местного населения через систему добровольной лесной сертификации по схеме FSC. Даны рекомендации по совершенствованию механизма участия общественности в решении вопросов лесоуправления.

Ключевые слова: устойчивое управление лесами, участие общественности в управлении лесами, информирование, информационная открытость, Лесной попечительский совет, FSC. 
Shmatkov N.M., Kulyasova A.A., Korchagov S.A.

\section{Regulatory framework and development perspectives of the mechanism of public participation in the management of Russia's forests}

Shmatkov Nikolay Mikhaylovich - Research Associate, the Russian World Wild Fund for Nature, (19, Nikoloyamskaya Street, Building 3, Moscow, 109240, Russia, P.O.B. 3, nshmatkov@wwf.ru)

Kulyasova Antonina Alekseevna - Ph.D. in Economics, Research Associate, Autonomous Non-commercial Organization the Centre for Independent Social Research (Saint Petersburg, 191040, Russia, P.O.B. 193, Antonina-kulyasova@yandex.ru)

Korchagov Sergey Anatol'evich - Doctor of Agricultural Sciences, Professor, Associate Professor at the Forestry Department, Federal State-Financed Educational Institution of Higher Professional Education the Vologda State Dairy Farming Academy Named after N.V. Vereshchagin (2, Schmidt Street, Molochnoye, Vologda, 160555, Russia, Kors45@yandex.ru)

Abstract. The article dwells on the current state of the regulatory framework of the Russian Federation and the mechanism of public participation in forest management. The examples of addressing the problems of public participation in forest management in individual regions are disclosed. The article deals with the issues concerning the provision of in-interests of the local population through the voluntary forest certification system under the FSC scheme. Recommendations on improving the mechanism of public participation in solving the forest management issues are suggested.

Key words: sustainable forest management, public participation in forest management, information sharing, transparency, Forest Stewardship Council, FSC.

Вопрос участия населения в управлении лесами всегда был неразрывно связан с интересами и возможностями людей использовать разнообразные блага, даваемые лесом. В последние десятилетия леса, доступные для многоцелевого лесопользования, использовавшиеся местными жителями на протяжении столетий, стремительно исчезают в результате промышленных рубок.

В настоящее время конкуренция за право рубки экономически доступных лесов со стороны лесопромышленников стала очень жесткой, в рубку им отдаются, в частности, леса, традиционно использовавшиеся для нужд местного населения. При этом в подавляющем большинстве случаев население никак не влияет на решения по использованию лесов. Есть ли сегодня у населения право и возможность влиять на такие решения, принимать участие в лесоуправлении?

В ч. 1 статьи 9 Конституции РФ [2] сказано: «Земля и другие природные ресурсы используются и охраняются в Российской Федерации как основа жизни и деятельности народов, проживающих на соответствующей территории». Согласно ст. 42 Конституции РФ, «каждый имеет право на благоприятную окружающую среду, достоверную информацию о ее состоянии и на возмещение ущерба, причиненного его здоровью или имуществу экологическим правонарушением».

Конституция РФ даёт основу для получения достоверных сведений о состоянии лесных ресурсов и реализации прав местных сообществ на их использование в инте- 
ресах своего развития. Полная реализация прав возможна лишь при участии населения в принятии управленческих решений в сфере лесопользования, для чего должен существовать законодательный механизм, обеспечивающий это право на практике.

На сегодняшний день основным документом, определяющим лесные правоотношения, является Лесной кодекс РФ [3]. В ч. 7 ст. 1 Лесного кодекса РФ участие граждан, общественных объединений в подготовке решений, реализация которых может оказать воздействие на леса при их использовании, охране, защите, воспроизводстве, в установленных законодательством Российской Федерации порядке и формах, регламентируется как основной принцип лесного законодательства.

В соответствии с ч. 2 ст. 1 Лесного кодекса РФ одним из основополагающих принципов лесного законодательства является также сохранение средообразующих, водоохранных, защитных, санитарногигиенических, оздоровительных и иных полезных функций лесов в интересах обеспечения права каждого гражданина на благоприятную окружающую среду. С этой целью выделяются и сохраняются защитные леса (например, зеленые зоны, лесопарки, городские леса, леса в водоохранных зонах и другие), выполняющие эколого-социальные функции. Тем самым обеспечивается конституционное право граждан на благоприятную окружающую среду.

Статья 11 Лесного кодекса РФ «Пребывание граждан в лесах» является важной с точки зрения реализации интересов общества, она подтверждает право людей на использование лесных ресурсов для своей жизни. В соответствии с ч. 1 ст. 11 «граждане имеют право свободно и бесплатно пребывать в лесах и для собственных нужд осуществлять заготовку и сбор дикорастущих плодов, ягод, орехов, грибов, других пригодных для употребления в пищу лесных ресурсов, а также недревесных лесных ресурсов». К сожалению, нередки случаи, когда это требование не выполняется на практике.

В настоящее время основной законодательно закреплённой формой общественного участия в управлении лесами, в том числе в решении социально значимых вопросов, регламентируемых Конституцией РФ и Лесным кодексом РФ, является общественное обсуждение законов. Под общественным обсуждением понимается комплекс мероприятий, направленных на информирование общественности о намечаемой хозяйственной и иной деятельности и ее возможном воздействии на окружающую среду с целью выявления общественных предпочтений и их учета в процессе оценки воздействия.

Общественное обсуждение законопроектов проводится в соответствии с Постановлением Правительства РФ «Об утверждении Правил проведения общественного обсуждения проектов федеральных конституционных законов и федеральных законов» от 22 февраля 2012 г. №159 [4]. Они касаются федеральных законов лесного направления (Лесной кодекс РФ, Водный кодекс РФ, Закон об особо охраняемых природных территориях и другие), подзаконных нормативно-правовых актов (лесные планы субъектов федерации, лесохозяйственные регламенты лесничеств и другие), программ долгосрочного и краткосрочного планирования (например, проекты освоения лесов).

До последнего времени участие общественности в обсуждении ряда документов было закреплено в подзаконных актах. Так, в п. 6 «Положения о подготовке лесного плана субъекта Российской Федерации», введённом в действие Постановлением Правительства РФ от 24 апреля 2007 г. №246 [5], в соответствии со ст. 86 Лесного 
кодекса РФ, указано: «Органы государственной власти субъектов Российской Федерации организуют ознакомление заинтересованных лиц с проектом лесного плана, в том числе путем размешения его на срок не менее 30 дней на официальном сайте высшего исполнительного органа государственной власти субъекта Российской Федерации в сети Интернет. По истечении указанного срока органы государственной власти субъектов Российской Федерации в течение 30 дней осуществляют доработку проекта лесного плана с учетом предложений и замечаний, поступивших от заинтересованных лиц, и направляют его на заключение в Министерство природных ресурсов Российской Федерации». Положение утратило силу согласно Постановлению Правительства РФ от 28 декабря 2011 года № 1183 [6].

Пунктом 12 Приказа МПР РФ «Об утверждении состава лесохозяйственных регламентов, порядка их разработки, сроков их действия и порядка внесения в них изменений» от 19 апреля 2007 года №106 [9], изданного в соответствии со ст. 87 Лесного кодекса РФ, предусматривалась подобная процедура. Приказ обязывал органы государственной власти и местного самоуправления организовать ознакомление заинтересованных лиц с проектом лесохозяйственного регламента и, с учетом поступивших предложений и замечаний, организовать доработку проекта лесохозяйственного регламента и его утверждение. Приказом МПР РФ от 2 апреля 2012 г. №87 [10] настоящий приказ признан утратившим силу.

Приказ МПР РФ «Об утверждении порядка государственной или муниципальной экспертизы проекта освоения лесов» от 14 мая 2007 г. № 125 [11], изданный в соответствии со ст. 89 «Государственная или муниципальная экспертиза проекта освоения лесов» Лесного кодекса РФ, обязы- вал проводить общественное обсуждение проектов освоения лесов.

Общественное обсуждение являлось обязательной процедурой при подготовке к государственной экологической экспертизе. Протоколы общественных слушаний или результаты общественного обсуждения входили в стандартный пакет документов, представлявшихся на экспертизу. Приказом МПР РФ от 10 февраля 2012 г. №33 [12] настоящий приказ также признан утратившим силу.

Механизм участия общественности в принятии решений раскрыт в ст. 19, 20-25 Федерального закона «Об экологической экспертизе» от 23 ноября 1995 г. № 174 [14] и ч. 4 «Положения об оценке воздействия намечаемой хозяйственной и иной деятельности на окружающую среду в Российской Федерации» [13], утвержденного Приказом Госкомэкологии от 16 мая 2000 г. №372 РФ. Однако в соответствии со ст. 11 и 12 ФЗ от 23 ноября 1995 г. № 174 [14] проекты освоения лесов не являются объектами государственной экологической экспертизы.

Ряд объектов, подлежащих экспертизе (особо охраняемые природные территории, полигоны твердых бытовых отходов и другие), могут охватывать лесные участки, в этом случае общественное обсуждение проектов по таким объектам будет связано с лесными вопросами.

Раскроем более подробно положения, обеспечивающие в «Законе об экологической экспертизе» участие общественности. Согласно ст. 3 одними из принципов проведения экспертизы являются «гласность, участие общественных организаций (объединений), учет общественного мнения; организация общественных обсуждений, проведение опросов, референдумов среди населения о намечаемой хозяйственной и иной деятельности, которая подлежит экологической экспертизе». 
Статья 9 раскрывает полномочия органов местного самоуправления в области экологической экспертизы и даёт им право организации по требованию населения общественных экологических экспертиз.

В статье 14, раскрывающей порядок проведения государственной экологической экспертизы, указано, что материалы обсуждений объекта государственной экологической экспертизы с гражданами и общественными организациями (объединениями), организованными органами местного самоуправления, являются обязательной частью документации, предоставляемой для экспертизы.

Глава четвертая рассматриваемого закона посвящена общественной экологической экспертизе, которая может проводиться наряду с государственной экспертизой. Однако, в соответствии с ч. 2 ст. 25, её результаты признаются юридически только при утверждении их федеральным органом исполнительной власти в области экологической экспертизы. На практике проведение общественной экологической экспертизы достаточно затруднительно, так как инициатор хозяйственной деятельности, как правило, затягивает выдачу документов для оценки общественным экспертам, стараясь в первоочередном порядке получить заключение государственной экологической экспертизы.

В связи с тем, что проекты освоения лесов перестали быть объектом государственной экологической экспертизы, общественное обсуждение, несмотря на постулирование участия общественности в управлении лесами в Лесном кодексе РФ, фактически не является обязательной частью принятия основных документов, регулирующих использование лесов. Решения общественных слушаний и предложения общественности не являются обязательными к применению, а могут быть лишь приняты во внимание.
Процесс обсуждения Лесного кодекса, лесных планов субъектов федерации показал, что, несмотря на очень высокий уровень активности граждан, общественных организаций, представителей лесозаготовительных предприятий и самих органов управления лесами, принятие конкретных предложений, исходящих «снизу», было скорее исключением и проходило с большим трудом.

В соответствии с Федеральным законом «О порядке рассмотрения обращений граждан Российской Федерации» от 2 мая 2006 года №59 [15] граждане имеют право обращаться в органы управления лесами и другие государственные органы, связанные с лесом. В соответствии с законом обращение гражданина по любой проблеме должно быть рассмотрено в установленные сроки. Как показывает опыт, обращения граждан по вопросам лесоуправления не многочисленны и часто решаются не в пользу самих граждан. Одной из причин сложившейся ситуации является низкий уровень экологического воспитания населения и его пассивное отношение, в особенности сельских жителей, к происходящим событиям.

Следует упомянуть о некоторых возможностях общественного участия в лесоуправлении, отраженных в Градостроительном кодексе РФ. В соответствии с главой 3 Кодекса органы государственной власти РФ, органы государственной власти субъектов РФ, органы местного самоуправления, заинтересованные физические и юридические лица вправе представлять предложения о внесении изменений в схемы территориального планирования Российской Федерации. Эти изменения лишь частично касаются лесоуправления в отношении планирования новых особо охраняемых природных территорий. 
Существуют показательные примеры действия закона на практике. Так, в Республике Карелия региональной общественной организации СПОК удалось внести свои предложения по особо охраняемым природным территориям в схемы территориального планирования. В Архангельской области Всемирным фондом дикой природы (WWF) вносились свои предложения, которые были приняты частично.

Федеральный закон «Об общих принципах организации местного самоуправления в Российской Федерации» от 6 октября 2003 года № 131 [16] также предоставляет некоторые возможности общественного участия в процессе лесоуправления, однако он ограничивается лесами, находящимися на землях поселений.

Ключевой пробел в российском законодательстве - отсутствие у населения, местных и районных администраций легитимной возможности участвовать в процессе предоставления и передачи лесных участков в любой вид пользования. Своевременное согласование с представителями муниципалитетов и общественности перспективных планов по предоставлению участков в пользование позволит сохранить социально значимые лесные территории.

Важнейшим условием вовлечения общественности в управление лесами является наличие в открытом для общественности доступе информации о лесах [19]. Россия располагает необходимой законодательной базой для обеспечения этого условия. Как указывалось выше, статья 42 Конституции РФ гласит: «Каждый имеет право на благоприятную окружающую среду, достоверную информацию о ее состоянии...» В п. 2 ст. 24 указано, что органы государственной власти и органы местного самоуправления, их должностные лица обязаны обеспечить каждому возможность ознакомления с докумен- тами и материалами, непосредственно затрагивающими его права и свободы. В ст. 29 говорится, что каждый имеет право свободно искать, получать, передавать, производить и распространять информацию любым законным способом.

Обеспечение граждан страны достоверной и полной информацией о состоянии лесов, о деятельности органов государственной власти и управления через Интернет-сайты является не только веянием времени, но и требованием законодательства. Интернет-сайт для органа управления лесами субъекта Российской Федерации это не только «лицо» или представительство в сети, но и важный механизм информирования и вовлечения граждан в управление лесами. Федеральный закон Российской Федерации «Об обеспечении доступа к информации о деятельности государственных органов и органов местного самоуправления» от 9 февраля 2009 года №80 [17] подробно раскрывает эти положения Конституции РФ.

В частности, в П. 1 ст. 10 говорится, что государственные органы, органы местного самоуправления для размещения информации о своей деятельности используют сеть Интернет, в которой создают официальные сайты с указанием адресов электронной почты, по которым пользователем может быть направлен запрос и получена запрашиваемая информация.

Однако информация на сайтах органов управления лесами о состоянии лесов, о деятельности лесопользователей и работе органов управления лесами оставляет желать лучшего. В течение 2010-2011 годов наличие интернет-сайтов у органов государственного управления лесами в субъектах РФ и качество их информационного наполнения привлекали большое внимание природоохранных организаций, входящих в Общественный экологический совет при Рослесхозе. 
Эта тема неоднократно рассматривалась на заседаниях совета, на одном из которых было рекомендовано включить показатели качества интернет-сайтов в независимый рейтинг государственного управления лесами, проводившийся в 2010-2011 гг. Всемирным фондом дикой природы России [1].

Рейтинг WWF показал, что далеко не все субъекты полностью используют потенциал Интернета. У многих органов управления лесами регионального уровня содержание интернет-сайтов не отвечает современным запросам по актуальности и полноте информации как о лесах, так и о деятельности самих органов по использованию, охране и защите лесов. Слабо используются возможности информационной работы среди населения по предупреждению лесных пожаров, а также по разъяснению действующих региональных нормативно-правовых документов.

Региональные нормативные акты принимаются во всех регионах. Однако ознакомиться с ними через Интернет можно на официальных сайтах органов управления лесами менее чем в половине субъектов. Очень сложно требовать выполнения законов и постановлений, когда затруднительно даже ознакомиться с их текстом. Все регионы отчитались о разработке и утверждении лесных планов и лесохозяйственных регламентов. Но менее чем в половине случаев население и другие заинтересованные стороны не могут ознакомиться с этими документами в Интернете. Единичны случаи размещения на сайтах картографических материалов, наиболее полезных общественности и другим заинтересованным сторонам для контроля, например, за легальностью лесопользования.

Рейтинг свидетельствует о ненадежности статистической информации по многим показателям, как предоставляемой регионами, так и имеющейся в открытом доступе. Безусловно, это затрудняет не только вовлечение общественности в управление лесами, но и принятие научно обоснованных управленческих решений самими органами управления лесами, которые вынуждены управлять лесами фактически «вслепую».

Кроме того, в единичных случаях выявлено наличие в субъектах эффективно действующих общественных лесных (экологических) советов при региональных органах управления лесами. Причём Общественный экологический совет Рослесхоза устойчиво работает с 2005 года. Его работа, возможно, не идеальна, но на его заседаниях представители общественных организаций и руководство Рослесхоза регулярно обсуждают наиболее важные и острые проблемы, которые интересуют общественность.

Некоторый опыт вовлечения общественности в процесс управления лесами существует на региональном уровне.

Например, в Республике Коми, под влиянием деятельности Коми регионального фонда «Серебряная Тайга» и модельного леса «Прилузье», общественные слушания были закреплены как обязательная процедура при передаче лесных участков в аренду. Этот опыт имел как положительные, так и отрицательные стороны. Основная отрицательная сторона - это совещательный статус решений общественных слушаний и неготовность местных жителей участвовать в этой процедуре. В случае если решения по слушаниям будут обязательны для исполнения, местное население будет проявлять к ним больший интерес, в результате появится действующий механизм влияния на принимаемые решения. К сожалению, попытки привлечь местное население к решению вопросов передачи лесных участков в пользование не многочисленны и не приносят должного социального эффекта. 
Определенные усилия, направленные на повышение роли общества в решении вопросов лесоуправления, предприняты в Вологодской области. Так, в соответствии с Постановлением областного Правительства «О Концепции содействия развитию институтов гражданского общества в Вологодской области» от 27 декабря 2011 года №1691 [7], Постановлением Губернатора области «О порядке образования общественных советов при органах исполнительной государственной власти области» от 24 декабря 2012 года №686 [8], образован Общественный совет при Департаменте лесного комплекса. Цель создания Совета обеспечение согласования общественно значимых интересов граждан Российской Федерации и находящихся на территории области иностранных граждан и лиц без гражданства, а также институтов гражданского общества и Департамента лесного комплекса Вологодской области. Одной из задач Совета является информирование общественности об основных направлениях деятельности Департамента лесного комплекса области. Создание и развитие советов в регионах (в лесных районах) будет способствовать повышению роли общества в развитии лесных отношений.

Важную роль в развитии социальноориентированного лесоуправления в России играет международная добровольная лесная сертификация по схеме Лесного попечительского совета (FSC). Ее внедрение в систему менеджмента лесозаготовительного предприятия предполагает широкое вовлечение в процесс лесоуправления всех заинтересованных сторон, включая коренные народы (принцип 3), местных жителей и работников предприятия (принцип 4). Дальнейшее развитие лесной сертификации будет способствовать увеличению роли общественности в лесоуправлении.
Тем не менее эффективность реализации подходов FSC тесно зависит от знания населением своих возможностей в рамках этого механизма, а также от его процедур и, в основной степени, от активности местного населения и общественных организаций. К сожалению, далеко не всегда механизмы FSC по защите интересов местного населения оказываются полностью задействованными на сертифицированных территориях.

Учёт интересов местного и коренного населения при внедрении лесной сертификации FSC выражается в первую очередь в возможности сохранения от рубок лесов высокой природоохранной ценности (ЛВПЦ) 5 и 6 типов (в терминологии FSC), или так называемых «социальных лесов». Это леса, необходимые для экономического выживания населения, важные с точки зрения традиционного многоцелевого лесопользования, имеющие иную социальную значимость, в том числе культурную, религиозную, рекреационную и т.д.

Социальные леса - это леса, необходимые для существования местного (сельского, коренного, городского) населения, имеющие особое значение как источник ресурсов для жизни, здоровья и удовлетворяющие материальные и духовные потребности. Такие леса не должны использоваться в промышленных целях, чтобы сохранялся и развивался их социальный потенциал. Соответственно, введение категории социальных лесов должно сопровождаться законодательным блоком, прописывающим участие общественности в управлении этой категорией лесов.

Такое управление должно основываться на традиционных формах общественного управления, присущих разным территориям. Механизмы, формы контроля и 
использования социальных лесов должны обсуждаться на уровне сельских поселений, а затем утверждаться соответствующими законодательными актами районного и регионального уровня.

Отметим, что и сами формы управления социальными лесами могут различаться в зависимости от региональных и местных условий и традиций. Без этого введение новой категории не принесёт должного эффекта.

Первыми площадками для реализации идеи социальных лесов сегодня могут стать создаваемые и действующие особо охраняемые природные территории (ООПТ). Для претворения в жизнь этой идеи необходимо внести соответствующие дополнения о природных парках в раздел 4 «Закона об ООПТ» [18]. Необходимо дополнить ст. 18 этого закона положением о целях создания природных парков как территорий, необходимых для поддержания природнокультурных ландшафтов и традиционного неистощительного природопользования. Кроме того, следует расширить ст. 20 о правовом режиме природных парков, прописав возможности общественного управления наряду с государственным.

Подводя итог всему выше сказанному, отметим, что в России, несмотря на отдельно взятые позитивные моменты, не существует действующий законодательный механизм участия общественности в сфере лесоуправления и лесопользования.

Основными причинами сложившейся ситуации являются:

- отсутствие необходимой нормативно-правовой базы;

- рекомендательный характер принятых ранее решений и предложений;

- отсутствие широкой и адресной информации о возможности публичного обсуждения лесных планов, лесохозяй- ственных регламентов, проектов освоения лесов и других документов для потенциально заинтересованных сторон;

- отсутствие необходимых знаний, навыков и умений у широкой общественности для обсуждения и внесения предложений в рассматриваемые документы;

- незаинтересованность лесозаготовительных предприятий и органов управления лесами, представляющих, соответственно, проекты освоения лесов, лесные планы и лесохозяйственные регламенты, в проведении реального обсуждения и слушаний.

Механизм, способствующий реальному усилению общественного участия в процессе лесоуправления, должен включать:

- законодательное закрепление государственной экологической экспертизы документов лесного планирования, включая лесные планы субъектов РФ, лесохозяйственные регламенты лесничеств и проекты освоения лесов;

- разработку и закрепление процедуры общественных слушаний, предполагающей полную открытость документов лесного планирования для всех заинтересованных сторон, адресное информирование участников, возможность свободного участия всех заинтересованных сторон в обсуждении, понятную и справедливую схему внесения поступивших предложений;

- разработку и внедрение процедуры согласования с представителями муниципалитетов и общественности перспективных планов по предоставлению участков в пользование;

- создание и развитие лесных общественных советов в регионах (в лесных районах), способствующих повышению роли общества в развитии лесных отношений;

- повышение уровня информированности населения в вопросах участия обще- 
ственности в процессе лесоуправления и лесопользования;

- открытость всех документов лесного планирования (в первую очередь планов рубок), включая картографические материалы, на сайтах органов управления лесами;

- широкое внедрение систем добровольной лесной сертификации, ориентированных на повышение социальной роли лесов;
- расширение перечня категорий лесов за счет выделения категории «социальные леса».

Активное участие населения в подготовке и принятии решений на всех уровнях управления - один из важнейших инструментов достижения баланса между всеми заинтересованными сторонами при использовании лесов и основа демократического развития государства и гражданского общества.

\section{Литература}

1. Григорьев, А.Ю. Рейтинг WWF «Информационное содержание интернет-сайтов органов государственного управления лесами субъектов Российской Федерации» 2011 года / А.Ю. Григорьев, К.А. Пахорукова, Н.M. Шматков; под общ. ред. Н.M. Шматкова; Всемирный фонд дикой природы (WWF). M., 2012.

2. Конституция РФ 1993 г.

3. Лесной кодекс РФ: утв. ФЗ от 4 декабря 2006 г. №200.

4. Постановление Правительства РФ «Об утверждении Правил проведения общественного обсуждения проектов федеральных конституционных законов и федеральных законов» от 22 февраля 2012 г. № 159.

5. Постановление Правительства РФ «Положение о подготовке лесного плана субъекта Российской Федерации» от 24 апреля 2007 г. №246.

6. Постановление Правительства РФ «О признании утратившими силу постановлений Правительства Российской Федерации от 24 апреля 2007 г. №246 и от 17 ноября 2007 г. №782» от 28 декабря 2011 г. № 1183.

7. Постановление Правительства Вологодской области «О Концепции содействия развитию институтов гражданского общества в Вологодской области» от 27 декабря 2011 г. №1691.

8. Постановление Губернатора Вологодской области «О порядке образования общественных советов при органах исполнительной государственной власти области» от 24 декабря 2012 г. №686.

9. Приказ МПР России «Об утверждении состава лесохозяйственных регламентов, порядка их разработки, сроков их действия и порядка внесения в них изменений» от 19 апреля 2007 г. № 106.

10. Приказ МПР России «О признании утратившим силу приказа МПР России от 19 апреля 2007 г. №106» от 2 апреля 2012 г. №87.

11. Приказ МПР России «Об утверждении порядка государственной или муниципальной экспертизы проекта освоения лесов» от 14 мая 2007 г. № 125.

12. Приказ МПР России «О признании утратившим силу приказа МПР России от 14 мая 2007 г. №125» от 10 февраля 2012 г. №33.

13. Приказ Госкомэкологии РФ «Положение об оценке воздействия намечаемой хозяйственной и иной деятельности на окружающую среду в Российской Федерации» от 16 мая 2000 г. №372.

14. Федеральный закон «Об экологической экспертизе» от 23 ноября 1995 г. № 174.

15. Федеральный закон «О порядке рассмотрения обращений граждан Российской Федерации» от 2 мая 2006 г. №59.

16. Федеральный закон «Об общих принципах организации местного самоуправления в Российской Федерации» от 6 октября 2003 г. №131.

17. Федеральный закон «Об обеспечении доступа к информации о деятельности государственных органов и органов местного самоуправления» от 9 февраля 2009 г. №80.

18. Федеральный закон «Об особо охраняемых природных территориях» от 14 марта 1995 г. №33.

19. Шматков, Н.М. Вовлечение общественности в управление лесами в США и России: проблемы и перспективы / Н.М. Шматков // Устойчивое лесопользование. - 2011. - №2 (27). - С. 2-14. 


\section{Referenses}

1. Grigor'ev A.Yu., Pakhorukova K.A., Shmatkov N.M. Reyting WWF “Informatsionnoe soderzhanie internet-saytov organov gosudarstvennogo upravleniya lesami sub"ektov Rossiyskoy Federatsii” 2011 goda [WWF Rating "The Information Content of Websites of the State Forest Management Bodies of the Subjects of the Russian Federation in 2011]. Under general editorship of N.M. Shmatkov; Vsemirnyy fond dikoy prirody (WWF) [World Wide Fund for Nature (WWF)]. Moscow, 2012.

2. Konstitutsiya RF 1993 g. [The Constitution of the Russian Federation, 1993].

3. Lesnoy kodeks RF: utv. FZ ot 4 dekabrya 2006 g. №200 [The Forest Code of the Russian Federation: Approved by the Federal Law of December 4, 2006 No.200].

4. Postanovlenie Pravitel'stva RF “Ob utverzhdenii Pravil provedeniya obshchestvennogo obsuzhdeniya proektov federal'nykh konstitutsionnykh zakonov i federal'nykh zakonov” ot 22 fevralya 2012 g. №159 [RF Government Resolution "On the Approval of the Rules for Holding Public Discussions of Draft Federal Constitutional Laws and Federal Laws" of February 22, 2012 No.159].

5. Postanovlenie Pravitel'stva RF “Polozhenie o podgotovke lesnogo plana sub”ekta Rossiyskoy Federatsii” ot 24 aprelya 2007 g. №246 [RF Government Resolution "Regulations on the Preparation of the Forest Plan of the Subject of the Russian Federation” of April 24, 2007 No.246].

6. Postanovlenie Pravitel'stva RF “O priznanii utrativshimi silu postanovleniy Pravitel'stva Rossiyskoy Federatsii ot 24 aprelya $2007 \mathrm{~g}$. №246 $i$ ot 17 noyabrya 2007 g. №782” ot 28 dekabrya 2011 g. №1183 [RF Government Decree "On the Invalidation of the Resolutions of the Russian Federation Government of April 24, 2007 No.246 and of November 17, 2007 No.782” of December 28, 2011 No. 1183.].

7. Postanovlenie Pravitel'stva Vologodskoy oblasti “O Kontseptsii sodeystviya razvitiyu institutov grazhdanskogo obshchestva v Vologodskoy oblasti” ot 27 dekabrya 2011 g. №1691 [Resolution of the Vologda Oblast Government "On the Concept for Promoting the Development of Civil Society Institutions in the Vologda Oblast" of December 27, 2011 No.1691].

8. Postanovlenie Gubernatora Vologodskoy oblasti "O poryadke obrazovaniya obshchestvennykh sovetov pri organakh ispolnitel'noy gosudarstvennoy vlasti oblasti” ot 24 dekabrya 2012 g. №686 [Decree of the Vologda Oblast Governor "On the Order of Formation of Public Councils under the Executive Power of the Oblast" of December 24, 2012 No.686].

9. Prikaz MPR Rossii "Ob utverzhdenii sostava lesokhozyaystvennykh reglamentov, poryadka ikh razrabotki, srokov ikh deystviya i poryadka vneseniya v nikh izmeneniy” ot 19 aprelya 2007 g. №106 [The Order of the Ministry of Natural Resources and Environment of the Russian Federation "On the Approval of Forestry Regulations, the Procedure for Their Preparation, the Period of Their Validity and the Order of Introducing Amendments in Them" of April 19, 2007 No.106].

10. Prikaz MPR Rossii “O priznanii utrativshim silu prikaza MPR Rossii ot 19 aprelya 2007 g. №106” ot 2 aprelya 2012 g. №87 [The Order of the Ministry of Natural Resources and Environment of the Russian Federation "On the Invalidation of the Order of the Ministry of Natural Resources and Environment of the Russian Federation of April 19, 2007 No.106” of April 2, 2012 No. 87].

11. Prikaz MPR Rossii “Ob utverzhdenii poryadka gosudarstvennoy ili munitsipal’noy ekspertizy proekta osvoeniya lesov” ot 14 maya 2007g. №125 [The Order of the MNR of Russia “On the Approval of the State or Municipal Examination of the Forest Development Project” of May 14, 2007 No.125].

12. Prikaz MPR Rossii “O priznanii utrativshim silu prikaza MPR Rossii ot 14 maya 2007g. №125” ot 10 fevralya 2012 g. №33 [The Order of the MNR of Russia "On the Invalidation of the Order of the MNR of Russia of May 14, 2007 No.125” of February 10, 2012 No.33].

13. Prikaz Goskomekologii RF "Polozhenie ob otsenke vozdeystviya namechaemoy khozyaystvennoy i inoy deyatel'nosti na okruzhayushchuyu sredu v Rossiyskoy Federatsii” ot 16 maya 2000g. №372 [The Order of the State Committee on Environmental Protection "Regulation on the Assessment of Impact of Planned Economic and Other Activity on Environment in the Russian Federation" of May 16, 2000 No.372].

14. Federal’nyy zakon “Ob ekologicheskoy ekspertize” ot 23 noyabrya 1995 g. №174 [Federal Law “On Ecological Expert Examination" of November 23, 1995 No.174)].

15. Federal'nyy zakon "O poryadke rassmotreniya obrashcheniy grazhdan Rossiyskoy Federatsii” ot 2 maya 2006 g. №59 [Federal Law “On the Order of Consideration of Appeals of the Russian Federation Citizens” of May 02, 2006 No.59]. 
16. Federal'nyy zakon "Ob obshchikh printsipakh organizatsii mestnogo samoupravleniya $v$ Rossiyskoy Federatsii" ot 6 oktyabrya 2003 g. №131 [Federal Law “On General Principles of Organization of Local Government in the Russian Federation” of October 06, 2003 No.131].

17. Federal'nyy zakon "Ob obespechenii dostupa $k$ informatsii o deyatel'nosti gosudarstvennykh organov i organov mestnogo samoupravleniya” ot 9 fevralya 2009 g. №80 [Federal Law "On the Provision of Access to Information about the Activity of State Bodies and Local Government Bodies" of February 09, 2009 No.80].

18. Federal'nyy zakon "Ob osobo okhranyaemykh prirodnykh territoriyakh" ot 14 marta 1995 g. №33 [Federal Law "On Specially Protected Natural Areas" of March 14, 1995, No.33].

19. Shmatkov N.M. Vovlechenie obshchestvennosti v upravlenie lesami v SShA i Rossii: problemy i perspektivy [Public Involvement in Forest Management in the USA and Russia: Problems and Prospects]. Ustoychivoe lesopol'zovanie [Sustainable Forest Management], 2011, No.2(27), pp. 2-14. 


\section{Региональный социальный капитал и множественная модернизация в России. К постановке проблемы*}

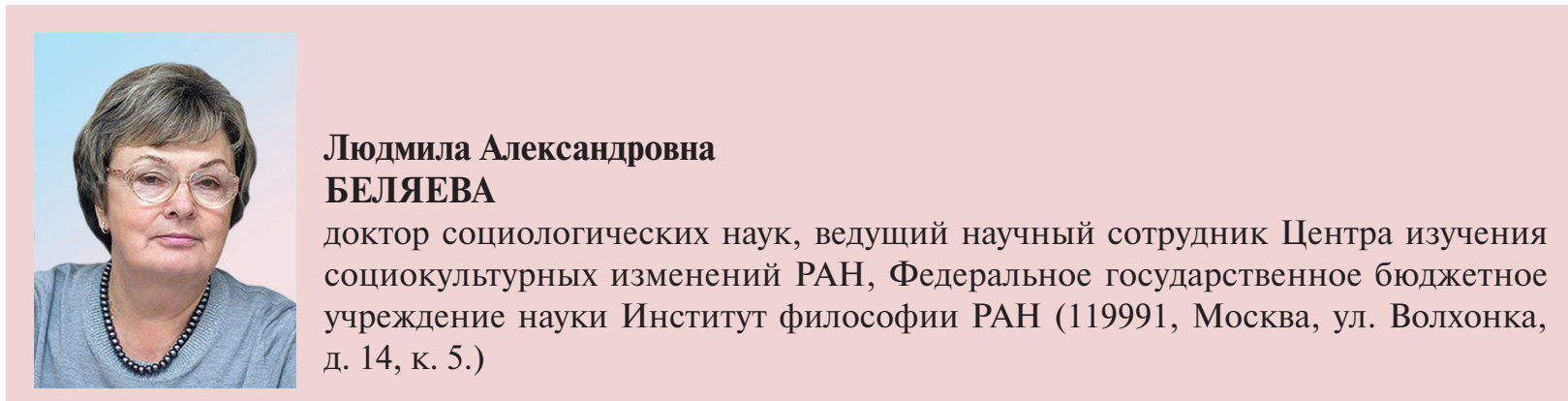

Аннотация. В статье поставлены проблемы взаимосвязи множественной модернизации и социального капитала в регионах России. Социальный капитал рассматривается как фактор, обусловливающий особенности и темпы модернизации, показаны возможности измерения социального капитала и необходимость разработки адекватных условиям России показателей для составления социокультурных портретов регионов.

Ключевые слова: модернизация, социальный капитал, измерение социального капитала.

Belyaeva L.A.

\section{Regional social capital and multiple modernization in Russia. On defining the problem}

Belyaeva Lyudmila Aleksandrovna - Doctor of Sociology, Leading Research Associate at the RAS Centre for the Study of Social and Cultural Change, Federal State-Financed Scientific Institution the Institute of Philosophy of the Russian Academy of Sciences (14, Volkhonka Street, Moscow, 119991, Russia).

Abstract. The article raises the issues of relationship between multiple modernization and social capital in Russia's regions. Social capital is considered as a factor that determines the specifics and pace of modernization. The article also shows the ways to measure social capital and the necessity to develop the indicators for making socio-cultural portraits of the regions with regard to Russia's conditions.

Keywords: modernization, social capital, measurement of social capital.

\footnotetext{
* Статья подготовлена в рамках проекта РГНФ № 14-03-00338а.
} 
В современном политическом и социологическом дискурсе все более активно развиваются идеи о множественном характере модернизации в мире, в том числе и в России. Применительно к российскому обществу эти идеи особенно актуальны, поскольку они падают на такую почву, которая характеризуется огромным разбросом экономических условий, социокультурного опыта, традиций, обычаев, уровня поликультурности и поликонфессиональности, ценностных систем и политических проектов. В данной статье будет уделено внимание множественности модернизации как производной от состояния социального капитала региона. Теперь становится все более очевидным, что экономический рост обеспечивается не только наличием материальных, финансовых, человеческих, культурных ресурсов, не все современные институты развития приживаются в обществе и тем более во всех регионах страны и оказывают на развитие ожидаемое действие. Существует нечто, что препятствует успешной модернизации. Это нечто вновь и вновь возрождается, когда ослабевает административное воздействие и контроль. Характерный пример - ситуация в регионах России.

В советский период уровни развития человеческого и культурного капиталов в регионах в значительной мере были выравнены: сходные показатели имели образование населения, квалификация, профессиональная и социальная структура, отсутствовала или была небольшой безработица (по крайней мере, явная), существовала близкая по своим функциям система государственных институтов. Плановая экономическая политика, главенствующая роль государства содействовали постепенному выравниванию уровней развития регионов, осуществлялась плановая модернизация отстающих регионов и территорий, хотя и в советский период существовали более развитые и менее развитые из них.
Кроме того, в прошлом действовал единый идеологический масштаб взаимоотношений в обществе, который связывал субъекты экономических отношений, предписывая им нормы поведения, прививая такую систему ценностей, которая отвечала принципам коллективизма, подавления индивидуальности и личных интересов в пользу интересов общественных. Даже если учитывать формализм и поверхностность влияния идеологической пропаганды и контроля в последние годы, то можно сказать, что в обществе существовал довольно высокий уровень доверия между людьми и доверия институтам общества, что играло свою роль в выполнении экономических планов.

C переходом к рыночной экономике большие надежды возлагались на развязывание творческой инициативы, раскрытие индивидуальности через реализацию частного интереса. Действительно, предпринимательство, индивидуальная трудовая деятельность опираются на эти принципы, но вместе с воплощением индивидуального, частного интереса в нашей стране оказались низведенными до минимального уровня ценности общественного взаимодействия, доверия между людьми, социальными группами и доверия институтам общества. Рыночные или псевдорыночные отношения зачеркнули иные мотивы взаимоотношений в экономике, кроме экономического интереса.

А это то, что составляет важную часть социального капитала. Можно априори утверждать, что особенности и темпы модернизации в России и в регионах определяются характером и особенностями социального капитала, созданного в последние два десятилетия. Мономодернизация как проект демократического и либерального развития применительно ко всем регионам России не может быть успешной, в том числе и в силу особенностей социального капитала этих регионов. 
Почему же именно социальный капитал оказывает такое плюральное воздействие на модернизацию? Разобраться в этом можно, если понять, что же такое социальный капитал. Простейшее определение социального капитала: это система отношений между людьми, группами, организациями, институтами, которая дает выгоды от сотрудничества, увеличивает результативность прилагаемых усилий. Проблемы социального капитала стали активно обсуждаться в последние 15 лет экономистами, социологами и политологами. Это понятие востребовано в междисциплинарных исследованиях. В отечественных публикациях основное внимание уделяется интерпретациям работ зарубежных специалистов и делаются отдельные попытки проследить существование и влияние социального капитала на локальные сферы общества.

Представим основные точки зрения на эту проблему, основываясь на взглядах тех ученых, которые положили начало ее разработке. Это прежде всего работы П. Бурдье, Р. Патнэма, Дж. Коулмена, Ф. Фукуямы и некоторых других ученых. Между их подходами существуют различия, и пока не выработано общей позиции в интерпретации концепта «социальный капитал», методов его измерения и оценок воздействия на развитие общества. В чем сходны позиции исследователей, так это в исключении из социального капитала государственных институтов. Но институты общественные, институты гражданского общества - его неотъемлемая часть, более того, накопление социального капитала создает предпосылки для становления и развития гражданского общества. Всемирный банк, который проводит исследование проблем социального капитала в отдельных странах, определяет социальный капитал как «институты, отношения и нормы, которые формируют качественно и количественно социальное взаимодействие в обществе». Всемирный банк начал этот проект в 1996 г., и сейчас уже проведено несколько региональных исследований в различных странах мира, а самое главное - осуществляется международный сравнительный проект в большинстве стран мира. В России этот проект не институализирован.

Одним из первых понятие «социальный капитал» сформулировал Пьер Бурдье, который отметил, что социальный капитал это ресурсы, основанные на родственных отношениях и отношениях в группе членства. Социальный капитал дает преимущества, выгоды членам группы, является основой групповых солидарностей [1, с. 21]. Социальный капитал воплощается в социальных сетях, социальных нормах поведения, взаимных поддержках и кооперациях ради получения взаимной выгоды. Бурдье показывает, что социальный капитал может быть использован для производства и воспроизводства неравенства путем доступа к занятию более высокого места в иерархии через использование социальных связей.

Джеймс Коулмен первым концептуально проработал понятие «социальный капитал», отметив, что в «отличие от иных форм капитала, социальный капитал свойствен структуре связей между акторами и среди них. Организации, преследующие определенные цели, могут быть акторами (так называемый корпоративный актор), так же как и индивид. Связи внутри корпоративных акторов также могут создавать для них социальный капитал» [2, с. 124]. Коулмен определил сущность социального капитала, отличающую его от других форм капитала, как способность создавать общественное благо, поскольку актор или акторы, создающие социальный капитал, обычно получают только малую его часть. Этим объясняется то, с какой неохотой вкладываются инвестиции в социальный капитал. 
Коулмен считал, что социальный капитал - это только потенциал взаимного доверия и взаимопомощи, целерационально формируемый в межличностных отношениях: обязательства и ожидания, которые зависят от надежности социальной среды, информационные каналы социальной структуры и их способность к передаче информации и социальные нормы, нарушение которых сопровождается санкциями. Социальный капитал - это то, что облегчает индивидуальные или коллективные действия, генерирует сети отношений, взаимности, доверия и социальные нормы [2, c. 138].

Социальный капитал как характеристику взаимоотношений индивидов, других акторов довольно сложно оценить и измерить, поскольку он, как будет показано ниже, имеет сложную структуру и вследствие этого разную результативность, к тому же он действует в неодинаковых социальных контекстах. И все же социальный капитал оказывает воздействие на экономическое развитие, что продемонстрировали межстрановые и региональные исследования.

Одно из таких исследований провел в Италии Р. Патнэм. Он определяет социальный капитал как «уходящие в глубь истории традиции социального взаимодействия, предполагающие нормы взаимности и доверия между людьми, широкое распространение различного рода добровольных ассоциаций и вовлечение граждан в политику ради решения стоящих перед сообществом проблем» [3, с. 124]. Р. Патнэм изучает социальный капитал и горизонтальные связи людей и организаций преимущественно в позитивном ключе как стимулы и условия для утверждения демократии, считая, что они являются мерой общественного здоровья. Он связывает экономическое развитие с наличием разных объемов социального капитала.
Р. Патнэм разработал трехфакторную модель социального капитала: нормы взаимности, доверие и социальные сети, которая позволяет измерять социальный капитал с помощью индивидуальных индикаторов. Посредством их агрегации получаются групповые или территориальные показатели. Возникло такое понятие, как «группы Патнэма» - это те группы, которые работают на улучшение жизни других людей и всего общества. В отличие от этих групп существуют группы Олсона [4] - те, которые преследуют собственные цели и вступают с другими группами в конкурентную борьбу за обладание ограниченными ресурсами, используя свой социальный капитал для получения ренты, но не для общего развития. И это сдерживает экономический рост.

Френсис Фукуяма определяет социальный капитал как набор неформальных норм взаимодействия, которые способствуют сотрудничеству между двумя и более лицами [5]. Потенциально эти нормы существуют в отношениях со всеми людьми, но актуализируются они только в реальных человеческих отношениях. Фукуяма, полемизируя с Патнэмом, обратил внимание на то, что внешнее влияние социального капитала группы может быть и положительным и отрицательным. Он приводит пример Ку-Клукс-Клана или мафиозных структур. Такие группы тоже имеют определенные нормы и сети, которые позволяют им достигать своих коллективных целей, в этом смысле они тоже обладают социальным капиталом. Но их воздействие на большое общество - негативное. «У общественного капитала, этого материализованного доверия, играющего принципиальную роль в создании здоровой экономики, культурные корни. Поскольку и по своему существу, и по своему бытованию культура есть нечто абсолютно нерациональное, утверждение, что она влияет на экономи- 
ческую эффективность, может на первый взгляд показаться парадоксальным. Действительно, в качестве предмета научного исследования она постоянно обнаруживает свою неуловимость» [6, с. 65].

Этические принципы в формировании социального капитала приобретают особую значимость в современной России, когда произошла смена общественных ориентиров и были ослаблены идеологические скрепы общественной жизни. Добросовестность, честность, искренность, правдивость - это те этические правила, которые способствуют росту социального капитала. Напротив, ложь, притворство, обман разрушают социальный капитал.

Практически все исследователи социального капитала отмечают его тройственную структуру: нормы, доверие, сети. Все эти элементы связаны друг с другом: сети необходимы для передачи информации, налаживания контактов, они способствуют распространению норм взаимодействия; нормы и доверие укрепляют и содействуют расширению сетей и контактов и снижению трансакционных издержек при взаимодействии.

Можно выделить три уровня социального капитала. Первый уровень - частный социальный капитал, которым обладает индивидуум по факту своего рождения, принадлежности к семье, этническому сообществу, «малой родине», землячеству или являясь членом какой-то малой группы и т.д.; второй уровень - предприятия, организации, корпорации; третий уровень общественные организации, профессиональные объединения, международные сообщества и другие негосударственные организации.

Социальный капитал можно рассматривать, по меньшей мере, в двух измеряемых масштабах. Первый - это капитал общностей, которые влияют на получение выгод во вне себя, они дают импульсы совершенствованию тех или иных сторон жизни ближайшего или дальнего окружения. Можно считать, что он имеет «большие круги» влияния, способствующие формированию для всего общества системы гражданских институтов, норм, ценностей.

Второй масштаб - это социальный капитал небольших, как правило, закрытых общностей, к которым относятся семья, этническая община, клан, землячество, предприятие, корпорация и т.д. Этот капитал формируется внутри общности, но он используется для адаптации и преуспевания во внешнем мире. Круги влияния этого капитала небольшие, но он способствует выживанию группы, мобилизует ресурсы для коллективной защиты и развития. Важно изучать и учитывать в модернизации такую разновидность этого капитала, как капитал традиционных сообществ, особенно Юга России. Он ориентирован на воспроизводство накопленного исторического и бытового опыта, нравов, обрядов, технологий жизнеобеспечения и социальной активности. Традиционный капитал базируется на авторитете этнических норм, во многом обусловливает низкий уровень общего социально-культурного развития, бедность, незначительную урбанизированность, слабость современной индустрии. Для этого региона характерна множественность неформальных сетей, пронизывающих хозяйственную жизнь местных этнических сообществ, которая отчасти служит фактором стабилизации и выживания [7, с. 109-117]. Вместе с тем значимость неформальных сетей в социальном капитале этого региона создает значительные трудности для его модернизации.

Роль социального капитала в решении проблем модернизации общества нельзя переоценивать, как нельзя им и пренебрегать. 
При решении задач модернизации можно сделать ставку на проведение институциональных реформ, повышать активность государственных органов. Но в современной России, в отсутствие или из-за слабости гражданского общества, государственные институты не могут эффективно выполнять свои функции, поскольку они не контролируются обществом и не корректируют свою деятельность в соответствии с общественными потребностями в силу отсутствия обратной связи. Контроль «сверху» привычен, но неэффективен, если нет контроля «снизу». Сильное государство - не обязательно эффективное государство.

Различия в объемах, структуре и качестве социального капитала необходимо учитывать при разработке стратегии модернизации каждого региона. Разный уровень готовности регионов к демократии и самоуправлению - это отправная точка в наращивании социального капитала в соответствии с традициями и опытом социального взаимодействия. В тех из них, где слабы или отсутствуют «группы Патнэма», работающие на общее благо, могут доминировать «группы Олсона», работающие на внутренние интересы групп. Эти последние группы часто носят криминальный или антиобщественный характер. Под их воздействием подвергаются коррозии государственные функции управления, т.к. на них оказывают влияние частные или узкогрупповые интересы.

Социальный капитал существует в двух формах: институциональной - как общественные объединения, организации, органы самоуправления и когнитивной - как правила поведения, нормы, ценности, доверие между людьми и институтами. Социальный капитал возрастает, когда он используется, и, напротив, сокращается, если он остается без употреб- ления. Он может быть полностью утрачен при определенных обстоятельствах, например, связанных с утратой доверия к субъекту отношений. Но даже на тех территориях и в регионах, где слаб, не развит социальный капитал, можно его укреплять и выращивать, поддерживая общественные объединения, вступая с ними в продуктивный диалог, и, напротив, можно уничтожить его даже слабые ростки, создав невыносимые для него условия, прибегая к шантажу, перекрытию финансовых источников существования и к другим формам репрессий. Процесс модернизации как множественной модернизации, или, если использовать термин Зигмунта Баумана, «жидкой» или «текучей» модернизации, находится в зависимости от состояния социального капитала страны и регионов.

\section{Проблемы измерения социального капи- maла}

Для измерения социального капитала необходимо располагать количественными индикаторами последнего, но определить их довольно сложно, поскольку речь идет о нематериальных и далеко не всегда доступных прямому наблюдению характеристиках. Поэтому социологи прибегают, как правило, к вербальным свидетельствам наличия социального капитала. Существует, например, система показателей, которые были разработаны в исследовании Всемирного банка.

Некоторый материал для сравнительного анализа социального капитала в России может дать Европейское социальное исследование (ESS) [8], прежде всего по проблемам доверия в обществе. Доверие является ядром социального капитала. Три вопроса в анкете предлагают оценить по 10-балльной шкале доверие между людьми. Индекс образован мною как среднее арифметическое этих оценок 


\section{Индекс доверия (средний балл по 10-балльной шкале) ESS-2010}

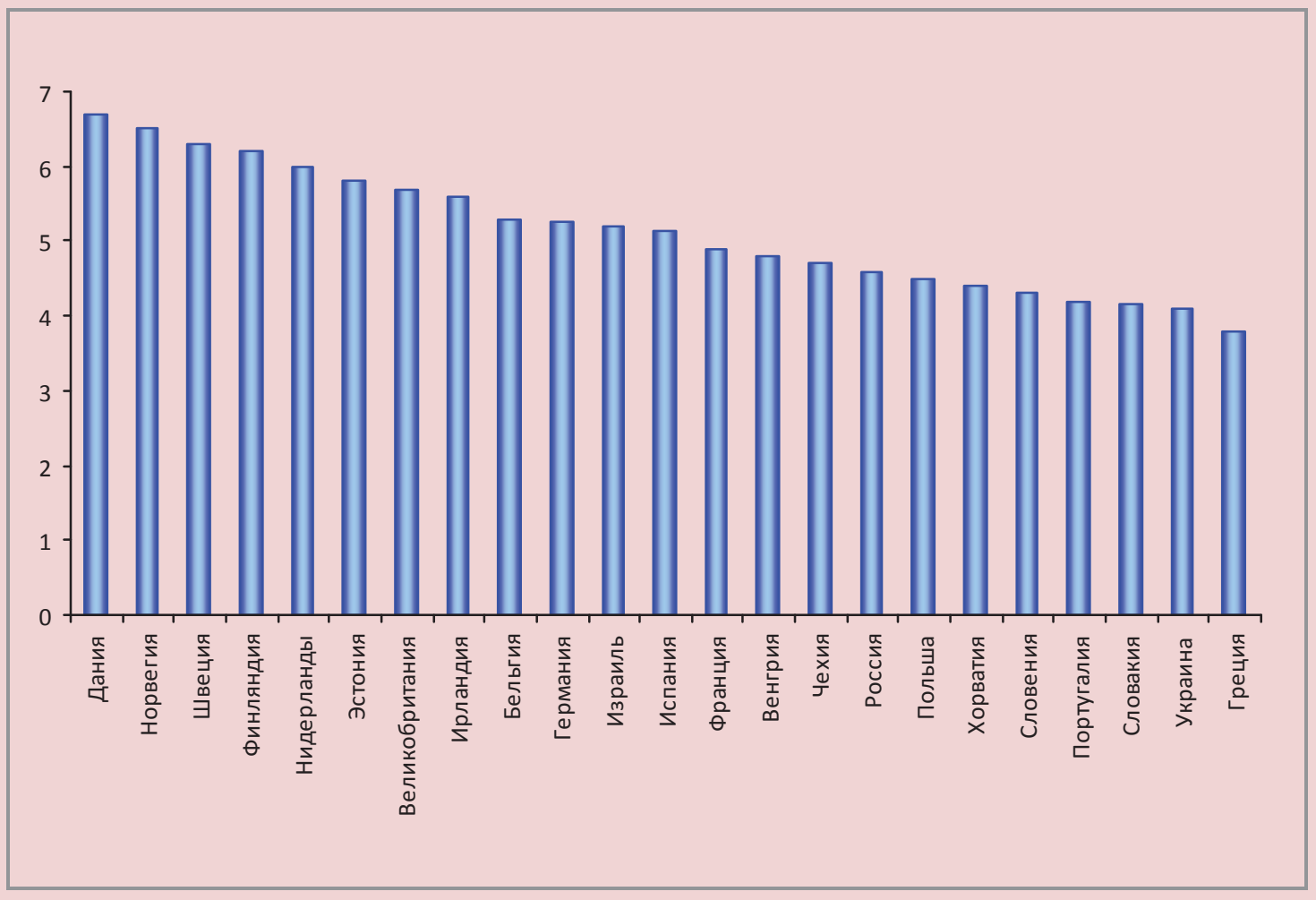

(рисунок). Как видим, Россия занимает 16 -е место с индексом 4,47, опережая только 7 стран из 23-х. Впереди России большинство стран с более высоким уровнем модернизации. Максимальный уровень доверия в Дании - 6,45.

Интересные наблюдения, характеризующие круги близкого общения в семье, с друзьями, с коллегами, в России и других странах, участвующих в ESS, можно получить, обратившись к ответам на вопрос: Как часто Вы проводите время с друзьями, родственниками или коллегами по работе просто так, не по делам? Оказалось, что наиболее общительными являются жители высокоразвитых, модернизированных стран: один раз в неделю и чаще такие встречи происходят у $91 \%$ жителей Швейцарии, более чем у $70 \%$ жителей Бельгии, Дании, Нидерландов, Норвегии, Швеции. Часто общаются также португальцы (79\%), израильтяне $(77 \%)$ и испанцы $(74 \%)$, что объясняется традиционно близкими отношениями в южных регионах.

Но жители других стран заметно реже участвуют в таких встречах. Россия по этому показателю на предпоследнем месте с 46\%, что превышает уровень общения только в одной стране - Венгрии (32\%). Разобщенность и атомизация общества в России достигла высокого уровня: даже в семье не находят понимания от 30 до $60 \%$ респондентов в разных регионах.

Можно с уверенностью сказать, что общества с развитым социальным капиталом, включающим высокий уровень доверия, сильную гражданскую идентичность, позитивные социальные связи и отношения, имеют более благоприятные возможности для модернизации, особенно современной - вторичной модернизации. 


\section{Литература}

1. Bourdieu, P. The forms of capital / P. Bourdieu // Handbook of theory and research for sociology of Education. Ed. by J. Richardson. - New York: Greenwood Press, 1986. - P. 21.

2. Коулмен, Дж. Капитал социальный и человеческий / Дж. Коулмен // Общественные науки и современность. - 2001. - №3. - С. 124.

3. Патнэм, Р. Чтобы демократия сработала. Гражданские традиции в современной Италии / Р. Патнэм. - 1996. - C. 224.

4. Olson, M. The Logic of Collective Action: Public Goods and the Theory of Groups / M. Olson. - Cambridge, MA: Harvard University Press, 1965.

5. Fykuyama, F. Social Capital and Civil Society. Prepared for delivery at the IMF Conference on Second generation reforms / F. Fykuyama. - URL.: http://www.imf.org/external/pubs/ft/seminar/1999/reforms/fukuyama.htm

6. Фукуяма, Ф. Доверие: социальные добродетели и путь к процветанию: пер. с англ. / Ф. Фукуяма. М.: ООО «Издательство АСТ»: ЗАО НПП «Ермак», 2004. - С. 65

7. Лебедева, Н.Н. Социальный капитал и модернизация этноэкономики Юга России / Н.Н. Лебедева, О.А. Ломонцева // Общественные науки и современность. - 2006. - №2.

8. Россия в Европе: по материалам международного проекта «Европейское социальное исследование» / под общ. ред. А.В. Андреенковой и Л.А. Беляевой. - М., 2009.

\section{References}

1. Bourdieu P. The Forms of Capital. Handbook of Theory and Research for Sociology of Education. Ed. by J. Richardson. New York: Greenwood Press, 1986. P. 21.

2. Koleman J. Kapital sotsial'nyy i chelovecheskiy [Social and Human Capital]. Obshchestvennye nauki $i$ sovremennost' [Social Sciences and Modernity], 2001, no. 3, p. 124.

3. Putnam R. Making Democracy Work: Civic Traditions in Modern Italy. 1996. P. 224.

4. Olson M. The Logic of Collective Action: Public Goods and the Theory of Groups. Cambridge, MA: Harvard University Press, 1965.

5. Fykuyama F. Social Capital and Civil Society. Prepared for delivery at the IMF Conference on Second generation reforms. Available at: http://www.imf.org/external/pubs/ft/seminar/1999/reforms/fukuyama.htm

6. Fukuyama F. Trust: The Social Virtues and The Creation of Prosperity [Doverie: sotsial'nye dobrodeteli i put' k protsvetaniyu]. Translated from English. Moscow: OOO “Izdatel'stvo ACT”: ZAO NPP “Ermak", 2004. P. 65.

7. Lebedeva N.N., Lomontseva O.A. Sotsial'nyy kapital i modernizatsiya etnoekonomiki Yuga Rossii [Social Capital and Modernization of Etnoeconomy in the North of Russia]. Obshchestvennye nauki i sovremennost' [Social Sciences and Modernity], 2006, no.2.

8. Rossiya v Evrope: po materialam mezhdunarodnogo proekta "Evropeyskoe sotsial'noe issledovanie" [Russia in Europe: on the Materials of the International Project "European Social Survey"]. Under general editorship of A.V. Andreenkova and L.A. Belyaeva. Moscow, 2009. 


\section{Экономическое поведение: анализ и перспективы*}

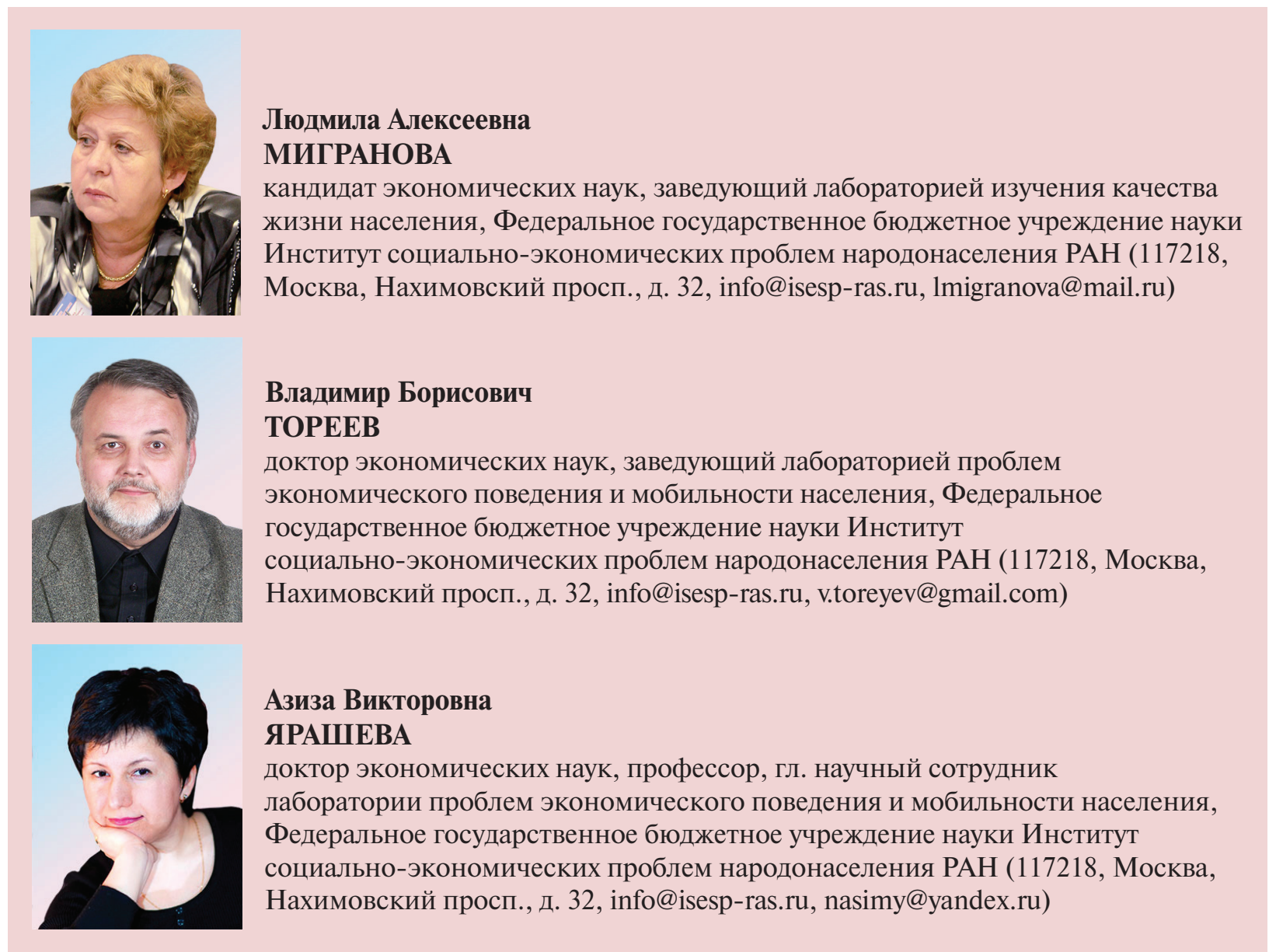

Аннотация. В основе действенной социальной политики должно лежать понимание тех стратегий, которые используют российские семьи для адаптации к сложной экономической ситуации в стране. Для этого проводятся регулярные обследования потребительского поведения населения, социологические опросы, позволяющие выявить сберегательные стратегии. Делаются попытки исследовать зарождающееся инвестиционное поведение. Потребительское, сберегательное, инвестиционное поведение населения являются элементами экономического поведения. В связи с этим для повышения эффективности социальной политики наибольшее значение имеют комплексные исследования. Одно из таких исследований представляет проект «Таганрог», который реализуется в течение сорока лет, в ходе которого изучаются различные аспекты жизни домохозяйств этого южного, когда-то промышленного города.

Ключевые слова: экономическое поведение, домашнее хозяйство, сберегательные стратегии, социологические исследования.

\footnotetext{
* Статья подготовлена при поддержке гранта РФФИ № 13-06-00273.
} 
Migranova L.A., Toreyev V.B., Yarasheva A.V.

\title{
Economic behavior: analysis and prospects
}

\begin{abstract}
Efficient social policy should be based on the understanding of strategies which Russian families use for adaptation to a difficult economic situation in the country. This understanding is promoted by regular research into people's consumer behaviour and by sociological surveys of savings strategies. Scientists are studying the investment behaviour of population. Consumer behaviour, savings behaviour and investment behaviour are the elements of economic behaviour of population. The integrated research into these components gives the greatest effect for enhancing the efficiency of social policy. The "Taganrog" Project is one of such integrated studies. This project has been implemented within forty years; its main purpose is to study various aspects of life of households in this southern city that used to be an industrial city.
\end{abstract}

Key words: economic behaviour, household, savings strategy, sociological research.

Migranova Lyudmila Alekseevna - Ph.D. in Economics, Head of the Laboratory for the Study of the Quality of Life of Population, Federal State-Financed Scientific Institution the Institute of Social and Economic Studies of Population, the Russian Academy of Sciences (32, Nakhimov Avenue, Moscow, 117218, Russia, info@isesp-ras.ru,lmigranova@mail.ru)

Toreev Vladimir Borisovich - Doctor of Economics, Head of the Laboratory for the Issues of Economic Behavior and Mobility of Population, Federal State-Financed Scientific Institution the Institute of Social and Economic Studies of Population, the Russian Academy of Sciences (32, Nakhimov Avenue, Moscow, 117218, Russia, info@isesp-ras.ru, v.toreyev@gmail.com)

Yarasheva Aziza Viktorovna - Doctor of Economics, Professor, Chief Research Associate at the Laboratory for the Issues of Economic Behavior and Mobility of Population, Federal State-Financed Scientific Institution the Institute of Social and Economic Studies of Population, the Russian Academy of Sciences (32, Nakhimov Avenue, Moscow, 117218, Russia, info@isesp-ras.ru, nasimy@yandex.ru, baktriana@rambler.ru)

Исследованию экономического поведения населения российская статистика и наука уделяют большое внимание. Так, Росстат регулярно проводит выборочные обследования бюджетов домашних хозяйств в качестве элемента государственного статистического наблюдения за уровнем жизни населения. Проводят регулярные опросы, направленные на оценку материального положения семей и их финансового поведения социологические службы, например ВЦИОМ ${ }^{1}$ и Левадацентр²; анализ потребительских рынков и покупательских предпочтений проводит

\footnotetext{
1 ВЦИОМ [Электронный ресурс]. - Режим доступа: http://wciom.ru

2 Левада-центр [Электронный ресурс]. - Режим доступа: http://www.levada.ru
}

компания «Ромир»³; есть и другие исследовательские центры и компании. Однако комплексного анализа экономического поведения населения в нашей стране не проводилось.

Под экономическим поведением населения будем понимать некий рациональный выбор из возможных альтернатив с целью минимизации издержек и получения максимальной выгоды, используемый населением в качестве механизма адаптации $\mathrm{K}$ изменяющейся внешней среде. Непосредственное влияние на экономическое поведение оказывает принадлежность к определенным социальнодоходным слоям, которые задают уровень

\footnotetext{
3 Исследовательский холдинг РОМИР [Электронный ресурс]. - Режим доступа: http://romir.ru
} 
накопления и потребления для тех или иных групп населения, а также социально-демографические характеристики семьи: иждивенческая нагрузка, количество детей, количество пенсионеров и инвалидов, возраст, состояние здоровья и уровень образования членов семьи.

На экономическое поведение оказывают влияние и социальные группы, в которые входит индивид. В качестве референтных групп могут выступать семья, коллеги по работе, соседи и др. Однако группа принадлежности и референтная группа могут не совпадать и оказывать разнонаправленное воздействие на индивидуума. Референтные группы формируют нормы и ценности, детерминирующие перспективу мышления и поведения человека. В этом плане особое внимание необходимо уделить влиянию семьи, уклада домашней жизни. Семья обладает наиболее сильными адаптационными возможностями в экономически сложных ситуациях.

Наиболее близко к комплексному анализу экономического поведения населения подошли исследования, проводимые в рамках проекта «Таганрог», осуществляемого под научным руководством членакорреспондента РАН Н.М. Римашевской. Цель исследования «состояла в том, чтобы выявить сущность происходящих в России перемен через призму условий жизни, состояния и поведения населения, раскрыть их характер, специфику, факторы и динамику». Фундаментальная проблема, на решение которой был направлен проект, состоит «в обнаружении сущностных изменений в воспроизводстве и качестве жизни населения страны в условиях перехода к рыночной экономике, в рассмотрении механизмов, определяющих социальные процессы, а также, если говорить о практическом использовании полученных результатов, - в разработке мер и предложений по формированию социальной политики» $[1$, с. 10]. Реализовано пять этапов проекта: «Таганрог I» (19681969 гг.), «Таганрог II» (1978-1979 гг.), «Таганрог III» (1988-1989 гг.). Первые три этапа проводились с интервалом в десять лет. Через 5 лет после третьего этапа было осуществлено исследование «Таганрог $3^{1} / 2^{\text {». }}$ Соответственно, четвертый этап получил половинный индекс. Наконец, пятый этап «Таганрог V» был реализован в 19982000 гг.

Первые три этапа были реализованы еще при плановой экономике, при которой экономическое поведение сводилось к потребительскому поведению, т.е. к распределению доходов (в основном заработной платы). Сберегательные стратегии в то время сводились к возможностям, предоставлявшимся Сбербанком (сберкассами), т.е. к получению процентов на остаток счета. Экономическая реформа открыла в этом плане новые возможности. Однако понадобилось двадцать лет, чтобы у населения появились накопления, которые нужно сохранять, преумножать и вкладывать в различные проекты, т.е. осуществлять сберегательное и инвестиционное поведение.

Потребительское поведение домохозяйств с разным социально-экономическим положением являлось предметом детального изучения практически на всех этапах таганрогских исследований. Основной чертой потребительского рынка в дореформенный период была несбалансированность спроса и предложения товаров и услуг, которая с годами все увеличивалась. Однако дефицит продовольственных и промышленных товаров не означал, что жители города Таганрога голодали. Почти четверть городских семей дефицит продуктов питания частично компенсировала их производством на приусадебных и дачных участках. Непродовольственные товары приобретались, но по спекулятивным ценам. Рынок платных услуг был развит слабо и ограничивался в основном 
бытовыми услугами (парикмахерские, бани, химчистки, учреждения общественного питания и т.д.). Социально значимые услуги (медицинские, образовательные, культурные, рекреационные, жилищнокоммунальные) предоставлялись государством бесплатно или за чисто символическую плату, что обеспечивало их равную доступность для всех горожан, независимо от материального положения.

Опросы населения, проведенные в Таганроге в период перехода к рыночным отношениям (1993-1994 гг.) и в более поздние годы (1998-2000 гг.), показали существенные изменения в потребительском поведении горожан, о чем свидетельствуют изменения в структуре потребительских расходов - увеличение доли питания (индикатор снижения уровня жизни) и платных услуг. При этом доля домохозяйств, имеющих личное подсобное хозяйство и производящих сельскохозяйственную продукцию, выросла в начале 1990-х годов почти до 40\%. Несмотря на то что в этот период государство еще сохраняло контроль за тарифами на жилищно-коммунальные услуги, расходы на их оплату росли достаточно быстро как за счёт более высоких темпов роста цен на услуги по сравнению с товарами, так и в результате того, что бесплатные услуги все чаще становились для населения платными. В 1998 г. почти половина $(48,1 \%)$ семей Таганрога ограничивала себя в покупке продуктов питания, а на их приобретение приходилось более $60 \%$ от всех расходов. При этом никакого товарного дефицита уже не было - просто у населения не хватало денег для удовлетворения элементарных потребностей.

Типологическое исследование, проведенное в рамках проекта «Таганрог II» (1978 г.) в условиях низкой дифференциации доходов населения, позволило выявить восемь типов семей с разным потре- бительским поведением. В этих семьях в зависимости от социально-демографических показателей и специфики условий жизни структуры потребностей, потребления и ориентаций населения оказались весьма различными [2].

Спустя 20 лет для типологического исследования использовалась несколько другая модель, которая позволила выделить четыре устойчивые группы потребителей, несмотря на возросшее неравенство в доходах, отсутствие товарного дефицита и расширение рынка платных услуг.

Первая группа представляет собой тип потребления, характерный для низкодоходных домохозяйств Таганрога, душевой доход которых не превышал величины прожиточного минимума (ПМ) по Ростовской области. В основном это полные семьи с одним или двумя детьми. Их тип потребления можно назвать «экстремальным» или «потреблением выживания». Ко второй группе потребителей исследователи отнесли среднедоходные домохозяйства, доход которых оказался выше прожиточного минимума, но ниже величины 2,5 ПМ. Это полные семьи малого размера, преимущественно без детей либо с одним ребенком. От первого типа потребительский стиль этих домохозяйств отличается более высокими характеристиками потребления, более разнообразной и рациональной структурой потребления как продуктов питания, так и непродовольственных товаров и услуг. Третья группа - наиболее состоятельные домохозяйства с доходами выше 2,5-кратного размера ПМ. В основном это полные семьи без детей (только треть составляют семьи с одним ребенком), расположенные в границах средних и высоких социальных статусов. Для представителей этой группы характерен иной количественный и качественный уровень потребления. Однако в целом их потребительское поведение 
можно назвать «консервативно-потребительским» из-за ориентации на сохранение и поддержание сложившегося в прошлом потребительского уклада. Четвертая группа потребителей - домохозяйства пенсионеров. Из-за отсутствия иждивенческой нагрузки в этих домохозяйствах, несмотря на низкий размер пенсий, благоприятное материальное положение (по сравнению с пенсионерами, проживающими вместе с родственниками). Данная группа занимает промежуточное положение между первой и второй, однако имеет и свои специфические особенности. В первую очередь это касается приобретения продуктов питания и лекарственных средств. Потребители этой группы вынуждены рассчитывать только на свои материальные возможности, в связи с чем редко занимают денежные средства в долг. Исследователи назвали четвертую группу «аскетической», исходя из наблюдаемой максимально жесткой экономии.

Дальнейшее изменение социальной структуры населения города под влиянием кардинально не меняющейся на локальном рынке труда ситуации, безусловно, изменило распределение населения по типам потребительского поведения, но само количество типов вряд ли стало больше. Таганрог уже в конце 1980-х - начале 1990-х годов по уровню оплаты труда и денежных доходов населения стал резко отставать как от среднероссийского, так и среднеобластного уровня, тогда как масштабы бедности и малообеспеченности домохозяйств росли более быстрыми темпами [3].

По данным Росстата, объем реального потребления платных услуг на душу населения в Ростовской области за последние 11 лет вырос в 1,55 раза против 1,47 раза по РФ в целом; реальный душевой объем розничного товарооборота в области также увеличивался более высокими темпами и составил 2,8 раза. Однако оба эти показателя оставались ниже среднего по стране уровня (73 и 95\% соответственно). Но Таганрог - не Ростовская область, где большая часть розничного товарооборота и платных услуг реализуется непосредственно в Ростове-на-Дону. В связи с этим можно предположить, что потребление товаров и услуг в Таганроге, по всей видимости, за этот период выросло, но в значительно меньшей степени, чем по области в целом, и разрыв со среднероссийскими показателями несколько увеличился.

Социологические опросы дают возможность выяснить материальное положение российских семей с позиции самооценки. Рассматривая динамику материального положения на достаточно длительном периоде, можно отметить, что количество семей, оценивающих его положительно, постепенно растет (табл. 1). Если количество семей, не имеющих материальных затруднений, остается на протяжении всего периода наблюдений неизменным порядка $1 \%$, то количество семей, ограниченных в приобретении только дорогих вещей, постоянно растет (с 7\% в 2001 году до $16 \%$ в 2010 г.). Нужно отметить, что и в низкодоходных группах происходит постепенное улучшение положения. Так, количество беднейших семей сократилось с 22 до 9\%, а в других группах произошло перераспределение: если в 2001 году группа семей, которой хватало денег только на продукты, составляла 44\%, то в 2010 году она сократилась до 27\%, а группа семей, где денег не хватало только на товары длительного пользования, наоборот, увеличилась с 27 до $48 \%$.

Растущее материальное положение создает условия для формирования сбережений. В таблице 2 представлена динамика сберегательных возможностей российских семей. 
Таблица 1. К какой группе населения Вы, скорее всего, отнесли бы свою семью?* (\% от числа ответивших)

\begin{tabular}{|c|c|c|c|c|c|c|c|}
\hline Вариант ответа & 11.2001 & 11.2003 & 11.2005 & 11.2007 & 06.2008 & 10.2009 & 08.2010 \\
\hline Денег не хватает даже на продукты & 22 & 15 & 15 & 14 & 12 & 13 & 9 \\
\hline $\begin{array}{l}\text { Ha продукты денег хватает, } \\
\text { но покупка одежды вызывает } \\
\text { серьезные затруднения }\end{array}$ & 44 & 45 & 37 & 33 & 29 & 29 & 27 \\
\hline $\begin{array}{l}\text { Денег хватает на продукты и } \\
\text { одежду, но покупка товаров } \\
\text { длительного пользования является } \\
\text { для нас проблемой }\end{array}$ & 27 & 31 & 37 & 37 & 42 & 47 & 48 \\
\hline $\begin{array}{l}\text { Мы можем без труда приобретать } \\
\text { вещи длительного пользования, } \\
\text { но затруднительно приобретать } \\
\text { действительно дорогие вещи }\end{array}$ & 7 & 9 & 10 & 15 & 17 & 12 & 16 \\
\hline $\begin{array}{l}\text { Мы можем позволить себе } \\
\text { достаточно дорогие покупки - } \\
\text { машину, квартиру, дачу и многое } \\
\text { другое }\end{array}$ & $<1$ & 1 & $<1$ & 1 & 1 & 1 & 1 \\
\hline
\end{tabular}

Таблица 2. Есть ли у Вас, Вашей семьи в настоящее время какие-либо сбережения, накопления? (\% от числа ответивших)

\begin{tabular}{|l|c|c|c|c|c|c|c|}
\hline \multicolumn{1}{|c|}{ Вариант ответа } & 07.2002 & 07.2003 & 07.2005 & 07.2007 & 12.2008 & 10.2009 & 10.2010 \\
\hline Есть & 26 & 24 & 21 & 22 & 18 & 22 & 26 \\
\hline Нет & 68 & 69 & 70 & 66 & 75 & 73 & 69 \\
\hline Не знаю/отказ от ответа & 6 & 7 & 9 & 13 & 7 & 5 & 5 \\
\hline
\end{tabular}

Из таблицы видно, что экономический кризис 2008 года сильно повлиял на уровень сбережений населения, однако к 2010 году ситуация вернулась к благополучным докризисным временам. Так или иначе, можно утверждать, что порядка четверти населения России имеют сбережения, т.е. могут осуществлять не только потребительское, но и сберегательное и инвестиционное поведение.

В процессе становления рыночных отношений в российской экономике сложились два базовых типа экономического поведения населения: дорыночный и рыночный. Для носителей дорыночного типа поведения характерно неприятие рынка или настороженное отношение к нему, низкая оценка собственных возможностей адаптации к рыночной экономике, высокий уровень социальной и психоло- гической напряженности личности, находящейся под сильным влиянием социальных стереотипов, выработанных еще в советские годы. Рыночный тип поведения предполагает высокую степень экономической активности со стороны индивида, понимание возможностей, которые рынок предоставляет для повышения благосостояния соответственно вложенным усилиям, знаниям, умениям.

При этом используются разные сберегательные стратегии. Если люди дорыночного типа экономического поведения предпочитают хранить сбережения или в наличных (что называется «в кубышке»), или в сбербанке, то приверженцы рыночного типа поведения используют более разнообразные стратегии: вложение в акции, облигации, инвестирование в бизнес, покупка недвижимости и др. 
Таблица 3. Как Вы храните сбережения? (\% от числа ответивших)

\begin{tabular}{|c|c|c|c|c|c|}
\hline Вариант ответа & 09.2002 & 09.2005 & 09.2007 & 10.2009 & 10.2010 \\
\hline В Сберегательном банке & 41 & 44 & 50 & 53 & 58 \\
\hline В коммерческом банке & 4 & 5 & 6 & 6 & 9 \\
\hline $\begin{array}{l}\text { В облигациях государственных займов, других ценных государ- } \\
\text { ственных бумагах }\end{array}$ & 2 & 2 & 2 & 1 & 1 \\
\hline В накопительных страховых полисах & 1 & 1 & 1 & 1 & 1 \\
\hline $\begin{array}{l}\text { В акциях и других ценных бумагах акционерных обществ, инвести- } \\
\text { ционных фондов, банков и т.д. }\end{array}$ & 3 & 5 & 5 & 3 & 3 \\
\hline В наличных деньгах & 20 & 24 & 29 & * & * \\
\hline В <твердой> валюте & 40 & 24 & 16 & * & * \\
\hline В наличных рублях & * & * & * & 29 & 29 \\
\hline В наличных долларах & * & * & * & 8 & 8 \\
\hline В наличных евро & * & * & * & 17 & 10 \\
\hline В изделиях из драгоценных металлов, антиквариате, картинах & 8 & 6 & 6 & 8 & 5 \\
\hline Другим образом & 2 & 2 & 2 & 3 & 1 \\
\hline Затруднились ответить & 17 & 20 & 20 & 16 & 16 \\
\hline
\end{tabular}

В таблице 3 представлены сберегательные стратегии населения. Как видно, наиболее надежным инструментом сохранения денежных средств население считает Сберегательный банк, несмотря на огромные потери сбережений от инфляции после экономической реформы 1992 года и отсутствие начисления процентов на остаток вклада, как было в советское время 4 . За десять лет доля населения, избравшая Сбербанк как форму хранения сбережений, выросла на 17\%. Более половины опрошенных предпочитают хранить сбережения в Сбербанке. Имидж государственного банка, сформировавшийся еще в советское время и поддерживаемый в послереформенные времена, дает возможность населению считать его наиболее надежной формой хранения денег.

Следующей по популярности формой хранения сбережений являются наличные деньги. Скандалы, связанные с американской экономикой, и слухи о девальвации американского доллара подорвали доверие российского населения к этой популярной в 1990-е годы валюте. Люди предпочитают хранить наличные рубли или

4 Проценты на остатки в Сберегательном банке РФ начисляются только для пенсионных вкладов. европейскую валюту (евро). Таким образом, у российского населения преобладают формы хранения сбережений, характерные для дорыночного типа экономического поведения.

Совсем немного опрошенных используют современные и зачастую более доходные способы хранения (ценные бумаги, акции, облигации и др.). Это можно объяснить тем, что в России пока слабо развит рынок ценных бумаг и практически отсутствует общедоступная информация о возможностях его использования. Особенно сложно использовать эти сберегательные технологии живущим на периферии, вдали от крупных городов. Даже образованные молодые люди, хорошо адаптированные к условиям рыночной экономики, зачастую вынуждены использовать более доступные формы хранения сбережений, такие как вклады в Сбербанк и наличные, что присуще старшему поколению с дорыночным типом экономического поведения.

Важным представляется выяснить цели, которые преследуют люди, делая накопления. В таблице 4 приведены ответы респондентов о целях формирования сбережений. 
Таблица 4. Для каких целей Вы сейчас делаете сбережения или стали бы делать, если бы у Вас была возможность? (\% от числа ответивших)

\begin{tabular}{|l|c|c|c|c|c|}
\hline \multicolumn{1}{|c|}{ Вариант ответа } & 09.2002 & 09.2005 & 09.2007 & 10.2009 & 10.2010 \\
\hline Покупка дорогих вещей & 14 & 13 & 11 & 11 & 13 \\
\hline Покупка квартиры, собственного дома & 20 & 21 & 21 & 22 & 22 \\
\hline Образование & 22 & 20 & 19 & 18 & 14 \\
\hline Лечение & 27 & 24 & 19 & 24 & 26 \\
\hline Отдых, развлечения, путешествия & 12 & 13 & 12 & 19 & 21 \\
\hline Собственное дело, покупка акций & 4 & 4 & 4 & 6 & 5 \\
\hline Покупка земли, дачи, садового домика & 3 & 3 & 2 & 6 & 6 \\
\hline Покупка автомобиля & 9 & 10 & 10 & 13 & 14 \\
\hline На всякий случай, про запас & 35 & 36 & 33 & 41 & 42 \\
\hline Другие цели & 6 & 5 & 7 & 4 & 6 \\
\hline Не стал бы делать сбережения ни на какие цели & 9 & 7 & 10 & 11 & 11 \\
\hline Затруднились ответить & 8 & 9 & 10 & 5 & 6 \\
\hline
\end{tabular}

Наиболее часто декларируемой причиной стала неуверенность в завтрашнем дне (ответ «на всякий случай, про запас»), желание обеспечить возможность выжить в очередной кризисной ситуации. Череда экономических потрясений в 1990-е и кризис 2008-2009 годов приучили население к мысли, что с нашей экономикой в любой момент может случиться нечто нехорошее, к чему нужно быть готовым.

Следующая по количеству ответов цель сбережений также относится к обеспечению нормальной жизни в перспективе - лечение. Переход от полностью бесплатной к частично бесплатной медицине породил необходимость иметь средства на случай серьезного заболевания. Необходимо отметить и старение российского населения, а вместе с возрастом приходят и заболевания.

Приобретение дома или квартиры для большинства российских семей возможно только после накопления определенной суммы. Даже при использовании ипотечного кредита необходимо внести первоначальный взнос, который может достигать $30 \%$ стоимости квартиры.

Уменьшение расходов на образование может свидетельствовать, во-первых, об общем старении населения, соответственно, о сокращении количества молодых людей, которым необходимо обра- зование; во-вторых, о разочаровании в образовании как социальном «лифте», позволяющем сделать карьеру. Почти в два раза увеличилось количество семей, откладывающих средства на отдых и путешествия.

Рассмотрение только нескольких составляющих экономического поведения населения демонстрирует сильную связь, существующую между составом семьи, образом жизни и уровнем заработной платы, потребительским и сберегательным поведением. Каждый член семьи, представляющий собой потенциального потребителя, имеет свои психологические особенности, тип характера и темперамент и, в соответствии с этим, собственную потребительскую мотивацию, которую необходимо учитывать, потому что она является движущей силой, активирующей поведение и определяющей цель и направление этой активности. В связи с этим можно подчеркнуть, что только комплексные исследования могут дать полную картину экономического поведения населения.

Прошло 13 лет после проведения последнего социально-экономического обследования населения в Таганроге. Российская экономика не только полностью перешла к рыночным отношениям, но и стала частью глобального мира. 
Иллюзия первых лет в отношении того, что рынок решит если не все, то большинство наших проблем, исчезла даже у руководства страны. Экономические и финансовые кризисы сменяют друг друга со все возрастающей периодичностью и затрагивают все слои населения. Поэтому одна из целей нового обследования населения в Таганроге, которое будет предпринято учеными ИСЭПН РАН, - выявить динамику в экономическом поведении, оценить риски недопотребления для домохозяйств с невысоким социально-экономическим положением в средних по численности населения городах с некогда развитой промышленностью.

Подводя итог, можно констатировать, что поведение потребителя - экономически сложный процесс обобщения и анализа потенциальных потребностей и привычек, которые, так или иначе, формируют величину спроса и оказывают значительное влияние на структуру предложения на потребительском рынке. Актуальной научной проблемой остается выяснение механизмов влияния современных социальных факторов повседневной жизни человека на его потребительскую активность.
Глубокая дифференциация в показателях уровня жизни населения России в региональном разрезе вносит свои существенные коррективы в формирование модели экономического поведения, особенно сберегательного и инвестиционного. Для домашних хозяйств на первый план выдвигается задача обеспечения экономических условий и организации воспроизводства человеческого потенциала членов семьи.

Потребность населения нашей страны в цивилизованных формах экономического поведения в значительной мере должна способствовать вложению существенных средств в реальный сектор экономики и, следовательно, устойчивому росту экономического потенциала государства и благосостояния в обществе. Недостаточность серьезных актуальных теоретических и методологических разработок в области экономического поведения может привести к тому, что при планировании и в процессе проведения дальнейших социально-экономических реформ могут оказаться неучтенными социальные ценности и установки, определяющие структуру экономической и финансовой культуры населения.

\section{Литература}

1. Женщина, мужчина, семья в России: последняя треть XX века. Проект «Таганрог» / под ред. Н.М. Римашевской. - М.: Издательство ИСЭПН РАН, 2001.

2. Овсянников, А.А. Типология потребительского поведения / А.А. Овсянников, И.И. Петтай, Н.М. Римашевская. - М.: Наука, 1989.

3. Семейное благосостояние и здоровье. Проект «Таганрог-три с половиной». - Т. 1. - М., 1997.

\section{References}

1. Zhenshchina, muzhchina, sem'ya v Rossii: poslednyaya tret' XX veka. Proekt “Taganrog” [Woman, Man, Family in Russia: the Last Third of the 20th Century. "Taganrog" Project]. Ed. by N.M. Rimashevskaya. Moscow: ISEPN RAN Publ., 2001.

2. Ovsyannikov A.A., Pettay I.I., Rimashevskaya N.M. Tipologiya potrebitel'skogo povedeniya [Typology of Consumer Behaviour]. Moscow: Nauka, 1989.

3. Semeynoe blagosostoyanie i zdorov'e. Proekt "Taganrog-tri s polovinoy" [Family Well-Being and Health. Project "Taganrog Three and a Half”]. Vol. 1. Moscow, 1997. 
УДК 314.15, ББК 60.74

(C) Попова Л.А.

\section{Оценка эффективности государственных демографических инициатив*}

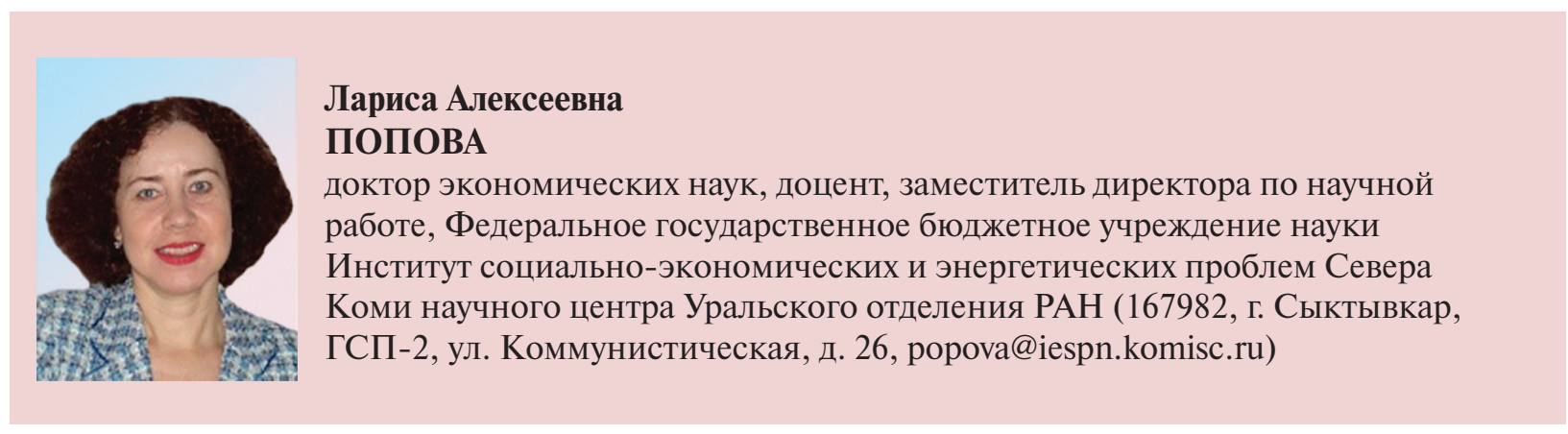

Аннотация. Выявляется влияние на демографические процессы в России федеральных и региональных мер демографической политики 2006-2011 годов, а также национального проекта «Здоровье» и программ модернизации здравоохранения на 2011-2012 годы. Раскрываются современные тенденции рождаемости населения России, изменения в ее структуре по возрасту и брачному состоянию матери. Оценивается, какие реальные поколения получили максимальный репродуктивный выигрыш от пронаталистских мер демографической политики и каковы перспективы рождаемости. Рассматривается динамика продолжительности жизни населения России и изменения в структуре смертности по причинам.

Ключевые слова: Россия, демографическая политика, национальные проекты, здоровье населения, рождаемость, смертность, продолжительность жизни.

Popova L.A.

\section{Evaluation of efficiency of the public demographic initiatives}

Popova Larisa Alekseevna - Doctor of Economics, Associate Professor, Deputy Director for Science, the Institute of Socio-Economic and Energy Problems of the North Komi Scientific Centre, Ural Branch of the Russian Academy of Sciences (26, Kommunisticheskaya Street, Syktyvkar, 167982, Russia, popova@iespn.komisc.ru)

* Работа выполнена в рамках проекта конкурсных программ межрегиональных и межведомственных фундаментальных исследований УрО РАН «Демографическое развитие северных регионов России в условиях социальноэкономической трансформации» (регистрационный номер 12-С-7-1009). 
Abstract. The article reveals how the demographic processes in Russia are influenced by federal and regional demographic policy measures of 2006-2011 and by the national project "Health" and health care modernization programmes for 2011-2012. The author dwells upon the modern trends in the birth rate of Russia's population, upon the changes in its structure by the age and marital status of mother. The article evaluates which actual generations have received the maximum reproductive benefit from pronatalist demographic policies, and what are the prospects concerning fertility. The article considers the dynamics of life expectancy of Russia's population and the changes in the structure of mortality by causes.

Keywords: Russia, demographic policy, national projects, health of the population, fertility, mortality, life expectancy.

В 2010-2011 гг. в России исчерпал свое действие структурный фактор повышения уровня рождаемости: вследствие достижения репродуктивных возрастов малочисленными поколениями 1990-х годов рождения количество женщин основного детородного возраста (до 35 лет) перешло в фазу снижения ${ }^{1}$ В этих условиях поддерживать рождаемость на относительно высоком уровне может только ее интенсивность. Поэтому вопросы, связанные с возможностью воздействия на интенсивность рождаемости, с оценкой последствий государственной демографической политики последних лет и вероятными перспективами рождаемости, представляют значительный интерес.

Как известно, в 2000 г., после 12-летнего периода снижения рождаемости, в течение которого годовое число родившихся сократилось в стране более чем вдвое (с 2500 тыс. в 1987 г. до 1215 тыс. в 1999 г.), в России началось увеличение ее показателей. В 2012 г. родилось 1896,3 тыс. детей ${ }^{2}$, что на 56,1\% больше, чем в 1999 г. Рост рождаемости происходил в убывающем населении, поэтому величина общего

1 Захаров С. Какой будет рождаемость в России // Демоскоп Weekly, №495-496. 23 января - 5 февраля 2012 г. [Электронный ресурc]. - URL: http:// demoscope.ru/ weekly/2012/0495/tema01.php (дата обращения: 20.06.2013).

2 Щербакова Е. Демографические итоги 2012 г. (Часть I) // Демоскоп Weekly, №541-542. 4-17 февраля 2013 г. [Электронный ресурс]. - URL: http://demoscope.ru/ weekly/2013/0541/barom03.php (дата обращения: 20.06.2013) коэффициента увеличилась за это время еще существеннее: на $60,2 \%$ (с 8,3 рождения на 1000 человек населения в 1999 г. до 13,3 - в 2012 г.).

Повышение рождаемости во многом было обусловлено структурным фактором: вплоть до конца прошлого десятилетия в России происходило улучшение возрастной структуры репродуктивных контингентов, поскольку активных детородных возрастов достигали относительно многочисленные поколения начала-середины 1980 -х годов рождения. Однако интенсивность рождаемости также достаточно заметно возросла, о чем свидетельствует динамика суммарного коэффициента рождаемости (табл. 1), который увеличился с 1,16 детей в 1999 г. до 1,58 - в 2011 г. (на 36,2\%).

В первые годы рост определялся реализацией в условиях экономической стабилизации ранее отложенных населением рождений, что хорошо видно по динамике повозрастных коэффициентов рождаемости. В 2000 г. увеличение показателей наблюдалось исключительно в возрастных группах от 25 до 44 лет (табл. 1 u 2). И далее, вплоть до 2004 г., именно эти возраста вносили основной вклад в повышение общего уровня рождаемости.

К сожалению, этот вывод невозможно подкрепить динамикой структуры рождаемости по очередности рождения, поскольку по Федеральному закону 
Таблица 1. Возрастные коэфффициенты рождаемости в Российской Федерации в 2000-2011 гг.

\begin{tabular}{|c|c|c|c|c|c|c|c|c|c|}
\hline \multirow{2}{*}{ Год } & \multicolumn{8}{|c|}{ Родившиеся в среднем за год на 1000 женщин в возрасте, лет } & \multirow{2}{*}{$\begin{array}{c}\text { Суммарный } \\
\text { коэфффициент } \\
\text { рождаемости }\end{array}$} \\
\hline & $15-19$ & $20-24$ & $25-29$ & $30-34$ & $35-39$ & $40-44$ & $45-49$ & $15-49$ & \\
\hline 2000 & 27,4 & 93,6 & 67,3 & 35,2 & 11,8 & 2,4 & 0,1 & 32,1 & 1,195 \\
\hline 2001 & 27,3 & 93,1 & 70,2 & 38,0 & 12,9 & 2,4 & 0,1 & 33,1 & 1,223 \\
\hline 2002 & 27,4 & 95,7 & 75,1 & 41,7 & 14,7 & 2,6 & 0,1 & 35,2 & 1,286 \\
\hline 2003 & 27,6 & 95,3 & 78,3 & 44,0 & 16,0 & 2,7 & 0,1 & 36,5 & 1,320 \\
\hline 2004 & 28,2 & 94,2 & 80,1 & 45,8 & 17,6 & 2,9 & 0,1 & 37,7 & 1,344 \\
\hline 2005 & 27,4 & 88,4 & 77,8 & 45,3 & 17,8 & 3,0 & 0,2 & 36,9 & 1,294 \\
\hline 2006 & 28,2 & 87,8 & 78,4 & 46,6 & 18,6 & 3,1 & 0,1 & 37,7 & 1,305 \\
\hline 2007 & 28,3 & 89,5 & 86,9 & 54,1 & 22,7 & 3,9 & 0,2 & 41,4 & 1,416 \\
\hline 2008 & 29,3 & 91,2 & 92,4 & 60,0 & 25,8 & 4,6 & 0,2 & 44,6 & 1,502 \\
\hline 2009 & 28,7 & 90,5 & 95,9 & 63,6 & 27,6 & 5,2 & 0,2 & 46,4 & 1,542 \\
\hline 2010 & 27,0 & 87,5 & 99,2 & 67,3 & 30,0 & 5,9 & 0,3 & 47,8 & 1,567 \\
\hline 2011 & 26,7 & 87,5 & 99,8 & 68,2 & 31,4 & 6,3 & 0,3 & 48,8 & 1,582 \\
\hline
\end{tabular}

Таблица 2. Темпы прироста показателей рождаемости в Российской Федерации в 2000-2011 гг., \%*

\begin{tabular}{|c|c|c|c|c|c|c|c|c|c|}
\hline \multirow{2}{*}{ Период } & \multicolumn{8}{|c|}{ Родившиеся в среднем за год на 1000 женщин в возрасте, лет } & \multirow{2}{*}{$\begin{array}{c}\text { Суммарный } \\
\text { коэффрициент } \\
\text { рождаемости }\end{array}$} \\
\hline & $15-19$ & $20-24$ & $25-29$ & $30-34$ & $35-39$ & $40-44$ & $45-49$ & $15-49$ & \\
\hline $2000-2001$ & $-0,4$ & $-0,5$ & 4,3 & 8,0 & 9,3 & 0,0 & 0,0 & 3,1 & 2,3 \\
\hline $2001-2002$ & 0,4 & 2,8 & 7,0 & 9,7 & 14,0 & 8,3 & 0,0 & 6,3 & 5,2 \\
\hline 2002-2003 & 0,7 & $-0,4$ & 4,3 & 5,5 & 8,8 & 3,8 & 0,0 & 3,7 & 2,6 \\
\hline 2003-2004 & 2,2 & $-1,2$ & 2,3 & 4,1 & 10,0 & 7,4 & 0,0 & 3,3 & 1,8 \\
\hline 2004-2005 & $-2,8$ & $-6,2$ & $-2,9$ & $-1,1$ & 1,1 & 3,4 & 100,0 & $-2,1$ & $-3,7$ \\
\hline 2005-2006 & 2,9 & $-0,7$ & 0,8 & 2,9 & 4,5 & 3,3 & $-50,0$ & 2,2 & 0,9 \\
\hline 2006-2007 & 0,4 & 1,9 & 10,8 & 16,1 & 22,0 & 25,8 & 100,0 & 9,8 & 8,5 \\
\hline $2007-2008$ & 3,5 & 1,9 & 6,3 & 10,9 & 13,7 & 17,9 & 0,0 & 7,7 & 6,1 \\
\hline 2008-2009 & $-2,0$ & $-0,8$ & 3,8 & 6,0 & 7,0 & 13,0 & 0,0 & 4,0 & 2,7 \\
\hline 2009-2010 & $-5,9$ & $-3,3$ & 3,4 & 5,8 & 8,7 & 13,5 & 50,0 & 3,0 & 1,6 \\
\hline 2010-2011 & $-1,1$ & 0,0 & 0,6 & 1,3 & 4,7 & 6,8 & 0,0 & 2,1 & 1,0 \\
\hline Всего за 2000-2011 & $-2,6$ & $-6,5$ & 48,3 & 93,8 & 166,1 & 162,5 & 200,0 & 52,0 & 32,4 \\
\hline
\end{tabular}

№143-Ф3 «Об актах гражданского состояния» от 15 ноября 1997 года ${ }^{3}$ с 1999 г. информация об очередности рождения была исключена из Записей актов о рождении. В первой половине 2000-х годов даже в тех субъектах Российской Федерации, где такая статистика продолжала разраба-

3 Об актах гражданского состояния: Федеральный закон №143 от 15 ноября 1997 г. // Российская газета. 1997. - №224. - 20 ноября. тываться на основе медицинских свидетельств о рождении (порядка 60 регионов из 80), доля рождений с неуказанной очередностью была очень велика. Например, в Республике Коми в 1999 г. очередность рождения не была указана в $4,3 \%$ случаев, а в 2000 г. эта цифра достигла 52,4\%. В 2001 г. в статистику не попал порядок рождения в 17,6\% случаях, в 2002 г. в $16,5 \%$, в 2004 г. - в $6,6 \%$. 
В 2005 г. в стране произошло снижение рождаемости. Хотя, подчеркнем, структурный фактор в это время еще весьма активно содействовал увеличению ее уровня. Очевидно, этап спонтанной реализации отложенных рождений, для которой не потребовалось никаких стимулирующих мер, к этому времени практически подошел к концу. В указанном году повышение показателей наблюдалось лишь в самых старших группах фертильного возраста: по всей видимости, состоялись запланированные рождения высокой очередности у представителей поколений 1956-1970 годов рождения, которые в начале десятилетия реализовали отложенные предыдущие рождения.

В этих условиях выделение в Федеральном послании 2006 г. демографической проблемы в качестве самой острой, ключевой проблемы современной России следует признать чрезвычайно своевременным. Перед законодательными и исполнительными органами власти была поставлена задача по развертыванию активной демографической политики в области стимулирования рождаемости с заданием приступить к ее реализации не позднее 1 января 2007 г. Результатом выполнения «Сводного плана мероприятий по реализации основных положений Послания Президента Российской Федерации Федеральному Собранию Российской Федерации 2006 года» явилось принятие в ноябре-декабре 2006 г. ряда федеральных законов («О внесении изменений в отдельные законодательные акты Российской Федерации в части государственной поддержки граждан, имеющих детей» от 5 декабря 2006 г. №207-Ф34,

4 О внесении изменений в отдельные законодательные акты Российской Федерации в части государственной поддержки граждан, имеющих детей: Федеральный закон от 5 декабря 2006 г. №207 // Российская газета. - 2006. - №279. - 12 дек.
«Об обеспечении пособиями по временной нетрудоспособности, по беременности и родам граждан, подлежащих обязательному социальному страхованию» от 29 декабря 2006 г. №255-Ф35, «О дополнительных мерах государственной поддержки семей, имеющих детей» от 29 декабря 2006 г. №256-Ф36 рому с 1 января 2007 г. был введен государственный сертификат на материнский (семейный) капитал), а также разработка «Концепции демографической политики Российской Федерации на период до 2025 года», утвержденной Указом Президента от 9 октября 2007 года ${ }^{7}$ № 1351.

Особо при этом следует отметить провозглашенный вновь после длительного перерыва дифференцированный подход к стимулированию рождений разной очередности. В качестве приоритета был выдвинут второй ребенок - именно тот, кто зачастую является очень желанным (согласно ежегодным репрезентативным обследованиям ВЦИОМ, даже в 1990-х годах, за исключением 1992-го и 1994-го, уровни среднего желаемого и среднего идеального числа детей в семье были выше двух $\left.{ }^{8}\right)$, но для рождения которого сушествует слишком много ограничений в семьях, сознательно планирующих свою жизнь.

5 Об обеспечении пособиями по временной нетрудоспособности, по беременности и родам граждан, подлежащих обязательному социальному страхованию: Федеральный закон от 29 декабря 2006 г. №255 // Там же.

6 О дополнительных мерах государственной поддержки семей, имеющих детей: Федеральный закон №256 // Там же.

7 Об утверждении Концепции демографической политики Российской Федерации на период до 2025 года: Указ Президента Российской Федерации от 09.10.2007 г. №1351 [Электронный ресурс]. - URL: http:// document.kremlin.ru/doc.asp?ID=041941 (дата обращения: 20.06.2013).

8 Бодрова В. Сколько детей хотят иметь россияне? // Демоскоп Weekly, №81-82. 23 сентября - 6 октября 2002 г. [Электронный ресурс]. - URL: http:// demoscope.ru/ weekly/2002/081/tema01.php (дата обращения: 20.06.2013). 
Федеральное послание сыграло определенную роль чисто на психологическом уровне еще до введения в действие новых мер демографической политики, поскольку в нем был провозглашен официальный государственный курс, последовательно продолжавший новую социальную политику государства, получившую выражение в приоритетных национальных проектах, стартовавших с начала года. Уже в 2006 г. в большинстве возрастных групп (за исключением возрастов 20-24 и 45-49 лет) произошло некоторое повышение интенсивности рождаемости, определившее в указанном году рост суммарного коэффициента в целом.

В 2007-2008 гг., когда возрастание суммарного коэффициента рождаемости оказалось максимальным (на 8,5 и 6,1\% соответственно), увеличение интенсивности рождаемости наблюдалось во всех без исключения возрастных группах - с нарастанием темпов прироста к старшим возрастам. В результате возрастная мода рождаемости в 2008 г. переместилась из группы 20-24 лет в группу 25-29 лет. Однако самый значительный прирост произошел в возрастах старше 35 лет. Очевидно, что в это время состоялись отложенные рождения, для реализации которых был нужен определенный толчок, т.е. те рождения, которых без мер демографической политики не было бы.
Переход от повозрастных коэффициентов для условных поколений к реальным когортам женщин, для которых эти коэффициенты характерны в тот или иной год наблюдения, показывает, какие поколения получили максимальный «репродуктивный выигрыш» от новых демографических инициатив государства (табл. 3). Более всего они содействовали реализации итоговой плодовитости поколений 1963-1973 годов рождения: в 2007-2008 гг. повозрастная интенсивность рождаемости этих поколений возросла на 14-26\%. Поколения 1973-1983 годов рождения также получили значительный импульс для реализации своих репродуктивных планов: увеличение интенсивности рождаемости составило у них 6-16\%. Кроме того, меры стимулирования рождаемости в первые два года после их введения отчасти способствовали более раннему началу реализации фертильности когортами 1983-1993 годов рождения.

Уже в 2009-2011 гг. темпы прироста показателей рождаемости заметно снизились. А в группах до 24 лет вновь началось сокращение возрастных коэффициентов. Необходимо отметить, что для двух самых молодых возрастных групп 2000-е годы в целом характеризуются понижением интенсивности рождаемости. В то же время в группе 30-34 лет за 2000-2011 гг. практически произошло

Таблица 3. Реальные поколения, обеспечившие рост суммарного коэфффициента рождаемости в 2007-2011 гг., годы рождения (темп прироста, \%)

\begin{tabular}{|c|c|c|c|c|c|c|}
\hline \multirow{2}{*}{ Год } & \multicolumn{6}{|c|}{ Возрастные группы, лет } \\
\cline { 2 - 7 } & $15-19$ & $20-24$ & $25-29$ & $30-34$ & $35-39$ & $40-44$ \\
\hline \multirow{2}{*}{2007} & $1988-1992$ & $1983-1987$ & $1978-1982$ & $1973-1977$ & $1968-1972$ & $1963-1967$ \\
& $(0,4 \%)$ & $(1,9 \%)$ & $(10,8 \%)$ & $(16,1 \%)$ & $(22,0 \%)$ & $(25,8 \%)$ \\
\hline \multirow{2}{*}{2008} & $1989-1993$ & $1984-1988$ & $1979-1983$ & $1974-1978$ & $1969-1973$ & $1964-1968$ \\
& $(3,5 \%)$ & $(1,9 \%)$ & $(6,3 \%)$ & $(10,9 \%)$ & $(13,7 \%)$ & $(17,9 \%)$ \\
\hline \multirow{2}{*}{2009} & & & $1980-1984$ & $1975-1979$ & $1970-1974$ & $1965-1969$ \\
& & & $(3,8 \%)$ & $(6,0 \%)$ & $(7,0 \%)$ & $(13,0 \%)$ \\
\hline \multirow{2}{*}{2010} & & & $1981-1985$ & $1976-1980$ & $1971-1975$ & $1966-1970$ \\
& & & $(3,4 \%)$ & $(5,8 \%)$ & $(8,7 \%)$ & $(13,5 \%)$ \\
\hline \multirow{2}{*}{2011} & & & $1982-1986$ & $1977-1981$ & $1972-1976$ & $1967-1971$ \\
& & & $(0,6 \%)$ & $(1,3 \%)$ & $(4,7 \%)$ & $(6,8 \%)$ \\
\hline
\end{tabular}


удвоение возрастного коэффициента рождаемости, в группах 35-39 и 40-44 лет показатель рождаемости увеличился в 2,6 раза. Иными словами, в минувшее десятилетие произошел серьезный сдвиг в возрастной модели рождаемости российского населения. Сдвиг, на наш взгляд, весьма позитивный, свидетельствующий об усилении сознательной компоненты рождаемости.

В 2009-2011 гг. максимальное повышение интенсивности рождаемости характерно для реальных поколений 1966-1980 годов рождения. Поколения 1981-1986 годов рождения также внесли в эти годы вклад в повышение суммарного коэффициента рождаемости. Т.е. демографические инициативы 2006-2007 гг. сыграли позитивную стимулирующую роль для всех старших поколений женщин - до середины 1980-х годов рождения включительно. В то же время поколения $1987-$ 1996 годов рождения серьезного стимулирующего воздействия демографической политики на интенсивность рождаемости уже не ощутили.

Государственные демографические инициативы 2006-2007 гг. содействовали не только более полной реализации существовавших репродуктивных планов старших поколений, откладывавшихся год за годом, но и способствовали повышению уровня репродуктивных ожиданий населения. Согласно выборочному обследованию «Семья и рождаемость» ${ }^{9}$, проведенному Росстатом в сентябре-октябре 2009 г. в 30 субъектах федерации, среднее ожидаемое число детей у женщин составляет 1,72 , у мужчин - 1,90 , среднее желаемое число детей у женщин - 2,28,

\footnotetext{
9 Краткие итоги выборочного обследования «Семья и рождаемость» [Электронный ресурс]. - URL: http:// www.gks.ru/free doc/2010/family.htm (дата обрашения: 20.06.2013)
}

у мужчин - 2,38, что заметно выше репродуктивных ожиданий россиян, выявленных в обследованиях ВЦИОМ в 19912000 годах ${ }^{10}$.

В качестве бесспорного позитивного результата демографической политики 2006-2007 гг. следует оценить и повышение в России семейной рождаемости, т.е. удельного веса рождений в официально регламентированных семьях. После двух с лишним десятилетий роста уровень внебрачной рождаемости снизился в стране с $30 \%$ в 2005 г. до $24,6 \%$ в 2011 году ${ }^{11}$.

С другой стороны, меры демографической политики 2006-2007 гг. привели к уплотнению календаря рождений и досрочной реализации репродуктивных планов поколений, которые в момент введения новых мероприятий были в наиболее активных фертильных возрастах. А это, по сути, самые многочисленные в последнее время поколения начала-середины 1980-х годов рождения. Соответственно, предстоящее структурное понижение уровня рождаемости, которое продлится не менее двух десятилетий, будет усилено сокращением ее интенсивности в результате обратных тайминговых подвижек.

Кроме того, согласно результатам нашего обследования 2008-2009 годов ${ }^{12}$, максимальное позитивное воздействие меры демографической политики оказали на уровень репродуктивных ожиданий когорт второй половины 1980-х годов рождения.

${ }^{10}$ Бодрова В. Сколько детей хотят иметь россияне? // Демоскоп Weekly, №81-82. 23 сентября - 6 октября 2002 г. [Электронный ресурc]. - URL:http://demoscope.ru/weekly/ 2002/081/tema01.php (дата обрашения: 20.06.2013).

${ }^{11}$ Российский статистический ежегодник - 2012 г. [Электронный ресурс]. - URL: http://www.gks.ru/bgd/regl/ b12_13/Main.htm (дата обращения: 20.06.2013).

12 Попова Л.А., Бутрим Н.А. Современные стандарты репродуктивного поведения населения и задачи просемейной демографической политики // Экономические и социальные перемены: факты, тенденции, прогноз: науч. журн. - Вологда, 2011. - №2(14). - С. 73-85. 
На репродуктивные установки малочисленных поколений 1990-х годов они практически не повлияли: уровень ожидаемой детности у них такой же, как и у родившихся в конце 1970-х - начале 1980-х годов. Т.е. предстоящее структурное понижение уровня рождаемости может оказаться усиленным не только досрочным исчерпанием итоговой детности поколений 1980-х годов рождения, но и пониженной репродуктивной активностью поколений 1990-х.

В этих условиях, бесспорно, требуется активизация демографической политики. Первый шаг был сделан в Федеральном послании 2010 г., в котором Президент предложил Правительству совместно с регионами проработать порядок единовременного предоставления на безвозмездной основе земельных участков под строительство жилого дома или дачи семьям при рождении третьего (или последующего) ребенка. В соответствии с этим, в ряде субъектов федерации в 2011 г. были разработаны региональные законы о бесплатном предоставлении земельных участков в собственность многодетным семьям.

Многие регионы в 2011 г. приняли законы о региональном материнском капитале при рождении третьего и последующих детей. Так, например, в Республике Коми с 1 июля 2011 г. вступил в силу республиканский закон «О дополнительных мерах социальной поддержки семей, имеющих детей, на территории Республики Коми» от 29.04.2011 года ${ }^{13}$ №45. Размер регионального семейного капитала составляет 150 тыс. руб. Он может быть реализован по истечении шести месяцев

${ }^{13} \mathrm{O}$ дополнительных мерах социальной поддержки семей, имеющих детей, на территории Республики Коми: Закон Республики Коми от 29.04.2011 г. №45 // Республика. - 2011. - №98. - 12 мая. со дня рождения третьего ребенка или последующих детей, рожденных в период с 1 января 2011 по 31 декабря 2016 г. Средства его могут быть направлены на улучшение жилищных условий, получение ребенком (детьми) образования, получение ребенком (детьми) платных медицинских услуг. Кроме того, этим законом предусмотрена ежегодная единовременная выплата за счет средств регионального семейного капитала в размере 25 тыс. руб., которая может быть направлена на оплату занимаемого семьей жилого помещения и коммунальных услуг, на оплату содержания ребенка (детей) в дошкольных учреждениях, на уплату налогов, на страхование имущества семьи, на страхование жизни ребенка (детей). В 2011 г. общий коэффициент рождаемости в Коми составил 13,1\%о против 12,9\%о в 2010 г. При этом родилось 1363 ребенка третьего и более порядка, что на 7,5\% больше, чем в 2010 г. Удельный вес рождений высокого порядка в 2011 г. составил $11,7 \%$ против $10,9 \%$ в 2010 г.

Однако меры, ориентированные на третьего ребенка, оказались, по сути, адресованными тем же самым поколениям, которые ранее откликнулись на мероприятия по стимулированию второго рождения. Т.е. они также способствуют уплотнению календаря рождений и еще более полному исчерпанию итоговой детности относительно многочисленных когорт 1980-х годов рождения. Соответственно, в ближайшие годы эти поколения практически не будут вносить вклад в уровень рождаемости, и он преимущественно будет определяться репродуктивным поведением малочисленных когорт 1990-х годов рождения. Иными словами, в настоящее время требуется не просто очередное усиление демографической политики. Она должна быть переадресована именно этим поколениям, на модели репродуктивного поведе- 
ния которых ни федеральные инициативы в демографической сфере 2006-2007 гг., ни региональные законы 2011 г. заметного позитивного влияния не оказали.

Таким образом, федеральные мероприятия демографической политики 20062007 гг. позволили продлить позитивные тенденции рождаемости начала 2000-х годов, проявившие уже в 2005-2006 гг. признаки стагнации. Это видно по динамике всех показателей рождаемости. Региональные меры позволили несколько увеличить в 2012 г. прирост рождаемости, значительно сократившийся в 2009-2011 гг. Т.е. уже в условиях ухудшения возрастной структуры репродуктивных контингентов в России продолжает сохраняться позитивный тренд рождаемости.

В то же время рост суммарного коэффициента рождаемости во многом является следствием изменений в календаре рождений. Если в уровне показателя 1999 г. во всей полноте отражается откладывание рождений, практиковавшееся населением на всем протяжении 1990-х годов и очень заметно проявившееся после кризиса 1998 г., то на уровень последних лет повышаюшее влияние оказывает реализация отложенных рождений старшими поколениями, а также уплотнение графика рождений у молодых когорт населения под влиянием федеральных и региональных демографических инициатив.

Негативное влияние возрастной структуры фертильных контингентов, начавшееся в 2010-2011 гг., в самое ближайшее время обусловит снижение уровня рождаемости. Структурное понижение может оказаться усиленным досрочным исчерпанием итоговой детности поколениями 1980-х годов рождения, а также недостаточной репродуктивной активностью поколений 1990-х.
Даже в условиях дальнейшей активизации демографической политики стране предстоит длительный период снижения рождаемости. Поэтому при разработке новых мер демографической политики следует акцентировать большее внимание на улучшении качественной структуры рождаемости, на укреплении института семьи, возрождении и усилении духовно-нравственных традиций семейных отношений. Отметим, что самой просемейной мерой демографической политики можно считать приоритет вторым рождениям, поскольку именно они являются наиболее семейными. На наш взгляд, сегодня требуется переориентация мероприятий демографической политики именно на вторые рождения. Тем более что адресатом обновления и усиления мер, ориентированных на стимулирование вторых рождений, в настоящее время окажутся поколения 1990-х годов рождения, активизация репродуктивного поведения которых отвечает долгосрочным целям демографического развития страны.

В области снижения смертности успехи в 2000-х годах тоже очень впечатляющие. С 2004 г. в России наблюдается понижающийся тренд уровня смертности. Снижение не вполне последовательное: в 2005 и 2010 гг. наблюдались некоторые повышения общего коэффициента смертности но в целом за период 2003-2012 гг. его величина уменьшилась с 16,4 умерших в расчете на 1000 человек населения до 13,3\%o ${ }^{14}$ (на $18,9 \%)$. Ожидаемая продолжительность жизни населения России увеличилась с 64,8 года в 2003 г. до 69,8 - в 2011 г. (у мужчин - с 58,5 до 64 лет, у женщин с 71,9 до 75,6 года) (табл. 4).

14 Демоскоп Weekly №543-544, 18 февраля - 3 марта 2013 г. [Электронный ресурс]. - URL: http://demoscope. ru/weekly/2013/0543/barom01.php. (дата обращения: 20.06.2013) 
Таблица 4. Ожидаемая продолжительность жизни при рождении населения Российской Федерации, лет

\begin{tabular}{|c|c|c|c|c|c|c|c|}
\hline Год & Оба пола & Мужчины & Женщины & Год & Оба пола & Мужчины & Женщины \\
\hline 1959 & 67,9 & 63,0 & 71,5 & 1999 & 65,9 & 59,9 & 72,4 \\
\hline 1970 & 68,9 & 63,2 & 73,6 & 2000 & 65,0 & 58,9 & 72,4 \\
\hline 1979 & 67,6 & 61,5 & 73,1 & 2001 & 65,2 & 58,9 & 72,2 \\
\hline 1987 & 70,1 & 64,9 & 74,6 & 2002 & 65,0 & 58,7 & 71,9 \\
\hline 1989 & 69,6 & 64,2 & 74,5 & 2003 & 64,8 & 58,5 & 71,9 \\
\hline 1990 & 69,2 & 63,7 & 74,3 & 2004 & 65,3 & 58,9 & 72,3 \\
\hline 1991 & 69,0 & 63,5 & 74,3 & 2005 & 65,3 & 58,9 & 72,4 \\
\hline 1992 & 67,9 & 62,0 & 73,8 & 2006 & 66,7 & 60,4 & 73,3 \\
\hline 1993 & 65,1 & 58,9 & 71,9 & 2007 & 67,6 & 61,5 & 74,0 \\
\hline 1994 & 64,0 & 57,6 & 71,2 & 2008 & 68,0 & 61,9 & 74,3 \\
\hline 1995 & 64,6 & 58,2 & 71,7 & 2009 & 68,8 & 62,9 & 74,8 \\
\hline 1996 & 65,8 & 59,6 & 72,4 & 2010 & 68,9 & 63,1 & 74,9 \\
\hline 1997 & 66,6 & 60,8 & 72,9 & 2011 & 69,8 & 64,0 & 75,6 \\
\hline 1998 & 67,0 & 61,3 & 72,9 & & & & \\
\hline
\end{tabular}

Источники: Демографический ежегодник России: стат. сб. - М., 2000. - С. 105; Российский статистический ежегодник - 2012 г. [Электронный ресурс]. - URL: http://www.gks.ru/bgd/regl/b12_13/lssWWW.exe/Stg/d1/04-01.htm (дата обращения: 20.06.2013).

Как известно, с 2006 г. в Российской Федерации реализуется политика реформирования здравоохранения. С 1 января указанного года стартовал национальный проект «Здоровье». В его рамках предусмотрены мероприятия по развитию первичной медико-санитарной помощи и совершенствованию профилактики заболеваний, по повышению доступности и качества специализированной, в том числе высокотехнологичной, медицинской помощи, по совершенствованию медицинской помощи матерям и детям, по формированию здорового образа жизни населения.

Учитывая специфику российской смертности, безусловно, следует отметить также федеральные целевые программы «Повышение безопасности дорожного движения в 2006-2012 годах» (в рамках реализации постановления Правительства РФ от 20.02.2006 г. №100) и «Предупреждение и борьба с социально значимыми заболеваниями (2007-2012 годы)» (в рамках реализации постановления Правительства Российской Федерации от 10.05.2007 г. №280).
В утвержденной в октябре 2007 г. «Концепции демографической политики Российской Федерации на период до 2025 года» заложены конкретные количественные ориентиры не только по численности населения страны, но и по уровню продолжительности его жизни: стабилизация численности населения к 2015 году на уровне 142-143 млн. человек и создание условий для ее роста к 2025 году до 145 млн. человек, а также повышение качества жизни и увеличение ожидаемой продолжительности жизни к 2015 году до 70 лет, к 2025 году - до 75 лет ${ }^{15}$. При этом задачи в области смертности в перечне основных задач демографической политики страны совершенно справедливо поставлены на первое место. Акценты сделаны на сокращении уровня смертности прежде всего в трудоспособном возрасте от внешних причин; на сокращении уровня

15 Об утверждении Концепции демографической политики Российской Федерации на период до 2025 года: Указ Президента Российской Федерации от 09.10.2007 г. №1351 [Электронный ресурс]. - URL: http:// document.kremlin.ru/doc.asp?ID=041941 (дата обращения: 20.06.2013). 
материнской и младенческой смертности, укреплении репродуктивного здоровья населения, здоровья детей и подростков; на сохранении и укреплении здоровья населения, увеличении продолжительности активной жизни, создании условий и формировании мотивации для ведения здорового образа жизни, на существенном снижении заболеваемости социально значимыми и представляющими опасность для окружающих заболеваниями, на улучшении качества жизни больных, страдающих хроническими заболеваниями, и инвалидов.

Дальнейшим продолжением приоритетного национального проекта «Здоровье» явились финансируемые в основном за счет субсидий федерального Фонда обязательного медицинского страхования (которые дополняются финансированием из региональных бюджетов и средств региональных фондов ОМС) региональные программы модернизации здравоохранения на 2011-2012 гг. Их каждый регион разрабатывал самостоятельно в соответствии с обозначенными Минздравом направлениями, которые получат федеральное финансирование: укрепление материально-технической базы, внедрение современных информационных систем и единых стандартов медицинской помощи. Первое направление нацелено на выравнивание региональных систем здравоохранения и создание условий для внедрения стандартов. Цель информатизации повышение качества и доступности медицинских услуг, прозрачности финансирования.

Третья составляющая (введение стандартов) - определение набора медицинских услуг, который должен оказываться при том или ином заболевании. В стоимость стандарта (всего их предполагается 1190) закладывается все: лекарства, рас- ходные материалы, зарплата медперсонала, питание пациента ${ }^{16}$. При разработке программ региональные власти сами определяли, какие медицинские учреждения больше нуждаются в деньгах, какие уже готовы для внедрения стандартов и т.д. Программы были утверждены в 2011 г. в каждом российском регионе и должны были быть реализованы до конца 2012 г., однако они продлены и на текущий год.

Итак, каковы результаты этих мероприятий? Во-первых, следует отметить продолжительность периода снижения смертности, которое наблюдается в России уже на протяжении девяти лет, т.е. оно достаточно устойчиво (небольшие отклонения 2005 и 2010 гг. мы уже отметили). Иными словами, его уже нельзя оценивать как непродолжительное снижение компенсаторного типа, происходящее после ряда лет сверхсмертности, приводящее к «оздоровлению населения», как, например, вполне можно оценить снижение смертности российского населения в период 1995-1998 гг.

Во-вторых, достигнутый уровень продолжительности жизни населения. Как известно, максимальные уровни продолжительности жизни населения России были отмечены в середине 1960-х и в конце 1980-х годов. В середине 1960-х годов продолжительность жизни достигла 64,6 года у мужчин (в 1964-1965 гг.) и 73,54 года у женщин (в 1967-1968 гг.), после чего практически два десятилетия наблюдались стагнация и снижение ее величины. А показатели ожидаемой продолжительности жизни 1986-1987 гг., составившие 70,13 года для всего населения, 64,91 - для мужчин и 74,55 - для женщин ${ }^{17}$, являются максимальными за

\footnotetext{
${ }^{16}$ http://expert.ru/ural/2012/31/reanimatsiya-bespolezna/ (дата обращения: 20.06.2013).

17 Демографический ежегодник Российской Федерации. 1993: стат. сб. - М., 1994.
} 
всю российскую историю. В 2011 г., после восьми лет сокращения уровня смертности, величина продолжительности жизни для обоих полов, составившая 69,8 года $(64 \text { - для мужчин и 75,6 - для женщин })^{18}$, почти достигла рекордного уровня 19861989 гг. При этом по женскому показателю максимальная отметка была перекрыта еще в 2009 г., а вот по мужскому - пока не достигнут даже максимум середины 1960-х. Однако, как видим, в 2011 г. уровень, которого в соответствии с целью «Концепции демографической политики до 2025 года» предполагалось достигнуть к 2015 г., практически уже достигнут.

B-третьих, темпы снижения смертности по причинам смерти. Наиболее значительно в целом за 2003-2011 гг. уменьшились показатели смертности населения от внешних причин (несчастные случаи, отравления, травмы, убийства, самоубийства): у мужчин на 40,5\%, у женщин на $38,9 \%{ }^{19}$. На втором месте - снижение смертности от болезней органов дыхания. У мужчин смертность от этой группы причин сократилась на 27,9\%, у женщин - на 21,6\%. На третьем месте у мужчин - болезни системы кровообращения (сокращение на 19,4\%). У женщин немного более значительно уменьшилась смертность от некоторых инфекционных и паразитарных болезней (на 19,1\%), в то время как снижение смертности от болезней системы кровообращения составило 18,3\%. У мужчин уменьшение смертности от инфекционных и паразитарных болезней (на 15,6\%) - на четвертом месте.

\footnotetext{
${ }^{18}$ Российский статистический ежегодник - 2012 г. [Электронный ресурc]. - URL: http://www.gks.ru/bgd/regl/ b12_13/IssWWW.exe/Stg/d1/04-01.htm (дата обращения: 20.06.2013).

19 Сайт Федеральной службы государственной статистики. - URL: http://www.gks.ru/wps/wcm/connect/ rosstat_main/rosstat/ru/statistics/population/demography/\# (дата обращения: 20.06.2013).
}

Если же брать период, когда уже начали действовать государственные инициативы в области снижения смертности, то в 2006-2011 гг. смертность от болезней системы кровообращения занимает второе место по темпам снижения после внешних причин. А в 2011 г., когда начали реализовываться региональные программы модернизации здравоохранения, темпы снижения смертности от болезней системы кровообращения и от внешних причин уже сопоставимы: у мужчин, соответственно, 6,3 и $8,2 \%$, у женщин 6,9 и $8 \%$.

В-четвертых, свидетельством того, что в снижении смертности населения России 2000-х годов весомый вклад принадлежит мероприятиям, связанным с модернизацией здравоохранения, может являться также недостаточный рост уровня продолжительности жизни в регионах с высокой долей смертности от внешних причин. Мы рассматриваем это в качестве гипотезы на примере Республики Коми. В период 19941998 гг, когда в стране наблюдалось снижение смертности компенсаторного типа, произошло очень значительное сближение продолжительности жизни населения республики с общероссийским уровнем: разница сократилась с трех лет практически до нуля. В 2000-е годы, в условиях более продолжительного периода снижения смертности, разница в продолжительности жизни с общероссийским уровнем составляла всё ещё порядка двух лет.

В заключение отметим, что в 2012 г. в результате встречных тенденций рождаемости и смертности в целом по стране число родившихся почти сравнялось с числом умерших: отношение числа умерших к числу родившихся составило 100,1\% против 107,3\% за 2011 год $^{20}$.

${ }^{20}$ Демоскоп Weekly №543-544, 18 февраля - 3 марта 2013 г. [Электронный ресурc]. - URL: http://demoscope. ru/weekly/2013/0543/barom01.php. (дата обращения: 20.06.2013). 
Уровень продолжительности жизни населения России практически достиг 70 лет. Но это лишь половина успеха: такая цифра в России уже фиксировалась четверть века назад, и это почти на 10 лет позже, чем в странах Евросоюза. Необходимо дальнейшее углубление мероприятий, связанных с модернизацией здравоохранения: ускорение процесса постарения населения России ставит этот вопрос со всей остротой. Кроме того, в России по-прежнему очень большой резерв повы- шения продолжительности жизни, связанный с неблагоприятным образом жизни населения. И это не медицинская, а социальная проблема. По уровню рождаемости страна сегодня стоит на пороге очередного структурного понижения. В этих условиях на первое место выходит задача повышения уровня репродуктивных установок малочисленных поколений 1990-х годов рождения и степени их реализации, т.е. переориентации мероприятий демографической политики в пользу этих поколений.

\section{Литература}

1. Бодрова, В. Сколько детей хотят иметь россияне? / В. Бодрова // Демоскоп Weekly, №81-82. 23 сентября - 6 октября 2002 г. [Электронный ресурс]. - URL: http:// demoscope.ru/weekly/2002/081/tema01. php (дата обращения: 20.06.2013).

2. Демографический ежегодник Российской Федерации. 1993: стат. сб. - М., 1994.

3. Демоскоп Weekly №543-544, 18 февраля - 3 марта 2013 г. [Электронный ресурс]. - URL: http://demoscope. ru/weekly/2013/0543/barom01.php. (дата обращения: 20.06.2013).

4. Захаров, С. Какой будет рождаемость в России / С. Захаров // Демоскоп Weekly, №495-496. 23 января 5 февраля 2012 г. [Электронный ресурc]. - URL: http:// demoscope.ru/weekly/2012/0495/tema01.php (дата обращения: 20.06.2013).

5. Краткие итоги выборочного обследования «Семья и рождаемость» [Электронный ресурс]. URL: http://www.gks.ru/free_doc/2010/family.htm (дата обращения: 20.06.2013).

6. Об актах гражданского состояния: Федеральный закон №143 от 15 ноября 1997 г. // Российская газета. - 1997. - №224. - 20 нояб.

7. Об обеспечении пособиями по временной нетрудоспособности, по беременности и родам граждан, подлежащих обязательному социальному страхованию: Федеральный закон от 29 декабря 2006 г. №255 // Российская газета. - 2006. - №279. - 12 дек.

8. Об утверждении Концепции демографической политики Российской Федерации на период до 2025 года: Указ Президента Российской Федерации от 09.10.2007 г. №1351 [Электронный ресурс]. - URL: http://document.kremlin.ru/doc.asp?ID=041941 (дата обращения: 20.06.2013).

9. О внесении изменений в отдельные законодательные акты Российской Федерации в части государственной поддержки граждан, имеющих детей: Федеральный закон от 5 декабря 2006 г. №207 // Российская газета. - 2006. - №279. - 12 дек.

10. О дополнительных мерах социальной поддержки семей, имеющих детей, на территории Республики Коми: Закон Республики Коми от 29.04.2011 г. №45 // Республика. - 2011. - №98. - 12 мая.

11. О дополнительных мерах государственной поддержки семей, имеющих детей: Федеральный закон №256 // Российская газета. - 2006. - №279. - 12 дек.

12. Попова, Л.А. Современные стандарты репродуктивного поведения населения и задачи просемейной демографической политики / Л.А. Попова, Н.А. Бутрим // Экономические и социальные перемены: факты, тенденции, прогноз: науч. журн. - Вологда, 2011. - №2(14). - С. 73-85.

13. Российский статистический ежегодник - 2012 г. [Электронный pecypc]. - URL: http://www.gks.ru/bgd/ regl/b12_13/Main.htm (дата обращения: 20.06.2013).

14. Сайт Федеральной службы государственной статистики. - URL: http://www.gks.ru/wps/wcm/connect/ rosstat_main/rosstat/ru/statistics/population/demography/\# (дата обращения: 20.06.2013).

15. Электронный ресурс]. - Режим доступа: http://expert.ru/ural/2012/31/reanimatsiya-bespolezna/ (дата обращения: 20.06.2013). 


\section{References}

1. Bodrova V. Skol'ko detey khotyat imet' rossiyane? [How Many Children Do the Russians Want to Have?]. Demoskop Weekly [Demoscope Weekly], no.81-82, September 23 - October 6, 2002. Available at: http:// demoscope.ru/weekly/2002/081/tema01.php (accessed June 20, 2013).

2. Demograficheskiy ezhegodnik Rossiyskoy Federatsii. 1993: stat. sb. [Demographic Yearbook of the Russian Federation. 1993: Statistical Digest]. Moscow, 1994.

3. Demoskop Weekly №543-544, 18 fevralya - 3 marta 2013 g. [Demoscope Weekly, no.543-544, February 18 - March 3, 2013]. Available at: http://demoscope.ru/weekly/2013/0543/barom01.php. (accessed June 20, 2013).

4. Zakharov S. Kakoy budet rozhdaemost' v Rossii [What the Birth Rate in Russia Will Be]. Demoskop Weekly [Demoscope Weekly], no. 495-496, January 23 -February 5, 2012. Available at: http://demoscope.ru/ weekly/2012/0495/tema01.php (accessed June 20, 2013).

5. Kratkie itogi vyborochnogo obsledovaniya "Sem'ya i rozhdaemost" [ [Brief Results of the Sample Survey "Family and Fertility"]. Available at: http://www.gks.ru/free_doc/2010/family.htm (accessed June 20, 2013).

6. Ob aktakh grazhdanskogo sostoyaniya: Federal'nyy zakon № 143 ot 15 noyabrya 1997 g. [Federal Law “On Civil Status Acts" No.143 of November 15, 1997]. Rossiyskaya gazeta [The Russian Newspaper], 1997, no.224, November 20.

7. Ob obespechenii posobiyami po vremennoy netrudosposobnosti, po beremennosti i rodam grazhdan, podlezhashchikh obyazatel'nomu sotsial'nomu strakhovaniyu: Federal'nyy zakon ot 29 dekabrya 2006 g. №255 [Federal Law "On the Provision of Temporary Disability Allowances, Maternity Allowances to the Citizens Subject to Compulsory Social Insurance" No.255-FL of December 29, 2006]. Rossiyskaya gazeta [The Russian Newspaper], 2006, no.279, December 12.

8. Ob utverzhdenii Kontseptsii demograficheskoy politiki Rossiyskoy Federatsii na period do 2025 goda: Ukaz Prezidenta Rossiyskoy Federatsii ot 09.10.2007g. №1351 [Decree of the President of the Russian Federation “On the Approval of the Concept for Demographic Policy of the Russian Federation for the Period up to 2025" No.1351 of October 9, 2007]. Available at: http://document.kremlin.ru/doc.asp?ID=041941 (accessed June 20, 2013).

9. O vnesenii izmeneniy v otdel'nye zakonodatel'nye akty Rossiyskoy Federatsii v chasti gosudarstvennoy podderzhki grazhdan, imeyushchikh detey: Federal'nyy zakon ot 5 dekabrya 2006 g. №207 [Federal Law “On the Introduction of Amendments to Certain Legislative Acts of the Russian Federation on the Provision of State Support to the Citizens with Children” No.207-FL of December 5, 2006]. Rossiyskaya gazeta [The Russian Newspaper], 2006, no.279, December 12.

10. O dopolnitel'nykh merakh sotsial'noy podderzhki semey, imeyushchikh detey, na territorii Respubliki Komi: Zakon Respubliki Komi ot 29.04.2011 g. №45 [Law of the Republic of Komi "On Additional Measures of Providing Social Support to Families with Children, on the Territory of the Republic of Komi” No.45 of April 29, 2011]. Respublika [Republic], 2011, no.98, May 12.

11. O dopolnitel'nykh merakh gosudarstvennoy podderzhki semey, imeyushchikh detey: Federal'nyy zakon №256 [Federal Law "On Additional Measures of State Support to Families with Children" No.256-FL of December 29, 2006]. Rossiyskaya gazeta [The Russian Newspaper], 2006, no.279, December 12.

12. Popova L.A., Butrim N.A. Sovremennye standarty reproduktivnogo povedeniya naseleniya i zadachi prosemeynoy demograficheskoy politiki [Modern Standards of Reproductive Behavior of the Population and the Objectives of Pro-Family Population Policy]. Ekonomicheskie i sotsial'nye peremeny: fakty, tendentsii, prognoz [Economic and Social Changes: Facts, Trends, Forecast], 2011, no.2(14), pp. 73-85.

13. Rossiyskiy statisticheskiy ezhegodnik - 2012 g. [Russian Statistical Yearbook - 2012]. Available at: http://www. gks.ru/bgd/regl/b12_13/Main.htm (accessed June 20, 2013).

14. Sayt Federal'noy sluzhby gosudarstvennoy statistiki [Federal State Statistics Service Website]. Available at: http:// www.gks.ru/wps/wcm/connect/rosstat_main/rosstat/ru/statistics/population/demography/\# (accessed June 20, 2013).

15. Belousov A. Reanimatsiya bespolezna [Resuscitation Is Useless]. Ekspert-Ural [Expert-Ural], no.28-31(519), July 16 - August 12. Available at: http://expert.ru/ural/2012/31/reanimatsiya-bespolezna/ (accessed June 20, 2013). 


\section{К проблеме теории среднего класса: история и современность}

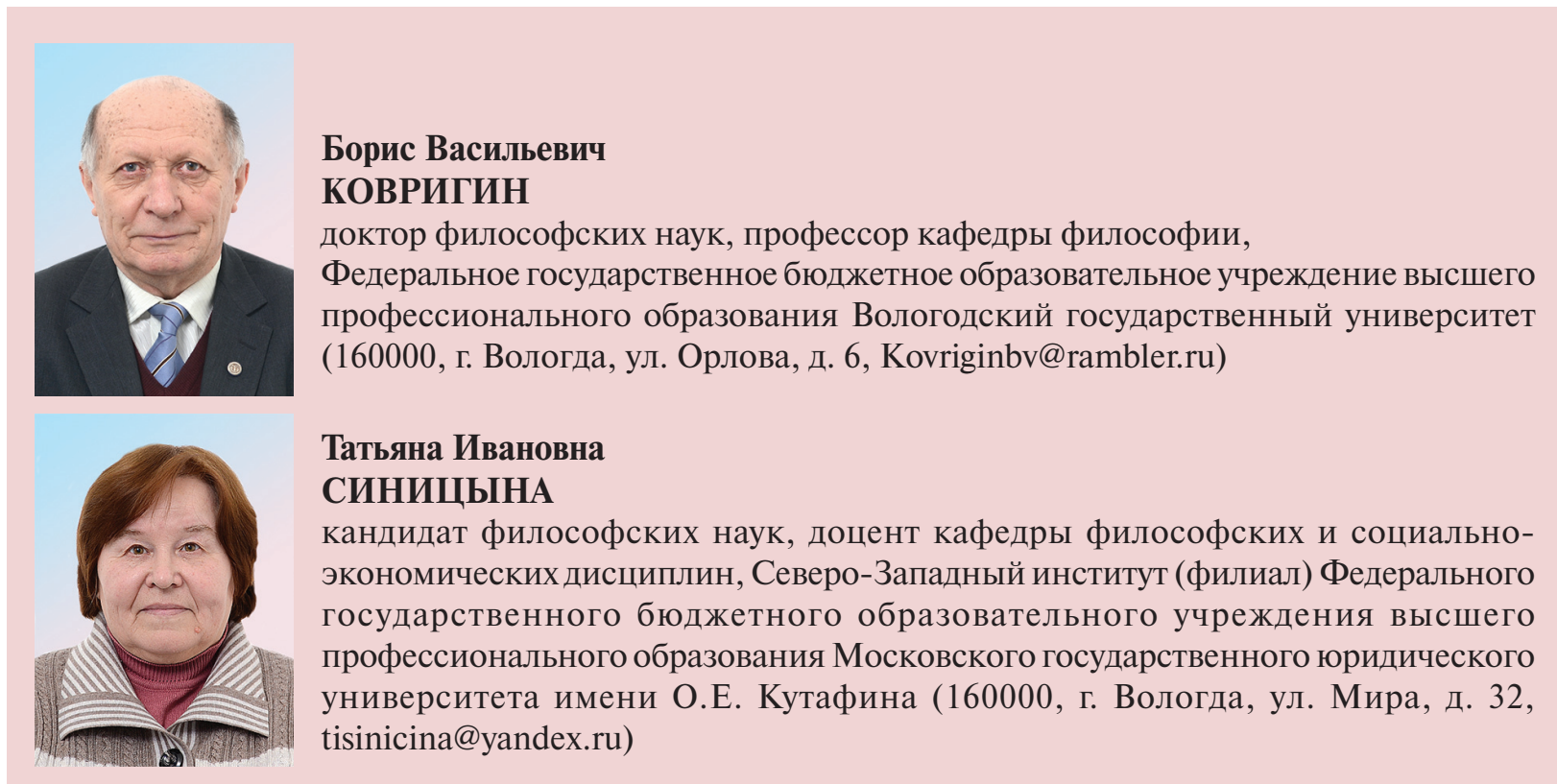

Аннотация. В статье анализируется проблема среднего класса, поставленная еще в античном обществе в работах Аристотеля, интересовавшая социальных мыслителей в эпоху Возрождения и в Новое время. В современных условиях данный вопрос активно обсуждается как в зарубежной, так и в российской печати. Авторы статьи показывают причины зачастую противоречивых оценок численности среднего класса в российском обществе (в том числе в Вологодской области) и перспективу роста удельного веса средних слоев.

Ключевые слова: средний класс, стратификация, модернизация, дифференциация, статус, самоидентификация, уровень жизни, отчуждение.

Kovrigin B.V., Sinitsyna T.I.

\section{About middle class theory: history and modern times}

Kovrigin Boris Vasil'evich - Doctor of Philosophy, Professor of the Philosophy Faculty, Federal State-Financed Educational Institution of Higher Professional Education the Vologda State Pedagogical University (6, Orlov Street, Vologda, 160000, Russia, Kovriginbv@rambler.ru)

Sinitsyna Tat'yana Ivanovna - Ph.D.in Philosophy, Associate Professor of the Faculty of Philosophy and Socio-Economic Disciplines, North-Western Institute (branch) of the Federal State-Financed Educational Institution of Higher Professional Education O.Ye. Kutafin Moscow State Law University (MSLU) (32, Mira Street, Vologda, 160000, Russia, tisinicina@yandex.ru) 
Abstract. The article analyses the problem of the middle class that had been denoted in the works of Aristotle as far back as in ancient society and that was of interest to social thinkers during the Renaissance and Modern Age periods. At present this issue has been actively discussed both in foreign and in the Russian press. The authors of the article show the reasons for frequent contradictions between the assessments concerning the size of the middle class in Russian society (including the Vologda Oblast) and the prospect for the increase in the share of middle stratum.

Keywords: Middle class, stratification, modernization, differentiation, status, self-identification, standard of living, estrangement.

На современном этапе развития общества возникают проблемы, зачастую связанные с неопределенностью и всевозможными рисками, в том числе с риском реализации катастрофических сценариев реальных событий. Все в большей степени проявляются нелинейные свойства среды, увеличивающей сложность событийного пространства и приводящей к свойственному нелинейным системам возрастанию вероятности свершения даже маловероятных событий.

Современная общественная жизнь актуализирует задачу модернизации общественного развития. Большинство стран вынуждено наращивать свой национальный ресурс, повышать способность к социальным преобразованиям, чтобы суметь обеспечить свои интересы, конкурентоспособность в мировой экономике, достойно отвечать на вызовы природы, техногенные и социогенные угрозы. В этой непростой ситуации необходимо правильно определиться с движущими силами модернизации общества. По мнению современных исследователей, «главным и непосредственным фактором изменения повседневных социальных практик» [5, с. 4] служит активность не столько элиты и верхнего слоя, сколько среднего, базового и нижнего слоев, составляющих основную часть общества. Преодоление разрыва между очень богатыми и нищими слоями, увеличение численности среднего класса способствует также устойчивости общественного развития, преодолению отчуждения между людьми.
Современные суждения о роли среднего класса в общественном развитии имеют своими предпосылками идеи, сформулированные еще в античности. Тема среднего класса была четко поставлена Аристотелем в его «Политике». Проанализировав существовавшие в то время формы правления, философ отдавал предпочтение политии как смешанной форме государственного строя. «Те виды государственного устройства, которые отклоняются более в сторону олигархии, называют аристократиями, а те, которые более склоняются в сторону демократии, политиями» [1, с. 540].

Аристотель утверждал, что умеренность и середина являются наилучшими из всех благ, поэтому лучше всего иметь средний достаток. Основанием для такого вывода он выдвигает идею, согласно которой, имея средний достаток, легче подчиняться доводам разума, ближе становится идея о равенстве и равноправии, так как «государство, состоящее из средних людей, будет иметь и наилучший государственный строй. Если же одни владеют слишком многим, а другие же ничего не имеют, возникает либо крайняя демократия, либо олигархия, либо в чистом виде тирания» [там же, с. 507]. Таким образом, устойчивость государства Аристотель напрямую связывает с наличием и преобладанием в нем средних слоев общества.

Средний класс - наилучший, поскольку по условиям своей жизни он в большей степени, чем остальные, готов следовать 
разумному установлению, закону и справедливости, тогда как богачи и бедняки не склонны следовать этим принципам.

Аналогичные мысли, спустя почти два тысячелетия, высказывает известный мыслитель эпохи Возрождения Никколо Макиавелли в своем главном произведении «Государь». Признавая факт наличия в государстве богатых и бедных, он считал нецелесообразным доверять управление ни тем, ни другим.

Философы более позднего времени (Т. Гоббс, Д. Локк, Ж.-Ж. Руссо) вполне отчетливо осознавали, что наличие в обществе социальных классов и слоев, не равных по своей сути, имеет место, и это влечет за собой разного рода социальные катаклизмы и проблемы. Систематизированной теоретической базы еще не было сформулировано, однако предпосылки для создания теории классов и стратификации уже были заложены. Впоследствии идеи классов, социального неравенства и классовой борьбы были проанализированы и систематически изложены историками, экономистами и философами XVIII начала ХІХ в. (А. Смит, Э. Кондильяк, К. Сен-Симон, Ф. Гизо, О. Миньё и др.). К. Маркс в своей теории классов во многом опирался на эти труды.

Идея среднего класса становится наиболее распространенной в западной социологии во второй половине XX века. Как итог развития НТР, диффузии собственности в ходе реформ в США и других развитых капиталистических государствах происходит сокращение доли неимущих слоев населения. Для основной массы населения становится характерным сопоставимый уровень доходов.

Современные социальные исследования служат основанием для вывода о том, что средний класс становится массовым явлением при переходе общества в индустриальную и особенно постиндустри- альную стадию развития. Расширению и становлению его «способствовали развитие технологий и третичного сектора экономики, а также особого типа государства («социальное государство» и «Welfare State»)» $[8$, c. 26].

Другая наметившаяся тенденция современного развития общества связана с возрастающей дифференциацией самого среднего класса, как результат этого акцент исследований смещается на составляющие его отдельные группы. В центре внимания исследователей оказываются сначала «новый» средний класс, затем «профессионалы» - обладатели уникального человеческого капитала, а в последние годы и так называемые «информационные работники». Начиная с 1980-х гг. средний класс рассматривается как «совокупность качественно различных социальных групп» [там же], оказывающая стабилизирующее воздействие на общество.

Вместе с тем существует и альтернативная точка зрения, главная идея которой заключается в том, что «средний класс- это новый (для нас) социальный миф» [7, с. 16]. Средний класс, с точки зрения представителей данной концепции, - это «весьма сложная мифологема, связанная с перенесением на российскую реальность внешних ценностно нагруженных образов своего потенциального будущего, определяемого через подсмотренное чужое настоящее» [там же, с. 17].

В качестве критериев выделения классов, слоев, страт наиболее адекватной видится многомерная стратификация, предложенная М. Вебером, П.А. Сорокиным и другими социологами. Так, М. Вебер рассматривал власть, собственность и престиж как три взаимодействующих фактора, которые, по его мнению, лежат в основе иерархического построения любого общества. Согласно ему, обладание властью, то есть возможностью воздействия 
на других, пронизывает все сферы общественного бытия. Различия в собственности порождают экономические классы, в свою очередь экономическое положение дает возможность (или не позволяет) распоряжаться товарами и квалификацией с целью получения дохода в рамках конкретной экономической системы. Различия в отношении к власти порождают большие группы людей, именуемые партиями, а престижные различия образуют группировки людей по статусам [3].

Признавая неоднородность феномена «средний класс», современные исследователи предлагают использовать метод кластерного анализа общества и его основных групп. Для выделения основных групп внутри среднего класса вводятся переменные, характеризующие экономический ресурс, в том числе наличие доходов от собственного бизнеса, собственности; властный ресурс - возможность влиять на принятие решений в масштабах конкретной социальной организации; квалификационный ресурс уровень образования, квалификации, стремление к ее повышению; культурный ресурс как характеристика среды первичной социализации.

В России проблемами среднего класса занимаются в основном социологи и экономисты (Т.И. Заславская, А.Г. Здравомыслов, В.В. Радаев, О.И. Шкаратан, Н.Е. Тихонова, С.В. Горюнова, А.А. Шабунова и др.). $\mathrm{K}$ современному российскому обществу они применяют те же критерии отнесения к среднему классу, что и на Западе, а именно: a) средний (для определенной страны) уровень благосостояния и постоянные источники дохода; б) высокий уровень образования и профессиональной квалификации; в) высокий уровень мобильности (в том числе и внутри среднего класса); г) стремление к общественной стабильности (менталитет данного слоя общества предполагает реформизм, индивидуализм, поддержку существующего режима) [см., например, 6].

По мнению Т.И. Заславской, средний класс правомерно толковать как исполняющий интерактивную функцию «социального медиатора», ввиду его промежуточной позиции между верхами и низами общества; выступающий социальным стабилизатором общества, ввиду сравнительно высокой материальной обеспеченности; исполняющий роль главного агента технологического и социально-экономического прогресса, ввиду высокой интеллектуальной квалификации; являющийся носителем общественных интересов и национальной культуры [5, с. 4]. Это и делает средний класс в определенной степени самодостаточной и относительно независимой частью населения, которая является своего рода «буфером» между двумя непримиримыми полюсами - бедными и богатыми слоями общества. Поэтому чем тоньше прослойка среднего класса, тем вероятнее столкновение этих двух антагонистических групп населения.

Росту среднего класса, количественному и качественному, способствует развитие промышленности, науки, образования и сферы услуг. В промышленно развитых странах средний класс составляет, как правило, большинство населения (от 60 до $70 \%$ ).

Роль среднего класса заключается в том, что он выступает в качестве основной социальной базы гражданского общества, является оппонентом крупной буржуазии, высшим чиновникам и экстремистски настроенной части низших слоев общества. Кроме того, средний класс - это основная составляющая производительных сил общества, способная напряженно трудиться, осваивать новые знания, заниматься творчеством, воспитывать новое поколение и т.д. 
Средний класс заинтересован в сохранении такого общественного строя, который предоставит (создаст) ему условия для успешного развития. Крайние социальные слои (чрезмерно богатые и нищие) справедливо относятся к факторам нестабильности.

Мониторинг, проведенный в 2010 году с целью подготовки стратегии модернизации регионов, дает возможность описать состояние социальной структуры взрослого населения России и отдельных регионов, социальное самочувствие и отношение населения к общественным институтам, оценить качество жизни различных социальных слоев и высветить некоторые общие и региональные проблемы, стоящие перед страной, пытающейся осуществить модернизацию.

В соответствии с Типовой методикой ООН средний класс выделяется по совокупности нескольких критериев: уровню образования, материальному положению и самоидентификации.

Данные статистики в совокупности с мнением самого населения о своем уровне жизни приводят к заключению, что «численность бедного населения за первое десятилетие XXI в. стабилизировалась на уровне одной трети взрослого населения страны, а вместе с теми, кто относит себя к необеспеченным, численность составляет 50\%» [2, с. 9-10]. Эти данные мониторинга вполне сопоставимы с результатами, полученными в Европейском социальном исследовании, согласно которому в 2010 г., по мнению $55 \%$ россиян, жить на получаемый ими доход было трудно или очень трудно. Официально зафиксировано «чрезмерное расслоение» граждан по уровню жизни: $10 \%$ самых обеспеченных россиян получают доход в 15-17 раз больше, чем $10 \%$ самых бедных (по данным Росстата). В.В. Путин в одной из предвыборных статей в 2012 г. отнес к среднему классу 20-25\% населения России.
Анализ оценки населением своего материального положения, проведенный по Вологодской области, показал, что в 2010 г. 9\% жителей вошли в группы «зажиточных» и «богатых». За период кризиса 20082009 гг. в регионе возросла доля самых нижних слоев населения - «бедных» И «нищих» (с 29 до 33\%) и «необеспеченных» (с 22 до $26 \%)$. Таким образом, на долю «обеспеченных» пришлось примерно 32\%. Произошло резкое снижение социального статуса у $15 \%$ населения региона [9, с. 21].

Руководитель Центра стратегических исследований Госстраха России А. Зубец приводит такие финансовые критерии отнесения к среднему классу: нижний порог начинается с 50 тыс. долларов год, или 46,3 тыс. руб. на члена семьи (из 3 человек) в месяц, что почти вдвое больше среднегодовой зарплаты в России; верхний порог - 300 тыс. долларов в год на семью, или 277,8 тыс. руб. на каждого члена семьи в месяц [газета «Труд». 2013. 2 августа].

О недостаточной роли фактора образованности в отнесении к среднему классу свидетельствует уровень среднемесячных зарплат по данным Росстата за минувший год (с июля 2012 по июль 2013 г.): врачи 38,7 тыс. руб., учителя - 28,9 тыс. руб., воспитатели, работники культуры и социальные работники соответственно - 22,2, 17,9 и 13,2 тыс. руб. [газета «Аргументы и факты». 2013. №333. 28 августа - 3 сентября]. Немногим отличаются от выплат врачам и учителям зарплаты преподавателей вузов, имеющих ученые степени и звания.

Вместе с тем субъективные оценки своего имущественного положения у значительной части россиян завышены (не по доходам, а «по ощущению»). По данным «Философской энциклопедии», $80 \%$ россиян (2000 год) считали себя обеспеченными [6], что свидетельствует о желании граждан приукрасить свое положение, несколько приподнять свой статус в обществе. 
Значительные расхождения в оценке численности среднего класса, на наш взгляд, объясняются тем, что: а) в некоторых случаях учитывается лишь доход главы семьи, в большинстве же исследований (и это правильно) общий доход семьи равномерно распределяется на всех ее членов; б) пенсионеры составляют около $30 \%$ населения страны, а их пособия равны $38 \%$ средней начисленной зарплаты (по данным 2013 года), поэтому 22\% россиян, живущих на пособие, вынуждены работать; в) численность среднего класса в России, по крайней мере, дважды резко падала: в 1998 г., при дефолте, и в период последнего кризиса 2008-2009 гг.

Особенность реального общественного слоя, именуемого средним классом, в том, что это открытая, сложная, неравновесная система, пополняемая из различных общественных групп, испытывающая давление и нижних слоев, и крупных собственников, различного рода управленческих структур. Одной из составляющих этой системы является когнитариат - «высокообразованные работники в сфере бизнеса, науки, культуры и других областей человеческой деятельности, опирающейся на специальные знания и информацию, с привлечением информационных технологий» [4, с. 4].

Когнитариат может быть идентифицирован как креативная, интеллектуальная составляющая среднего класса, которая формирует в постиндустриальном обществе и может стать ядром среднего класса, выразителем интересов интеллектуально развитых представителей работников как умственного, так и физического труда. Для сплочения и отстаивания собственных интересов он имеет в своих руках особые мобильные средства связи - социальные сети.

Представитель когнитариата - это уже не «одномерный человек» общества потребления (Г. Маркузе), его действия невозможно строго спрогнозировать. Даже малые, научно не обоснованные действия власти или капитала могут привести к резкому структурированию пока еще рыхлого социального слоя, обозначаемого как «средний класс». Открытость, нелинейность динамичной системы современного среднего класса может привести к образованию особых критических состояний общества, точек бифуркации, за которыми трудно предсказать направленность и характер социальных изменений.

В итоге большинство отечественных исследователей сходятся во мнении, что в России средний класс только формируется, но имеет перспективу расширения в недалеком будущем, по крайней мере, до 35-40\% самодеятельного населения. Но только достигнув уровня 60-70\%, он может стать основой стабильности общества, поскольку его представителям будет что терять, они заинтересованы не в потрясениях и катаклизмах, а в спокойном, устойчивом развитии и государства, и общества в целом.

\section{Литература}

1. Аристотель. Политика: соч.: в 4-х т. - М., 1983

2. Беляева, Л.А. Социокультурные аспекты модернизации регионов / Л.А. Беляева // Философские науки. 2012. - №7.

3. Вебер, М. Основные понятия стратификации / М. Вебер // Социологические исследования. 1994. - №5.

4. Вильховченко, Э.Д. «Люди знания» - новая рабочая сила позднекапиталистических обществ и ее место в цивилизационных процессах / Э.Д. Вильховченко. - М.: ИМЭМО РАН, 2010. 
5. Заславская, Т.И. Социальные трансформации в России / Т.И. Заславская, В.А. Ядов // Социологический журнал. - 2008. - №4.

6. Здравомыслов, А.Г. Средний класс / А.Г. Здравомыслов // Новая философская энциклопедия. М., 2000.

7. Средние классы в России: экономические и социальные стратегии / Е.М. Авраамова и др.; под ред. Т. Малеевой; Моск. Центр Карнеги. - М.: Гондальф, 2003.

8. Тихонова, Н.Е. Средний класс: теория и реальность / Н.Е. Тихонова, С.Е. Мареева. - М.: Альфа, 2009.

9. Шабунова, А.А. Через кризис к модернизации / А.А. Шабунова, М.А. Ласточкина // Философские науки. - 2012. - №7.

\section{References}

1. Aristotle. Politika: soch.: v 4-kht. [Politics: Complete Works: in 4 Volumes]. Moscow, 1983.

2. Belyaeva L.A. Sotsiokul'turnye aspekty modernizatsii regionov [Socio-Cultural Aspects of Regions' Modernization]. Filosofskie naukii [Philosophical Sciences], 2012, no.7.

3. Weber M. Osnovnye ponyatiya stratifikatsii [Basic Concepts of Stratification]. Sotsiologicheskie issledovaniya [Sociological Studies], 1994, no.5.

4. Vil'khovchenko E.D. "Lyudi znaniya" - novaya rabochaya sila pozdnekapitalisticheskikh obshchestv i ee mesto v tsivilizatsionnykh protsessakh ["People of Knowledge" - New Workforce of Late-Capitalist Societies and Its Role in Civilization Processes]. Moscow: IMEMO RAN, 2010.

5. Zaslavskaya T.I., Yadov V.A. Sotsial'nye transformatsii v Rossii [Social Transformations in Russia]. Sotsiologicheskiy zhurnal [Sociological Journal], 2008, no.4.

6. Zdravomyslov A.G. Sredniy klass [Middle Class]. Novaya filosofskaya entsiklopediya [New Encyclopedia of Philosophy]. Moscow, 2000.

7. Avraamova E.M. et al. Srednie klassy v Rossii: ekonomicheskie $i$ sotsial'nye strategii [Middle Classes in Russia: Economic and Social Strategies]. Ed. by T. Maleeva; Carnegie Moscow Centre. Moscow: Gondal'f, 2003.

8. Tikhonova N.E., Mareeva S.E. Sredniy klass: teoriya i real'nost' [Middle Class: Theory and Reality]. Moscow: Al'fa, 2009.

9. Shabunova A.A., Lastochkina M.A. Cherez krizis k modernizatsii [Through Crisis to Modernization]. Filosofskie nauki [Philosophical Sciences], 2012, no.7. 


\section{ОБЩЕСТВЕННЫЕ ФИНАНСЫ}

УДК 336.143(470.12), ББК 65.261.32-18(2Рос-4Вол)

(C) Печенская М.A.

\section{Бюджетная перспектива региона 2014-2016: исполнение социальных указов Президента или избежание риска дефолта?}

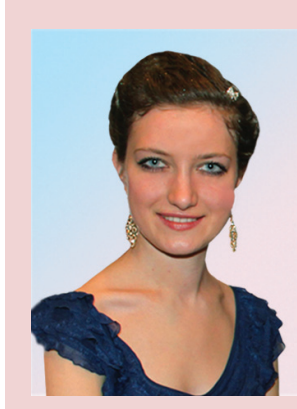

Мария Александровна

ПЕЧЕНСКАЯ

младший научный сотрудник, Федеральное государственное бюджетное учреждение науки Институт социально-экономического развития территорий Российской академии наук (160014, г. Вологда, ул. Горького, 56a, marileen@bk.ru)

Аннотация. Согласно Бюджетному кодексу бюджетный процесс в Российской Федерации включает в себя следующие стадии: составление проекта бюджета; рассмотрение и утверждение бюджета; исполнение бюджета; составление отчёта об исполнении бюджета и его утверждение. Данные стадии осуществляются в строгой последовательности и тесно взаимосвязаны между собой. Утверждённый бюджет действует в течение бюджетного периода, который в Российской Федерации составляет 12 месяцев и длится с 1 января по 31 декабря. Бюджет принимается на среднесрочный период три года. 11 декабря 2013 года депутаты Законодательного Собрания Вологодской области приняли в окончательном чтении бюджет области на 2014 год и плановый период 2015 и 2016 годов. Как отметил председатель комитета по бюджету и налогам ЗСО А.В. Канаев, проект областного бюджета сформирован в тяжелых экономических условиях, что связано с негативным влиянием значительного объёма государственного долга, необходимостью реализации майских указов Президента, а также обеспечением сбалансированности местных бюджетов. В статье дан анализ бюджетных перспектив Вологодской области на трёхлетний период. Показано, что областной бюджет на предстоящий бюджетный цикл отличается от бюджетов предыдущих лет, поскольку впервые сформирован в программной структуре расходов на основе 21 государственной программы, утверждённых Правительством области. Положительные и отрицательные черты такого нововведения ещё предстоит узнать в ходе исполнения бюджета. В статье указано, что серьёзнейшим риском для бюджетной системы региона станет прогнозируемое в 2014 году превышение предельного ограничения государственного долга относительно объёма собственных доходов на $2 \%$. Всё это произойдет на фоне напряжённых межбюджетных отношений с федеральным центром, вызванных снижением доходов (по отношению к валовому внутреннему продукту) и наращиванием дефицита федерального бюджета. Выделены основные качественные и количественные черты бюджетного цикла, в который регион вступил с 2014 года. 
Предложен комплекс мер по увеличению доходной базы регионального бюджета. Рассчитано, что осуществление предложенных мер позволит привлекать в бюджетную систему Вологодской области 9,5-13,6 млрд. рублей в год, что повысит собственные доходы, которые покроют 44\% расходов бюджета региона на социальную сферу.

Ключевые слова: областной бюджет, межбюджетные отношения, региональный долг, указы Президента, дефицит, трансферты, программный бюджет.

Pechenskaya M.A.

\section{Budgetary prospects in the region in 2014-2016: implementation of the President's social decrees or avoidance of default risks?}

Pechenskaya Mariya Aleksandrovna - Junior Research Associate, Federal State-Financed Scientific Institution the Institute of Socio-Economic Development of Territories of the Russian Academy of Sciences (56A, Gorky Sreet, Vologda, Russia, 160014, marileen@bk.ru).

Abstract. According to the Budget Code the budget process in the Russian Federation includes the following stages: drafting of a budget project; consideration and approval of the budget; budget execution; preparation of a report on the budget execution and its approval. The given stages are carried out in a strict sequence and are closely interlinked. The approved budget is in force during the budget period, which in the Russian Federation lasts 12 months from January 1 to December 31. The budget is adopted for the mediumterm period of three years. On December 11, 2013 the Vologda Oblast Legislative Assembly members adopted the oblast budget for 2014 and for the planned period of 2015 and 2016 in the final reading. According to the Chairman of the Budget and Taxation Committee of the Vologda Oblast Legislative Assembly A.V. Kanaev, the project of the oblast budget is drafted in difficult economic conditions due to a negative impact of a significant public debt, a need to implement the May Decrees of the President and provision of local budgets balance. The article analyses the Vologda Oblast budget prospects for a three-year period. It is indicated that the regional budget for the upcoming budget cycle differs from the budgets of the previous years, since it is set in the program structure of expenses on the basis of 21 state programs approved by the Oblast Government. Budget execution is to reveal advantages and disadvantages of this innovation. The article states that the most significant risk for the regional budget system is a 2014 expected excess of the threshold limit of the state debt by $2 \%$ regarding to their own revenues volume. All the described above is to happen against the background of tensed inter-budgetary relations with the Federal Centre, caused by the decrease in revenue (in relation to gross domestic product) and the federal budget deficit rise. The article singles out key qualitative and quantitative properties of the budget cycle, which the region has entered since 2014. The complex of measures to increase the regional budget revenue base is suggested. It is calculated that the proposed measures implementation is to attract 9.5-13.6 billion rubles a year in the budget system of the Vologda Oblast. Such an increase in the own revenues of the budget is to cover $44 \%$ of social overhead costs.

Key words: regional budget, inter-budgetary fiscal relations, regional debt, Presidential Decrees, deficit, transfers, programme budget. 
Ведущую роль в формировании и развитии экономической структуры любого современного общества играет государственное регулирование, осуществляемое в рамках избранной властью экономической политики. Одним из наиболее важных механизмов экономического и социального регулирования является финансовый механизм в финансовой системе. Её главным звеном выступает государственный бюджет, с помощью которого государство образует централизованные и воздействует на формирование децентрализованных фондов денежных средств, обеспечивая возможность выполнения возложенных на государственные органы функций. Неоспоримое влияние бюджета на развитие территории определяется тем, что бюджет это крупнейший фонд денежных средств, от использования которого решающим образом зависят направления развития и обеспечение устойчивости её экономики.

В последние годы наблюдается регионализация экономических процессов, проявляющаяся в передаче федеральных регулятивных функций на территориальный уровень. Это свидетельствует о расширении сферы использования региональных бюджетов и усилении их значимости. Региональные бюджеты представляют собой промежуточный уровень бюджетной системы. Поэтому, с одной стороны, они имеют самостоятельные источники формирования доходов и направления расходования средств, а с другой стороны, получают из федерального бюджета финансовую помощь и оказывают её местным бюджетам.

В соответствии с Бюджетным кодексом РФ, одним из принципов бюджетной системы выступает самостоятельность бюджета, которая может быть обеспечена только при наличии у территории собственных источников доходов и права определять направления их использования и расходования. Вот почему проблема формирования бюджета и управления бюджетным процессом на региональном уровне очень актуальна.

На протяжении последних лет формирование консолидированных бюджетов российских регионов происходило в условиях кризиса и преодоления посткризисных последствий. В связи с этим обеспечение финансовой устойчивости и стабильности доходной базы бюджета, укрепление и наращивание налогового потенциала, оптимизация расходной части бюджета являлись основными задачами региональных органов власти.

С целью обеспечения устойчивости бюджетной системы Вологодской области в 2014-2016 гг. областной бюджет основывается на консервативном сценарии социально-экономического развития. Однако это сулит торможение экономического роста в условиях стагнирующего промышленного производства, слабого роста денежных доходов населения, а следовательно, и потребительского спроса, а также спада инвестиционной активности (табл. 1).

Такая экономическая база не способна к заметному наращиванию собственных бюджетных доходов, поэтому в предстоящем бюджетном цикле вновь ожидается дефицитное исполнение бюджета, которое по прогнозам должно за три года снизиться в 2,3 раза и составить $3,6 \%$ к объёму собственных доходов (табл. 2).

И хотя прогнозные значения совокупных и собственных доходов в текущих ценах превысят докризисный уровень, можно отметить, что с учётом инфляции выйти на траекторию докризисного объёма не удастся (40,8 млрд. рублей в 2016 году против 55,9 млрд. рублей в 2008 году; рис. 1). 
Таблица 1. Основные макроэкономические показатели для составления бюджета Вологодской области на 2014-2016 годы

\begin{tabular}{|c|c|c|c|c|c|c|c|c|c|}
\hline \multirow{2}{*}{ Основные показатели } & \multicolumn{5}{|c|}{ Фактически } & \multirow{2}{*}{$\begin{array}{l}2013 \text { г., } \\
\text { оценка }\end{array}$} & \multicolumn{3}{|c|}{ Прогноз } \\
\hline & 2008 г. & 2009 г. & 2010 г. & 2011 г. & 2012 г. & & 2014 г. & 2015 г. & 2016 г. \\
\hline $\mathrm{BP}^{*}$ & 96,7 & 87,1 & 105,7 & 105,8 & 102,0 & $100,0^{*}$ & 102,7 & 102,0 & 103,5 \\
\hline $\begin{array}{l}\text { Индекс промышленного } \\
\text { производства* }\end{array}$ & 95,3 & 90,5 & 111,1 & 104,8 & 100,5 & 101,5 & 102,2 & 102,8 & 102,0 \\
\hline $\begin{array}{l}\text { Инвестиции в основной ка- } \\
\text { питал }\end{array}$ & 85,9 & 71,5 & 96,9 & 153,4 & 120,3 & 61,3 & 104,6 & 69,3 & 119,8 \\
\hline Оборот розничной торговли* & 108,5 & 89,4 & 116,3 & 106,0 & 119,7 & 103,5 & 104,8 & 105,5 & 105,0 \\
\hline $\begin{array}{l}\text { Реальные располагаемые } \\
\text { денежные доходы населения, } \\
\text { \% к предыдущему году }\end{array}$ & 98,7 & 90,4 & 108,6 & 100,2 & 111,0 & 107,6 & 102,4 & 102,4 & 104,4 \\
\hline $\begin{array}{l}\text { Индекс потребительских цен, } \\
\text { декабрь к декабрю, \% }\end{array}$ & 114,3 & 107,2 & 109,2 & 105,7 & 106,0 & $106,0^{* *}$ & $\begin{array}{c}104,5- \\
105,5^{\star *}\end{array}$ & $\begin{array}{c}104,0- \\
105,0^{* *}\end{array}$ & $\begin{array}{c}104,0- \\
105,0^{* *}\end{array}$ \\
\hline
\end{tabular}

Таблица 2. Основные параметры бюджета Вологодской области

\begin{tabular}{|c|c|c|c|c|c|c|c|c|c|}
\hline \multirow{2}{*}{ Показатели } & \multicolumn{5}{|c|}{ Фактически } & \multirow{2}{*}{$\begin{array}{c}2013 \text { г., } \\
\text { оценка }\end{array}$} & \multicolumn{3}{|c|}{ Прогноз } \\
\hline & 2008 г. & 2009 г. & 2010 г. & 2011 г. & 2012 г. & & 2014 г. & 2015 г. & 2016 г. \\
\hline Доходы, всего, млрд. руб. & 39,5 & 31,2 & 36,1 & 39,3 & 42,4 & 41,2 & 40,9 & 41,8 & 45,1 \\
\hline В \% к предыдущему году & 125,5 & 79,0 & 115,7 & 108,9 & 107,9 & 97,2 & 99,3 & 102,2 & 107,9 \\
\hline $\begin{array}{l}\text { В т.ч. налоговые и неналоговые } \\
\text { (собственные) доходы, млрд. руб. }\end{array}$ & 34,4 & 19,0 & 25,8 & 28,8 & 31,5 & 33,6 & 33,5 & 37,4 & 40,8 \\
\hline В \% к предыдущему году & 128,9 & 55,2 & 135,8 & 111,6 & 109,4 & 106,7 & 99,7 & 111,6 & 109,1 \\
\hline Расходы, всего, млрд. руб. & 39,1 & 37,7 & 43,1 & 46,5 & 45,2 & 44,7 & 44,1 & 43,9 & 46,6 \\
\hline В \% к предыдущему году & 121,0 & 96,4 & 114,3 & 107,9 & 97,2 & 98,9 & 98,7 & 99,5 & 106,2 \\
\hline Дефицит (-), профицит (+), млрд. руб. & $+0,4$ & $-6,5$ & $-7,0$ & $-7,2$ & $-2,8$ & $-3,5$ & $-3,2$ & $-2,0$ & $-1,5$ \\
\hline В \% к собственным доходам & 1,2 & $-34,2$ & $-27,1$ & $-25,0$ & $-8,9$ & $-10,4$ & $-9,6$ & $-5,4$ & $-3,6$ \\
\hline
\end{tabular}

Рисунок 1. Налоговые и неналоговые доходы областного бюджета в реальном выражении, в ценах 2016 г., млрд. руб.

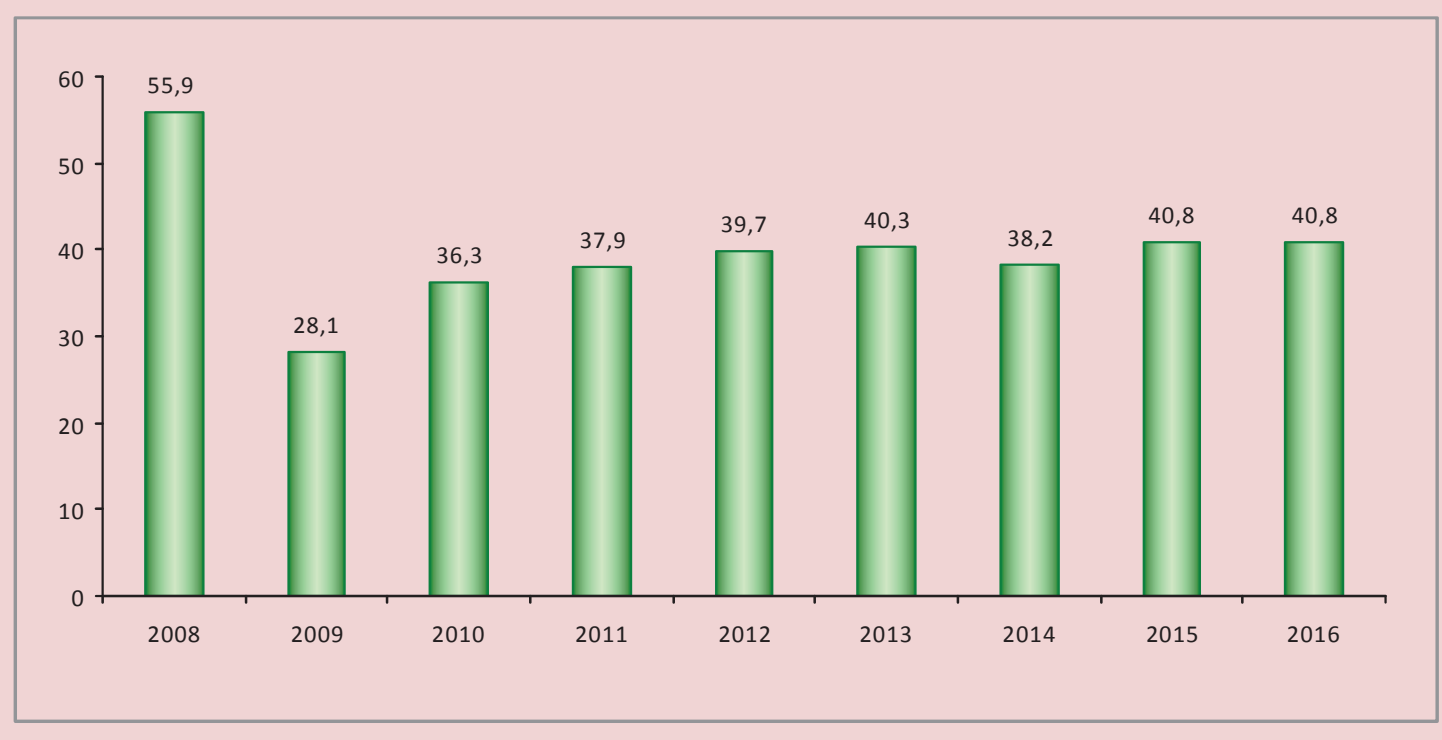


Исходя из нового бюджета региона, отметим, что налог на прибыль не сможет вернуть былое лидерство в структуре налоговых доходов (только 16\% в 2014 году против $60,5 \%$ в 2008 году).

Более того, Правительство области констатирует прогнозные нулевые поступления по данному налогу от предприятий металлургии и агрохимического холдинга. На этом фоне возрастёт значимость налога на доходы физических лиц $(38,5 \%$ собственных доходов) и имущественных налогов (26\% собственных доходов). Вместе с тем прогнозируется замедление темпов роста НДФЛ с 15,4\% в 2014 году до 9,9\% в 2016 году (против 20-26\% в докризисный период; табл. 3). В свете названных причин увеличится отставание Вологодской области по уровню заработной платы от страны в целом: с 5 тыс. рублей в 2013 году до 8,7 тыс. рублей в 2016 году (табл. 4).

Отставать от среднероссийского уровня будет в области и показатель обеспеченно- сти на душу населения налоговыми и неналоговыми доходами бюджета - разрыв увеличится с 7,4 до 17 тыс. рублей соответственно (табл. 5).

Исходя из этого, можно сделать вывод, что в предстоящие три года регион останется дотационным и продолжит взаимоотношения с федеральным бюджетом, направленные на получение дотаций с целью выравнивания бюджетной обеспеченности. Однако в новом бюджетном цикле напряжённость этих отношений усилится, что вызвано снижением доходов федерального бюджета (по отношению к ВВП) и его дефицитностью (обусловленной главным образом недопоступлением нефтегазовых налогов и несбалансированностью пенсионной системы) (табл. б). В связи с этим предусмотрено сокращение объёма межбюджетных трансфертов в региональные бюджеты (минус 6\% в 2014 году по сравнению с 2013 годом).

Таблица 3. Динамика прибыли и фонда заработной платы в Вологодской области в 2012-2016 гг.

\begin{tabular}{|c|c|c|c|c|c|}
\hline \multirow{2}{*}{ Показатели } & \multirow{2}{*}{2012 г., фракт } & \multirow{2}{*}{2013 г., оценка } & \multicolumn{3}{|c|}{ Прогно3 } \\
\hline & & & 2014 г. & $2015 \Gamma$ & 2016 г. \\
\hline Прибыль предприятий, млрд. руб. & 66,8 & 17,8 & 17,3 & 18,9 & 19,9 \\
\hline Налог на прибыль, млрд. руб. & 10,9 & 8,9 & 5,4 & 5,7 & 6,1 \\
\hline Темп роста, \% & $-9,2$ & $-18,3$ & $-39,9$ & 7,1 & 6,2 \\
\hline Фонд заработной платы, млрд. руб. & 116,1 & 126,4 & 137,8 & 150,7 & 164,4 \\
\hline Налог на доходы фризических лиц, млрд. руб. & 9,7 & 11,2 & 12,9 & 14,5 & 15,9 \\
\hline Темп роста, \% & 10,2 & 15,5 & 15,4 & 11,9 & 9,9 \\
\hline \multicolumn{6}{|c|}{$\begin{array}{l}\text { Источник: доклад Т.Б. Голыгиной «Об основных направлениях бюджетной и налоговой политики, о переходе к формированию } \\
\text { «программного» областного бюджета и подходах к формированию основных характеристик проекта консолидированного бюд- } \\
\text { жета области на } 2014 \text { год и плановый период } 2015 \text { и } 2016 \text { годов» // Официальный сайт Департамента финнансов Вологодской } \\
\text { области. }\end{array}$} \\
\hline
\end{tabular}

Таблица 4. Динамика номинальной начисленной средней заработной платы

\begin{tabular}{|c|c|c|c|c|c|c|c|c|c|}
\hline & \multicolumn{5}{|c|}{ Фактически } & \multirow{2}{*}{$\begin{array}{l}2013 \text { г., } \\
\text { оценка }\end{array}$} & \multicolumn{3}{|c|}{ Прогноз } \\
\hline & 2008 & 2009 г. & 2010 г. & 2011 г. & 2012 г. & & 2014 г. & 2015 г. & 2016 г. \\
\hline Вологодская область & 16,1 & 16,6 & 18,5 & 20,7 & 22,6 & 24,9 & 27,1 & 29,6 & 32,5 \\
\hline$P \Phi$ & 17,3 & 18,6 & 21,0 & 23,4 & 26,8 & 29,9 & 33,1 & 36,9 & 41,2 \\
\hline \multicolumn{10}{|c|}{ Разрыв в уровне средней заработной платы между Вологодской областью и РФ } \\
\hline Тыс. руб. & $-1,2$ & $-2,0$ & $-2,5$ & $-2,7$ & $-4,2$ & $-5,0$ & $-6,0$ & $-7,3$ & $-8,7$ \\
\hline$\%$ & $-6,9$ & $-10,8$ & $-11,9$ & $-11,5$ & $-15,7$ & $-16,7$ & $-18,1$ & $-19,8$ & $-21,1$ \\
\hline
\end{tabular}


Бюджетная перспектива региона 2014-2016: исполнение социальных указов Президента...

Таблица 5. Обеспеченность на душу населения налоговыми и неналоговыми доходами бюджета

\begin{tabular}{|c|c|c|c|c|c|c|c|c|c|}
\hline & \multicolumn{5}{|c|}{ Фактически } & \multirow{2}{*}{$\begin{array}{l}2013 \text { г., } \\
\text { оценка }\end{array}$} & \multicolumn{3}{|c|}{ Прогноз } \\
\hline & 2008 г. & 2009 г. & 2010 г. & 2011 г. & 2012 г. & & 2014 г. & 2015 г. & 2016 г. \\
\hline Вологодская область, тыс. руб. & 37,5 & 22,9 & 29,9 & 33,5 & 36,5 & 39,7 & 38,5 & 42,1 & 45,8 \\
\hline Российская Федерация, тыс. руб. & 34,6 & 29,9 & 34,8 & 40,8 & 36,2 & 47,1 & 52,5 & 56,9 & 62,8 \\
\hline \multicolumn{10}{|c|}{ Разрыв в уровне бюджетной обеспеченности между Вологодской областью и РФ } \\
\hline Тыс. руб. & $+2,9$ & $-7,0$ & $-4,9$ & $-7,3$ & $+0,3$ & $-7,4$ & $-14,0$ & $-14,8$ & $-17,0$ \\
\hline$\%$ & 108,4 & 76,6 & 85,9 & 82,1 & 100,8 & 84,2 & 73,4 & 74,0 & 73,0 \\
\hline $\begin{array}{l}\text { Дотация на выравнивание бюд- } \\
\text { жетной обеспеченности, млн. руб. }\end{array}$ & 0 & 0 & 0 & 737,9 & 1332,5 & 1619,4 & 1542,0 & 839,6 & 918,5 \\
\hline
\end{tabular}

Таблица 6. Основные параметры федерального бюджета и бюджетов субъектов РФ

\begin{tabular}{|c|c|c|c|c|c|c|}
\hline \multirow{2}{*}{ Параметры } & \multicolumn{2}{|c|}{ Фактически } & \multirow{2}{*}{$\begin{array}{l}2013 \text { г., } \\
\text { оценка }\end{array}$} & \multicolumn{3}{|c|}{ Прогноз } \\
\hline & 2011 г. & 2012 г. & & 2014 г. & 2015 г. & 2016 г. \\
\hline \multicolumn{7}{|c|}{ Федеральный бюджет } \\
\hline Доходы, млрд. руб. & 11368 & 12854 & 12866 & 13486 & 14768 & 15908 \\
\hline$B \% \kappa B B П$ & 20,8 & 20,5 & 19,1 & 18,2 & 18,0 & 17,4 \\
\hline Расходы, млрд. руб. & 10926 & 12891 & 13387 & 13847 & 15236 & 16452 \\
\hline$B \% \kappa B B П$ & 20,0 & 20,5 & 19,8 & 18,7 & 18,6 & 18,0 \\
\hline Десрицит/профрицит, млрд. руб. & 442 & -37 & -521 & -362 & -468 & -544 \\
\hline \multicolumn{7}{|c|}{ Бюджеты субъектов РФ } \\
\hline Доходы, млрд. руб. & 7644 & 8064 & 8593 & 9332 & 10233 & 11342 \\
\hline В \% к предыдущему году & 117,0 & 105,5 & 106,6 & 108,6 & 110,0 & 110,8 \\
\hline Межбюджетные транссрерты, млрд. руб. & 1644 & 1624 & 1394 & 1309 & 1304 & 1309 \\
\hline В \% к предыдущему году & 117,6 & 98,8 & 85,8 & 93,9 & 99,9 & 100,4 \\
\hline Расходы, млрд. руб. & 7679 & 8343 & 8787 & 9439 & 10285 & 11364 \\
\hline Десрицит, млрд. руб. & -35 & -279 & -194 & -107 & -52 & -22 \\
\hline
\end{tabular}

Снижение объёмов федеральной финансовой помощи Вологодской области и её собственных доходов из-за экономического спада ставит под угрозу финансирование реализации предвыборных президентских программ, заложенных в указах Президента РФ от 7 мая 2012 года. Дополнительная расходная нагрузка на областной бюджет в 2014-2016 гг. оценивается в размере 35,9 млрд. рублей при планируемом увеличении собственных доходов на 7,3 млрд. рублей (табл. 7). Судя по указанным оценкам, регион сможет профинансировать за счёт собственных источников 54,9\% потребности в средствах, необходимых для реализации президентских указов.
Подобная ситуация складывается и в других российских регионах России, откуда порой звучат предложения об упрощении заявленных планов и задач. На этот счёт Президент РФ Владимир Владимирович Путин в Послании Федеральному Собранию от 12.12.2013 года высказался крайне отрицательно: «...Указы обозначили конкретные меры, призванные обеспечить динамичное развитие страны во всех сферах... и стремление народа России к лучшей жизни». Глава государства отметил недопустимое затягивание проводимых преобразований (с мая 2012 года), которые ещё слабо ощущаются самими потребителями бюджетных услуг. Он призвал руководителей регионов 
Таблица 7. Информация о бюджетных ассигнованиях на реализацию в Вологодской области в 2014-2016 годах указов Президента, млн. руб.

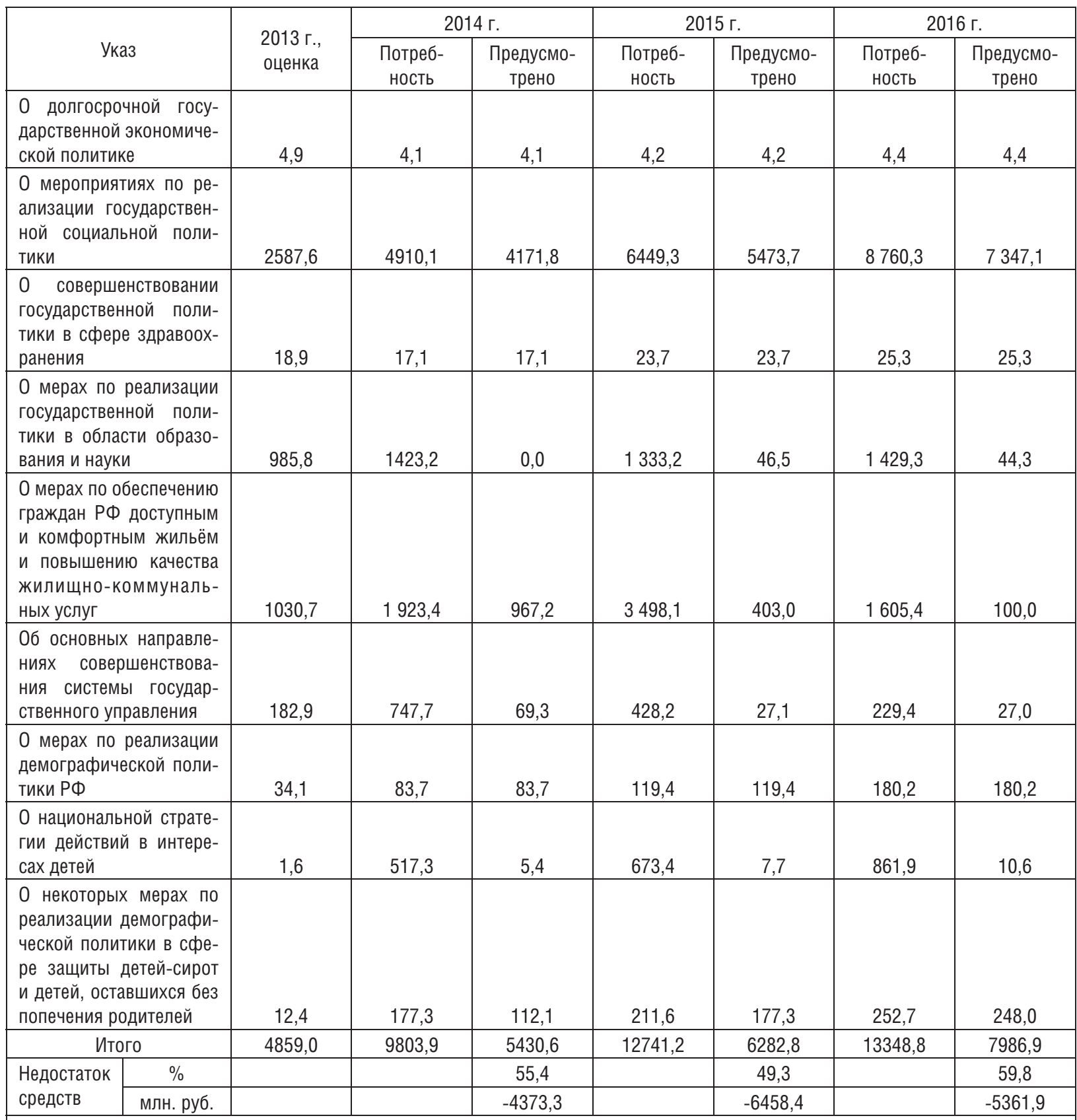

Источник: Приложение к пояснительной записке к проекту закона области «Об областном бюджете на 2014 и плановый период 2015 и 2016 годов».

активизировать в предстоящий среднесрочный период качественное исполнение указов вместо наращивания неэффективных расходов и расширения управленческого аппарата.

По-видимому, ряд вопросов социальноэкономического развития, не нашедших регионального или федерального финансового обеспечения, будет решаться за счёт роста долговой нагрузки, размер которой в области в 2013 г. оценён в 32,2 млрд. руб., что соответствует $106,5 \%$ объёма налоговых и неналоговых доходов её бюджета (табл. 8). 
Бюджетная перспектива региона 2014-2016: исполнение социальных указов Президента...

Таблица 8. Динамика государственного долга Вологодской области

\begin{tabular}{|c|c|c|c|c|c|c|c|c|c|}
\hline \multirow{2}{*}{ Показатель } & \multicolumn{5}{|c|}{ Фактически } & \multirow{2}{*}{$\begin{array}{l}2013 \text { г., } \\
\text { оценка }\end{array}$} & \multicolumn{3}{|c|}{ Прогноз } \\
\hline & 2008 г. & 2009 г. & 2010 г. & $2011 \Gamma$. & 2012 г. & & 2014 г. & 2015 г. & 2016 г. \\
\hline $\begin{array}{l}\text { Объём государственного } \\
\text { долга, млрд. руб. }\end{array}$ & 1,8 & 10,4 & 18,5 & 25,8 & 29,2 & 32,2 & 34,2 & 36,2 & 37,7 \\
\hline $\begin{array}{l}\text { В \% к собственным доходам } \\
\text { бюджета }\end{array}$ & 5,1 & 54,5 & 71,6 & 89,7 & 92,6 & 106,5 & 102,0 & 97,0 & 92,3 \\
\hline Темп прироста, \% & 3,3 & 477,8 & 77,9 & 39,5 & 13,2 & 10,3 & 8,9 & 5,8 & 4,1 \\
\hline
\end{tabular}

Таблица 9. Планируемый возврат кредитов бюджетом Вологодской области, млн. руб.

\begin{tabular}{|l|c|c|c|c|c|c|}
\hline \multirow{2}{*}{\multicolumn{1}{|c|}{ Показатели }} & \multicolumn{4}{|c|}{ Прогно3 } & $\begin{array}{c}\text { Прогно3 бюджета } \\
\text { на 2013-2015 гг. }\end{array}$ & $\begin{array}{c}\text { Прогноз бюджета } \\
\text { на 2014-2016 гг. }\end{array}$ \\
\cline { 2 - 7 } & 2014 г. & 2015 г. & 2016 г. & $2014-2016$ гг. & \multicolumn{2}{|c|}{$2014-2015$ гг. } \\
\hline Кредиты, всего & 8290 & 2172 & 8345 & 18807 & 9655 & 10462 \\
\hline - коммерческих банков & 5800 & 0 & 7465 & 13265 & 7566 & 5800 \\
\hline - фредерального бюджета & 2490 & 2172 & 880 & 5542 & 2362 & 4662 \\
\hline
\end{tabular}

Очевидно то, что в ближайшие годы Правительство Вологодской области не сможет снизить объём долговых заимствований. Более того, в 2014 г. он превысит размер собственных доходов областного бюджета на 2\%. Серьёзной нагрузкой на бюджет в предстоящем периоде станет возврат ранее предоставленных кредитов: сумма к возврату в 2 раза превысит сумму привлечённых за три года бюджетных кредитов (табл. 9).

Отсюда следует, что прогнозируемая тенденция создаст дополнительные риски для полного финансирования расходных обязательств, объём которых соответственно увеличится на 1,9 млрд. рублей. Однако в сопоставимых ценах расходы областного бюджета в 2016 году по сравнению с 2008 годом снизятся на 16,9 млрд. рублей, или 26,6\% (рuс. 2).

Качественной характеристикой предстоящего бюджетного цикла является формирование расходов областного бюджета на 2014-2016 гг. не только в функциональной, но и в программной структуре, основывающейся на утверждённых государственных программах. Если в 2013 г. было принято к реализации 6 государственных программ, то с 2014 г. их количество увеличится до 21. Расходы на реализацию государственных программ на 2014 г. составят $86,6 \%$ совокупных бюджетных расходов области, на 2015 г. - 86,3\%, на 2016 г. - 85,2\%. В свою очередь, наличие порядка 13-15\% непрограммных расходов свидетельствует о неполном обеспечении увязки расходов областного бюджета с целью и задачами государственной политики в сфере повышения эффективности управления государственными финансами.

Наиболее значимыми по объёму выделенных бюджетных ассигнований на ближайшие три года станут государственные программы, имеющие социальную направленность: развитие образования (33-34\% в сумме расходов), социальная поддержка граждан (22-23\%) и развитие здравоохранения (20\%). На сохранение и развитие сети автомобильных дорог общего пользования и обеспечение транспортного обслуживания населения будет выделено порядка $11 \%$ областных расходов (рис. 3).

В предстоящем бюджетном цикле бюджет Вологодской области сохранит социальную направленность (70\% расходов). 
Рисунок 2. Расходы бюджета Вологодской области в реальном выражении, в ценах 2016 г., млрд. руб.

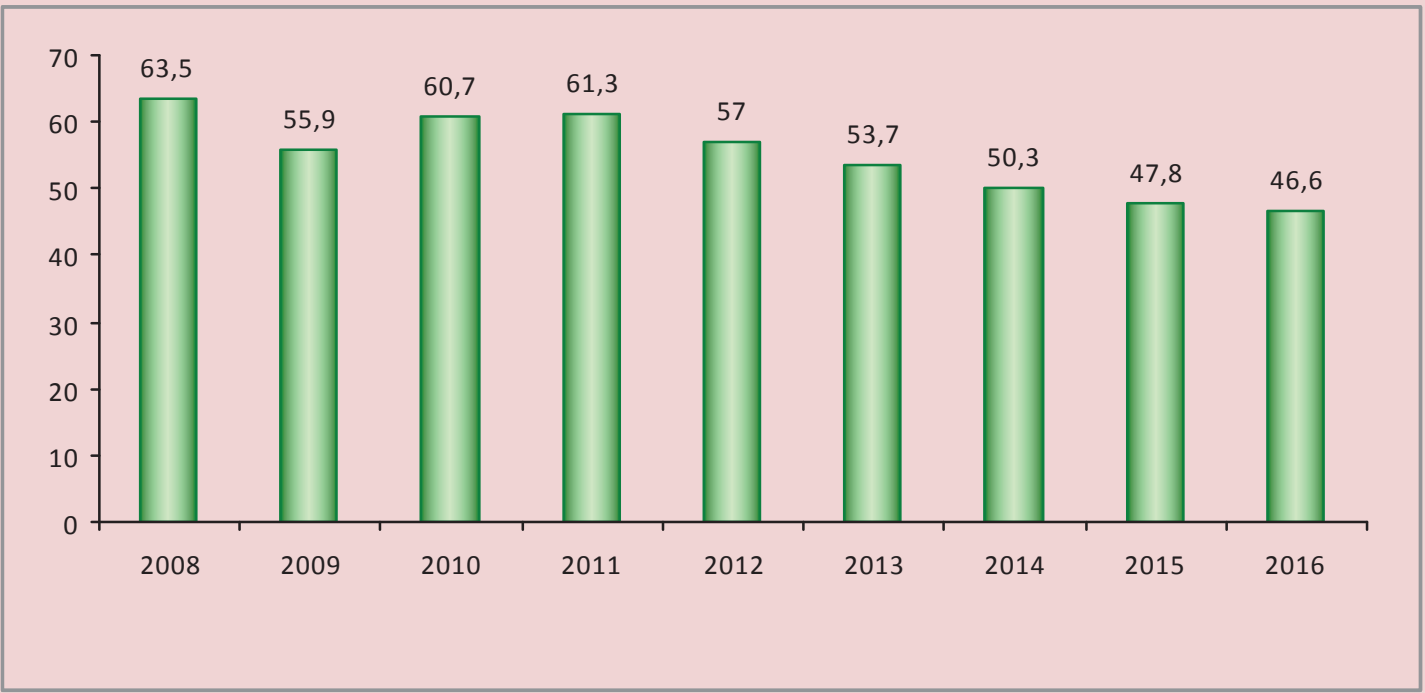

Рисунок 3. Структура расходов бюджета Вологодской области на государственные программы

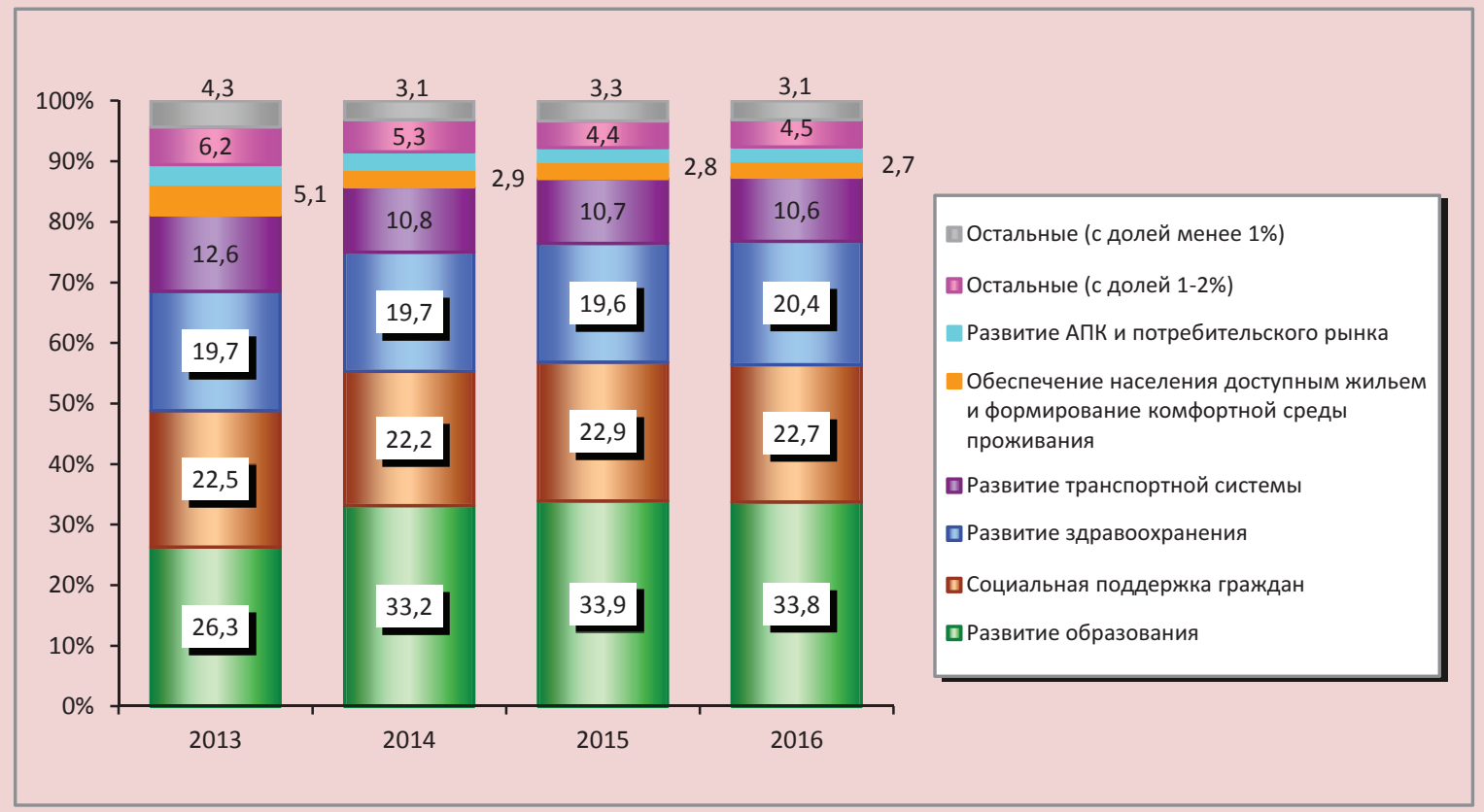

Наблюдается смена приоритетов в расходах на социальные статьи: самое масштабное финансирование областного бюджета в 2014-2016 гг. будет направляться на статью «Образование» $(28-29 \%$ расходов), которая опередит статью «Соци- альная политика» (22-23\%). На третьем месте останутся расходы на здравоохранение (17-18\%), тогда как финансирование национальной экономики будет снижаться (с 18\% в 2012-2013 гг. до 13-14\% в 20142016 гг.; табл. 10). 
Бюджетная перспектива региона 2014-2016: исполнение социальных указов Президента...

Таблица 10. Структура расходов бюджета Вологодской области в 2011-2016 гг. ${ }^{*}$

\begin{tabular}{|c|c|c|c|c|c|c|c|c|c|c|c|c|}
\hline \multirow{2}{*}{ Разделы } & \multicolumn{2}{|c|}{$\begin{array}{l}2011 \text { г., } \\
\text { фракт }\end{array}$} & \multicolumn{2}{|c|}{$\begin{array}{l}2012 \text { г., } \\
\text { факт }\end{array}$} & \multicolumn{2}{|c|}{$\begin{array}{l}2013 \text { г., } \\
\text { оценка }\end{array}$} & \multicolumn{2}{|c|}{$\begin{array}{l}2014 \text { г., } \\
\text { прогноз }\end{array}$} & \multicolumn{2}{|c|}{$\begin{array}{l}2015 \text { г., } \\
\text { прогно3 }\end{array}$} & \multicolumn{2}{|c|}{$\begin{array}{l}2016 \text { г., } \\
\text { прогноз }\end{array}$} \\
\hline & $\begin{array}{l}\text { млн. } \\
\text { руб. }\end{array}$ & $\%$ & $\begin{array}{l}\text { млн. } \\
\text { руб. }\end{array}$ & $\%$ & $\begin{array}{l}\text { млн. } \\
\text { руб. }\end{array}$ & $\%$ & $\begin{array}{l}\text { млн. } \\
\text { руб. }\end{array}$ & $\%$ & $\begin{array}{l}\text { млн. } \\
\text { руб. }\end{array}$ & $\%$ & $\begin{array}{l}\text { млн. } \\
\text { руб. }\end{array}$ & $\%$ \\
\hline Расходы, всего & 46519 & 100 & 45182 & 100 & 44756 & 100 & 44093 & 100 & 43857 & 100 & 46617 & 100 \\
\hline $\begin{array}{l}\text { Общегосударственные } \\
\text { вопросы }\end{array}$ & 2053 & 4,4 & 1836 & 4,1 & 2020,3 & 4,5 & 2150 & 4,9 & 1865 & 4,3 & 1930 & 4,1 \\
\hline $\begin{array}{l}\text { Национальная безопас- } \\
\text { ность и правоохранитель- } \\
\text { ная деятельность } \\
\end{array}$ & 2449 & 5,3 & 493 & 1,1 & 445 & 1,0 & 420 & 1,0 & 326 & 0,7 & 317 & 0,7 \\
\hline Национальная экономика & 6698 & 14,4 & 8239 & 18,2 & 8202 & 18,3 & 6280 & 14,2 & 5720 & 13,0 & 5952 & 12,8 \\
\hline$K K X^{* *}$ & 1917 & 4,1 & 1848 & 4,1 & 393 & 0,9 & 1138 & 2,6 & 605 & 1,4 & 256 & 0,5 \\
\hline Охрана окружающей среды & 236 & 0,5 & 164 & 0,4 & 145 & 0,3 & 185 & 0,4 & 149 & 0,3 & 146 & 0,3 \\
\hline Социальная сфера & 27421 & 58,9 & 30013 & 66,4 & 27651 & 61,8 & 30869 & 70,0 & 31209 & 71,2 & 32866 & 70,5 \\
\hline Образование & 7043 & 15,1 & 8285 & 18,3 & 10180 & 22,7 & 12382 & 28,1 & 12616 & 28,8 & 13238 & 28,4 \\
\hline Культура, кинематографрия & 882 & 1,9 & 594 & 1,3 & 504 & 1,1 & 477 & 1,1 & 506 & 1,2 & 594 & 1,3 \\
\hline Здравоохранение & 6643 & 14,3 & 10265 & 22,7 & 6598 & 14,7 & 7750 & 17,6 & 7726 & 17,6 & 8361 & 17,9 \\
\hline Социальная политика & 10870 & 23,4 & 10331 & 22,9 & 9924 & 22,2 & 9966 & 22,6 & 10177 & 23,2 & 10486 & 22,5 \\
\hline Физкультура и спорт & 1764 & 3,8 & 431 & 1,0 & 289 & 0,6 & 118 & 0,3 & 117 & 0,3 & 130 & 0,3 \\
\hline СМИ & 219 & 0,5 & 107 & 0,2 & 156 & 0,3 & 176 & 0,4 & 68 & 0,2 & 56 & 0,1 \\
\hline Обслуживание долга & 789 & 1,7 & 1310 & 2,9 & 1930 & 4,3 & 1919 & 4,4 & 1739 & 4,0 & 1697 & 3,6 \\
\hline
\end{tabular}

Проводимая в регионе оптимизация бюджетных расходов по-прежнему наиболее сильно отразится на таких разделах, как физкультура и спорт ${ }^{1}$, жилищно-коммунальное хозяйство ${ }^{2}$, охрана окружающей среды и национальная экономика.

Учитывая дефицитность бюджета предстоящей трёхлетки, нельзя не отметить следующие характеристики расходной части областного бюджета.

- Расходы по разделу «Общегосударственные вопросы» возрастут в 2014 году на 129,4 млн. рублей, или на $6,4 \%$. Наибольшим приростом отмечено финансирование функционирования высшего должностного лица субъекта РФ (причины

\footnotetext{
1 В связи с прекращением с 2014 г. поддержки некоммерческих организаций в сфере физической культуры и спорта.

2 В связи с уменьшением с 2014 г. и прекращением с 2016 г. софинансирования мероприятий по переселению граждан из аварийного жилищного фонда с учётом необходимости развития малоэтажного жилищного строительства.
}

этого не указаны в пояснительной записке, что снижает прозрачность бюджетного планирования).

- Ежегодно четверть расходов на национальную экономику будут составлять расходы на руководство и управление. Например, в 2014 году из 33,3 млн. рублей, предусмотренных на реализацию государственной программы «Энергоэффективность и развитие газификации», 21,6 млн. рублей, или $65 \%$, будет использовано на содержание Департамента топливно-энергетического комплекса области. Аналогично почти $60 \%$ ассигнований, выделяемых на поддержку транспорта, планируется использовать на управленческие функции.

- С 2014 года прекращается финансирование учреждений начального профессионального образования, которые в рамках реструктуризации сети планируется присоединить к учреждениям среднего профессионального образования. Но при этом 
Рисунок 4. Динамика капитальных вложений бюджета Вологодской области в 2008-2016 гг.

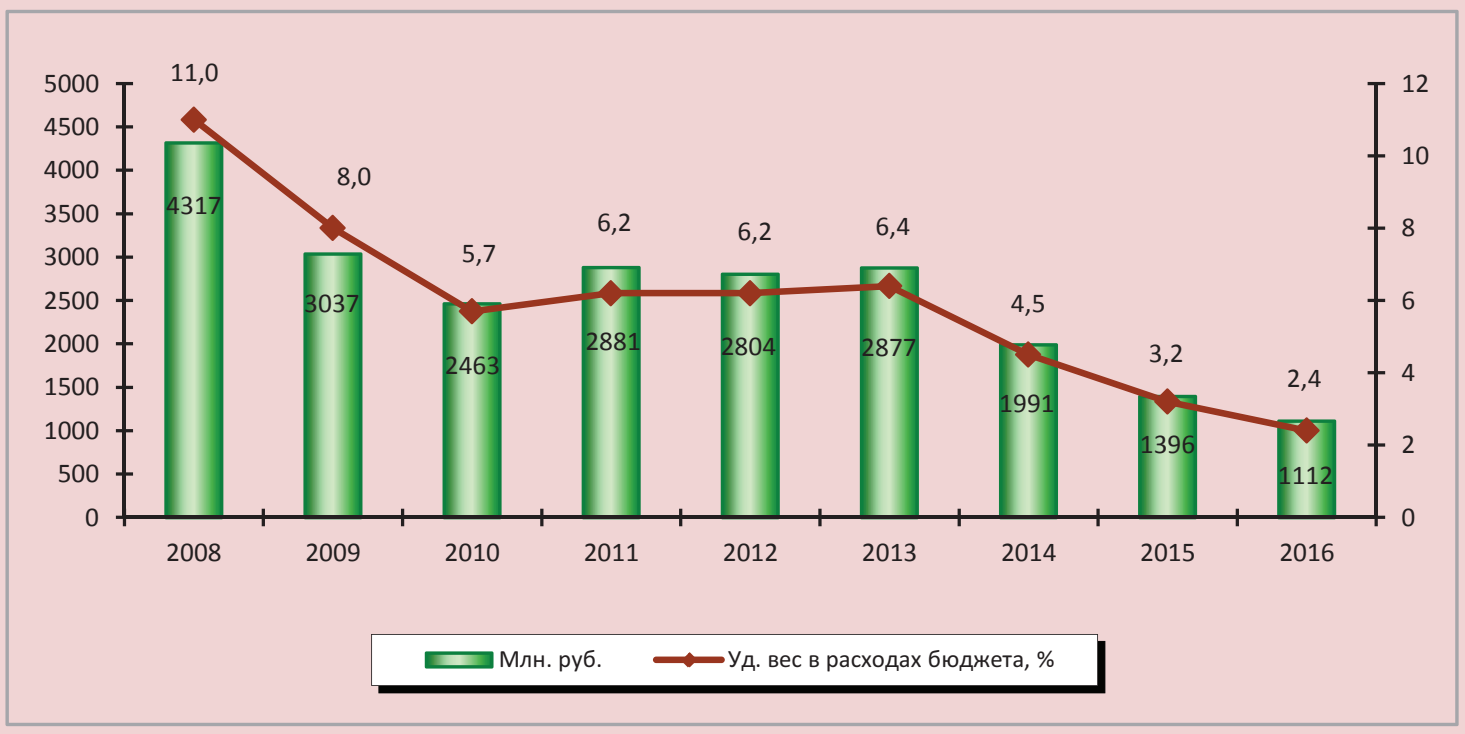

расходы по подразделу «Среднее профессиональное образование» в 2015-2016 гг. уменьшатся в 1,2 раза.

- Снизится роль регионального бюджета в финансировании культурной деятельности области: намечено сокращение расходов на культуру по сравнению с докризисным уровнем в 1,6 раза, что ставит под угрозу обеспечение в полной мере задач в сфере культуры, поставленных в Указе Президента РФ «О мероприятиях по реализации государственной социальной политики» от 07.05.2012 г. №567.

- В 2014-2016 гг. сохранится высокий уровень расходов (34-37\%) областного бюджета, связанных с необходимостью оказания безвозмездной финансовой помощи местным бюджетам³.

- Стремительно сократятся инвестиционные расходы областного бюджета: к

\footnotetext{
3 Президент России в Послании Федеральному Собранию 12.12.2013 г. предложил с 2014 года начать и законодательно обеспечить работу по уточнению общих принципов организации местного самоуправления, направленных на развитие сильной, независимой, финансово самостоятельной власти на местах.
}

2017 году они составят всего 1,1 млрд. рублей, или 2,4\% в расходах (puc. 4).

Резюмируя вышесказанное, следует выделить основные качественные и количественные черты бюджетного цикла, в который Вологодская область вступила с 2014 года:

1. Серьёзное снижение налоговых и неналоговых доходов по сравнению с докризисным уровнем в реальном выражении: в 2016 году до 73\% от уровня 2008 года.

2. Критическое падение прибыли организаций и, соответственно, поступлений от налога на прибыль в областной бюджет - до $14,9 \%$ в объёме собственных доходов в 2016 году против 17,8\% в 2009 году.

3. Замедление темпов роста поступлений от ставшего в последнее время ключевым налога на доходы физических лиц с 15,4\% в 2014 году до 9,9\% в 2016 году (против 20-26\% в докризисный период). Увеличение разрыва между показателем средней заработной платы в Вологодской области и среднероссийским уровнем - с 5 тыс. рублей в 2013 году до 8,7 тыс. рублей в 2016 году. 
4. Возникновение угрозы неисполнения указов Президента РФ, касающихся повышения заработной платы работников бюджетной сферы, обусловленное ограниченностью бюджетных ресурсов: $100 \%-$ $(54,9 \%$ собственных источников $+20 \%$ федеральных трансфертов) $=25,1 \%$ необеспеченных финансовых обязательств.

5. Предельно высокий уровень долговой нагрузки. Государственный долг, который в 2014 году составит 34,2 млрд. рублей, будет превышать объём собственных доходов бюджета на $2 \%$, что свидетельствует о неспособности региона самостоятельно погасить задолженность ${ }^{4}$.

6. Увеличение стоимости обслуживания государственного долга до 1,9 млрд. рублей.

7. Формирование $85-87 \%$ расходов бюджета в программной структуре, свидетельствующее о неполном обеспечении их увязки с задачами государственной политики, направленной на повышение эффективности управления государственными финансами.

8. Усиление напряжённости межбюджетных отношений региона с федеральным

4 На заседании фракции ЛДПР (21.10.2013 г.) в ходе обсуждения проекта федерального бюджета на 2014-2016 гг. министр финансов А.Г. Силуанов сообщил о готовящихся поправках в бюджетное законодательство, касающихся вопроса ответственной долговой политики субъектов РФ. Изменения предполагают, что, в случае если объём просроченных долговых и бюджетных обязательств региона превысит $10 \%$ от общего объёма налоговых и неналоговых доходов, губернатор должен будет заключить соглашение с Минфином о мерах по восстановлению платежеспособности и утвердить одноимённый план. Если же выполнение плана не снизит объём долга, правительство будет вправе внести Президенту предложение об отстранении губернатора от должности в связи с утратой доверия. В данном случае в субъекте Федерации вводится временная финансовая администрация. Регион теряет возможность совершать заимствования в кредитных организациях, а в условиях дефицита федерального бюджета не сможет рассчитывать на колоссальную поддержку центра в виде бюджетных кредитов, а, значит, главным последствием фактического банкротства станет невыполнение социальных обязательств. центром, которое будет проявляться в ежегодном снижении финансовой помощи регионам, что связано с заложенными в прогнозе тенденциями снижения доходов федерального бюджета и роста его дефицитности.

Таким образом, трудности исполнения федерального бюджета указывают на то, что главным источником роста доходов региональных бюджетов должны стать собственные финансовые ресурсы. Вместе с тем тенденции макроэкономических показателей не позволяют говорить об их существенном росте. Так, прибыль крупнейшего предприятия Вологодской области - ОАО «Северсталь» - в плановый период будет нулевая, а прибыль ОАО «ФосАгро-Череповец» и ЗАО «Агро-Череповец» К 2017 году снизится до 0,2 млрд. рублей. Фонд заработной платы вырастет в 1,3 раза, однако к 2017 году размер среднемесячной заработной платы в ценах 2013 года увеличится лишь в 1,1 раза 5 .

Решение системной проблемы бюджетной недостаточности Правительство Вологодской области рассматривает в большей степени с точки зрения секвестирования бюджетных расходов, а не повышения доходного потенциала территории. Как нам представляется, при формировании доходной части областного бюджета необходимо руководствоваться статьёй 32 Бюджетного кодекса РФ, учитывая все потенциальные источники доходов. Для этого требуется принять ряд мер, направленных:

- на активизацию работы по сокращению имеющейся дебиторской задолженности в бюджет;

• оптимизацию политики налогового стимулирования;

5 Из выступлений С.А. Кожевникова и В.Н. Артамоновой на публичных слушаниях по прогнозу социально-экономического развития Вологодской области и проекту закона области «Об областном бюджете на 2014 год и плановый период 2015 и 2016 годов». 
Таблица 11. Расчёт возможного увеличения поступлений в бюджетную систему региона за счёт предлагаемого совершенствования инструментов межбюджетного регулирования

\begin{tabular}{|l|c|c|c|}
\hline \multicolumn{1}{|c|}{ Мероприятие } & Фактическое значение & $\begin{array}{c}\text { Предлагаемый } \\
\text { вариант }\end{array}$ & $\begin{array}{c}\text { Дополнительные доходы, } \\
\text { млн. рублей в год }\end{array}$ \\
\hline Снижение недоимки по платежам в бюджет & $13,5-18 \%$ & 0 & $5400-6300$ \\
\hline $\begin{array}{l}\text { Ликвидация несинансируемых федеральных } \\
\text { льгот }\end{array}$ & $\begin{array}{c}55-69 \% \text { исчисленной } \\
\text { суммы в бюджет }\end{array}$ & 0 & $212-457$ \\
\hline $\begin{array}{l}\text { Обеспечение полноты использования целевых } \\
\text { транссрертов }\end{array}$ & $\begin{array}{c}2-5 \% \text { суммы } \\
\text { трансфертов }\end{array}$ & 0 & $191-194$ \\
\hline Повышение ставки налога на дивиденды & $9 \%$ & $15 \%$ & $12-55$ \\
\hline $\begin{array}{l}\text { Совершенствование управления остатками } \\
\text { бюджетных средств }\end{array}$ & 0 & \% по депозитам & $5-69$ \\
\hline $\begin{array}{l}\text { Обеспечение полного фринансирования деле- } \\
\text { гированных полномочий }\end{array}$ & $95-99 \%$ & $100 \%$ & $9471-13582$ \\
\hline Итого & & \\
\hline * Расчёты проведены нами в рамках периода 2010-2012 гг. & \\
\hline
\end{tabular}

- обеспечение полноты использования целевых трансфертов;

- совершенствование порядка налогообложения доходов физических лиц;

- повышение эффективности управления остатками бюджетных средств;

- обеспечение полного финансирования делегированных полномочий.

По нашим расчётам, осуществление обозначенных мер позволит привлекать в бюджетную систему Вологодской области 9,5-13,6 млрд. рублей в год, что повысит объём собственных доходов, которые покроют 44\% расходов бюджета на социальную сферу (табл. 11).

В качестве заключения отметим, что в реальности исполнение бюджета нередко бывает далёким от прогнозных параметров. Отсюда первичной в системе управления бюджетом становится проблема качества бюджетного планирования на региональном уровне. Без его значительного улучшения будет трудно осуществить увязку исполнения программного бюджета с решением стратегических задач территориального развития. Низкий уровень прогнозов, которые закладываются в основу бюджетных проектировок, приводит к систематическим пересмотрам бюджета на текущий год (бюджет на 2013 год пересматривался 5 раз). При этом составление бюджета на трёхлетний период теряет смысл. Тем более что при исполнении областного бюджета сложилась практика недофинансирования утверждённых расходных обязательств. Это ставит бюджетополучателей в сложное положение и дезорганизует функционирование соответствующих секторов экономики. Представляется, что назрела необходимость как повышения персональной ответственности за качество подготовки проекта бюджета и его исполнение, так и законодательного установления порога допустимых изменений и бюджета в целом, и его структурных разделов, а также целевых программ.

\section{Литература}

1. Артамонова, В.Н. Об изменении механизма межбюджетного регулирования в Вологодской области: доклад на совещании с главами муниципальных районов 10.10.2013 г. / В.Н. Артамонова // Официальный сайт Департамента финансов Вологодской области. - Режим доступа: http://www.df35.ru /images/file/news/10.10.2013/Prezentazia_Artamonova_10102013.pdf

2. Бурлачков, В.К. Координация бюджетной и денежно-кредитной политики: опыт ведущих стран и его использование в России / В.К. Бурлачков // Вестник Российского экономического университета имени Г.В. Плеханова. - 2012. - №10(52). - С. 20-26. 
3. Заключение Счетной палаты Российской Федерации на проект Федерального закона «О федеральном бюджете на 2014 год и на плановый период 2015 и 2016 годов» // Официальный сайт Счётной палаты РФ. - Режим доступа: http://www.ach.gov.ru/ru/expert/before/?id=1071

4. Ильин, В.А. Проблемы исполнения территориальных бюджетов в 2011 году / В.А. Ильин, А.И. Поварова // Экономика. Налоги. Право. - 2012. - №5. - С. 87.

5. Материалы официального сайта депутата Государственной Думы РФ О.Г. Дмитриевой. - Режим доступа: http://www.dmitrieva.org/

6. Об исполнении бюджетов субъектов РФ и местных бюджетов за 2003-2013 гг:: отчётность Казначейства России // Официальный сайт Федерального казначейства. - Режим доступа: http://www.roskazna.ru/ reports/mb.html

7. О бюджетной политике в 2014-2016 годах: бюджетное Послание Президента РФ Федеральному Собранию // Официальный сайт Президента РФ. - Режим доступа: http://www.kremlin.ru/

8. Об областном бюджете на 2011-2013 гг., 2012-2014 гг., 2013-2015 гг., 2014-2016 гг.: законы Вологодской области // КонсультантПлюс: справочно-поисковая система.

9. О федеральном бюджете на 2014 год и на плановый период 2015 и 2016 годов: Федеральный закон от 02.12.2013 №349-Ф3 [Электронный ресурс]. - Режим доступа: http://www.minfin.ru/common/upload/ library/2013/12/main/FZ349-FZ_ot_021213.pdf

10. О формировании проекта бюджета на 2014 год и плановый период 2015-2016 годов: материалы совещания с руководителями финансовых органов муниципальных районов, городских округов и сельских поселений Вологодской области 03.09.2013 г. // Официальный сайт Департамента финансов Вологодской области. - Режим доступа: http://www.df35.ru/index.php?option=com_content\&view=article\& id=1835:2013-09-03-13-02-38\&catid=34:demo-content $\&$ Itemid $=134$

11. Печенская, М.А. Актуальные вопросы совершенствования межбюджетных отношений в системе местного самоуправления / М.А. Печенская, Т.В. Ускова // Экономические и социальные перемены: факты, тенденции, прогноз. - 2012. - №1(19). - С. 136-146.

12. Печенская, М.А. Проблемы совершенствования межбюджетных отношений региона и федерального центра / М.А. Печенская // Экономические и социальные перемены: факты, тенденции, прогноз. 2012. - №6. - C. 173-182.

13. Печенская, М.А. Состояние бюджетов муниципальных образований и направления эффективного использования их собственных доходных источников [Текст] / М.А. Печенская // Проблемы развития территории. - 2012. - №60. - С. 83-96.

14. Печенская, М.А. Регион и федеральный центр: состояние и оценка результативности бюджетных отношений / М.А. Печенская // Аудит и финансовый анализ. - 2013. - №5. - С. 397-404.

15. Печенская, М.А. Проблемы бюджетной обеспеченности региона и направления повышения её уровня / М.А. Печенская // Известия высших учебных заведений (Серия «Экономика, финансы и управление производством»). - 2013. - №3(17). - С. 25-33.

16. Поварова, А.И. Трёхлетний бюджет: ждать ли стабильности? / А.И. Поварова // Экономические и социальные перемены: факты, тенденции, прогноз. - 2011. - №2. - С. 20.

17. Поварова, А.И. Областной бюджет 2012: стабилизация откладывается / А.И. Поварова // Экономические и социальные перемены: факты, тенденции, прогноз. - 2012. - № 3. - С. 39.

18. Послание Президента Федеральному Собранию 12.12.2013 г. // Официальный сайт Президента РФ. Режим доступа: http://www.kremlin.ru/

19. Послание Губернатора Вологодской области Законодательному Собранию области 30.10.2013 г. // Официальный сайт Губернатора Вологодской области. - Режим доступа: http://okuvshinnikov.ru/ interview/byudzhetnoe_poslanie_gubernatora_oblasti_na_sessii_zakonodatelnogo_sobraniya_oblasti_30_ oktyabrya_2013_goda/

20. Прогноз социально-экономического развития РФ на 2014 год и на плановый период 2015 и 2016 годов // Официальный сайт Министерства экономического развития РФ. - Режим доступа: http://www. economy.gov.ru/wps/wcm/connect/economylib4/mer/activity/sections/macro/prognoz/doc20130924_5

21. Раздаточные материалы к публичным слушаниям по прогнозу социально-экономического развития Вологодской области и проекту закона области «Об областном бюджете на 2014 год и плановый период 2015 и 2016 годов».

22. Регионы России. Основные характеристики субъектов РФ [Электронный ресурс]// Федеральная служба государственной статистики. - Режим доступа: http://www.gks.ru/wps/wcm/connect/rosstat_main/rosstat/ ru/statistics/publications/catalog/doc_1138625359016 


\section{References}

1. Artamonova V.N. Ob izmenenii mekhanizma mezhbyudzhetnogo regulirovaniya v Vologodskoy oblasti: doklad na soveshchanii s glavami munitsipal'nykh rayonov 10.10.2013 g. [About the Change in the Mechanism of InterBudget Regulation in the Vologda Oblast: Report at the Meeting with Heads of Municipal Districts, October 10, 2013]. Ofitsial'nyy sayt Departamenta finansov Vologodskoy oblasti [Official Website of the Department of Finance of the Vologda Oblast]. Available at: http://www.df35.ru/images/file/news/10.10.2013/Prezentazia_ Artamonova_10102013.pdf

2. Burlachkov V.K. Koordinatsiya byudzhetnoy i denezhno-kreditnoy politiki: opyt vedushchikh stran i ego ispol'zovanie v Rossii [Coordination of Fiscal and Monetary Policy: the Experience of Leading Countries and Its Use in Russia] Vestnik Rossiyskogo ekonomicheskogo universiteta imeni G. V. Plekhanova [Bulletin of Plekhanov Russian University of Economics], 2012, no.10(52), pp. 20-26.

3. Zaklyuchenie Schetnoy palaty Rossiyskoy Federatsii na proekt Federal'nogo zakona “O federal'nom byudzhete na 2014 god i na planovyy period 2015 i 2016 godov" [The Opinion of the Accounts Chamber of the Russian Federation on the Draft Federal Law "On the Federal Budget for the Year 2014 and for the Planned Period of 2015 and 2016"]. Ofitsial'nyy sayt Schetnoy palaty RF [Official Website of the RF Accounts Chamber]. Available at: http://www.ach.gov.ru/ru/expert/before/?id=1071

4. Ilyin V.A., Povarova A.I. Problemy ispolneniya territorial'nykh byudzhetov v 2011 godu [Problems of Execution of Territorial Budgets in 2011]. Ekonomika. Nalogi. Pravo [Economics. Taxes. Law], 2012, no.5, p. 87.

5. Materialy ofitsial'nogo sayta deputata Gosudarstvennoy Dumy RF O.G. Dmitrievoy [Materials of the Official Website of O.G. Dmitrieva, the Deputy of the Russian Federation State Duma]. Available at: http://www.dmitrieva.org/

6. Ob ispolnenii byudzhetov sub"ektov RF i mestnykh byudzhetov za 2003-2013 gg.: otchetnost' Kaznacheystva Rossii [On Execution of Budgets of the RF Subjects and Local Budgets for 2003-2013: Statements of the Treasury of Russia]. Ofitsial'nyy sayt Federal'nogo kaznacheystva [Official Website of the Federal Treasury]. Available at: http://www.roskazna.ru/reports/mb.html

7. O byudzhetnoy politike v 2014-2016 godakh: byudzhetnoe Poslanie Prezidenta RF Federal'nomu Sobraniyu [On the Budgetary Policy in 2014-2016: Budget Message of the RF President to the Federal Assembly]. Ofitsial'nyy sayt Prezidenta RF [Official Website of the RF President]. Available at: http://www.kremlin.ru/

8. Ob oblastnom byudzhete na 2011-2013 gg., 2012-2014 gg., 2013-2015 gg., 2014-2016 gg.: zakony Vologodskoy oblasti [About the Oblast Budget for 2011-2013, 2012-2014, 2013-2015, 2014-2016: Laws of the Vologda Oblast]. Konsul'tantPlyus: spravochno-poiskovaya sistema [ConsultantPlus: Reference-Search System].

9. O federal'nom byudzhete na 2014 god i na planovyy period 2015 i 2016 godov: Federal'nyy zakon ot 02.12.2013 №349-FZ [On the Federal Budget for 2014 and for the Planned Period of 2015 and 2016: Federal Law of December 02, 2013 No.349-FZ]. Available at: http://www.minfin.ru/common/upload/library/2013/12/main/FZ349-FZ_ ot_021213.pdf

10. O formirovanii proekta byudzheta na 2014 god i planovyy period 2015-2016 godov: materialy soveshchaniya s rukovoditelyami finansovykh organov munitsipal'nykh rayonov, gorodskikh okrugov i sel'skikh poseleniy Vologodskoy oblasti 03.09.2013 g. [About the Formation of the Budget for 2014 and for the Planned Period of 2015-2016: Proceedings of the Meeting with Heads of Financial Bodies of Municipal Districts, Urban Districts and Rural Settlements in the Vologda Oblast, September 03, 2013]. Ofitsial'nyy sayt Departamenta finansov Vologodskoy oblasti [Official Website of the Department of Finance of the Vologda Oblast]. Available at: http:// www.df35.ru/index.php?option=com_content\&view=article\&id=1835:2013-09-03-13-02-38\&catid=34:democontent\&Itemid $=134$

11. Pechenskaya M.A., Uskova T.V. Aktual'nye voprosy sovershenstvovaniya mezhbyudzhetnykh otnosheniy v sisteme mestnogo samoupravleniya [Topical Issues of the Improvement of Intergovernmental Dealings in the System of Local Government]. Ekonomicheskie i sotsial'nye peremeny: fakty, tendentsii, prognoz [Economic and Social Changes: Facts, Trends, Forecast], 2012, no.1(19), pp. 136-146.

12. Pechenskaya M.A. Problemy sovershenstvovaniya mezhbyudzhetnykh otno-sheniy regiona i federal'nogo tsentra [Issues of Improving Inter-Budget Relations between the Region and the Federal Centre]. Ekonomicheskie $i$ sotsial'nye peremeny: fakty, tendentsii, prognoz [Economic and Social Changes: Facts, Trends, Forecast], 2012, no.6, pp. 173-182.

13. Pechenskaya M.A. Sostoyanie byudzhetov munitsipal'nykh obrazovaniy i napravleniya effektivnogo ispol'zovaniya ikh sobstvennykh dokhodnykh istochnikov [State of Municipal Budgets and Directions of the Effective Use of their Own Revenue Sources]. Problemy razvitiya territorii [Problems of Development of Territories], 2012, no. 60 , pp. 83-96. 
14. Pechenskaya M.A. Region i federal'nyy tsentr: sostoyanie i otsenka re-zul'tativnosti byudzhetnykh otnosheniy [A Region and the Federal Centre: State and Efficiency Assessment of Intergovernmental Fiscal Relations]. Audit i finansovyy analiz [Audit and Financial Analysis], 2013, no.5, pp. 397-404.

15. Pechenskaya M.A. Problemy byudzhetnoy obespechennosti regiona i napravleniya povysheniya ee urovnya [Problems of Budgetary Sufficiency of the Region and Ways of Increasing Its Level]. Izvestiya vysshikh uchebnykh zavedeniy (Seriya “Ekonomika, finansy i upravlenie proizvodstvom”) [Proceedings of Higher Schools (Series "Economics, Finance and Production Management"], 2013, no.3(17), pp. 25-33.

16. Povarova A.I. Trekhletniy byudzhet: zhdat' li stabil'nosti? [The Three-Year Budget: Should We Wait for Stability?]. Ekonomicheskie i sotsial'nye peremeny: fakty, tendentsii, prognoz [Economic and Social Changes: Facts, Trends, Forecast], 2011, no.2, p. 20.

17. Povarova A.I. Oblastnoy byudzhet 2012: stabilizatsiya otkladyvaetsya [Regional Budget of 2012 - 2014: Stability Is Delayed]. Ekonomicheskie i sotsial'nye peremeny: fakty, tendentsii, prognoz. [Economic and Social Changes: Facts, Trends, Forecast], 2012, no.3, p. 39.

18. Poslanie Prezidenta Federal'nomu Sobraniyu 12.12.2013 g. [Presidential Address to the Federal Assembly, December 12, 2013]. Ofitsial'nyy sayt Prezidenta RF [Official Website of the RF President]. Available at: http:// www.kremlin.ru/

19. Poslanie Gubernatora Vologodskoy oblasti Zakonodatel'nomu Sobraniyu oblasti 30.10.2013 g. [Address of the Vologda Oblast Governor to the Legislative Assembly of the Oblast, October 30, 2013]. Ofitsial'nyy sayt Gubernatora Vologodskoy oblasti [Official Website of the Vologda Oblast Governor]. Available at: http://okuvshinnikov.ru/ interview/byudzhetnoe_poslanie_gubernatora_oblasti_na_sessii_zakonodatelnogo_sobraniya_oblasti_30_ oktyabrya_2013_goda/

20. Prognoz sotsial'no-ekonomicheskogo razvitiya RF na 2014 god i na planovyy period 2015 i 2016 godov [Forecast of Socio-Economic Development of the Russian Federation for the year 2014 and for the Planned Period of 2015 and 2016]. Ofitsial'nyy sayt Ministerstva ekonomicheskogo razvitiya RF [Official Website of the Ministry of Economic Development of the Russian Federation]. Available at: http://www.economy.gov.ru/wps/wcm/connect/ economylib4/mer/activity/sections/macro/prognoz/doc20130924_5

21. Razdatochnye materialy k publichnym slushaniyam po prognozu sotsial'no-ekonomicheskogo razvitiya Vologodskoy oblasti i proektu zakona oblasti “Ob oblastnom byudzhete na 2014 god i planovyy period 2015 i 2016 godov" [Handouts for the Public Hearings on the Forecast of Socio-Economic Development of the Vologda Oblast and the Draft Oblast Law "On the Oblast Budget for the Year 2014 and for the Planned Period of 2015 and 2016].

22. Regiony Rossii. Osnovnye kharakteristiki sub"ektov RF [Regions of Russia. Main Characteristics of the RF Subjects]. Federal'naya sluzhba gosudarstvennoy statistiki [Federal State Statistics Service]. Available at: http:// www.gks.ru/wps/wcm/connect/rosstat_main/rosstat/ru/statistics/publications/catalog/doc_1138625359016 


\section{ИННОВАЦИОННОЕ РАЗВИТИЕ}

УДК 339.9(470.12), ББК 65.59(2Рос-4Вол)

(С) Теребова С.В., Кузьмин И.В.

\section{Седьмая рамочная программа ЕC: возможности для российских академических учреждений *}

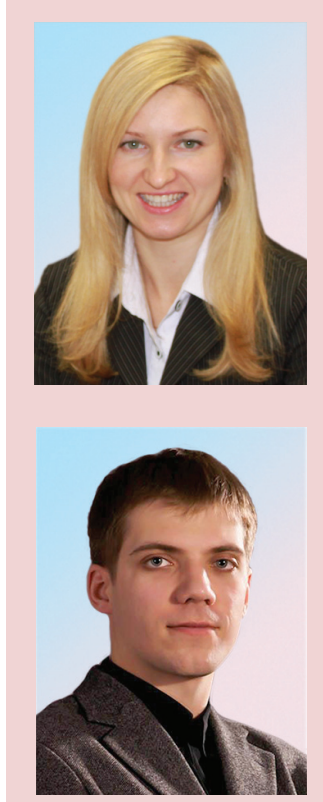

\section{Светлана Викторовна ТЕРЕБОВА}

кандидат экономических наук, зав. отделом, Федеральное государственное бюджетное учреждение науки Институт социально-экономического развития территорий Российской академии наук (160014, Россия, г. Вологда, ул. Горького, д. 56a, svetlana-ter@mail.ru)

\section{Илья Владимирович КУЗЬМИН}

младший научный сотрудник, Федеральное государственное бюджетное учреждение науки Институт социально-экономического развития территорий Российской академии наук (160014, Россия, г. Вологда, ул. Горького, д. 56а, honorarium@mail.ru)

Аннотация. Статья посвящена вопросам расширения международного сотрудничества в сфере инновационной деятельности. Рассмотрен один из ключевых инструментов его развития - Седьмая рамочная программа ЕС (7РП). Выполнен анализ статистической информации, отражающей степень вовлечённости российских организаций в работу по проектам тематического направления «Социально-экономические и гуманитарные науки» 7РП. Представлен опыт участия Института социально-экономического развития территорий РАН в конкурсах данной программы, в т. ч. в проекте «Социальные инновации: фактор изменений в обществе». Раскрыта сущность социальных инноваций, выделены их особенности, дана классификация.

Ключевые слова: международное сотрудничество, инновационная деятельность, Седьмая рамочная программа ЕС, социальные инновации.

\footnotetext{
* Работа выполнена при поддержке Российского фонда фундаментальных исследований (грант № 12-06-00379-а).
} 
Terebova S.V., Kuzmin I.V.

\section{The EU's Seventh Framework Programme: opportunities for Russian academic institutions}

Terebova Svetlana Viktorovna - Ph.D. in Economics, Department Head, Federal State-Financed Scientific Institution the Institute of Socio-Economic Development of Territories of the Russian Academy of Sciences (56A, Gorky Street, Vologda, 160014, Russia, svetlana-ter@mail.ru)

Kuzmin Ilya Vladimirovich - Junior Research Associate, Federal State-Financed Scientific Institution the Institute of Socio-Economic Development of Territories of the Russian Academy of Sciences (56A, Gorky Street, Vologda, 160014, Russia, honorarium@mail.ru)

Abstract. The article deals with the issues concerning the expansion of international cooperation in the sphere of innovation activity. The authors consider one of the main tools of its develop-ment - the EU's Seventh Framework Programme (FP7). The article presents the analysis of sta-tistical information reflecting the degree of involvement of Russian organizations in the work on the projects in the subject area "Socio-Economic Sciences and Humanities" under FP7. The au-thors present the experience of participation of the Institute of Socio-Economic Development of Territories of RAS in the competitions under this program, including the project "Social Innova-tion: a Factor in the Changes in Society". The article reveals the essence of social innovations, highlights their features, and gives their classification.

Key words: international cooperation, innovation activity, EU's Seventh Framework Programme, social innovations.

Переход России к новой экономической системе сопровождался наличием весьма обширного спектра проблем во всех сферах жизни общества. Несмотря на то что первый этап становления рыночной экономики пройден, сопровождавшие его трудности продолжают существовать. Можно говорить о создании базиса для дальнейшего развития страны, которое невозможно без увеличения человеческого капитала, повышения качества жизни населения. Важным, однако не разработанным на сегодняшний день аспектом теоретико-методологических подходов к изучению вопросов повышения качества жизни становится освоение социальных инноваций, в частности путём вовлечения населения в общественные инновационные проекты, реализуемые на основе частно-государственного партнёрства, ведущие к усилению социальной консо- лидации и направленные на достижение сглаживания последствий избыточного неравенства в обществе.

Как нам представляется, необходимо, чтобы разработке и внедрению социальных инноваций предшествовало всестороннее изучение процессов их возникновения и развития, а также грамотное построение стратегии их освоения. Причём сформированная стратегия тем надёжнее, чем обширнее теоретический и практический материал, заложенный в её основу. Что касается практического аспекта, то социальные инновации в ряде развитых государств (Западной Европы, Скандинавии) целенаправленно внедряются уже на протяжении нескольких десятилетий.

Благодаря научным исследованиям, выполняемым при поддержке Российского фонда фундаментальных исследований Институтом социально-экономического 
развития территорий РАН (ИСЭРТ РАН), в нем разрабатываются теоретико-методологические основы изучения социальных инноваций. Этот опыт позволил ИСЭРТ РАН принять участие в крупном международном научно-исследовательском проекте по рассматриваемой проблематике.

Следует также отметить, что, хотя научные организации ряда стран проводят теоретические исследования в данной области, сущность явления «социальные инновации», экономические, иные условия их возникновения изучены в недостаточной степени. Авторами теоретических концепций выступают, как правило, зарубежные исследователи. Однако даже в их трудах неразработанными остаются, в частности: вопросы о различиях между социальными инновациями, основанными на технологиях, и нетехнологическими социальными инновациями; причинах, стимулирующих и тормозящих их появление; взаимодействии органов власти и управления, предприятий, общественных организаций, «целевой аудитории» разрабатываемых инициатив для создания успешных социально-инновационных проектов.

Таким образом, закономерным представляется вывод о том, что катализатором роста научно-практических знаний о процессах развития социальных инноваций способны выступить обмен опытом, осуществляемый исследователями на межнациональном уровне, объединение их усилий в изучении поднимаемых проблем, в т. ч. проведение совместных научно-исследовательских работ. В рамках последних могут быть рассмотрены специфические особенности разрабатываемых научных положений и практических рекомендаций на примерах различных регионов мира.

Одним из основных инструментов, создающих возможности для возникновения соответствующих практик, развития международного сотрудничества в инновационной деятельности, в Европе являются программы поддержки научных исследований.

Ключевое место в ряде данных программ занимают так называемые рамочные программы Европейского союза по развитию научных исследований и технологий. Главная цель этих программ заключается в осуществлении финансирования НИОКР в целях создания и развития Европейского научно-исследовательского пространства (ЕНИП). Программы последовательно сменяют друг друга, реализация каждой последующей осуществляется в течение нескольких лет и направлена на достижение конкретных целей очередного этапа формирования ЕНИП.

Первая рамочная программа ЕС была реализована в период 1984-1988 гг., в настоящий момент заканчивается Седьмая (7РП), рассчитанная на 2007-2013 гг. Общий бюджет размером около 53,2 млрд. евро делает её одной из крупнейших в мире инициатив в поддержке научных исследований.

Успешность функционирования данного инструмента развития научных исследований и технологий приводила к значительному увеличению бюджета каждого последующего этапа. Можно заключить, что в оценках Европейской комиссии вопросы инновационного сотрудничества приобретают всё большую актуальность, поскольку бюджет Седьмой рамочной программы в разы превышает бюджет Первой (табл. 1).

За пять лет количество участников научно-исследовательских проектов, финансируемых из бюджета программы, составило более 82 тыс. организаций (табл. 2). 
Таблица 1. Бюджеты рамочных программ Европейского союза по развитию научных исследований и технологий, млрд. евро

\begin{tabular}{|l|c|c|}
\hline \multicolumn{1}{|c|}{ Рамочная программа } & Период действия & Бюджет \\
\hline Первая & $1984-1988$ & 3,75 \\
\hline Вторая & $1987-1991$ & 5,40 \\
\hline Третья & $1990-1994$ & 6,60 \\
\hline Четвёртая & $1994-1998$ & 13,22 \\
\hline Пятая & $1998-2002$ & 14,96 \\
\hline Шестая & $2002-2006$ & 17,88 \\
\hline Седьмая & $2007-2013$ & 50,52 \\
\hline Источник: Artis M.J., Nixson F. The Economics of the European Union: Policy and Analysis - 4th ed. - Oxford University Press, 2007. \\
\hline
\end{tabular}

Таблица 2. Результаты Седьмой рамочной программы ЕС за 2007-2011 гг.

\begin{tabular}{|l|c|c|c|c|c|c|}
\hline \multirow{2}{*}{ Показатель } & \multicolumn{7}{c|}{ Год } \\
\cline { 2 - 7 } & 2007 & 2008 & 2009 & 2010 & 2011 & Итого \\
\hline Количество поддержанных проектов & 3132 & 2720 & 4037 & 3399 & 2813 & $\mathbf{1 6 1 0 1}$ \\
\hline $\begin{array}{l}\text { Количество участвовавших органи- } \\
\text { заций }\end{array}$ & 22077 & 14112 & 19471 & 13710 & 12932 & - \\
\hline Общее фринансирование, млрд. евро & 6,52 & 4,43 & 5,66 & 5,31 & 3,69 & $\mathbf{2 5 , 6 0}$ \\
\hline $\begin{array}{l}\text { Средний объём фринансирования } \\
\text { проекта, тыс. евро }\end{array}$ & 2080,19 & 1629,34 & 1401,65 & 1561,35 & 1310,42 & $\mathbf{1 5 8 9 , 8 8}$ \\
\hline $\begin{array}{l}\text { Средний объём фринансирования } \\
\text { организации, тыс. евро }\end{array}$ & 295,11 & 314,05 & 290,61 & 387,09 & 285,05 & - \\
\hline
\end{tabular}

Источник: Fifth FP7 Monitoring Report. Monitoring Report 2011 [Электронный ресурс]. - Режим доступа: http://ec.europa.eu/research/ evaluations/index_en.cfm?pg=fp7-monitoring

Главным преимуществом участия в 7РП представляется получение финансирования на выполнение большей части собственных НИОКР.

В то же время в ходе реализации поддержанного проекта 7РП организация получает возможность:

- выхода на зарубежные рынки с наукоёмким продуктом;

- обмена опытом с иностранными партнёрами, работающими в смежных областях;

- повышения квалификации сотрудников;

- привлечения интереса и средств других спонсоров;

- существенного укрепления репутации и повышения известности.

Наибольший интерес для инновационных предприятий представляет специаль- ная подпрограмма 7РП «Сотрудничество», поскольку именно она направлена на поддержку совместных НИОКР предприятий (в том числе малых и средних), университетов, научно-исследовательских организаций разных стран мира. Бюджет подпрограммы «Сотрудничество» составляет 39 млрд. евро - более половины общего бюджета 7РП. Как одно из её приоритетных тематических направлений выделены «Социально-экономические и гуманитарные науки». Объём финансирования данного направления в рамках 7РП составляет 600 млн. евро, что соответствует доле в размере около $2 \%$ в структуре бюджета программы (рuс. 1).

За 2007-2012 гг. финансирование проектов по направлению «Социально-экономические и гуманитарные науки» возросло на $33 \%$ (рис. 2). 
Рисунок 1. Бюджет 7РП по приоритетным тематическим направлениям, млрд. евро

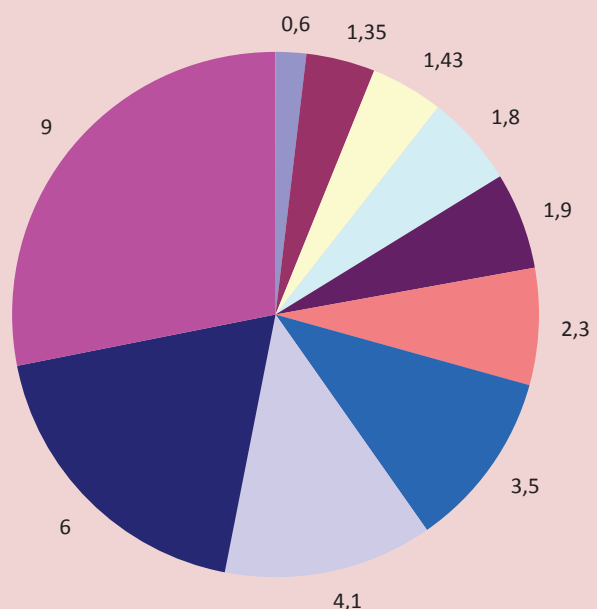

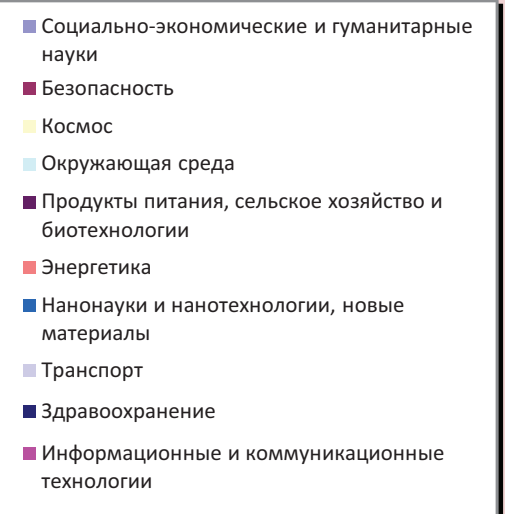

Рисунок 2. Финансирование проектов по направлению «Социально-экономические и гуманитарные науки» 7РП, млн. евро

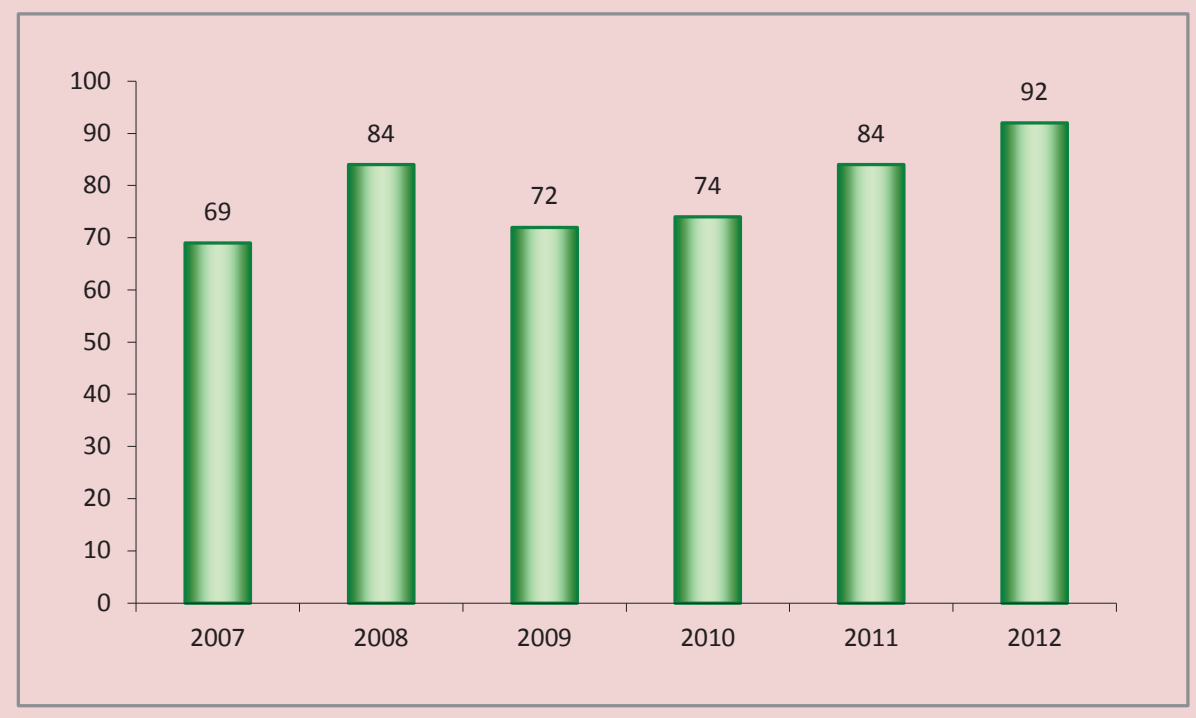

Источник: European Commission. Research \& Innovation. FP7. Statistics [Электронный ресурс]. - Режим доступа: http://ec.europa. eu/research/fp7/index_en.cfm?pg=budget

Тем не менее доля участия российских организаций в проектах по данному направлению 7РП является незначительной. За исследуемый период было поддержано 199 проектов ${ }^{1}$. Российские организации

1 Источник: Sixth FP7 Monitoring Report. Monitoring Report 2011 [Электронный ресурс]. - Режим доступа: http://ec.europa.eu/research/evaluations/index_en.cfm?pg $=\mathrm{fp} 7$-monitoring были представлены только в девяти поддержанных проектах ${ }^{2}$ (информация о них приведена в табл. 3).

2 Источник: Официальный сайт Федерального государственного автономного образовательного учреждения высшего профессионального образования «Национальный исследовательский университет «Высшая школа экономики». Russian Participation in FP7 (December 2012). - Режим доступа: http://www.hse.ru/data/2013/04/02/1294165375/ RU\%20participation\%20FP7.pdf 
Таблица 3. Информация о поддержанных проектах с российским участием по направлению «Социально-экономические и гуманитарные науки» 7РП в 2007-2013 гг.

\begin{tabular}{|c|c|c|c|c|}
\hline $\begin{array}{l}\text { № } \\
\Pi / \Pi\end{array}$ & Тема проекта с российским участием & Российская организация, город & $\begin{array}{l}\text { Бюджет } \\
\text { проекта, } \\
\text { млн. евро }\end{array}$ & $\begin{array}{c}\text { Дата начала } \\
\text { реализации проекта }\end{array}$ \\
\hline 1. & $\begin{array}{l}\text { Транснациональное сотрудничество } \\
\text { национальных контактных центров по } \\
\text { направлению социально-экономиче- } \\
\text { ские и гуманитарные науки. }\end{array}$ & $\begin{array}{l}\text { Федеральное государственное бюджетное } \\
\text { научное учреждение «Научно-исследо- } \\
\text { вательский институт - Республиканский } \\
\text { исследовательский научно-консультаци- } \\
\text { онный центр экспертизы», г. Москва }\end{array}$ & $\begin{array}{l}3,10 \\
2,22 \\
1,20\end{array}$ & $\begin{array}{l}01.02 .2008 \\
01.02 .2011 \\
01.02 .2013\end{array}$ \\
\hline 2. & $\begin{array}{l}\text { Взаимодействие европейских, на- } \\
\text { циональных и региональных особен- } \\
\text { ностей: нации между государствами, } \\
\text { располагающимися вдоль новых вос- } \\
\text { точных границ Европейского союза. }\end{array}$ & $\begin{array}{l}\text { Федеральное государственное бюджетное } \\
\text { образовательное учреждение высшего } \\
\text { профессионального образования «Мо- } \\
\text { сковский государственный университет } \\
\text { им. М.В. Ломоносова», г. Москва }\end{array}$ & 1,73 & 01.04 .2008 \\
\hline 3. & $\begin{array}{l}\text { Развитие наукоёмкого предпринима- } \\
\text { тельства и инноваций в целях роста и } \\
\text { социального благополучия в Европе. }\end{array}$ & $\begin{array}{l}\text { Федеральное государственное образова- } \\
\text { тельное бюджетное учреждение высшего } \\
\text { профрессионального образования «Фи- } \\
\text { нансовый университет при Правительстве } \\
\text { Российской Федерации» (Финансовый } \\
\text { университет), г. Москва }\end{array}$ & 4,28 & 01.01 .2009 \\
\hline 4. & $\begin{array}{l}\text { По направлению к топографии толе- } \\
\text { рантности и равного уважения. Срав- } \\
\text { нительное изучение политик размеще- } \\
\text { ния мест общего пользования в куль- } \\
\text { турно разнородных обществах. }\end{array}$ & $\begin{array}{l}\text { Федеральное государственное авто- } \\
\text { номное образовательное учреждение } \\
\text { высшего профрессионального образова- } \\
\text { ния «Уральский феедеральный универ- } \\
\text { ситет им. первого Президента России } \\
\text { Б.Н. Ельцина», г. Екатеринбург }\end{array}$ & 1,72 & 01.01 .2010 \\
\hline 5. & $\begin{array}{l}\text { Европейские регионы, внешние гра- } \\
\text { ницы ЕС и ближайшие соседи. Анализ } \\
\text { вариантов регионального развития на } \\
\text { основе политик и практик трансгранич- } \\
\text { ного сотрудничества. }\end{array}$ & $\begin{array}{l}\text { Автономная некоммерческая организация } \\
\text { «центр независимых социологических ис- } \\
\text { следований», г. Санкт-Петербург }\end{array}$ & 3,34 & 01.03 .2011 \\
\hline 6. & $\begin{array}{l}\text { Воспоминания, молодёжь, политиче- } \\
\text { ское наследие и гражданская актив- } \\
\text { ность. }\end{array}$ & $\begin{array}{l}\text { Государственное учреждение Ульяновско- } \\
\text { го государственного университета «На- } \\
\text { учно-исследовательский центр «Регион», } \\
\text { г. Ульяновск }\end{array}$ & 9,95 & 01.06 .2011 \\
\hline 7. & $\begin{array}{l}\text { Обмен ресурсами знаний: межрегио- } \\
\text { нальное сплочение областей. }\end{array}$ & $\begin{array}{l}\text { Федеральное государственное автоном- } \\
\text { ное образовательное учреждение выс- } \\
\text { шего профессионального образования } \\
\text { «Национальный исследовательский уни- } \\
\text { верситет «Высшая школа экономики», } \\
\text { г. Москва }\end{array}$ & 3,27 & 01.08 .2011 \\
\hline \multirow[t]{2}{*}{8.} & \multirow[t]{2}{*}{$\begin{array}{l}\text { Вопросы границ, политической обста- } \\
\text { новки, социальной сферы: потенциалы } \\
\text { и проблемы развивающихся концеп- } \\
\text { ций границ в мире после холодной } \\
\text { войны. }\end{array}$} & $\begin{array}{l}\text { Автономная некоммерческая организация } \\
\text { «Центр независимых социологических ис- } \\
\text { следований», г. Санкт-Петербург }\end{array}$ & \multirow{2}{*}{8,99} & \multirow{2}{*}{01.06 .2012} \\
\hline & & $\begin{array}{l}\text { Федеральное государственное бюджетное } \\
\text { учреждение науки «Институт географии } \\
\text { Российской академии наук», г. Москва }\end{array}$ & & \\
\hline 9. & $\begin{array}{l}\text { Социальные инновации: движущая } \\
\text { сила изменений в обществе. }\end{array}$ & $\begin{array}{l}\text { Федеральное государственное бюджетное } \\
\text { учреждение науки «Институт социаль- } \\
\text { но-экономического развития территорий } \\
\text { Российской академии наук», г. Вологда }\end{array}$ & 6,06 & $01.01 .2014^{\star *}$ \\
\hline \multicolumn{5}{|c|}{$\begin{array}{l}\text { * Проект дважды возобновлялся по завершении. Таким образом, было поддержано три проекта по соответствующей теме. } \\
\text { ** На момент подготовки статьи координатором проекта велись переговоры о заключении грантового соглашения. В связи с } \\
\text { этим 01.01.2014 г. представляет собой ориентировочную дату начала реализации проекта. } \\
\text { Источник: Официальный сайт Седьмой рамочной программы ЕС. - Режим доступа: http://cordis.europa.eu/fp7/home_en.html }\end{array}$} \\
\hline
\end{tabular}


Текущий объём финансирования российских организаций по указанному направлению в настоящее время также находится на низком уровне. Общий объём финансирования поддержанных проектов составил 475 млн. евро (199 проектов). За счет участия в девяти поддержанных проектах российские организации получили финансирование в размере 1,31 млн. евро, что составляет только $0,28 \%$ от общего объёма выделенных средств.

В целом за данный период на проекты с российским участием из бюджета 7РП было выделено 73,67 млн. евро, на проекты без российского участия - 401,33 млн. евро.

В целом российские организации имеют незначительный опыт участия в 7РП по социально-гуманитарному направлению (например, в 2010 г. было подано всего лишь семь заявок на участие).

Кроме того, следует отметить, что большинство российских участников конкурсов 7РП - это предприятия, вузы и научноисследовательские организации городов Москвы и Санкт-Петербурга. Активность участия остальных регионов значительно ниже, соответствующим опытом обладают немногие территории.

Что касается Вологодской области, то единственной организацией, подававшей заявки на поддержание научно-исследовательских проектов в рамках 7РП, является Институт социально-экономического развития территорий РАН.

ИСЭРТ РАН рассматривает развитие научных связей с зарубежными коллегами как важнейшее направление деятельности научно-исследовательской организации. Как результат, за последние годы значительно возросло количество мероприятий международного уровня, проводимых Институтом, а также при его участии. В течение 2011-2012 гг. сотрудники отдела инновационной экономики вели актив- ную работу с целью поиска зарубежных партнёров для международных проектов Института, и в начале 2012 г. он впервые принял участие в конкурсах европейских рамочных программ, что является ценным научно-исследовательским опытом.

Работа по подготовке международных проектов весьма трудоёмка в связи с тем, что требует одновременно с выполнением непосредственно научной работы решения ряда дополнительных задач, среди которых:

1. Мониторинг наиболее подходящих для организации возможностей, учёт всех необходимых условий участия, которые, как правило, в полном виде доступны лишь через иностранные ресурсы.

2. Привлечение к участию в проекте опытных учёных для повышения конкурентоспособности работы.

3. Поиск международных партнёров, обладающих необходимой компетенцией (для участия в международном конкурсе зачастую требуется участие более двух стран).

4. Ведение переговоров с партнёрами, деловой переписки на английском языке в ходе подготовки заявки, что, наряду с поиском партнёров, составляет значительную часть всех работ.

В работе над проектами ИСЭРТ РАН значительную помощь оказали международные научно-практические семинары. Результатами переговоров, проведённых в ходе этих семинаров, стали концепции совместных проектов, планы совместных работ.

5. Качественный перевод на английский язык рабочих материалов в течение всей работы над проектом (для обмена информацией с партнёрами) и конечного варианта работы. Вышеперечисленное требует от самих участников хорошего владения английским языком. 
Ключевыми критериями успешной работы по подготовке проектов 7РП стали активное содействие и непрерывная поддержка со стороны руководства Института. Информация о результатах подготовки заявок регулярно заслушивалась на совещаниях; требующие принятия решения вопросы выносились на обсуждение; повышенное внимание участию в 7РП уделялось на заседаниях Учёного совета. Кроме того, данное направление работы было обеспечено молодыми кадрами, которые выполняли большинство соответствующих задач, в частности перевод материалов проектов.

На этой основе в 2012 году расширилось сотрудничество Института по подготовке одной из заявок для 7РП с Центром социальных исследований Технического университета г. Дортмунда (Германия). В сентябре 2012 года в ИСЭРТ РАН состоялся семинар «Проблемы разработки и внедрения социальных инноваций», организованный в рамках визита немецких коллег в Вологду. В ходе семинара обсуждалась разработанная в Центре социальных исследований концепция социальных инноваций. По данному направлению исследований Центр занимает лидирующие позиции в Европе, поскольку он стал одной из первых организаций, уделивших серьёзное внимание изучению вопросов социальных инноваций. По результатам встречи в Вологде между ИСЭРТ РАН и Центром социальных исследований подписан протокол о намерениях, заложивший основу для подготовки нового проекта 7РП.

Итогом работы стало вхождение Института в международный консорциум, подготовка и подача на участие в конкурсе программы «Социально-экономические и гуманитарные науки» 7РП совместной заявки - «Социальные инновации: фактор изменений в обществе». Центр социальных исследований выступил в роли координатора консорциума.
В июне 2013 года службы Европейской комиссии сообщили консорциуму о том, что заявка получила 14 из 15 баллов по результатам экспертизы, и о намерении Европейской комиссии поддержать проект и начать переговоры о заключении грантового соглашения. В настоящее время координатором ведутся соответствующие переговоры, включающие, в частности, подготовку необходимых документов, соглашений и их согласование с партнёрами по проекту.

Таким образом, научно-исследовательские работы ИСЭРТ РАН получили положительную оценку коллег из Европы, Америки, других частей света, что позволило принять участие в Седьмой рамочной программе ЕС, являющейся действенным инструментом интеграции в Европейское научно-исследовательское пространство.

В проекте принимают участие пятнадцать партнёров из двенадцати государствчленов ЕС и одиннадцать партнёров из других регионов мира. В список стран, представляемых участниками, входят: Австралия, Австрия, Бельгия, Болгария, Великобритания, Германия, Египет, Индия, Испания, Италия, Канада, Китай, Колумбия, Литва, Нидерланды, Российская Федерация, Румыния, Турция, Хорватия, Чили, Швеция, Южная Африка (табл. 4).

Проект предназначен для расширения научных знаний о социальных инновациях по трём основным направлениям:

- интеграция теорий и научно-исследовательских методологий в целях лучшего понимания сущности социальных инноваций, что позволит внести вклад в построение «полной», всесторонней парадигмы инноваций;

- выявление и анализ социальных инноваций, реализованных и осваиваемых на европейском уровне и в мировом масштабе, и посредством этого изучение 
Таблица 4. Участники проекта «Социальные инновации: фрактор изменений в обществе»

\begin{tabular}{|c|c|c|}
\hline $\begin{array}{l}\text { № } \\
\Pi / \Pi\end{array}$ & Участник & Страна \\
\hline 1. & $\begin{array}{l}\text { Координатор проекта } \\
\text { Технический университет Дортмунда/Центр социальных исследований }\end{array}$ & Германия \\
\hline 2. & Институт труда и технологий (Вестфальский специализированный вуз Гельзенкирхена) & Германия \\
\hline 3. & Нидерландская организация прикладных научных исследований & Нидерланды \\
\hline 4. & Британский фонд имени Янга & Великобритания \\
\hline 5. & Университет имени Брюнеля & Великобритания \\
\hline 6. & Центр социальных инноваций в городе Вене & Австрия \\
\hline 7. & Австрийский институт технологий в городе Вене & Австрия \\
\hline 8. & Университет Деусто & Испания \\
\hline 9. & Лаборатория социальных инноваций & Хорватия \\
\hline 10. & Фонд прикладных исследований и сообщений & Болгария \\
\hline 11. & Международная организация экономики знаний и развития предприятий & Швеция \\
\hline 12. & Университет имени Казимераса Симонавичуса & Литва \\
\hline 13. & Университет «Данубиус» в городе Галаце & Румыния \\
\hline 14. & Агентство развития и сотрудничества «ЛАМА» в городе Флоренции & Италия \\
\hline 15. & Стамбульский технический университет & Турция \\
\hline 16. & Гелиопольский университет в городе Каире & Египет \\
\hline 17. & $\begin{array}{l}\text { Институт социально-экономического развития территорий Российской академии наук в } \\
\text { городе Вологде }\end{array}$ & Российская Федерация \\
\hline 18. & Чжэцзянский университет в городе Ханчжоу & Китай \\
\hline 19. & $\begin{array}{l}\text { Университет Кейптауна - Центр социальных инноваций и предпринимательства «Берта» } \\
\text { в городе Кейптауне }\end{array}$ & Южная Африка \\
\hline 20. & $\begin{array}{l}\text { Экономическая комиссия Организации Объединённых Наций по вопросам стран Латин- } \\
\text { ской Америки и Карибского региона }\end{array}$ & Чили \\
\hline 21. & $\begin{array}{l}\text { Центр социальных инноваций, Национальное агентство по борьбе с крайней нищетой в } \\
\text { городе Боготе }\end{array}$ & Колумбия \\
\hline 22. & Университет Сиднея, Австралийский центр инноваций в городе Сиднее & Австралия \\
\hline 23. & Институт социальных наук имени Таты в городе Мумбаи & Индия \\
\hline 24. & $\begin{array}{l}\text { Университет имени Саймона Фрейзера в городе Ванкувере, Центр политических иссле- } \\
\text { дований в области науки и технологий }\end{array}$ & Канада \\
\hline 25. & Центр изучения социальных инноваций Университета Квебека & Канада \\
\hline 26. & Европейская федерация национальных организаций по работе с бездомными & Бельгия \\
\hline
\end{tabular}

социальных, экономических, культурных, исторических и других аспектов данных процессов в восьми главных регионах мира; - обеспечение органов власти и управления, а также лиц, к деятельности которых непосредственно относятся изучаемые вопросы, релевантными данными, полученными на основе всестороннего анализа и проведения ситуационных исследований в рамках семи областей политики (включая проведение европейских и мировых сравнений, разработку прогнозов и организацию конференций/семинаров по вопросам политики в области социальных инноваций).
$* * *$

В начале статьи подчеркнута важность проблемы разработки и внедрения социальных инноваций. Поскольку в ИСЭРТ РАН ведётся научно-исследовательская работа в данной области, считаем необходимым раскрыть содержание и особенности понятия «социальные инновации». Более подробного освещения требует также ряд аспектов, обусловливающих специфику изучения вопросов возникновения и развития социальных инноваций. Наша статья написана с использованием материалов, подготовленных при выполнении работы по гранту РФФИ. 
Таблица 5. Трактовки понятия «социальные инновации»

\begin{tabular}{|c|c|c|}
\hline $\begin{array}{l}\text { № } \\
\text { ח/П }\end{array}$ & Автор & Трактовка \\
\hline 1. & $\begin{array}{l}\text { Копотева И.В., } \\
\text { Никула Й. }\end{array}$ & $\begin{array}{l}\text { Социальные инновации - это производство и интеграция новых знаний в форме про- } \\
\text { грамм, организационных моделей или определённого набора принципов и других } \\
\text { средств, используемых на местном уровне для реагирования на положительные и отри- } \\
\text { цательные результаты реструктуризации*. }\end{array}$ \\
\hline 2. & Малгэн Д. & $\begin{array}{l}\text { Социальные инновации - новые идеи, работающие в форме воспроизводимых программ } \\
\text { или организаций для удовлетворения неотложных неудовлетворённых потребностей и } \\
\text { улучшения жизни людей }{ }^{* *} \text {. }\end{array}$ \\
\hline 3. & Мамсрорд М. & $\begin{array}{l}\text { Социальная инновация - генерирование и реализация новых идей о людях и их взаимо- } \\
\text { действии внутри социальной системы***. }\end{array}$ \\
\hline 4. & Ховальдт Ю., Шварц М. & $\begin{array}{l}\text { Социальные инновации представляют собой новое сочетание или новую форму соци- } \\
\text { альной деятельности в конкретных областях или социальном контексте, осуществляе- } \\
\text { мые конкретными лицами или группой лиц продуманными способами с целью лучшего } \\
\text { удовлетворения или соответствия потребностям и проблемам, нежели это возможно на } \\
\text { основе существующей практики }{ }^{* \star \star \star . ~}\end{array}$ \\
\hline \multicolumn{3}{|c|}{$\begin{array}{l}\text { * Копотева И.В., Никула Й. Социальные инновации в изменяющейся сельской среде России // Экономические и социальные пере- } \\
\text { мены: факты, тенденции, прогноз. - Вологда, 2008. - №2. - С. } 76 . \\
\text { ** Social Innovation: what is it, why it matters, how it can be accelerated / G. Mulgan et al. - London: Young Foundation, } 2006 . \\
\text { *** Mumford M.D. Social Innovation: Ten Cases from Benjamin Franklin // Creativity Research Journal. - 2002. - №14(2). - P. } 253 \text { - } 266 . \\
\text { **** Howaldt J., Schwarz M. Social Innovation: Concepts, Research Fields and International Trends - IMA/ZLW \& IfU - RWTH. - Aachen } \\
\text { Aachen University, 2010. }\end{array}$} \\
\hline
\end{tabular}

В настоящее время учёные предлагают множество различных трактовок понятия «социальные инновации», зачастую имеющих немаловажные отличия (табл. 5). На основе изучения взглядов ряда европейских исследователей отметим, что, по нашему мнению, трактовка, предложенная учёными из Германии Ю. Ховальдтом и М. Шварцем, отражает главные аспекты изучаемого понятия и может стать ориентиром дальнейших исследований в данной области ${ }^{3}$.

На основе сопоставления социальных инноваций с материально-техническими можно выделить ряд особенностей первых:

1. Источником возникновения социальных инноваций в большинстве случаев является коллективное творчество; вероятность возникновения на основе индивидуального труда выше в случае материальнотехнических инноваций.

\footnotetext{
3 Кузьмин И.В. Социальные инновации: сущность и влияние на экономическое развитие // Материалы Межрегиональной научно-практической конференции «Социальный капитал как ресурс модернизации в регионе: проблемы формирования и измерения», г. Череповец, 16-17 октября 2012 г.: в 2-х т. - Череповец: ЧГУ, 2012. T. 2. - C. 14-19.
}

\section{2. Результат внедрения социальных} инноваций не проявляется настолько быстро, не носит такого конкретного характера, каким чаще всего обладают материально-технические инновации.

3. Специфика социальных инноваций, кроме того, заключается в их более чёткой обусловленности внешней средой. Здесь можно провести аналогию с существующим в общей теории инноваций подходом, носящим условное название «давление спроса», в соответствии с которым разработку нововведений, распространение инноваций обеспечивает рост спроса. В качестве «спроса» в данном случае выступают возникающие социальные проблемы, которые невозможно решить с помощью традиционных методов.

4. Более широкая потенциальная сфера реализации. В частности, область использования социальной инновации в зависимости от групповых и личностных качеств субъектов, а также целевой аудитории, задействованных в освоении данной инновации, может быть изменена. 
Отсюда следует, что внедрение социальных инноваций можно разделить на «точечное», предполагающее их освоение на определённом объекте (здесь возможно как разовое внедрение, так и регулярное, в зависимости от целей конкретной инновации), и «пространственное», предполагающее дальнейшее распространение инноваций на многие объекты. Говоря о масштабе социальных инноваций, необходимо также отметить их разный характер: инновации, имеющие значение для решения общечеловеческих проблем; инновации, внедрение которых особенно актуально для отдельных регионов; инновации местного значения. При рассмотрении социальных инноваций с точки зрения общественной жизни возможно выделить инновации, направленные на развитие социальных институтов, политической, экономической, культурнодуховной сфер.

При разработке социальных инновационных проектов лицам, принимающим решения, необходимо определять их специфические особенности, обусловливаемые адресностью сферы реализации, что обеспечивает достижение лучших конечных результатов.
По нашему мнению, социальные инновации классифицируются по ряду признаков (табл. 6).

Помимо предложенной группировки социальных инноваций их возможно систематизировать в соответствии с той более конкретной сферой деятельности, в которой осваивается социальная инновация. В проекте 7РП «Социальные инновации: фактор изменений в обществе» (далее - Проект) предусмотрено проведение в разных странах и группах стран исследований социальных инноваций в нескольких сферах, в частности науке, образовании и обучении на протяжении всей жизни; занятости (в т. ч. в малом и среднем бизнесе); медицинской и социальной помощи.

Необходимо также отметить, что, несмотря на постепенно возрастающий в настоящее время интерес научных кругов, органов власти и управления, общественности к теме социальных инноваций, безоговорочное лидерство по уровню и глубине исследований принадлежит таким видам инноваций, как технические (создание новых продуктов, технологий, оборудования, материалов), организационные (совершенствование организационной структуры

Таблица 6. Разработанная классификация социальных инноваций

\begin{tabular}{|c|c|}
\hline Классификационный признак & Виды социальных инноваций \\
\hline По способу разработки & $\begin{array}{l}\text { Индивидуальные } \\
\text { Коллективные }\end{array}$ \\
\hline По уровню социальных нововведений & $\begin{array}{l}\text { Глобального характера, направленные на решение общечеловеческих проблем } \\
\text { Региональные } \\
\text { Локальные, представляющие более узкие интересы регионального и местного } \\
\text { значения }\end{array}$ \\
\hline По виду эфффекта & $\begin{array}{l}\text { Целевые } \\
\text { Косвенного воздействия }\end{array}$ \\
\hline По способу реализации & $\begin{array}{l}\text { Инициируемые органами власти } \\
\text { Инициируемые предприятиями } \\
\text { На основе государственно-частного партнёрства }\end{array}$ \\
\hline По сфрерам общественной жизни & $\begin{array}{l}\text { В социальных структурах и институтах } \\
\text { Политические } \\
\text { Экономические } \\
\text { Инновации в культурно-духовной сфрере }\end{array}$ \\
\hline По масштабу использования & $\begin{array}{l}\text { Единичные социальные инновации, осуществляемые на одном объекте } \\
\text { Дифффузные, распространяемые на многие объекты }\end{array}$ \\
\hline
\end{tabular}


управления предприятиями), экономические (использование не применявшихся ранее систем и форм оплаты труда, методов управления издержками производства), маркетинговые (освоение новых рынков сбыта и способов продвижения продукции), экологические (реализация новых технологий в области охраны окружающей среды) и другие инновации. В гораздо меньшей степени исследуются социальные инновации, хотя они являются немаловажным условием активизации вышеперечисленных процессов (например, не отражается в официальных статистических сборниках внедрение и разработка социальных инноваций; неразработанными остаются проблемы их измерения).

Приоритетное значение для оценки, измерения социальных инноваций в регионах имеет мониторинг деятельности по их внедрению. Изучение информации о существующих научных подходах, об опыте разработки концепций, методов измерения и проведения мониторинга социальных инноваций позволяет сделать вывод, что методики оценки социальных инноваций как таковые не разработаны либо не завершены. Количественное и числовое измерение результатов внедрения социальных инноваций весьма затруднено, что делает их учёт и анализ труднодоступными.

Применяемые для анализа данные, с помощью которых можно попытаться описать ситуацию в области освоения социальных инноваций, делятся на две группы в зависимости от источника данных: показатели, рассчитываемые на основе объективной статистики; показатели, рассчитываемые на основе субъективной статистики. Однако, как было отмечено выше, статистические сведения об инновационной деятельности российских предприятий не содержат какой-либо информации о социальных инновациях. На сегодняшний день для проведения оценки реализуемых социальных инноваций и мониторинга последних наиболее подходящим является метод, основанный на расчёте показателей, выводимых из данных субъективной статистики, в частности опросов, интервью экспертов и т. д. Участие в Проекте позволит научным коллективам, занимающимся исследованиями социальных инноваций, рассмотреть способы решения данной проблемы на местном, национальном и наднациональном уровнях, что, в свою очередь, должно привести к формированию более проработанного подхода к анализу социальных инноваций.

Проект позволит участникам осуществлять обмен релевантной научно-исследовательской информацией, теоретическими разработками, методами исследований; подготовить совместное видение теоретической концепции социальных инноваций. В рамках изучения теоретико-методологических аспектов социальных инноваций будет расширено понимание их сушности и особенностей. Кроме того, будут проведены всесторонние ситуационные исследования отечественных и зарубежных практик разработки и внедрения социальных инноваций. Зарубежный опыт последних, как следует из выводов, полученных ИСЭРТ РАН в ходе научно-исследовательской работы по проекту Российского фонда фундаментальных исследований «Повышение консолидации населения на основе социальных инноваций» (грант РФФИ №12-06-00379-а), подтверждает позитивное влияние разработки и внедрения социальных инноваций на качество жизни населения.

В связи с этим проект «Социальные инновации: фактор изменений в обществе» имеет высокую социально-экономическую значимость; его результаты в особенности важны для решения вопросов, касающихся перемен в обществе и повышения качества жизни населения. 
С научной точки зрения участие научноисследовательских организаций в рамочных программах ЕС и аналогичных инициативах способствует развитию фундаментальных и прикладных направлений социально-экономических и междисциплинарных исследований в целом. Благодаря работе в международном научноисследовательском коллективе создаются возможности для апробации методологических подходов в условиях разных стран, для всестороннего анализа результатов научных работ, разработки и реализации практических рекомендаций.
Кроме того, совместные проекты позволяют сформировать более объективное представление о научно-исследовательской работе и социально-экономической ситуации в странах-участницах (в частности, информировать зарубежных коллег о развивающихся в России научных исследованиях).

Таким образом, расширение сотрудничества с зарубежными партнёрами является важнейшим направлением деятельности по интеграции российской науки в глобальные процессы научно-технологического развития.

\section{Литература}

1. Копотева, И.В. Социальные инновации в изменяющейся сельской среде России / И.В. Копотева, Й. Никула // Экономические и социальные перемены: факты, тенденции, прогноз. - 2008. - №2. - С. 76.

2. Кузьмин, И.В. Кратко о Седьмой рамочной программе Европейского союза / И.В. Кузьмин // Инновационная деятельность: проблемы, практика коммерциализации [Текст]: сборник материалов VI научно-практического семинара «Инновационная деятельность: вопросы коммерциализации технологий». - Вологда: Институт социально-экономического развития территорий РАН, 2012. - С. 41-44.

3. Кузьмин, И.В. Социальные инновации: сущность и влияние на экономическое развитие / И.В. Кузьмин // Материалы Межрегиональной научно-практической конференции «Социальный капитал как ресурс модернизации в регионе: проблемы формирования и измерения», г. Череповец, 16-17 октября 2012 г.: в 2-х т. - Череповец: ЧГУ, 2012. - Т. 2. - С. 14-19.

4. Маковеев, В.Н. Отечественный опыт государственного регулирования инновационных процессов в промышленности / В.Н. Маковеев // Молодой учёный. - 2013. - №4. - С. 262-265.

5. Официальный сайт Седьмой рамочной программы ЕС. - Режим доступа: http://cordis.europa.eu/fp7/ home_en.html

6. Официальный сайт Федерального государственного автономного образовательного учреждения высшего профессионального образования «Национальный исследовательский университет «Высшая школа экономики». Russian Participation in FP7 (December 2012). - Режим доступа: http://www.hse.ru/ data/2013/04/02/1294165375/RU\%20participation\%20FP7.pdf

7. Теребова, С.В. Развитие международного сотрудничества в научно-исследовательской сфере / С.В. Теребова // Проблемы развития территории. - 2012. - №5. - С. 7-10.

8. Теребова, С.В. Трансфер технологий как элемент инновационного развития экономики / С.В. Теребова // Проблемы развития территории. - 2010. - №4. - С. 31-36.

9. Artis, M.J. The Economics of the European Union: Policy and Analysis / M.J. Artis, F. Nixson. - 4th ed. Oxford University Press, 2007.

10. European Commission. Research \& Innovation. FP7. Statistics [Electronic resource]. - Режим доступа: httр:// ec.europa.eu/research/fp7/index_en.cfm?pg=budget

11. Fifth FP7 Monitoring Report. Monitoring Report 2011 [Electronic resource]. - Режим доступа: httр:// ec.europa.eu/research/evaluations/index_en.cfm?pg=fp7-monitoring

12. Howaldt, J. Social Innovation: Concepts, Research Fields and International Trends / J. Howaldt, M. Schwarz. IMA/ZLW \& IfU - RWTH. - Aachen: Aachen University, 2010.

13. Mulgan, G. Social Innovation: what is it, why it matters, how it can be accelerated / G. Mulgan et al. - London: Young Foundation, 2006. 
14. Mumford, M.D. Social Innovation: Ten Cases from Benjamin Franklin / M.D. Mumford // Creativity Research Journal. - 2002. - №14(2). - P. 253-266.

15. Sixth FP7 Monitoring Report. Monitoring Report 2011 [Electronic resource]. - Режим доступа: http:// ec.europa.eu/research/evaluations/index_en.cfm?pg=fp7-monitoring

\section{References}

1. Kopoteva I.V., Nikula Y. Sotsial'nye innovatsii v izmenyayushcheysya sel'skoy srede Rossii [Social Innovation in a Changing Rural Environment of Russia]. Ekonomicheskie i sotsial'nye peremeny: fakty, tendentsii, prognoz [Economic and Social Changes: Facts, Trends, Forecast], 2008, no.2, p. 76.

2. Kuzmin I.V. Kratko o Sed'moy ramochnoy programme Evropeyskogo soyuza [Briefly about the Seventh Framework Programme of the European Union]. Innovatsionnaya deyatel'nost': problemy, praktika kommertsializatsii: sbornik materialov VInauchno-prakticheskogo seminara “Innovatsionnaya deya-tel'nost': voprosy kommertsializatsii tekhnologiy" [Innovation Activity: Problems, Commercialization Practice: Proceedings of the 6th Research-to-Practice Seminar "Innovation Activity: Commercialization of Technologies]. Vologda: Institut sotsial'no-ekonomicheskogo razvitiya territoriy RAN, 2012. Pp. 41-44.

3. Kuzmin I.V. Sotsial'nye innovatsii: sushchnost' i vliyanie na ekonomicheskoe razvitie [Social Innovation: the Nature and Impact on Economic Development]. Materialy Mezhregional'noy nauchno-prakticheskoy konferentsii "Sotsial'nyy kapital kak resurs modernizatsii v regione: problemy formirovaniya i izmereniya”, g. Cherepovets, 16-17 oktyabrya 2012 g.: v 2-kh $t$. [Proceedings of the Interregional Research-to-Practice Conference "Social Capital as a Resource for Modernization in the Region: Problems of Formation and Measurement", Cherepovets, October 16-17, 2012: in 2 vols]. Cherepovets: ChGU, 2012. Vol. 2. Pp. 14-19.

4. Makoveev V.N. Otechestvennyy opyt gosudarstvennogo regulirovaniya innovatsionnykh protsessov v promyshlennosti [Domestic Experience of State Regulation of Innovation Processes in Industry]. Molodoy uchenyy [Young Scientist], 2013, no.4, pp. 262-265.

5. Ofitsial'nyy sayt Sed'moy ramochnoy programmy ES [Official Website of the Seventh Framework Programme of the EU]. Available at: http://cordis.europa.eu/fp7/home_en.html

6. Ofitsial'nyy sayt Federal'nogo gosudarstvennogo avtonomnogo obrazovatel'nogo uchrezhdeniya vysshego professional'nogo obrazovaniya "Natsional'nyy issledovatel'skiy universitet "Vysshaya shkola ekonomiki” [Official Website of the Federal State Autonomous Educational Institution of Higher Professional Education "National Research University "Higher School of Economics"]. Russian Participation in FP7 (December 2012). Available at: http://www.hse.ru/data/2013/04/02/1294165375/RU\%20participation\%20FP7.pdf

7. Terebova S.V. Razvitie mezhdunarodnogo sotrudnichestva v nauchno-issledovatel'skoy sfere [Development of International Cooperation in the Sphere of Science and Research]. Problemy razvitiya territorii [Problems of Development of Territories], 2012, no.5, pp. 7-10.

8. Terebova S.V. Transfer tekhnologiy kak element innovatsionnogo razvitiya eko-nomiki [Technology Transfer as an Element of Innovation Economy Development]. Problemy razvitiya territorii [Problems of Development of Territories], 2010, no.4, pp. 31-36.

9. Artis M.J., Nixson F. The Economics of the European Union: Policy and Analysis. 4th edition. Oxford University Press, 2007.

10. European Commission. Research \& Innovation. FP7. Statistics. Available at: http://ec.europa.eu/research/fp7/ index_en.cfm?pg=budget

11. Fifth FP7 Monitoring Report. Monitoring Report 2011. Available at: http://ec.europa.eu/research/evaluations/ index_en.cfm?pg=fp7-monitoring

12. Howaldt J., Schwarz M. Social Innovation: Concepts, Research Fields and International Trends. IMA/ZLW \& IfU. RWTH. Aachen: Aachen University, 2010.

13. Mulgan G. et al. Social Innovation: What Is It, Why It Matters, How It Can Be Accelerated. London: Young Foundation, 2006.

14. Mumford M.D. Social Innovation: Ten Cases from Benjamin Franklin. Creativity Research Journal, 2002, no.14(2), pp. 253-266.

15. Sixth FP7 Monitoring Report. Monitoring Report 2011. Available at: http://ec.europa.eu/research/evaluations/ index_en.cfm?pg=fp7-monitoring 


\section{Оценка формирования региональной инновационной системы провинции Цзянси}

\section{Ма ЧЖИХОЙ}

научный сотрудник, директор, Институт экономики, Академия общественных наук провиции Цзянси, Китай

Ma Zhihui

\section{Assessment of Jiangxi Regional Innovation System Construction}

Ma Zhihui - Research Associate, Director of Institute of Economics of Jiangxi Academy of Social Sciences

Цзянси, будучи менее развитой провинцией Центрального Китая, испытывает недостаток высококвалифицированных кадров, серьёзный недостаток инвестиций в науку; провинция является относительно уязвимой в плане научного инновационного потенциала, имеет неэффективно функционирующий и несовершенный механизм создания и внедрения инноваций на предприятиях. Механизм интеграции и инновационная среда инновационной системы также нуждаются в совершенствовании. Следовательно, построение региональной инновационной системы провинции Цзянси - это стратегическая задача, необходимая для ускорения эко- номического и социального развития, стимулирования процесса индустриализации, содействия оптимизации и обновлению структуры промышленности, а также повышения конкурентоспособности региона.

1. Формирование региональной инновационной системы провинции Цзянси: обзор современной ситуации.

1.1. Формирование образовательной и научно-инновационной системы.

1.1.1. Университеты и научно-исследовательские организации становятся ведущей силой в научных инновациях. К концу 2011 года было основано 86 колледжей, 58 научно-исследовательских учреждений, построенных высшими учебными 
заведениями, с числом научных сотрудников 13326 чел.; 12 центров подготовки докторантов, 43 последокторских научноисследовательских центра. В целом в провинции имеется 113 независимых исследовательских институтов надуездного уровня со штатом 5256 научных сотрудников, 31 независимый исследовательский институт провинциального уровня с числом научных сотрудников и обслуживающего персонала 4501.

1.1.2. Строительство и развитие научнотехнической базы. В настоящее время общее число ключевых лабораторий различных типов (включая лаборатории национального уровня) достигло 67; кроме того, было основано 102 инженерно-технических научно-исследовательских центра (в том числе 5 центров национального уровня). Сферы научно-исследовательской деятельности данных организаций следующие: сельское хозяйство, производство продовольствия, кормов для животных, легкая промышленность, медицина, техника и технологии, гуманитарные и общественные науки и др.

1.1.3. Значительно выросло количество высококвалифицированных специалистов - к концу 2011 года оно достигло по всей провинции 1,7 млн. человек. Среди них 708 тыс. специалистов и технического персонала в различных областях, 112200 занятых в науке и технике, в том числе 52 тыс. ученых и инженеров, а также 4 академика.

1.1.4. Устойчивый рост наблюдается в количестве патентных заявок, выданных патентов и в количестве научно-технических достижений. В 2011 году было подано 9674 патентные заявки, выдано 5500 патентов, зарегистрировано 708 научно-технических достижений по всей провинции, что выше на 53,4, 27,6 и 20,41\% соответственно, чем в предыдущем году, и является рекордным показателем.
1.2. Создается система технологических инноваций для их внедрения на предприятиях.

В конце 2011 года основаны крупные промышленные предприятия, составившие 6481 ед., с персоналом численностью около 240 тыс. человек; 325 научно-исследовательских институтов и 120 технологических центров при предприятиях, в том числе 6 центров национального уровня; на данных предприятиях работают 27500 исследователей, что составляет $66 \%$ их общего количества по провинции. Это свидетельствует о постепенном становлении предприятий как ключевых центров внедрения инноваций.

1.3. Формирование системы посредничества и поддержки науки и технологии.

К концу 2011 года в провинции Цзянси было 7 бизнес-инкубаторов высоких технологий, в том числе 4 - национального уровня; 124 центра наращивания производительности, в том числе 6 - национального уровня. Рынок технологий стал связующим звеном между технологией и экономикой. Была сформирована система рынков 4 уровней: провинции, города, уезда и волости. В целом по провинции было заключено 2262 контракта на общую сумму 3,239 млрд. юаней.

1.4. Формирование системы диверсифицированного финансирования науки.

Финансирование НИОКР производится из нескольких источников: государственные ассигнования, инвестиции предприятий (составляют наибольшую часть), первоначальное привлечение средств финансовых учреждений и иностранного капитала. В 2011 г. общий объем финансирования НИОКР в социальной сфере составил 9,675 млрд. юаней, в том числе 7,835 млрд. юаней инвестиций предприятий на исследовательские цели, 825 млн. юаней из технологических и исследовательских институтов и 799 млн. юаней из высших учебных заведений. В провинции Цзянси есть также 5 учреждений венчурного капитала. 


\section{5. Постоянное совершенствование} системы защиты науки и технологии.

В провинции Цзянси был принят ряд политических мер и нормативных документов, направленных на стимулирование технологических инноваций, ускорение коммерциализации и внедрения достижений НИОКР, например: комитет КПК провинции Цзянси, Народное правительство провинции Цзянси исполняют Рекомендации по укреплению технологических инноваций; меры по развитию высоких технологий и проведению индустриализации; а также предложения Народного правительства провиниии Цзянси по активной реализации стратегии развития Цзянси через образование и науку и укрепление провинции путем развития талантов; Постановление об управлении рынком технологий Цзянси; Постановление о содействии коммерииализации результатов научных исследований; Решение Народного правительства провинции Цзянси активно развивать частные научно-технические предприятия, систему поощрения науки и техники в провинции Цзянси; Решение Народного правительства провинции Цзянси о реформе системы управления независимыми НИИ провинции; некоторые политические меры по содействию развитию высокотех- нологичных отраслей провинции Цзянси, внедрению пробных мер по управлению негосударственными технопарками; пробные меры по управлению субсидиями на научнотехнические проекты Агентства по науке и технологии провинции Цзянси. Данные политические меры и нормативные документы будут способствовать непрерывному улучшению инновационной научно-технической среды.

2. Оценка региональной инновационной системы провинции Цзянси.

Согласно информации Национального министерства по науке и технологии, индексу инновационного потенциала регионов Китая и позиции Цзянси в 2011 году по данному показателю, а также согласно индексу статистического наблюдения и позиции Цзянси в национальном рейтинге научно-технического прогресса, можно сделать вывод о том, что региональная инновационная система провинции Цзянси находится на уровне ниже среднего по стране (табл. 1).

Потенциал инновации знаний включает 3 показателя: финансирование НИОКР, патенты и научно-исследовательские публикации; потенциал приобретения знаний включает 3 показателя: научное

Таблица 1. Место провинции Цзянси в рейтинге инновационного потенциала регионов Китая (2011 г.)

\begin{tabular}{|c|c|c|c|c|c|}
\hline Показатель & $\begin{array}{c}\text { Общие } \\
\text { показатели }\end{array}$ & $\begin{array}{c}\text { Устойчивость } \\
\text { (подпункт) }\end{array}$ & $\begin{array}{l}\text { Эфрфективность } \\
\text { (подпункт) }\end{array}$ & $\begin{array}{l}\text { Потенциал } \\
\text { (подпункт) }\end{array}$ & $\begin{array}{l}\text { Позиция } \\
\text { в рейтинге }\end{array}$ \\
\hline Общее значение & 22 & 20 & 24 & 6 & 18 \\
\hline Генерация знаний & 26 & 21 & 27 & 4 & 22 \\
\hline Приобретение знаний & 25 & 24 & 18 & 16 & 21 \\
\hline $\begin{array}{l}\text { Технологический инновационный } \\
\text { потенциал предприятия }\end{array}$ & 27 & 22 & 26 & 25 & 25 \\
\hline $\begin{array}{l}\text { Технологическая инновационная } \\
\text { среда и управление технологиче- } \\
\text { скими инновациями }\end{array}$ & 16 & 22 & 26 & 29 & 27 \\
\hline $\begin{array}{l}\text { Экономическая выгода от пред- } \\
\text { принимательства }\end{array}$ & 14 & 15 & 10 & 18 & 14 \\
\hline
\end{tabular}


сотрудничество, трансформация технологий и прямые зарубежные инвестиции; технологический инновационный потенциал предприятия состоит из 4 показателей: инвестиции в НИОКР предприятия, проектный потенциал, потенциал обработки и производства, доход от продаж новой продукции; технологическая инновационная среда состоит из 5 показателей: инновационная инфраструктура, уровень рыночного спроса, качество рабочей силы, финансовая среда и уровень предпринимательства; экономическая выгода от предпринимательства состоит из 5 показателей: макроэкономика, структура промышленности, конкурентоспособность продукции на международном рынке, уровень занятости, устойчивое развитие и защита окружающей среды (табл. 2).

3. Проблемы региональной инновационной системы провинции Цзянси.

Недостаточное совокупное финансирование научно-технической сферы.

За последние годы, несмотря на увеличение финансирования научно-технической сферы со стороны правительства на всех уровнях, по-прежнему актуальной остается проблема недостаточного совокупного финансирования. Доля средств, выделяемых на научно-техническую сферу из бюджета провинции, не увеличивается, и ее уровень ниже, чем в других регионах страны. Доля средств на НИОКР относительно ВВП намного меньше, чем в целом по стране. Развитие системы финансирования науки и техники в провинции Цзянси сравнительно отстает. Венчурный капитал науки и техники, банковские кредиты, общественные финансы и другие многоканальные системы финансирования науки и техники являются несовершенными. Вследствие длительной нехватки инвестиций в научно-техническую сферу, устаревшего оборудования, неэффективных мер, результаты неудовлетворительные и уровень низкий, что не отвечает требованиям экономического и социального развития в научно-технической сфере.

Менее независимые права на объекты интеллектуальной собственности и технические достижения.

С точки зрения технологий провинция является относительно слабой, особенно в сфере передовых технологий, для которых характерны высокая сложность и взаимосвязь с множеством отраслей. В свете национального статистического мониторинга за 2012 год, 5 основных показателей провинции Цзянси, включая показатель условий для научно-технического прогресса, показатель затрат на науку и технику, показатель выхода продукции научно-технической сферы, показатель высокотехнологичной промышленности, науки и технологии, направленных на поддержку экономического и социального развития, не только ниже, чем в среднем по стране, но и среди 6 центральных провинций Китая.

Таблица 2. Рейтинг провинции Цзянси в статистическом мониторинге национального научно-технического прогресса (2011 г.)

\begin{tabular}{|l|c|c|}
\hline \multicolumn{1}{|c|}{ Показатель } & Значение & Позиция \\
\hline Условия для научно-технического прогресса & 41,99 & 24 \\
\hline Инвестиции в научно-технические разработки & 37,09 & 23 \\
\hline Выход научно-технической продукции & 21,84 & 27 \\
\hline Высокотехнологичная индустриализация & 49,15 & 12 \\
\hline Наука и технологии, ускоряющие социально-экономическое развитие & 57,99 & 28 \\
\hline Источник: статистические данные по науке и технике провинции Цзянси, 2012. \\
\hline
\end{tabular}


Нехватка высококвалифицированных кадров в научно-технической инновационной coepe.

В частности, наблюдается существенный недостаток руководителей в научной, инженерной сфере и в сфере высоких технологий, нехватка руководителей в наукоемких отраслях и высококвалифицированных специалистов в сфере технологических инноваций. Количество центров подготовки докторантов и количество рабочих мест для последокторских научных исследований на предприятиях ограничивается одним ключевым университетом или городом в развитой провинции.

Не закончено формирование системы технологических инноваций, сосредоточенной вокруг предприятий.

Вследствие неэффективной реформы собственности, предприятия утратили инициативный стимул; меньший объем финансирования и несовершенный организационный механизм технологических инноваций замедляют технологическое развитие предприятий. В 2011 году 34,28\% потенциала технологического развития было отделено от предприятий, и только половина крупных и средних предприятий имеет организованное технологическое развитие, однако эти предприятия являются слабыми в плане инноваций.

Отставание в области реформирования и инноваций в научно-технической сфере $и$ механизме управления.

Большинство научно-исследовательских институтов провинции до сих пор функционируют в традиционном режиме, для которого характерно следующее: слабая экономическая основа, недостаток кадрового резерва, узкая специализация, что затрудняет реализацию проектов с необходимостью высокой технологической интеграции. Исследовательские институты могут иметь дело с отдельными технологиями, однако они по-прежнему беспомощны, когда речь идет о сложных технологиях, которые требуются на предприятиях. Развитие различных научнотехнических посредников отстает, и они не играют эффективной роли в совокупном эффекте и обслуживающей функции научно-технических достижений.

4. Политика и меры, направленные на формирование региональной инновационной системы провинции Цзянси.

4.1. Активная реализация программы «1368» для создания региональной инновационной системы провинции Цзянси.

А. Главная программа: укрепление субъектов инноваций и создание сетевого взаимодействия.

Укрепление и развитие 6 субъектов инноваций, включающих предприятия, вузы, научно-исследовательские институты, финансовые учреждения, посреднические организации, а также власти всех уровней, и формирование регионального механизма и сети инноваций между субъектами инноваций, выделяя инновацию в качестве главной цели.

Б. Программа создания региональной инновационной системы в 3 экономических районах: город Наньчан, юг центральной части провинции Цзянси и восточная часть провинции Цзянси.

В. Программа создания региональной инновационной системы, состоящей из 6 компонентов: инновации знаний, технологические инновации, посреднические службы, инвестирование и финансирование, охрана окружающей среды и политическая поддержка.

Г. Создание 8 программ инновационной системы:

- Программа инновационной системы 6 главных отраслей;

- Программа инновационной системы высокотехнологичной промышленности и новых технологий; 
- Программа инновационной системы индустриального парка;

- Программа инновационной системы района специализации;

- Программа инновационной системы промышленного кластера Цзиндэчжэнь (керамика);

- Программа инновационной системы интеграции военного и гражданского секторов (сотрудничество военно-промышленного комплекса и гражданского сектора);

- Программа инновационной системы сельского хозяйства;

- Программа инновационной системы проекта «Гора-река-озеро».

4.2. Развитие управления региональной инновационной системой.

А. Создание управляющей группы для развития региональной инновационной системы провинции Цзянси. Данная группа отвечает за построение наиболее эффективной, качественной и отвечающей самым последним современным требованиям региональной инновационной системы провинции, за разработку направлений и мер, за разработку планирования, за принятие плана реализации, за координацию организации и реализации и т.д. Штабквартира управляющей группы может относиться к Департаменту по науке и технологии провинции Цзянси; в обязанности данной группы входят, в частности, координация, мониторинг, организация, реализация и др.

Б. Создание экспертных комитетов по региональным инновациям. Комитет должен состоять из ведущих экспертов в главных промышленных отраслях и областях знаний. Кроме того, известные китайские и зарубежные ученые и эксперты также могут принимать участие в качестве консультантов на уровне презентации технологий и при принятии важных решений.
В. Разработка стратегии и плана развития науки и главных отраслей промышленности. Необходимо направить усилия на создание платформы технологической инновации и интеграции науки по всей провинции. Эти меры будут способствовать повышению эффективности основной программы взаимодействия промышленности и науки региона, направленной на развитие и поддержку быстрой интеграции науки во всех направлениях.

Г. Установление и совершенствование политики в области инвестиций в науку, налоговой политики, промышленности, талантов, государственной поддержки, интеллектуальной собственности и т.д.

4.3. Углубление реформирования научнотехнической сферы.

На основе развертывания деятельности правительства страны и правительства провинции Цзянси необходимо ускорить реформу системы прав собственности научно-исследовательских институтов, активно проводить реформу их финансирования. Это направит большинство исследовательских учреждений и научнотехнические кадры в главные экономические районы, что откроет новый путь через интеграцию науки, технологии и экономики.

4.4. Установление диверсифицированной системы инвестирования и финансирования.

Дальнейшие улучшения будут наблюдаться в диверсифицированной системе финансирования научно-технических инноваций, в которой координирующую роль играет государственная поддержка, ведущую роль - инвестиции предприятий; венчурный капитал выступает в качестве поддержки, а также активно осваивается социальный капитал и привлекается иностранный. Рынок капитала будет использоваться для поддержки и развития науки и образования, науки и промышленности, науки и социального развития, местной науки и промышленности, науки и капи- 
тала, науки и инвестиций в инфраструктуру, при поддержке всестороннего развития на различных уровнях.

4.5. Установление системы поддержки талантов.

А. Разработка и реализация всевозможных программ выявления, развития и поддержки талантов.

Б. Реализация бизнес-проектов зарубежных студентов.

В. Создание благоприятной среды для предпринимательства, инноваций и выявления талантов.

Г. Интенсивная подготовка высококвалифицированных и талантливых кадров.
4.6. Установление эффективного механизма для объединения производства и обучения с научными исследованиями и международным сотрудничеством.

A. Поддержка предприятий при строительстве исследовательских институтов и научно-технологических исследовательских центров.

Б. Развитие сотрудничества между промышленностью, университетами и научными институтами в рамках проекта индустриализации.

В. Ускорение технического инновационного прогресса средних и малых предприятий. 


\section{Теоретико-методологические основы формирования условий развития инновационных кластеров}

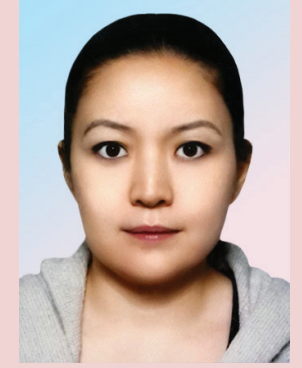

Анель Ахметовна

КИРЕЕВА

кандидат экономических наук, старший научный сотрудник, Институт экономики Комитета науки Министерства образования и науки Республики Казахстан (Казахстан, 050010, Алматы, ул. Курмангазы, 29, anele19@mail.ru)

Аннотация. В статье предлагаются методологические подходы к формированию условий для развития инновационных кластеров, направленные на структуризацию, оценку и стимулирование инновационных процессов. На основе данных подходов выделены эффективные условия формирования и развития «идеальных» инновационных кластеров.

Ключевые слова: кластер, инновационный кластер, региональная экономика.

Kireyeva A.A.

\section{Theoretical and methodological framework establishing the conditions for the development of innovation clusters}

Kireeva Anel' Akhmetovna - Ph.D. in Economics, Senior Research Associate, the Institute of Economics of the Committee for Science of the Ministry of Education and Science of the Republic of Kazakhstan (29, Kurmangazy Street, Almaty, 050010, Kazakhstan, anele19@mail.ru)

Abstract. The article proposes certain methodological approaches to the formation of conditions for the development of innovation clusters, aimed at the structuring, appraisal and promotion of innovation processes. The article highlights some efficient conditions for the formation and development of "ideal" innovation clusters on the basis of these approaches.

Key words: cluster, innovation cluster, regional economy. 
В настоящее время в научной среде все более широко признается, что регионы, на территории которых формируются кластеры, становятся лидерами технологического и экономического развития страны. Наличие таких регионов-лидеров определяет конкурентоспособность национальных экономик. Безусловно, в эффективно функционирующих кластерных структурах ускоряется технологический процесс, а у участников кластерного проекта развиваются такие преимущества, как восприимчивость к инновациям, усовершенствование бизнес-процессов и эффективный рост производительности труда. Кластеризация - объективный процесс, вызванный глобализационным процессом, стимулирующим рост международной конкуренции, в том числе за инвестиционные ресурсы, и возрастание сетевых, неформальных связей между субъектами. Кластеризация распространяется во всем мире, способствуя ускорению развития инновационно-технологических процессов в национальных экономиках.

Так, в Послании Президента Казахстана Н.А. Назарбаева народу «Стратегия "Казахстан-2050" - Новый политический курс состоявшегося государства» от 14 декабря 2012 г. поставлена цель «К 2050 году войти в число 30-ти самых развитых государств мира» [1]. Отметим, что ключевым инструментом реализации стратегии «Казахстан-2050» должен стать кластерный подход.

В свете этого особое значение приобретают правильный выбор места расположения строящихся объектов, научное обоснование наиболее рационального размещения инновационных технологий с точки зрения их обеспечения наименее мобильными трудовыми, материальными, природными ресурсами и достижения максимальной эффективности производства. Современный опыт развитых стран мира показывает, что эффективное экономическое развитие регионов в полной мере зависит от ориентированной системы взаимосвязанных факторов, среди которых географическое расположение и высококвалифицированный персонал играют немаловажную роль. При этом эффективный и динамичный рост получают те регионы, где сформировались именно инновационные кластеры как альтернатива традиционного отраслевого подхода. И наиболее активные и жизнеспособные кластеры формируются на основе диверсификации межотраслевых связей.

Феномен кластера как отраслевой агломерации на некоторой территории экономически взаимосвязанных предприятий известен со времен ремесленного производства. Однако только в последней четверти XX века промышленно-инновационные кластеры начали рассматриваться как важный фактор экономического развития регионов [2].

Так, главной характеристикой кластера является его инновационность. Он включает в себя всю инновационную цепочку от генерации научных знаний и формирования на их основе бизнес-идей до реализации товарной продукции на традиционных или новых рынках сбыта [3]. Кластерная структура приводит к созданию «совокупного инновационного продукта» - особой формы инновации [4]. Объединение в кластер на основе вертикально ориентированной интеграции формирует не просто концентрацию различных технологических и научных изобретений, а эффективную систему трансферта новых знаний и технологий. При этом важнейшим условием эффективной трансформации изобретений в инновации, а инноваций - в конкурентные преимущества является формирование сети устойчивых связей между всеми участниками кластера [5]. 
Для Казахстана кластерный подход является достаточно новым инструментом. Однако его использование начинает занимать одно из главных мест в стратегиях инновационного развития страны. На государственном уровне формируются механизмы, позволяющие обеспечить стимулирование и поддержку развития кластеров.

В целом надо отметить, что кластерная инициатива реализуется в соответствии с Посланием Главы государства народу Казахстана «K конкурентоспособному Казахстану, конкурентоспособной экономике, конкурентоспособной нации» от 19 марта 2004 года [6]. Основными целями казахстанской кластерной инициативы являются создание необходимых условий для максимального использования конкурентных преимуществ страны в целях развития несырьевого сектора экономики на основе вовлечения частных бизнес-структур и повышение конкурентоспособности отечественных предприятий.

Казахстан в своем развитии подошел к ситуации, когда настоятельно необходима диверсификация производства во избежание в дальнейшем зависимости от нефтяного сектора. Ожидаемое вступление в ВТО (Всемирная торговая организация) ставит страну перед необходимостью принимать неотложные меры инновационного и технологического характера. В таком контексте, без серьезных изменений, экономический рост будет приобретать экстенсивный характер, а способность предприятий противостоять конъюнктурным изменениям постепенно будет снижаться. В свете этого особую роль играет кластерная модель, которая стимулирует реализацию сравнительных преимуществ, превратив их в конкурентные преимущества.

Выделим пять основных теоретических концепций, поддерживающих кластерную теорию [7]:
- внешние экономии (external economies);

- инновационное окружение (innovation environment);

- конкурентная кооперация (cooperative competition);

- межфирменная конкуренция (rivalry);

- зависимость от пути (path dependence).

Отметим, что положения данных теорий непосредственно связаны с конкурентным ромбом Портера и, как факт, кластер усиливает конкурентные преимущества производителей [8, с. 92], повышая производительность процессов и ресурсов отдельного предприятия, формируя и локализуя специфические устойчивые источники его конкурентных преимушеств. Формирование кластера происходит в рамках единой институциональной среды при высокой степени специализации, сотрудничества и конкуренции. При этом, как отмечает М. Портер, в регионе должно быть не менее двух лидирующих отраслей, задействованных в технологической цепочке.

Однако М. Энрайт, ближайший последователь Портера, утверждает, что кластер формируют только конкурентоспособные предприятия. Он сделал предположение, что конкурентные преимущества создаются не на наднациональном или национальном уровне, а на региональном, где главную роль играют исторические предпосылки - развитие регионов, разнообразие культур ведения бизнеса, организации производства и получение образования [9]. Данные обстоятельства позволяют подвергнуть сомнению приемы адаптации кластерных технологий для их использования в Казахстане.

При этом существует ряд организационных проблем на пути формирования в стране инновационных кластеров, кото- 
рые обусловлены в первую очередь необходимостью усиления кооперации и взаимодействия организаций в рамках кластерных структур.

М. Портер к источникам конкурентоспособности в глобальной экономике относит четыре фактора:

1) технологические мощности;

2) доступ на крупный, интегрированный и богатый рынок;

3) разница между производственными издержками у производящей стороны и ценами на целевом рынке;

4) политические возможности национальных и межнациональных институтов управлять стратегиями роста стран и регионов, находящихся под их юрисдикцией [10, с. 205].

Становится очевидным, что эти источники и обеспечивают конкурентоспособность, поскольку представляют собой институциональные, производственные и экономические условия формирования кластеров.

В настоящий момент во многих странах кластерный поход используется для повышения конкурентоспособности национальной экономики. Так, европейские эксперты по наблюдению за развитием малых и средних предприятий после анализа различных типов кластеров и с помощью исследований М. Сторпера [11, с. 92] разработали схему развития «идеального» кластера, включающего в себя шесть стадий:

1) образование фирм-пионеров на основе местных специфических навыков производства, процесс раскручивания (spin-off);

2) создание системы поставщиков и специализированного рынка рабочей силы;

3) образование новых организаций (часто правительственных) для оказания поддержки фирмам;
4) привлечение в кластер внешних отечественных, затем и иностранных фирм, высококвалифицированной рабочей силы как стимулов для организации новых кластерных фирм;

5) создание неявных активов (знаний) между фирмами, которые стимулировали бы диффузию инноваций, информации и знаний;

6) возможный период упадка кластера из-за исчерпания своего инновационного потенциала, закрытости для внешних инноваций [12, с. 93-94].

При этом не все «идеальные» инновационные кластеры проходят шесть стадий развития: одни стадии, возможно, еще будут пройдены, а другие просто выпадают. При этом формирование любого «идеального» инновационного кластера требует высокого уровня взаимодействия и партнерских отношений между предприятиями, государством, научно-исследовательскими и общественными организациями. Каждая из организаций может являться важным инструментом в процессе создания кластера и способна эффективно исполнять свои функции и задачи только в составе хорошо отлаженного синергетического механизма - совокупности функциональных элементов в виде отдельных подсистем, наделенных специфическими инструментами, позволяющими реализовать функции этого механизма.

Мировая практика показывает, что развитые страны находятся на стадии освоения инновационных преимуществ, а остальные - в основном на стадии факторных и частично инвестиционных с точки зрения привлекательности, например Китай. Стратегия ориентированности на мировой рынок дает возможность развивающимся странам использовать своеобразное «преимущество отсталости». Переход же к технологическим конкурентным преимуществам требует от 
правительства координации инвестиций в технологии с развитием «человеческого капитала», его объективной многоплановой оценкой [13]. Здесь в нашей стране большие проблемы, связанные с уменьшением финансирования фундаментальной науки, а также проведением реформ в системе образования.

Наиболее успешные инновационные кластеры формируются там, где есть возможности для отлаженного синергетического механизма в области прорывных технологий с последующим выходом на глобальные рынки. Так, объединенные группы, участвующие в кластере на основе вертикальной интеграции, формируют не спонтанную концентрацию разнообразных технологических новшеств, а строго ориентированную систему трансферта новых знаний и инноваций.

Одним из наиболее успешных примеров формирования инновационных кластеров на основе отлаженного взаимодействия в пределах одного региона является опыт Германии. Отраслевые и межотраслевые сети компаний, созданные в рамках федеральной земли Северный РейнВестфалия (North Rhine-Westphalia), позволяют региональным властям формировать собственный международный бренд под оригинальным названием «Exzellenz NRW», считая его частью общей стратегии позиционирования региона для привлечения инвестиций.

Согласно официальной позиции Министерства экономики и энергетики земли Северный Рейн-Вестфалия, курирующего данный проект, «кластерная политика принята для стимулирования экономического роста и трансформации промышленности в креативную экономику» [14, с. 20]. Инновационные кластеры этой территории призваны инициировать творческие процессы и формировать для этой цели тесные союзы взаимодополня- ющих предприятий, научных организаций и таких ассоциированных участников, как кредитные и образовательные учреждения.

Поэтому «идеальные» инновационные кластеры создают условия для привлечения инвестиционных ресурсов, способствуют росту деловой активности предпринимательских структур, развитию социальных, экономических, информационных и интегрированных систем, что, в свою очередь, дает импульс к повышению конкурентоспособности национальной экономики.

В этой связи предлагаем поэтапную методологию создания и развития инноваиионных кластеров, представляющую собой порядок реализации взаимосвязанных процедур, позволяющих сформировать кластерное образование.

На наш взгляд, поэтапное создание инновационных кластеров должно основываться на методологических подходах, которые обеспечивают сокращение организационных проблем в области формирования кластеров:

- процессный подход - позволяет создать базу для структуризации технологических процессов и формирования системы управления ими, включающей контроль за исполнением и эффективностью организации процессов;

- ресурсный подход - направлен на оценку и выявление ресурсов, требуемых для эффективной реализации функций, возложенных на инновационные кластеры, и их потенциала;

- результативно-ориентированный подход - обеспечивает работу контрольного механизма, позволяющего оценить степень достижения цели формирования инновационного кластера и задающего вектор развития, а также содействующего интеграции всех структурных элементов кластера для реализации общих стратегических задач; 
- инновационный подход - стимулирует развитие инновационных процессов и формирует способность кластера оптимально использовать совокупные ресурсы и знания.

На основе вышеназванных методологических подходов предлагаем выделить эффективные условия формирования и развития «идеальных» инновационных кластеров:

- наличие научного потенциала, т.е. научно-исследовательских институтов и центров, вузовской и заводской (производственной) науки;

- наличие институциональных предпосылок, которые могут выделиться на основе кластерного подхода, - государственная поддержка идеи формирования инновационного кластера, возможно, в рамках наиболее приоритетной отрасли;

- наличие политических предпосылок, которые проявляются в решимости руководства развивать инновационную деятельность в качестве одного из стратегических приоритетов развития;

- наличие социальных предпосылок, которые связаны с социальным взаимодействием внутри кластера, а также наличие человеческих ресурсов;

- наличие производственных предпосылок, а именно уровень инновационности промышленности региона в целом и отдельных предприятий, входящих в кластер;

- наличие экономических предпосылок, которые проявляются в наличии конкурентоспособных предприятий, способных привлечь дополнительный инвестиционный и заемный капитал.

Следовательно, кластерная структура организации инновационной деятельности приводит к созданию инновационного продукта. Такая инновация является продуктом совместной деятельности хозяйствующих субъектов, что позволит ускорить их распространение по взаимосвязанной сети в общем региональном экономическом пространстве. Кроме того, разнообразие различных источников технологических знаний и связей облегчает комбинацию факторов достижения конкурентных преимуществ и становится предпосылкой инновации. Объединение в инновационный кластер на основе вертикально ориентированной интеграции формирует не спонтанную концентрацию разнообразных технологических изобретений, а сконцентрированную систему распространения и внедрения новых технологий.

При этом инновационный кластер, как наиболее эффективный инструмент повышения конкурентоспособности, представляет собой синергетический механизм усилий различных организаций - промышленных предприятий, научно-исследовательских центров, государственных органов, высших учебных заведений и общественных организаций.

Система взаимоотношений между участниками инновационного кластера является сложной по своей природе и должна включать в себя правовой, организационный, экономический, инновационный, информационный и прочие механизмы. Поэтому необходимо уделять особое внимание данному процессу сопряжения интересов участников кластера. На наш взгляд, рассматривать интересы предприятия следует с позиций его взаимодействия с субъектами внешней среды, осуществляемого постоянно или в течение определенного промежутка времени, вынужденно или по выбору предприятия и обеспечивающего получение прибыли.

В этой связи эффективные условия формирования инновационных кластеров должны заключаться прежде всего в создании устойчивого пространственного 
каркаса разнообразных структурных кластерных зон опережающего (инновационного) развития, способных транслировать инновации на обширную периферию страны. Таким образом, «идеальные» инновационные кластеры создают условия для привлечения инвестиционных ресурсов, способствуют росту деловой активности предпринимательских структур, развитию социальных, экономических, информационных и интегрированных систем, что, в свою очередь, дает импульс к повышению конкурентоспособности национальной экономики. Именно такой подход обеспечивает эффективную трансформацию изобретений в инновации, а инноваций - в конкурентные преимущества кластера.

\section{Литература}

1. Послание Президента Республики Казахстан - лидера нации Н.А. Назарбаева народу Казахстана «Стратегия “Казахстан-2050” - Новый политический курс состоявшегося государства» 14 декабря 2012 г.

2. Гибеж, А.А. Деревянное домостроение как основа кластера / А.А. Гибеж // Проблемы стратегии и тактики регионального развития: материалы V Российской науч.-практ. конф., г. Вологда, 25-27 января 2006 г. - Часть II. - Вологда: ВНКЦ ЦЭМИ РАН, 2006. - 436 с.

3. Бирюков, А.В. Преимущества современных инновационных кластеров / А.В. Бирюков // Сайт «Морские вести». - 2009. - Режим доступа: http: www.morvesti.ru

4. Мигранян, А.А. Теоретические аспекты формирования конкурентоспособных кластеров в странах с переходной экономикой / А.А. Мигранян // Вестник КРСУ. - 2002. - №3.

5. Ялов, Д.А. Кластерный подход как технология управления региональным экономическим развитием / Д.А. Ялов // Сайт журнала «Компас промышленной реструктуризации». - 2007. - Режим доступа: http:www.compass-r.ru/st.html

6. Послание Президента страны Н.А. Назарбаева, лидера нации, народу Казахстана «К конкурентоспособному Казахстану, конкурентоспособной экономике, конкурентоспособной нации» 19 марта 2004 г.

7. Bergman, E.M. Industrial and Regional Clusters: Concepts and Comparative Applications. Web Book of Regional Science / West Virginia University [Electronic resource]. - Mode of access: http://www. rri.wvu.edu/ WebBook/ Bergman-Feser

8. Портер, М. Международная конкуренция / М. Портер; пер. с англ. под ред. и с предисл. В.Д. Щетинина. М.: Международные отношения, 1993. - 896 с.

9. Enright, M.J. Survey on the Characterization of Regional Clusters: Initial Results. Working Paper [Electronic resource] / Michael J. Enright, Sun Hung Kai, 2000.

10. Портер, М. Конкуренция: пер. с англ. / М. Портер. - М.: Вильямс, 2000. - 495 с.

11. Storper M., Walker R. The capitalist imperative. Territory technology and industrial growth. - New York: Basil Blackwell. - 1989.

12. Пилипенко, И.В. Конкурентоспособность стран и регионов в мировом хозяйстве: теория, опыт малых стран Западной и Северной Европы / И.В. Пилипенко. - Смоленск: Ойкумена, 2005. - 496 с.

13. Соколов, Б.И. Финансовое измерение человеческого капитала в России / Б.И. Соколов // Проблемы современной экономики. - 2010. - №4. - С. 53-56.

14. Северный Рейн-Вестфалия 2015 года. Доклад Совета NRW // Сайт http://www.factor10-institute.org/files/ NRW_2015_e.pdf

\section{References}

1. Poslanie Prezidenta Respubliki Kazakhstan - lidera natsii N.A. Nazarbaeva narodu Kazakhstana "Strategiya “Kazakhstan-2050” - Novyy politicheskiy kurs sostoyavshegosya gosudarstva” 14 dekabrya 2012 g. [Address of the President of the Republic of Kazakhstan, Leader of the Nation, Nursultan Nazarbayev to the People of Kazakhstan "The Strategy "Kazakhstan 2050": New Political Course of the Established State" on December 14, 2012]. 
2. Gibezh A.A. Derevyannoe domostroenie kak osnova klastera [Wooden Housing Construction as a Basis for Cluster]. Problemy strategii i taktiki regional'nogo razvitiya: materialy V Rossiyskoy nauch.-prakt. konf., g. Vologda, 25-27 yanvarya $2006 \mathrm{~g}$. Chast' II [Issues of Strategy and Tactics of Regional Development: Proceedings of the 5th Russian Research-to-Practice Conference, Vologda, January 25-27, 2006. Part 2]. Vologda: VSCC CEMI RAS, 2006.

3. Biryukov A.V. Preimushchestva sovremennykh innovatsionnykh klasterov [Advantages of Modern Innovation Clusters]. Maritime News of Russia. Available at: http: www.morvesti.ru

4. Migranyan A.A. Teoreticheskie aspekty formirovaniya konkurentosposobnykh klasterov v stranakh s perekhodnoy ekonomikoy [Theoretical Aspects of Formation of Competitive Clusters in Transition Economies]. Vestnik KRSU [Bulletin of Kyrgyz-Russian Slavic University], 2002, no.3.

5. Yalov D.A. Klasternyy podkhod kak tekhnologiya upravleniya regional'nym ekonomicheskim razvitiem [Cluster Approach as a Technology of the Regional Economic Development Management]. Kompas promyshlennoy restrukturizatsii [Compass of Industrial Restructuring], 2007. http:www.compass-r.ru/st.html

6. Poslanie Prezidenta strany N.A. Nazarbaeva, lidera natsii, narodu Kazakhstana “K konkurentosposobnomu Kazakhstanu, konkurentosposobnoy ekonomike, konkurentosposobnoy natsii” 19 marta $2004 \mathrm{~g}$. [Address of the President of the Republic of Kazakhstan, Leader of the Nation, Nursultan Nazarbayev to the People of Kazakhstan "To the Competitive Kazakhstan, Competitive Economy, Competitive Nation" on March 19, 2004].

7. Bergman E.M. Industrial and Regional Clusters: Concepts and Comparative Applications. Web Book of Regional Science. West Virginia University. Available at: http://www. rri.wvu.edu/ WebBook/ Bergman-Feser

8. Porter M. Mezhdunarodnaya konkurentsiya [The Competitive Advantage of Nations]. Translated from English and edited by V.D. Shchetinin. Moscow: Mezhdunarodnye otnosheniya, 1993.

9. Enright M. J., Sun Hung Kai. Survey on the Characterization of Regional Clusters: Initial Results. Working Paper. 2000.

10. Porter M. Konkurentsiya [On Competition]. Translated from English. Moscow: Vil'yams, 2000.

11. Storper M. Walker R. The Capitalist Imperative. Territory Technology and Industrial Growth. New York: Basil Blackwell, 1989.

12. Pilipenko I.V. Konkurentosposobnost' stran i regionov v mirovom khozyaystve: teoriya, opyt malykh stran Zapadnoy i Severnoy Evropy [Competitiveness of Countries and Regions in the World Economy: Theory, Experience of Small Countries of Western and Northern Europe]. Smolensk: Oykumena, 2005.

13. Sokolov B. I. Finansovoe izmerenie chelovecheskogo kapitala v Rossii [Financial Dimension of Human Capital in Russia]. Problemy sovremennoy ekonomiki [Problems of Modern Economics], 2010, no.4, pp. 53-56.

14. North Rhine-Westphalia 2015. Report of the Council of NRW. Available at: http://www.factor10-institute.org/ files/NRW_2015_e.pdf 


\section{МОДЕЛИРОВАНИЕ И ИНФОРМАТИКА}

УДК 338.27:330.42, ББК 65.23

(С) Садов С.Л.

\section{Использование надмедианных рангов \\ для сравнения альтернатив на долгосрочную перспективу регионального развития}

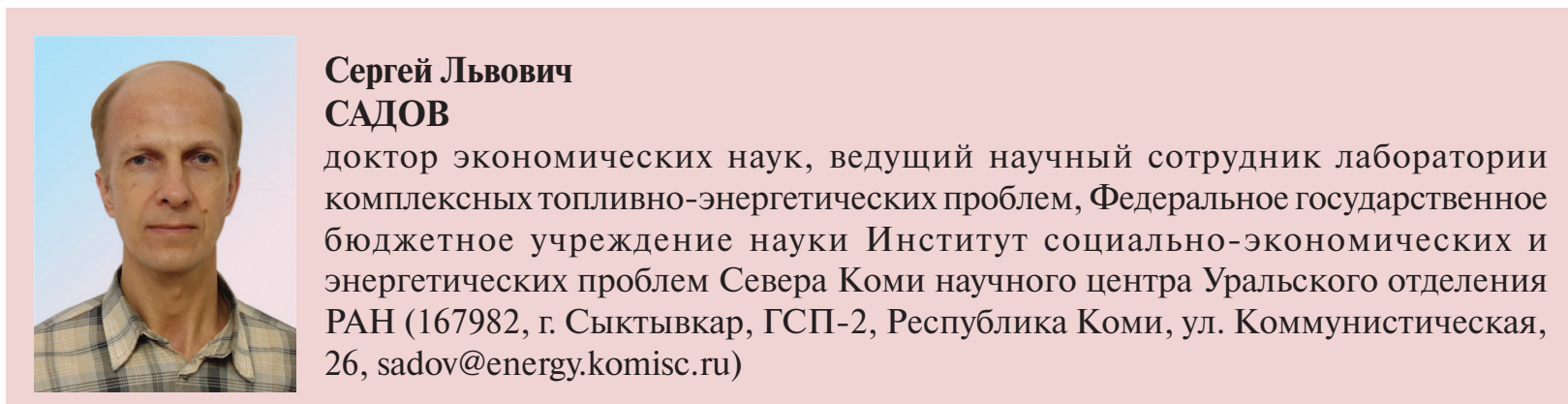

Аннотация. В статье предлагается авторский подход к сравнению альтернатив долгосрочного развития системы/объекта, основанный на использовании порядковых переменных. Сравнение и выбор лучшей альтернативы проводится авторским методом надмедианных рангов. Применение предлагаемого подхода иллюстрируется при выборе варианта развития экономики Республики Коми.

Ключевые слова: альтернативы долгосрочного развития системы/объекта, метод надмедианных рангов, порядковые переменные.

Sadov S.L.

\section{The use of median rank for the comparison of alternatives in the long-term}

Sadov Sergey L'vovich - Doctor of Economics, Leading Research Associate, Laboratory for Complex Fueland-Energy Issues, the Institute of Socio-Economic and Energy Problems of the North Komi Science Centre, Ural Branch of RAS (26, Kommunisticheskaya Street, Syktyvkar, 167982, Russia, sadov@energy.komisc.ru)

Abstract. The article offers the author's approach to the comparison of the alternatives for the long-term development of the system/object, based on the use of ordinal variables. The best alternative is compared and selected using the author's method of supramedian ranks. The article illustrates the application of the proposed approach when choosing the option of economic development of the Komi Republic.

Key words: alternatives for the long-term development of the system/object, supramedian rank method, ordinal variables. 
Прогнозировать социально-экономические процессы на долгосрочную перспективу, оценивать варианты их динамики и давать рекомендации по их выбору приходится в условиях высокой неопределённости. Это вызвано большим горизонтом прогнозирования и, как следствие, высокой неопределённостью внешних условий среды, в которой происходит развитие и функционирование прогнозируемого объекта (системы), а также низкой достоверностью многих исходных данных.

Социально-экономические системы, как правило, отличаются высокой сложностью, что влечёт большую и принципиально неустранимую неопределённость при определении динамики их развития. Поэтому типична ситуация, когда при моделировании экономических систем и процессов важной частью информационного обеспечения моделей служат экспертные оценки. Причём желательно свести к минимуму получаемые от экспертов конкретные количественные оценки, которые на долгосрочную перспективу заведомо неточны и могут дезориентировать исследователя. Целью автора была разработка метода выбора наилучшей альтернативы развития объекта/системы на основе анализа совокупности экспертных качественных оценок, не ограничивающегося группированием альтернатив по предпочтительности, а позволяющего по максимуму дифференцировать их.

При работе над проблемой учёта неопределённости при экономической оценке нефтегазовых ресурсов ранее нами были использованы средства теории нечётких множеств. Они хорошо подошли к задачам моделирования геологических объектов и нефтегазоносных территорий и проблемам получения оценок экономической ценности ресурсов углеводородов [1]. Так ли хорошо будут обстоять дела с задачами долгосрочного прогнозирования соци- ально-экономических процессов, остаётся неясным. Например, построение одного из важнейших инструментов теории нечётких множеств - функции принадлежности - в каждой конкретной задаче требует особых подходов и учёта отраслевой специфики. Поэтому оказалось полезным обратиться к другим возможностям, которые предоставляет математика для прогнозирования в условиях неопределённости.

В этих целях наряду с нечеткими переменными нашли широкое применение номинативные (nominative variable), порядковые (ordinal variable), интервальные (interval variable) переменные и переменные отношений (ratio variable). Они перечислены в порядке повышения информативности и в этом же порядке возрастают требования к исходной информации. В этом перечне привлекают внимание порядковые переменные. Это тип дискретной переменной величины, качественной по своему характеру, используемой для обозначения порядковых или ранговых показателей. Они выражаются численно в баллах или вербально в виде градаций лингвистической шкалы (которые также легко переводятся в количественные показатели). К информационному обеспечению они нетребовательны - достаточно упомянутых выше экспертных оценок. Примеры использования порядковых переменных в задачах прогнозирования и управления встречаются у Т. Саати [2], Я.И. Хургина [3], во многих работах, посвященных социологической, психологической и лингвистической тематикам. Нет сколько-нибудь серьёзных препятствий для применения их при решении задач экономического прогнозирования качественного характера.

Подобный подход реализован в известном методе медиан рангов [4]. Хотя пользователь данного метода будет вынужден признавать равноценными несколько альтернатив и объединять их в один кластер. 
Формально это правомерно. Но в содержательном аспекте решаемой задачи это нонсенс: альтернативы долгосрочного развития должны представлять существенно различные пути развития изучаемой системы, поэтому следует не смешивать их, а добиваться выделения из них наилучшей. Именно достижению этой цели служит предлагаемый метод надмедианных рангов (НР).

Рассмотрим формализованную постановку задачи сравнения нескольких альтернатив развития объекта/системы, в роли которых может фигурировать регион, сектор или отрасль его экономики или отдельный хозяйствующий субъект. Цель исследователя - выявление альтернативы, имеющей наилучшие условия для реализации, посредством сравнения.

На первом этапе (аналитическом) экспертным путём определяются, с одной стороны, альтернативы - существенные варианты развития объекта/системы, они должны исчерпывать основные возможности и при этом значительно отличаться друг от друга. Определяются также $m$ факторов, влияющих на развитие объекта/системы. По своему характеру факторы могут быть самыми различными экономическими, энергетическими, социальными, инвестиционными, экологическими, институциональными, демографическими, транспортными и иными, главное, чтобы их влияние было признано существенным.

Далее по каждой из альтернатив следует присвоение ранга каждому фактору, который будет характеризовать его достаточность, способность поддержать, обеспечить развитие объекта/системы сообразно данной альтернативе, и проведение на основе полученного множества рангов выбора наилучшей альтернативы. Поскольку факторы будут иметь различную природу и размерность, их следует свести к единой шкале рангов, состоящей, как правило, из 5 или 9 градаций. Рассмотрим широко используемую шкалу, состоящую из девяти градаций [2]. Для рассматриваемой задачи:

- ранг 1 будет означать отличную, самую высокую степень способности фактора обеспечить рассматриваемую альтернативу развития;

- ранг 3 - хорошую;

- ранг 5 - удовлетворительную;

- ранг 7 - плохую;

- и ранг 9 - полную неспособность.

Чётные ранги от 2 до 8 выражают промежуточные состояния. Таким образом устанавливается связь между количественными величинами рангов и их вербальным описанием как лингвистической переменной [5]. Если будет представлять трудность выделение чётных рангов для какого-либо фактора, то для него придётся использовать шкалу из 5 нечётных градаций. Это приведёт к меньшей «разрешающей способности» данного фактора, но сути метода не изменит. Анализ полученной матрицы факторов укажет на узкие места в реализации той или иной альтернативы.

На втором этапе (алгоритмическом) оценки альтернатив и выводы о преимуществе какой-либо из них проводятся методом надмедианных рангов. Очевидно, что если у какой-либо альтернативы все ранги наилучшие, то выбрать следует именно её. Но такая ситуация представляется редким исключением. Обычно имеет место «разноголосица» при оценке факторов. В таком случае из совокупности рангов, приписанных альтернативе, выделяется множество надмедианных рангов. Здесь решающую роль сыграет то соображение, что драйверов реализации того или иного варианта развития не может и не должно быть слишком много вполне достаточно, если это будет абсолютное большинство факторов от общего их числа. 
Надмедианными будем считать ранги, лучшие либо равные медианному. Они должны составлять абсолютное большинство среди рангов, участвующих в оценке альтернатив, т.е. их количество будет не меньше $m^{\prime}$, где

$$
m^{\prime}=\left\{\begin{array}{l}
\frac{m}{2}+1, \text { если } m-\text { чётноечисло } \\
\frac{m+1}{2}, \text { если } m-\text { нечётно. }
\end{array}\right.
$$

Другими словами, надмедианные ранги - это $m^{\prime}$ рангов, стоящих в начале ряда, ранжированного от наилучшего к худшему. До этого момента описываемый метод напоминает метод медианы рангов [4]. Но дальнейший ход действий существенно отличен.

Как правило, выясняется, что на первом этапе многие альтернативы имеют одинаковый медианный ранг (МР). Тогда, чтобы дифференцировать их детальнее, следует применить другие критерии, используемые в методе (рисунок): для альтернатив с одинаковым МР подсчитывается количество надмедианных рангов (КНР), и чем больше КНР у альтернативы, тем она должна быть предпочтительнее.

При необходимости, если у каких-либо альтернатив и КНР будет одинаково, следует обратить внимание на структуру надмедианных рангов - чем больше среди них высоких рангов, тем структура лучше. Это выявляется таким критерием, как сумма НР (СНР). Чем меньше СНР у альтернативы, тем её оценка в итоге выше. Здесь следует обратить внимание на одну тон- кость - на условность операции суммирования. Ведь в принципе ранги не обязательно должны выражаться числами (хотя так привычнее и удобнее). Допустимы буквенные и вообще любые пиктографические изображения - главное, чтобы на их множестве был определён порядок. В этом случае введение операции суммирования на множестве используемых символов в принципе возможно, но это хлопотная и не имеющая практического резона работа. Поэтому суммирование на данном этапе алгоритма важно не само по себе, а именно как средство отражения, качественного анализа и количественной оценки структуры надмедианных рангов, имеющихся у альтернативы.

Последней попыткой дифференцировать альтернативы, если все предыдущие показатели окажутся одинаковы, станет вычисление суммы всех рангов (СР) - т.е. учитывается структура всей совокупности рангов, полученных альтернативой. И только в случае, если и здесь будет иметь место равенство, альтернативы следует признать равноценными и проводить окончательный выбор, привлекая иные соображения. Возможно, следует вернуться к исходным данным и проверить правомерность наделения факторов значениями рангов, которые были присвоены им первоначально. Последовательность критериев, применяемых по мере необходимости (см. рисунок), позволяет говорить об использовании расширенного понятия медианного ранга, его обобщения. Отсюда и проистекает название метода НР.

Последовательность использования критериев в методе надмедианных рангов

\begin{tabular}{|c|c|c|c|}
\hline $\begin{array}{c}\text { Медианный } \\
\text { ранг } \\
\text { (MP) }\end{array}$ & $\begin{array}{c}\text { Количество надмедианных } \\
\text { рангов } \\
\text { (КНP) }\end{array}$ & $\begin{array}{c}\text { Сумма надмедианных } \\
\text { рангов } \\
\text { (CHP) }\end{array}$ & $\begin{array}{c}\text { Сумма всех } \\
\text { рангов } \\
\text { (CP) }\end{array}$ \\
\hline
\end{tabular}


Пример. Пусть рассматриваются 4 альтернативы развития объекта/системы и по итогам анализа отобрано 7 факторов, при использовании шкалы с 9 градациями подготовлены следующие исходные данные (табл. 1).

Процесс определения медианного ранга на примере первой альтернативы выглядит следующим образом. Поскольку факторов 7 , то в соответствии с формулой $m^{\prime}=4$. Среди множества рангов, имеющихся у данной альтернативы, отыскивается самый высокий - в данном случае это ранг 2. Может ли он быть медианным? Нет, поскольку он только один, а $1<m^{\prime}$. Далее рассматривается, не является ли медианным следующий ранг - в данном случае 3. Тоже нет, поскольку количество третьих и более лучших рангов равно $2<m^{\prime}$. Ранг 4 вместе с лучшими тоже не составляет большинства, поэтому медианным быть не может. И только ранг 5 является медианным. Аналогичным образом находятся медианные ранги для альтернатив со 2-й по 4-ю и для всех них он оказывается равным 4. Если бы какая-то одна альтернатива имела наивысший медианный ранг, то она была бы признана наилучшей и на этом работа метода закончилась бы. Но в данном примере наивысший МР имеется сразу у трёх альтернатив (заметим, что по методу медианы рангов их следует скопом зачислить в один кластер), поэтому к этой группе применяется второй критерий - количество надмедианных рангов. Поскольку для всех альтернатив это количество равно 4, выбор сделать нельзя, и в действие вступает следующий критерий - сумма надмедианных рангов. Эта сумма для «альтернативы-2» равна $4+2+4+3=13$, для третьей $-1+4+4+2=11$, для четвёртой равна $3+2+4+2=11$. Для двух последних альтернатив с лучшими значениями критерия СНР они оказались равными, поэтому к ним необходимо применить последний критерий - сумму рангов, значение которой для «альтернативы-3» равно 32, а для «альтернативы-4» - 29. В результате «альтернатива-4» является наилучшей и на этом работа метода надмедианных рангов заканчивается.

Обратимся к конкретной задаче оценки и выбора альтернатив развития экономики Республики Коми на долгосрочную перспективу. Для республики можно выделить 4 (за исключением консервативно-инерционной) следующие альтернативы, перспективные в плане социально-экономического развития региона $[6,7]$ : № 1 - углубление сырьевой специализации, №2 - ставка на рост переработки сырья с высокой добавленной стоимостью, №3 - создание новых отраслей, №4 - инновационная. На возможности их реализации будут влиять как минимум 6 факторов: инвестиционный, технологический, кадровый, транспортный, институциональный, экологический (именно в таком порядке они включены в табл. 2), поэтому $m^{\prime}=4$.

Для присвоения рангов альтернативам по какому-либо из факторов необходимо сначала проанализировать, насколько существен данный фактор для реализации альтернатив, оценив при этом его влияние, а затем соотнести это влияние с 9-балльной шкалой рангов.

Таблица 1. Пример определения наилучшей альтернативы по методу НР

\begin{tabular}{|c|c|c|c|c|c|c|c|c|c|c|c|}
\hline \multirow{2}{*}{ Альтернатива } & \multicolumn{7}{|c|}{ Фактор } & \multirow{2}{*}{ MP } & \multirow{2}{*}{ KHP } & \multirow{2}{*}{ CHP } & \multirow{2}{*}{$\mathrm{CP}$} \\
\hline & $1-\breve{и}$ & $2-\breve{и}$ & $3-\breve{~}$ & 4-й & $5-\breve{и}$ & $6-\check{и}$ & $7-\check{и}$ & & & & \\
\hline Альтернатива-1 & 5 & 2 & 7 & 6 & 3 & 6 & 4 & 5 & & & \\
\hline Альтернатива-2 & 4 & 7 & 5 & 2 & 4 & 3 & 6 & 4 & 4 & 13 & \\
\hline Альтернатива-3 & 1 & 7 & 4 & 6 & 4 & 2 & 8 & 4 & 4 & 11 & 32 \\
\hline Альтернатива-4 & 3 & 6 & 2 & 4 & 2 & 7 & 5 & 4 & 4 & 11 & 29 \\
\hline
\end{tabular}


Таблица 2. Факторная матрица для задачи выбора альтернативы развития экономики Республики Коми

\begin{tabular}{|c|c|c|c|c|c|c|c|c|c|c|}
\hline \multirow{2}{*}{ Альтернатива } & \multicolumn{6}{|c|}{ Фактор } & \multirow{2}{*}{ MP } & \multirow{2}{*}{ KHP } & \multirow{2}{*}{ CHP } & \multirow{2}{*}{$\mathrm{CP}$} \\
\hline & 1-й & $2-\breve{и}$ & $3-и ̆$ & 4-й & $5-\breve{~}$ & 6-й & & & & \\
\hline № 1 & 6 & 2 & 3 & 7 & 4 & 8 & 6 & - & - & - \\
\hline № 2 & 3 & 4 & 3 & 5 & 3 & 6 & 4 & - & - & - \\
\hline № 3 & 4 & 5 & 5 & 5 & 5 & 5 & 5 & - & - & - \\
\hline № 4 & 3 & 7 & 6 & 3 & 2 & 2 & 3 & - & - & - \\
\hline
\end{tabular}

Так, например, инвестиционный фактор наиболее неблагоприятен для альтернативы №1, поскольку часть ТиманоПечорской нефтегазоносной провинции, приходящаяся на Республику Коми, содержит в основном месторождения, находящиеся на стадии падающей добычи, и прогнозные ресурсы с проблематичной локализацией, и поэтому она не представляет большого интереса для крупных нефтяных компаний (имеющих большие инвестиционные возможности). Мелкие же компании не располагают инвестиционными ресурсами, достаточными для проведения поисково-разведочных работ и освоения потенциала малоизученных территорий провинции. Очень капиталоёмким является также освоение ресурсов угля.

Менее инвестиционный фактор значим для альтернативы №3 и еще меньше (примерно в равной степени) - для №2 и 4. Исходя из этих соотношений, выбираем на 9-балльной шкале соответствующие наиболее близкие числовые градации сообразно их лингвистическим значениям. В результате выбраны количественные значения баллов, равные соответственно 6, 4, 3 и 3. Аналогично и для остальных факторов. Придание процедуре назначения численных значений рангов по возможности более объективного характера посредством её унификации и формализации видится важным направлением развития описанного метода.

Итак, факторная матрица имеет вид (см. табл. 2). Заметно, что уже на первом этапе метода НР выявляется наиболее перспективная в реализации альтернатива - №4.

В заключение необходимо отметить, что для более углублённой проработки прогнозов полезно не рассматривать метод НР изолированно от экономических оценок, хотя бы и сугубо ориентировочных, какие получаются при долгосрочном прогнозировании. Допустим, какая-то альтернатива (№2, углубление переработки сырья) признаётся самой желательной для успешного социально-экономического развития республики. Тогда полезно будет сопоставить затраты на расшивку узких мест этой альтернативы (в данном случае речь идёт о 2-м и 4-м факторах, которые придётся подтянуть до ранга 3) с положительными последствиями её реализации. Иными словами, следует определить, стоит ли бороться за эту конкретную альтернативу или лучше ориентироваться на ту, которая более отвечает сложившимся условиям. Одним из направлений совершенствования изложенного метода может стать учёт неравнозначности факторов, по которым проводится оценка реализуемости альтернатив, - для случаев, когда есть уверенность в превалировании каких-либо факторов на весь период прогнозирования.

\section{Литература}

1. Садов, С.Л. Методы оценки нефтегазового потенциала территорий / С.Л. Садов. - Сыктывкар: Изд-во КНЦ УрО РАН, 2007. - 248 с. 
2. Саати, Т. Принятие решений: метод анализа иерархий / Т. Саати. - М.: Радио и связь, 1993. - 280 с.

3. Хургин, Я.И. Проблемы неопределённости в задачах нефти и газа / Я.И. Хургин. - Москва-Ижевск: Институт компьютерных исследований, 2004. - 320 с.

4. Орлов, А.И. Эконометрика / А.И. Орлов. - М.: Изд-во «Экзамен», 2002. - 576 с.

5. Заде, Л. Понятие лингвистической переменной и его применение к принятию приближенных решений / Л. Заде. - М.: Мир, 1976. - 165 с.

6. Энергоэкономическое прогнозирование развития региона / отв. ред. чл.-корр. РАН В.Н. Лаженцев. М.: Наука, 2008. - 356 c.

7. Инновационное развитие топливно-энергетических систем Севера / отв. ред. О.В. Бурый. Сыктывкар: Изд-во КНЦ УрО РАН, 2011. - 244 с.

\section{References}

1. Sadov S.L. Metody otsenki neftegazovogo potentsiala territoriy [Methods for Assessing Oil and Gas Potential of the Territories]. Syktyvkar: KNTs UrO RAN Publ., 2007. 248 p.

2. Saati T. Prinyatie resheniy: metod analiza ierarkhiy [Decision-Making: Analytic Hierarchy Process]. Moscow: Radio i svyaz', 1993. 280 p.

3. Khurgin Ya.I. Problemyneopredelennosti vadachakh nefti igaza [Problems of Uncertainty in Oil and Gas Issues]. Moscow-Izhevsk: Institut komp'yuternykh issledovaniy, 2004. 320 p.

4. Orlov A.I. Ekonometrika [Econometrics]. Moscow: "Ekzamen” Publ., 2002. 576 p.

5. Zadeh L. Ponyatie lingvisticheskoy peremennoy i ego primenenie k prinyatiyu priblizhennykh resheniy [The Concept of a Linguistic Variable and Its Application to Approximate Reasoning]. Moscow: Mir, 1976. 165 p.

6. Energoekonomicheskoe prognozirovanie razvitiya regiona [Energy and Economic Forecast of the Region's Development]. Executive Editor: RAS Corresponding Member V.N. Lazhentsev. Moscow: Nauka, 2008. 356 p.

7. Innovatsionnoe razvitie toplivno-energeticheskikh sistem Severa [Innovation Development of Fuel and Power Systems of the North]. Executive Editor: O.V. Buryi. Syktyvkar: KNTs UrO RAN Publ., 2011. 244 p. 


\section{МОЛОДЫЕ ИССЛЕДОВАТЕЛИ}

УДК 331.101.262(470.12), ББК 65.240(2Рос-4Вол)

(C) Попов A.B.

\section{Оценка результативности трудового поведения населения на макроуровне}

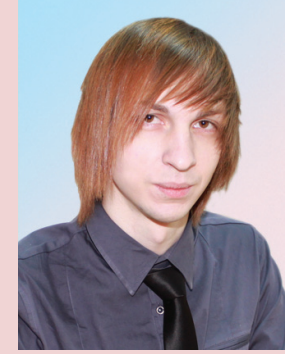

Андрей Васильевич

ПОПОВ

младший научный сотрудник отдела исследования уровня и образа жизни населения, Федеральное государственное бюджетное учреждение науки Институт социально-экономического развития территорий Российской академии наук (ai.popov@уahoo.com, 160014, Россия, г. Вологда, ул. Горького, д. 56а)

Аннотация. В статье рассмотрены основные подходы к исследованию результативности трудового поведения населения. Особое внимание уделено анализу статистических, социологических и статистико-социологических методик. Представлена авторская методика, позволяющая проанализировать результативность трудового поведения по сферам проявления: на рынке труда и в организации. Показана значительная дифференциация по этому показателю российских территорий. Наиболее высоким он был в Уральском (0,588 ед.) и Центральном (0,422 ед.) федеральных округах, наименьшим - в Сибирском (-0,139 ед.) и Северо-Кавказском (-1,269 ед.). Проведена интегральная оценка результативности трудового поведения населения, по этому критерию выделено 5 групп регионов РФ в зависимости от уровня показателя. По результатам анализа определено, что к территориям с высоким уровнем рассматриваемого показателя относятся такие субъекты Центрального федерального округа, как г. Москва и Московская область. Большинство субъектов РФ входят в группу с уровнем выше среднего. К группе со средним уровнем относятся регионы, входящие в состав практически всех округов (за исключением Уральского), в том числе и Вологодская область. Низкий уровень результативности трудового поведения населения свидетельствует о депрессивности территорий и требует незамедлительного принятия комплекса мер, направленных на активизацию поиска резервов и повышение эффективности формирования и использования трудового потенциала.

Ключевые слова: трудовое поведение, интегральный индекс, регион, результативность трудового поведения. 
Popov A.V.

\section{Assessment of the effectiveness of population's labor behaviour at the macro-level}

Popov Andrey Vasilyevich - Junior Research Associate, Department of Living Standards and Lifestyle Studies, Federal State-Financed Scientific Institution the Institute of Socio-Economic Development of Territories of the Russian Academy of Sciences (56A, Gorky Street, Vologda, 160014, Russia, ai.popov@yahoo.com).

Abstract. The article considers the main approaches to the research into the effectiveness of people's labor behavior. Special attention is paid to the analysis of statistical, social and statistical-sociological methods. The article presents the author's methodology for analyzing the effectiveness of labor behavior by the spheres of manifestation: in the labor market and in an organization. The research shows a high degree of differentiation by this indicator among the Russian territories. The indicator's value was the highest in the Ural Federal District ( 0.588 points) and Central Federal District (0.422 points); it was the lowest in the Siberian ( -0.139 points) and North Caucasian ( -1.269 points) federal districts. The integrated assessment of the people's labor behavior effectiveness was conducted, 5 groups of RF regions were allocated according to this criterion depending on the indicator's value. The results of the analysis show that the territories with the high level of the indicator under consideration include such subjects of the Central Federal District as Moscow and the Moscow Oblast. The majority of RF subjects constitute the group with the level above medium. The medium-level group includes the regions that are part of nearly all the districts (except for the Ural Federal District), including the Vologda Oblast. The low level of labor behavior effectiveness indicates a depressive character of the territories and requires immediate measures for enhancing the search for reserves and increase in the efficiency of formation and use of labor potential.

Key words: labor behavior, integral index, region, effectiveness of labor behavior.

Конец XX - начало XXI века стало временем кардинальных перемен в российском обществе. Перевод предприятий в частную собственность, недостаточное внимание новых субъектов собственности к традиционным методам развития производственной активности рядовых работников привели к смене сложившихся трудовых ценностей. Значительно возросла роль материальных притязаний работников, что повлекло за собой изменение характера трудовой деятельности и, как следствие, качественное преобразование их трудового потенциала.
Решение задач, стоящих перед руководством страны ${ }^{1}$, направленных на повышение темпов и обеспечение устойчивости экономического роста, увеличение реальных доходов граждан, достижение технологического лидерства, невозможно без повышения качества трудовой деятельности населения. Социально-экономические преобразования должны осуществляться высококвалифицированными и мотивированными работниками.

1 В соответствии с указами Президента РФ В.В. Путина от 21.05.2012 г. состав правительства обновился на три четверти. 
Данное положение актуализирует проблему анализа результативности трудового поведения, изучение которого позволяет выявить резервы для интенсификации труда в целом.

Трудовое поведение - способ практической реализации населением трудового потенциала, связанный с созиданием материальных и духовных благ с целью удовлетворения определенных человеческих потребностей ${ }^{2}$.

Изучение трудового поведения, являющегося в настоящее время предметом исследования многих дисциплин, таких как социология труда, экономика труда, психология труда и т. Д., носит междисциплинарный характер. Многообразие структурных элементов трудового поведения стало причиной возникновения большого количества концептуальных и методологических подходов к его анализу [7]. Несмотря на это, исследование проблемы результативности трудового поведения не получило соответствующего развития. Как правило, анализ ограничивался рассмотрением какого-либо одного аспекта, например влияния материальных и нематериальных стимулов на производительность труда работника, вопросов мотивации, удовлетворённости трудом и т. д.

Существующие подходы к оценке результативности трудового поведения можно условно разделить на две группы: социологические и статистико-социологические, причем основным классифицирующим признаком является методика, используемая при сборе информации. Рассмотрим представленные методы более подробно.

2 Подробное описание теоретических основ трудового поведения приведено в научно-исследовательской работе «Управление человеческим капиталом и инновационное развитие территорий» : заключительный отчет о НИР / исполн. А.А. Шабунова, Г.В. Леонидова, К.А. Устинова, А.В. Попов, А.М. Панов. - Вологда, 2012. C. $34-42$.
В настоящее время наибольшее количество исследований трудового поведения населения основано на использовании социологических измерений. Среди них можно выделить как «стандартные» опросы и анкетирование, так и тесно связанные с ними психодиагностику и тестирование. Это обусловлено прежде всего психологической составляющей трудового поведения.

Одним из примеров социологического подхода, позволяющего наглядно произвести расчёт интегральной характеристики результативности трудового поведения, является методика, разработанная в Институте социально-экономического развития территорий РАН (ИСЭРТ РАН). Поскольку трудовое поведение представляет собой «способ практической реализации трудового потенциала населением», его результативность определяется на основе того, насколько полно трудоспособное население реализует свой потенциал [10, с. 106-108].

Чтобы оценить уровень использования населением своих качеств и умений в трудовой деятельности, в рамках мониторинга трудового потенциала ${ }^{3}$ была разработана специальная методика, основанная на блоке вопросов вида: «Насколько сильно Вы «выкладываетесь» на работе? В какой мере используете свои качества и умения?» В исследовании используется следующая четырехбалльная шкала: «использую в полной мере (на пределе своих возможностей)» - 4 балла; «более-менее полно (могу использовать больше)» - 3; «частично (мало)» -2 ; «очень мало (по минимуму)» -1 .

3 Мониторинг качества трудового потенциала населения Вологодской области проводится ИСЭРТ РАН с 1997 года. Объектом исследования является трудоспособное население Вологодской области. Опросы проходят ежегодно в августе - сентябре в городах Вологде и Череповце и в восьми районах области (Бабаевском, Великоустюгском, Вожегодском, Грязовецком, Кирилловском, Никольском, Тарногском и Шекснинском). Метод опроса - анкетирование по месту жительства респондентов. Объём выборки составляет 1500 человек, ошибка выборки не превышает $3 \%$. 
В дальнейшем путем деления фактического числа баллов на максимально возможное полученные баллы переводятся в индексы, условно названые индексами реализации трудового потенциала и соответствующие восьми базовым индексам качества трудового потенциала (рuc. 1).

Содержательный смысл полученных индексов заключается в следующем: каждый индекс показывает, какая доля имеющегося качества в действительности реализуется в трудовой деятельности, т.е. если индекс равен 0,25 ед., это означает, что человек реализует свой потенциал только на четверть. Умножая рассчитанные индексы на 100\%, получим показатель, отражающий то, на сколько процентов реализуется качество трудового потенциала, т.е. это своеобразный аналог уровня занятости, показывающего то, на сколько процентов реализуется количество трудового потенциала. Рассчитанный таким образом показатель был условно назван уровнем реализации качества трудового потенциала.
Результативность трудового поведения определяется как средний уровень реализации трудового потенциала [9, с. 45].

Основными достоинствами подхода являются: использование данных, которые невозможно получить в органах официальной статистики; возможность самостоятельного определения генеральной выборки и т. д., что значительно расширяет исследование.

В то же время высокая эффективность социологических методов, используемых в процессе изучения различных аспектов трудового поведения, нивелируется при оценке его результативности в связи с тем, что интегральный показатель образуется на основе субъективных оценок респондентов. Получение более объективных результатов исследования возможно за счёт совершенствования методологической базы и методики сбора информации.

Использование статистико-социологического метода позволяет избежать ряда слабых сторон социологического подхода за счёт интеграции последнего с данными

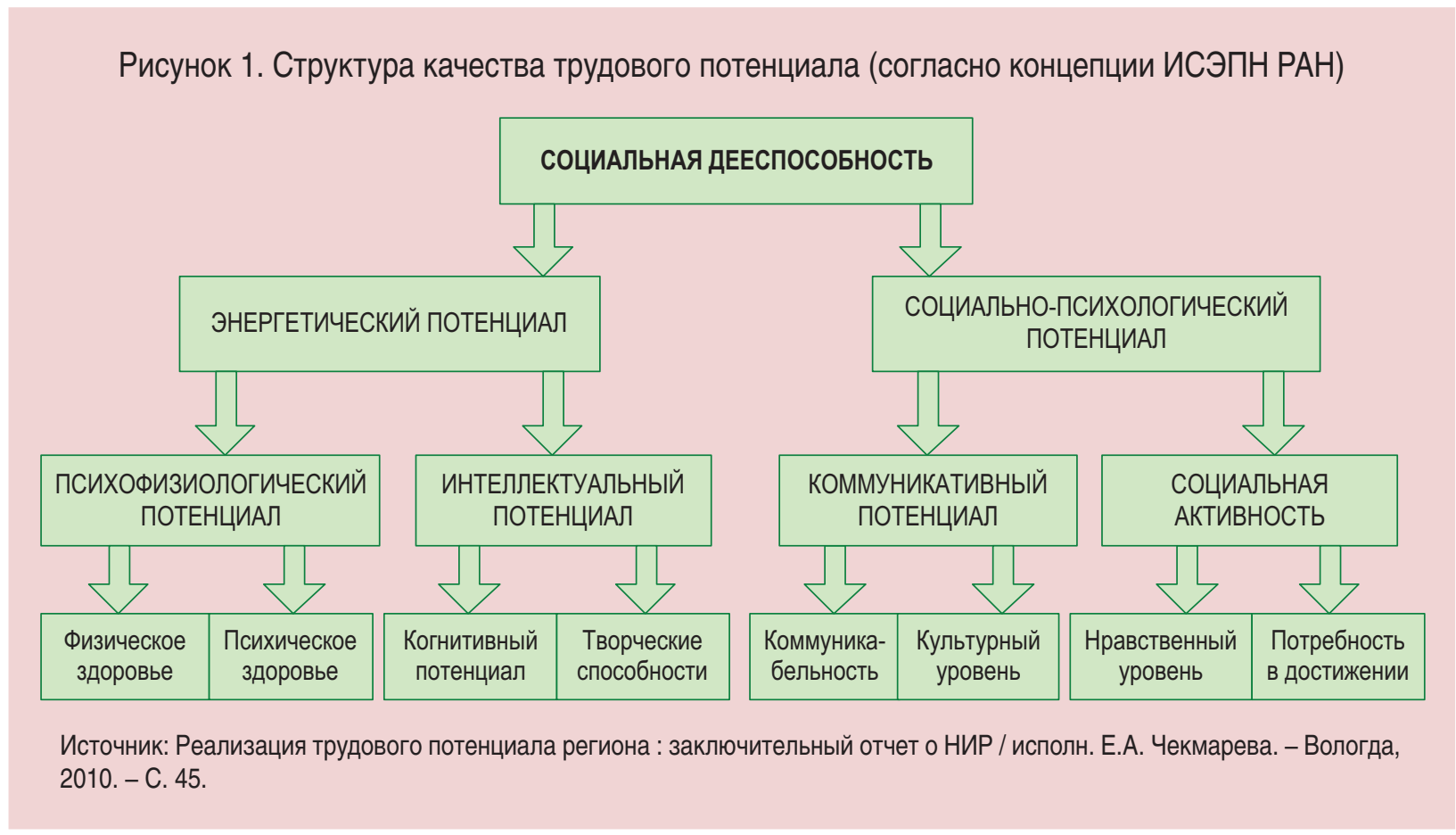


Таблица 1. Показатели результативности трудового поведения на рынке труда

\begin{tabular}{|c|c|}
\hline Показатель & $\begin{array}{c}\text { Единица } \\
\text { измерения }\end{array}$ \\
\hline \multicolumn{2}{|l|}{ Объективные } \\
\hline \multicolumn{2}{|l|}{ Прямые } \\
\hline Средняя продолжительность поиска работы & Mec. \\
\hline Среднее количество времени, затрачиваемое на поиск работы & Ч. в неделю \\
\hline Доля активных профильных групп в численности ищущих работу & $\%$ \\
\hline Среднее количество используемых способов поиска работы в расчете на одного ищущего работу & Ед. \\
\hline Среднее количество обращений к работодателям по вопросам трудоустройства & Ед. \\
\hline $\begin{array}{l}\text { Среднее количество отказов человека от работы, предлагаемой службой занятости (государственной } \\
\text { и коммерческой), родственниками, друзьями или работодателем }\end{array}$ & Ед. \\
\hline Коэфффициент самостоятельности населения в вопросах трудоустройства & - \\
\hline \multicolumn{2}{|l|}{ Косвенные } \\
\hline Охват населения услугами службы занятости по трудоустройству & $\%$ \\
\hline Доля прошедших обучение в численности ищущих работу & $\%$ \\
\hline Структура распределения численности ищущих работу по способам поиска работы & $\%$ \\
\hline \multicolumn{2}{|l|}{ Субъективные } \\
\hline \multicolumn{2}{|l|}{ Прямые } \\
\hline Удовлетворенность тем рабочим местом, на которое трудоустраивается человек & $\%$ \\
\hline Положительная оценка собственной деятельности по поиску работы & $\%$ \\
\hline \multicolumn{2}{|l|}{ Косвенные } \\
\hline Удовлетворенность лиц, ищущих работу, своим состоянием, существующим положением дел & $\%$ \\
\hline Уровень предприимчивости, деловая хватка ищущих работу & $\%$ \\
\hline Уровень оптимизма в вопросах трудоустройства & $\%$ \\
\hline
\end{tabular}

официальной статистики. Основные преимущества этого метода заключаются в получении более достоверных результатов анализа и возможности учёта множества факторов за счёт обширной информационной базы. Вместе с тем к недостаткам подхода можно отнести ограниченность использования результатов исследования, трудоёмкость и сложность формирования интегральных показателей.

Среди статистико-социологических методов оценки результативности трудового поведения наиболее крупным является разработка И.А. Кульковой [5]. Её исследование основывается на использовании ряда показателей, объективных (статистических) и субъективных (социологических). В качестве примера в таблице 1 представлена классификация индикато- ров, характеризующих трудовое поведение населения на рынке труда как одной из сфер его применения ${ }^{4}$.

В целом как существенный минус представленных подходов можно отметить ограниченность использования, поскольку получение социологических данных является высокозатратным мероприятием. В этой связи актуальной становится разработка методики оценки результативности трудового поведения на основе материалов официальной статистики.

Статистический метод, как правило, не подходит для анализа мотивации, установок, ценностей и т. д., но он отражает

4 Стоит отметить, что в зарубежной и отечественной литературе наибольшее развитие получило изучение трудового поведения людей в рамках организации/предприятия. 
конечный результат трудового поведения и поэтому может успешно применяться для расчёта показателей его результативности. Данный подход упрощает и унифицирует набор индикаторов, способствуя географическому расширению исследования за счёт доступности информационной базы.

Результативность трудового поведения мы исследуем на примере экономически активного населения России на основе материалов официальной статистики.

В основе этого исследования, как и у ряда учёных (И.А. Кулькова [3, 4], Н.И. Шаталова [9] и др.), лежит разделение трудового поведения по сферам его проявления (табл. 2):

1. Рынок труда. В расчёт индикатора трудового поведения работников на рынке труда включены: уровень безработицы; средняя продолжительность поиска работы безработными; удельный вес безработных, ищущих работу 12 месяцев и более; структура безработных по способам поиска места работы. В ходе экспертной оценки им был присвоен весовой коэффициент равный 1.

Поиск дополнительной занятости обладает меньшим весом в данном индикаторе, но как фактор проявления гиперактивного трудового поведения включён в перечень характеризующих его показателей. Его меньший весовой коэффициент обусловлен необязательным индикатором функционирования рынка труда.

2. Организация. Результативность трудового поведения людей на рабочих местах характеризуется такими показателями, как уровень занятости, производительность труда, количество часов, отработанных в неделю, в расчёте на одного занятого, удельный вес пострадавших при несчастных случаях и удельный вес работников, прошедших дополнительное профессиональное обучение.

Таблица 2. Показатели, характеризующие трудовое поведение

\begin{tabular}{|c|c|c|c|}
\hline $\begin{array}{l}\text { № } \\
\text { п/п }\end{array}$ & Показатель & $\begin{array}{c}\text { Единица } \\
\text { измерения }\end{array}$ & $\begin{array}{l}\text { Весовой } \\
\text { коэфр-т }\end{array}$ \\
\hline \multicolumn{4}{|c|}{ Трудовое поведение на рынке труда } \\
\hline 1. & Уровень безработицы (по МОТ) & $\%$ & 1,0 \\
\hline 2. & Средняя продолжительность поиска работы безработными & Mec. & 1,0 \\
\hline 3. & Удельный вес безработных, ищущих работу 12 месяцев и более & $\%$ & 1,0 \\
\hline 4. & Структура безработных по способам поиска работы & $\%$ & 1,0 \\
\hline 5. & Ищут дополнительную занятость & $\begin{array}{l}\% \text { от занятого } \\
\text { населения }\end{array}$ & 0,5 \\
\hline \multicolumn{4}{|c|}{ Трудовое поведение в организации } \\
\hline 1. & Уровень занятости & $\%$ & 1,0 \\
\hline 2. & Производительность труда & $\begin{array}{c}\text { Тыс. руб. на } \\
\text { одного занятого }\end{array}$ & 1,0 \\
\hline 3. & Отработано в неделю в среднем на одного занятого & 4. & 1,0 \\
\hline 4. & $\begin{array}{l}\text { Удельный вес пострадавших при несчастных случаях на производстве с утратой } \\
\text { трудоспособности на один рабочий день и более и со смертельным исходом }\end{array}$ & $\begin{array}{l}\text { В \% на } 1000 \\
\text { работающих }\end{array}$ & 1,0 \\
\hline 5. & $\begin{array}{l}\text { Удельный вес работников, прошедших дополнительное профессиональное } \\
\text { обучение }\end{array}$ & $\begin{array}{c}\text { Обучено в \% } \\
\text { от общей } \\
\text { численности } \\
\text { работников }\end{array}$ & 1,0 \\
\hline 6. & $\begin{array}{l}\text { Фактическое количество часов, отработанных на дополнительной работе, в } \\
\text { среднем на одного занятого в год }\end{array}$ & 4. & 0,5 \\
\hline 7. & Удельный вес занятого населения, выезжающего на работу в другие субъекты РФ & $\begin{array}{l}\text { \% от занятого } \\
\text { населения }\end{array}$ & 0,5 \\
\hline
\end{tabular}


Выбор данных индикаторов обусловлен тем, что трудовое поведение проявляется посредством трудовой активности, которая в свою очередь охватывает:

- трудовую деятельность;

- характер трудовой активности;

- дисциплинированность участников трудового процесса [6, с. 39].

К дополнительным параметрам относятся индикаторы, позволяющие оценить масштабы дополнительной занятости и трудовой мобильности населения.

Для приведения разнородных показателей в сопоставимый вид с учетом их направленности (прямая/обратная) нами была применена стандартизация путём Z-преобразования.

Отрицательные значения индекса свидетельствуют о его расположении ниже среднего из всей выборки, положительныео расположении выше:

$$
x_{i}=\frac{a_{i}-\bar{a}}{\sigma},
$$

где $a_{i}-$ значение переменной;

$\bar{a}$ - среднее значение переменной;

$\sigma$ - среднеквадратическое отклонение.

$$
\sigma=\sqrt{\frac{\sum_{\mathrm{i}=1}^{\mathrm{n}}\left(\mathrm{a}_{\mathrm{i}}-\overline{\mathrm{a}}\right)^{2}}{\mathrm{n}} .}
$$

Данный метод индексации был выбран в связи с тем, что некоторые переменных имеют различный размах значений или их значения отличаются на порядки друг от друга, поэтому использование максимальных и минимальных величин в данной методике нецелесообразно.

Сводный индекс каждого из блоков представляет собой сумму всех наблюдаемых значений, деленных на их количество (среднее арифметическое). Интегральный индекс результативности трудового пове- дения определяется аналогичным образом и рассчитывается по следующей формуле:

$$
P L B_{i}=\frac{L B M_{i}+L B O_{i}}{2},
$$

где $P L B_{i}$ (Productivity of labor behavior) интегральный индекс результативности трудового поведения населения;

$L B M_{i}$ (Productivity of labor behavior on labor market) - сводный индекс результативности трудового поведения населения на рынке труда;

$L B O_{i}$ (Productivity of labor behavior in organization) - сводный индекс результативности трудового поведения населения в организации.

Поскольку индексы рассчитываются отдельно как для округов, так и для регионов Российской Федерации, их значения будут варьироваться в зависимости от того, какая территория лежит в основе исследования.

Результативность трудового поведения населения на рынке труда

В 2010 г. наибольшее значение индекса результативности трудового поведения на рынке труда можно было наблюдать в Уральском федеральном округе $(0,625$ ед.; табл. 3). Несмотря на достаточно высокий уровень безработицы на этой территории $(8,0 \%)$, остальные показатели значительно ниже среднероссийских. Наименьшее значение индекса отмечается в СевероКавказском округе, а абсолютным аутсайдером является Чеченская Республика (-2,622 ед.).

Северо-Западный федеральный округ занимает пятую позицию среди округов. Дифференциация значений индекса в СЗФО колеблется от 0,050 ед. в Калининградской области до 0,567 ед. в Архангельской. Вологодская область в рейтинге регионов Северо-Запада занимает седьмую позицию (0,137 ед.). 
Таблица 3. Сводные индексы результативности трудового поведения населения (2010 г.)

\begin{tabular}{|l|l|l|}
\hline \multicolumn{1}{|c|}{ Территория } & \multicolumn{1}{c|}{ LBM, ед. } & LBO, ед. \\
\hline Уральский федеральный округ & $\mathbf{0 , 6 2 5}$ & $\mathbf{0 , 5 5 1}$ \\
\hline Центральный федеральный округ & $\mathbf{0 , 4 1 0}$ & $\mathbf{0 , 4 3 4}$ \\
\hline Приволжский федеральный округ & $\mathbf{0 , 3 2 4}$ & $\mathbf{0 , 1 3 3}$ \\
\hline Южный федеральный округ & $\mathbf{0 , 2 9 1}$ & $\mathbf{- 0 , 0 0 2}$ \\
\hline Северо-Западный федеральный округ & $\mathbf{0 , 2 3 2}$ & $\mathbf{0 , 0 3 1}$ \\
\hline г. Санкт-Петербург & 0,419 & 0,442 \\
\hline Ленинградская область & 0,118 & 0,340 \\
\hline Республика Коми & 0,425 & 0,001 \\
\hline Мурманская область & \\
\hline Новгородская область & 0,416 & 0,146 \\
\hline Архангельская область & 0,119 & $-0,075$ \\
\hline Псковская область & 0,567 & \\
\hline Калининградская область & 0,317 & $-0,305$ \\
\hline Вологодская область & 0,050 & $-0,075$ \\
\hline Республика Карелия & 0,137 & $-0,017$ \\
\hline Дальневосточный федеральный округ & 0,210 & $-0,209$ \\
\hline Сибирский федеральный округ & & $-0,539$ \\
\hline Северо-Кавказский федеральный округ & & $-\mathbf{0 , 1 1 4}$ \\
\hline Источник: составлено автором. & & $-\mathbf{0 , 2 7 7}$ \\
\hline
\end{tabular}

В целом можно отметить, что большинство федеральных округов, за исключением Северо-Кавказского и Дальневосточного, относятся к территориям со средним и высоким уровнем результативности трудового поведения населения на рынке труда. В число лидеров по данному показателю входят Уральский и Центральный округа, а г. Москва является абсолютным лидером среди субъектов РФ по большинству параметров.

Результативность трудового поведения населения в организации

В 2010 г. максимальное и минимальное значения индекса результативности трудового поведения населения в организации продемонстрировали Уральский (0,551 ед.) и Северо-Кавказский (-0,755 ед.) федеральные округа. В первом случае это обусловлено высоким уровнем занятости, созданием работниками больших объёмов продукции в единицу времени, участием в получении дополнительного образования.
Во втором - общей трудовой пассивностью населения, обусловленной не только личностными факторами, но и условиями внешней среды.

Северо-Западный федеральный округ по данному показателю занимает четвёртую позицию. Интегральная характеристика составляет здесь 0,031 ед., что незначительно выше среднероссийского уровня. Абсолютное лидерство в СЗФО принадлежит г. Санкт-Петербургу (0,442 ед.) и Ленинградской области (0,340 ед.).

Вологодская область по результативности трудового поведения на рабочих местах относится к аутсайдерам округа и России в целом, демонстрируя значение индекса -0,209 ед. Негативное влияние на данный показатель оказали такие факторы, как низкий уровень производительности труда (489,2 тыс. руб.) и трудовой мобильности (0,6\% занятого населения), высокая доля пострадавших на производстве $(4,4 \%$ на 1000 работающих). 
Заключительным этапом методики является расчёт интегральной характеристики результативности трудового поведения населения субъектов Российской Федерации на основе приведённых сводных индексов.

Интегральный индекс результативности трудового поведения населения

Лидирующие позиции в рейтинге федеральных округов занимают Уральский и Центральный: индекс результативности трудового поведения на данных территориях составляет соответственно 0,588 и 0,422 ед. (табл. 4).

Дифференциацию результативности трудового поведения в Уральском федеральном округе можно охарактеризовать как высокую: максимальное значение индекса наблюдается в Тюменской (0,490 ед.), минимальное - в Курганской $(-0,274$ ед.) областях.

В Центральном федеральном округе наиболее высокую оценку результативности трудового поведения населения демонстрирует г. Москва (1,315 ед.), наиболее низкую - Тамбовская область (-0,333 ед.). В целом результаты анализа свидетельствуют о существовании большого разрыва между Московской областью и остальными субъектами округа. Ближайшей по иерархии территорией в округе является Тверская область, где значение интегрального показателя составляет 0,247 ед.

Интегральный показатель результативности трудового поведения в Приволжском федеральном округе равняется 0,229 ед. На территории отмечена умеренная дифференциация трудового поведения: значение индекса колеблется от 0,498 ед. (Самарская обл.) до -0,164 ед. (Ульяновская обл.).

Южный и Северо-Западный федеральные округа замыкают список субъектов с индексом выше среднероссийского уровня - 0,144 и 0,131 ед. соответственно. Лидерами по данному показателю в рассматриваемых округах являются Краснодарский край
$(0,316$ ед.) и г. Санкт-Петербург (0,430 ед.), а аутсайдерами - республики Калмыкия $(-0,777$ ед.) и Карелия $(-0,165$ ед.).

Индекс результативности трудового поведения в Вологодской области составил -0,036 ед., что незначительно ниже среднероссийского уровня. Среди основных факторов, оказывающих негативное влияние на интегральную характеристику, можно отметить:

- низкую активность населения в процессе трудоустройства;

- низкий уровень производительности труда;

- высокий травматизм на производстве;

- низкую трудовую мобильность.

Самый низкий уровень результативности трудового поведения населения наблюдается в Северо-Кавказском федеральном округе - только в одном из семи входящих в него субъектов (Ставропольский край) отмечен среднероссийский уровень $(0,022$ ед.). Остальные территории относятся к группе с низким уровнем, причем Кабардино-Балкарская, Карачаево-Черкесская и Чеченская республики входят в группу субъектов, имеющих критически низкий уровень результативности трудового поведения, и занимают последние места в рейтинге регионов РФ.

Анализ интегральной характеристики результативности трудового поведения населения регионов нашей страны позволил разделить все территории на несколько условных групп:

- низкий уровень - от $-1,830$ ед. до $-1,201$ ед.;

- ниже среднего уровня - от -1,200 ед. до $-0,571$ ед.;

- средний уровень - от -0,570 ед. до 0,059 ед.;

- выше среднего уровня - от 0,060 ед. до 0,689 ед.;

- высокий уровень - от 0,690 ед. до 1,319 ед. (рис. 2). 
Таблица 4. Интегральный индекс результативности трудового поведения населения РФ (2010 г.)

\begin{tabular}{|c|c|c|c|c|}
\hline Территория & & PLB, ед. & Территория & PLB, ед. \\
\hline Уральский Ф0 & & 0,588 & Республика Адыгея & $-0,094$ \\
\hline Тюменская область & 0,490 & & Республика Калмыкия & $-0,777$ \\
\hline Челябинская область & 0,399 & & Северо-Западный Ф0 & 0,131 \\
\hline Свердловская область & 0,293 & & г. Санкт-Петербург & 0,430 \\
\hline Курганская область & & $-0,274$ & Ленинградская область & 0,229 \\
\hline Центральный Ф0 & & 0,422 & Республика Коми & 0,213 \\
\hline г. Москва & 1,315 & & Мурманская область & 0,171 \\
\hline Московская область & 0,698 & & Новгородская область & 0,133 \\
\hline Тульская область & 0,247 & & Архангельская область & 0,131 \\
\hline Ярославская область & 0,232 & & Псковская область & 0,121 \\
\hline Калужская область & 0,218 & & Калининградская область & 0,017 \\
\hline Смоленская область & 0,171 & & Вологодская область & $-0,036$ \\
\hline Ивановская область & 0,151 & & Республика Карелия & $-0,165$ \\
\hline Белгородская область & 0,143 & & Дальневосточный Ф0 & $-0,106$ \\
\hline Костромская область & 0,124 & & Чукотский автономный округ & 0,400 \\
\hline Владимирская область & 0,041 & & Сахалинская область & 0,362 \\
\hline Курская область & 0,029 & & Приморский край & 0,145 \\
\hline Рязанская область & & $-0,022$ & Камчатский край & 0,139 \\
\hline Тверская область & & $-0,092$ & Республика Саха (Якутия) & 0,052 \\
\hline Орловская область & & $-0,129$ & Магаданская область & $-0,137$ \\
\hline Брянская область & & $-0,205$ & Еврейская автономная область & $-0,149$ \\
\hline Липецкая область & & $-0,217$ & Хабаровский край & $-0,166$ \\
\hline Воронежская область & & $-0,254$ & Амурская область & $-0,173$ \\
\hline Тамбовская область & & $-0,333$ & Сибирский Ф0 & $-0,139$ \\
\hline Приволжский ФО & & 0,229 & Красноярский край & 0,462 \\
\hline Самарская область & 0,498 & & Томская область & 0,387 \\
\hline Нижегородская область & 0,421 & & Иркутская область & 0,203 \\
\hline Республика Татарстан & 0,387 & & Омская область & 0,188 \\
\hline Удмуртская Республика & 0,353 & & Республика Хакасия & 0,130 \\
\hline Чувашская Республика & 0,303 & & Новосибирская область & 0,045 \\
\hline Пермский край & 0,282 & & Кемеровская область & $-0,040$ \\
\hline Саратовская область & 0,227 & & Республика Бурятия & $-0,323$ \\
\hline Республика Башкортостан & 0,214 & & Забайкальский край & $-0,398$ \\
\hline Оренбургская область & 0,082 & & Алтайский край & $-0,505$ \\
\hline Пензенская область & 0,030 & & Республика Алтай & $-0,657$ \\
\hline Кировская область & & $-0,044$ & Республика Тыва & $-0,740$ \\
\hline Республика Мордовия & & $-0,085$ & Северо-Кавказский Ф0 & $-1,269$ \\
\hline Республика Марий Эл & & $-0,130$ & Ставропольский край & 0,022 \\
\hline Ульяновская область & & $-0,164$ & Республика Северная Осетия-Алания & $-0,400$ \\
\hline Южный ФО & & 0,144 & Республика Дагестан & $-0,551$ \\
\hline Краснодарский край & 0,316 & & Кабардино-Балкарская Республика & $-0,719$ \\
\hline Ростовская область & 0,205 & & Карачаево-Черкесская Республика & $-1,201$ \\
\hline Астраханская область & 0,138 & & Республика Ингушетия & $-1,234$ \\
\hline Волгоградская область & 0,042 & & Чеченская Республика & $-1,830$ \\
\hline
\end{tabular}


По результатам анализа было определено, что к территориям с высоким уровнем результативности трудового поведения относятся субъекты Центрального федерального округа г. Москва и Московская область.

Уровень результативности трудового поведения выше среднего характерен для следующих округов (в скобках указан процент от общего количества субъектов в округе):

1. Уральский -3 территории (75\%);

2. Северо-Западный -7 территорий $(70 \%)$

3. Приволжский -9 территорий $(64 \%)$;

4. Южный -3 территории (50\%);

5. Дальневосточный -4 территории (44\%);

6. Сибирский -5 территорий (42\%);

7. Центральный -7 территорий $(39 \%)$.
К группе со средним уровнем относятся субъекты всех округов, за исключением Уральского, в том числе и Вологодская область.

Ниже среднего уровень результативности трудового поведения характерен для таких округов, как:

1. Дальневосточный -4 территории $(44 \%)$;

2. Северо-Кавказский -3 территории $(43 \%)$;

3. Сибирский -5 территорий (42\%);

4. Центральный -6 территорий $(33 \%)$;

5. Южный -2 территории (33\%);

6. Уральский -1 территория (25\%);

7. Приволжский -3 территории (21\%);

8. Северо-Западный -1 территория $(10 \%)$.

Нижние позиции в рейтинге занимают регионы Северо-Кавказского федерального округа (республики Карачаево-Черкесская, Ингушетия и Чеченская).

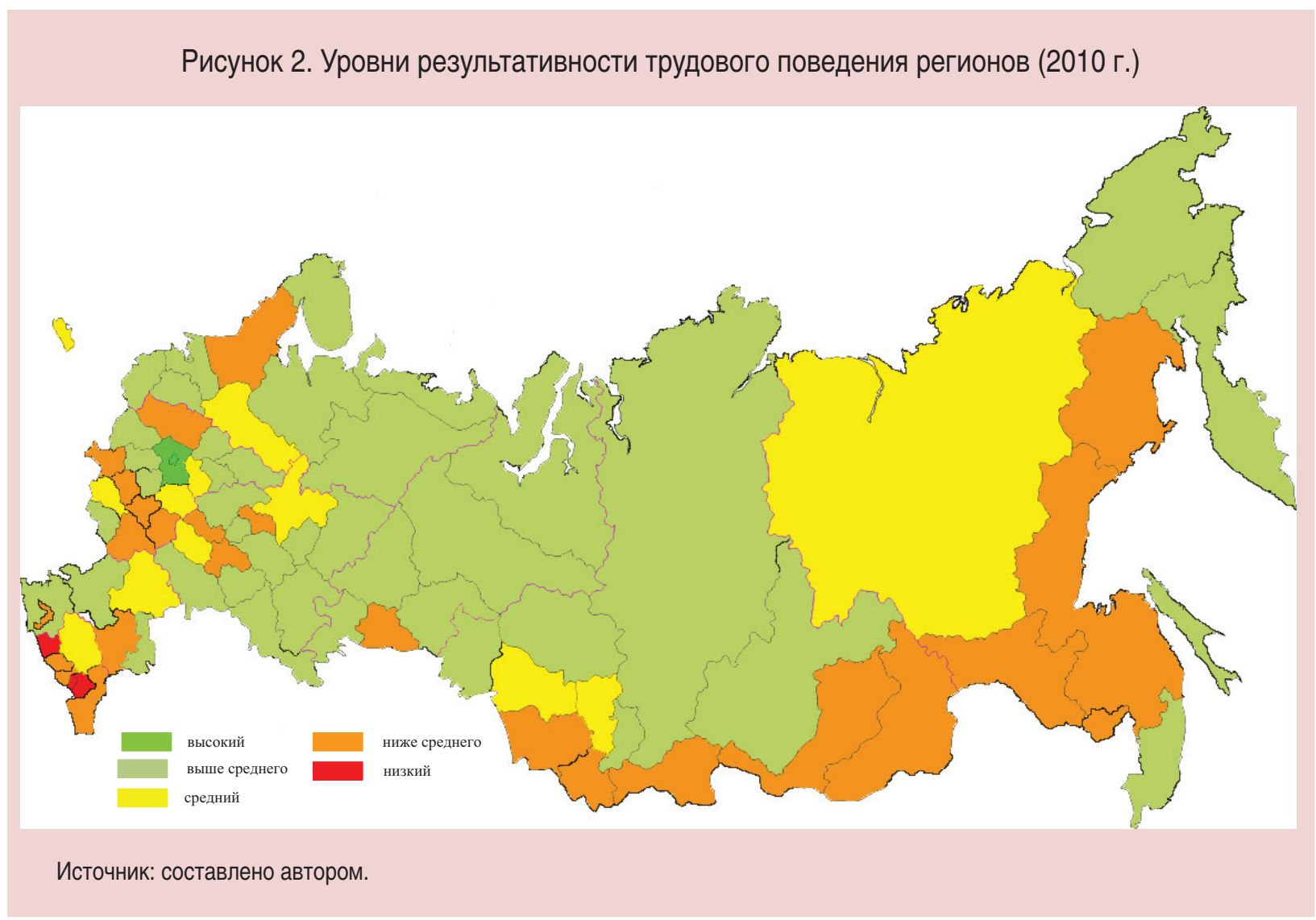


Таким образом, на основе проведенного анализа установлено, что уровень результативности трудового поведения населения большинства регионов России характеризуется как средний и выше среднего. Значительная часть регионов с низким уровнем являются депрессивными, поэтому требуется незамедлительно принимать комплекс мер, направленных на активизацию поиска резервов и повышение эффективности формирования и использования трудового потенциала.

В целом оценка результативности трудового поведения населения позволила выявить большой разрыв между субъектами РФ (в том числе внутри одного федерального округа) по данному показателю, что свидетельствует о необходимости корректировки государственной политики в области занятости населения. В первую очередь это касается разработки региональных программ, в основе которых должна лежать дифференцированная система мероприятий по повышению эффективности функционирования рынка труда с учётом тенденций трудового поведения населения конкретной территории.

\section{Литература}

1. Верховин, В.И. Содержание, структура и функции трудового поведения [Текст] / В.И. Верховин // Социологические исследования. - 1991. - №11. - С. 25-36.

2. Гулин, К.А. Трудовой потенциал региона [Текст] / К.А. Гулин, А.А. Шабунова, Е.А. Чекмарева. Вологда : ИСЭРТ РАН, 2009. - 84 c.

3. Кулькова, И.А. Оценка активности трудового поведения человека в период поиска работы [Электронный ресурс] / И.А. Кулькова. - Режим доступа : http://www.e-rej.ru/Articles/2007/Kulkova.pdf

4. Кулькова, И.А. Поиск работы как составляющая трудового поведения [Текст] / И.А. Кулькова // Вопросы экономики. - 2008. - №6. - С. 111-117.

5. Кулькова, И.А. Управление трудовым поведением как фактор усиления трудовой мотивации [Текст] : автореф. дис. на соиск. ученой степ. Д-ра экон. наук : 08.00.05 / И.А. Кулькова. - Ижевск, 2009. -45 с.

6. Проблемы эффективности государственного управления. Человеческий капитал территорий: проблемы формирования и использования [Текст] : монография / Г.В. Леонидова, К.А. Устинова, А.В. Попов, А.М. Панов, М.А. Головчин, Т.С. Соловьева, Е.А. Чекмарева ; под ред. А.А. Шабуновой. - Вологда : ИСЭРТ РАН, 2013. - $184 \mathrm{c}$.

7. Темницкий, А.Л. Теоретико-методологические подходы к исследованию трудового поведения [Текст] / А.Л. Темницкий // Социологические исследования. - 2007. - №6. - С. 60-71.

8. Тихомирова, Т.М. Оценка вектора развития человеческого потенциала в субъектах РФ [Текст] / Т.М. Тихомирова, А.Г. Сукиасян // Вестник Российского экономического университета имени Г.В. Плеханова. - 2013. - №2(56). - С. 81-91.

9. Чекмарева, Е.А. Реализация трудового потенциала региона [Текст] : заключительный отчет о НИР / исполн. Е.А. Чекмарева. - Вологда, 2010. - 94 с.

10. Шаталова, Н.И. Трудовой потенциал работника [Текст] : учеб. пособие для вузов / Н.И. Шаталова. М. : ЮНИТИ-ДАНА, 2003. - 399 с.

11. Champoux, Joseph E. Organizational Behavior: integrating individuals, groups, and organizations [Электронный ресурс] / Joseph Champoux. - Режим доступа : http://www.tandfebooks.com/action/showBook? doi $=10.4324 / 9780203872918$

\section{References}

1. Verkhovin V.I. Soderzhanie, struktura i funktsii trudovogo povedeniya [Content, Structure and Functions of Labor Behavior]. Sotsiologicheskie issledovaniya [Sociological Studies], 1991, no.11, pp. 25-36.

2. Gulin K.A., Shabunova A.A., Chekmareva E.A. Trudovoy potentsial regiona [Labour Potential of the Region]. Vologda: ISERT RAN, 2009. 84 p. 
3. Kul'kova I.A. Otsenka aktivnosti trudovogo povedeniya cheloveka v period poiska raboty [Evaluation of the Activity of Employment Behaviour in the Period of Job Search]. Available at: http://www.e-rej.ru/Articles/2007/ Kulkova.pdf

4. Kul'kova I.A. Poisk raboty kak sostavlyayushchaya trudovogo povedeniya [Looking for a Job as a Constituent of Labor Behavior]. Voprosy ekonomiki [Issues of Economics], 2008, no.6, pp. 111-117.

5. Kul'kova I.A. Upravlenie trudovym povedeniem kak faktor usileniya trudovoy motiva-tsii: avtoref. dis. na soisk. uchenoy step. d-ra ekon. nauk [Management of Labor Behavior as a Factor in Enhancing Labor Motivation: Doctor of Economics Dissertation Abstract]. Izhevsk, 2009. 45 p.

6. Leonidova G.V., Ustinova K.A., Popov A.V., Panov A.M., Golovchin M.A., Solovyeva T.S., Chekmareva E.A. Problemy effektivnosti gosudarstvennogo upravleniya. Chelovecheskiy kapital territoriy: problemy formirovaniya $i$ ispol'zovaniya: monografiya [Problems of State Management Effectiveness. Human Capital of the Territories: Problems of Formation and Use: Monograph]. Ed. by A.A. Shabunova. Vologda: ISERT RAN, 2013. 184 p.

7. Temnitskiy A.L. Teoretiko-metodologicheskie podkhody k issledovaniyu trudovogo povedeniya [Theoretical and Methodological Approaches to the Study of Labor Behavior]. Sotsiologicheskie issledovaniya [Sociological Studies], 2007, no.6, pp. 60-71.

8. Tikhomirova T. M., Sukiasyan A. G. Otsenka vektora razvitiya chelovecheskogo potentsiala v sub»ektakh RF [The Estimation of the Vector of Human Potential Development in the Russian Federation Subjects]. Vestnik Rossiyskogo ekonomicheskogo universiteta imeni G. V. Plekhanova [Bulletin of Plekhanov Russian University of Economics], 2013, no.2(56), pp. 81-91.

9. Chekmareva E.A. Realizatsiya trudovogo potentsiala regiona: zaklyuchitel'nyy otchet o NIR [Implementation of the Region's Labor Potential]. Executed by E.A. Chekmareva. Vologda, 2010. 94 p.

10. Shatalova N.I. Trudovoy potentsial rabotnika: ucheb. posobie dlya vuzov [Labour Potential of an Employee: Textbook for Higher Schools]. Moscow: YuNITI-DANA, 2003. 399 p.

11. Champoux J. E. Organizational Behavior: Integrating Individuals, Groups, and Organizations. Available at: http:// www.tandfebooks.com/action/showBook?doi=10.4324/9780203872918 


\section{АКАДЕМИКУ РАН ЧЛЕНУ РЕДАКЦИОННОГО СОВЕТА ЖУРНАЛА ОКРЕПИЛОВУ ВЛАДИМИРУ ВАЛЕНТИНОВИЧУ - 70 ЛЕТ}

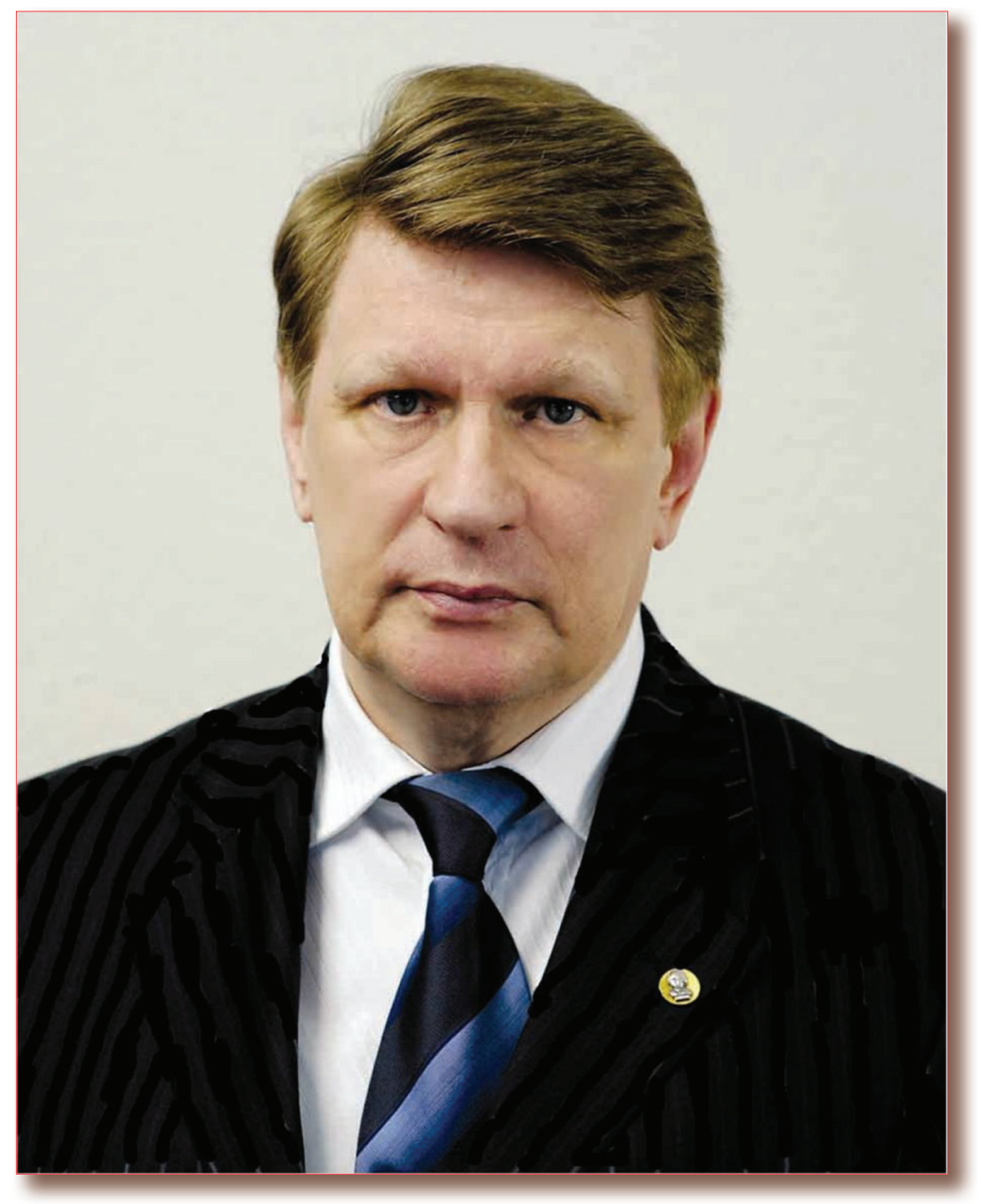

Исполнилось 70 лет со дня рождения видного ученого-экономиста академика Российской академии наук генерального директора Федерального бюджетного учреждения «Государственный региональный центр стандартизации, метрологии и испытаний в г. Санкт-Петербурге и Ленинградской области» Владимира Валентиновича Окрепилова. 
В.В. Окрепилов родился 23 февраля 1944 г. в городе Ленинграде. В 1970 г. окончил Ленинградский механический институт по специальности «механическое оборудование автоматических установок». Свою трудовую деятельность начал с 1965 года на Ленинградском заводе радиотехнического оборудования, где прошел путь от слесаря и техника до инженера-технолога и старшего инженера-конструктора.

В 80-е годы Владимир Валентинович работал главным инженером научно-производственного объединения «ВНИИМ имени Д.И. Менделеева», а затем директором Ленинградского центра стандартизации и метрологии Госстандарта СССР.

Вот уже более четверти века он руководит учреждением «Тест-С.-Петербург», созданным по инициативе Д.И. Менделеева в 1900 году как первая СанктПетербургская поверочная палатка торговых мер и весов с целью обеспечения единства и достоверности измерений на всей территории России.

В научных кругах В.В. Окрепилов известен как основатель новой области экономической науки - экономики качества, базирующейся на применении инструментов менеджмента качества, стандартизации и метрологии для обеспечения социальноэкономического прогресса и повышения качества жизни. Под его руководством впервые проведены фундаментальные научные исследования и практические расчеты экономического эффекта от деятельности в сфере стандартизации и метрологии; разработана не имеющая прямых аналогов в мире национальная система управления качеством, основанная на реализации методов программно-целевого планирования и направленная на повышение темпов модернизации экономики страны.

Владимир Валентинович внес решающий научно-организационный вклад в создание уникальной, научно обоснован- ной многоуровневой системы непрерывного обучения кадров - экономики качества. Возглавляемая им научная школа «Экономика и управление качеством» входит в Реестр ведущих научных и научно-педагогических школ Санкт-Петербурга.

Академик В.В. Окрепилов - автор более 450 научных работ, выполненных в области экономики качества, повышения эффективности инновационного развития, теории стандартизации и обеспечения единства измерений.

Он является учредителем электронного журнала «Экономика качества», главным редактором журнала «Экономика СевероЗапада: проблемы и перспективы развития», членом редколлегий множества журналов.

Вся его профессиональная, научная и общественная деятельность направлена на решение социально-экономических проблем Санкт-Петербурга и Северо-Западного региона в целом, развитие их научнопроизводственного потенциала, повышение качества жизни граждан.

Владимир Валентинович является одним из разработчиков «Концепции повышения качества и конкурентоспособности продукции промышленных предприятий Санкт-Петербурга»; стандартов проживания, утвержденных Законом СанктПетербурга от 15 ноября 2005 г. №584-8; Стратегии социально-экономического развития Санкт-Петербурга до 2030 г; Комплексной научно-технической программы Северо-Западного федерального округа РФ до 2030 г.

Под его руководством проводится большая работа по подготовке научных кадров для исследования проблем качества.

Он заведует базовыми кафедрами в Санкт-Петербургском государственном экономическом университете и СанктПетербургском государственном университете аэрокосмического приборостроения; 


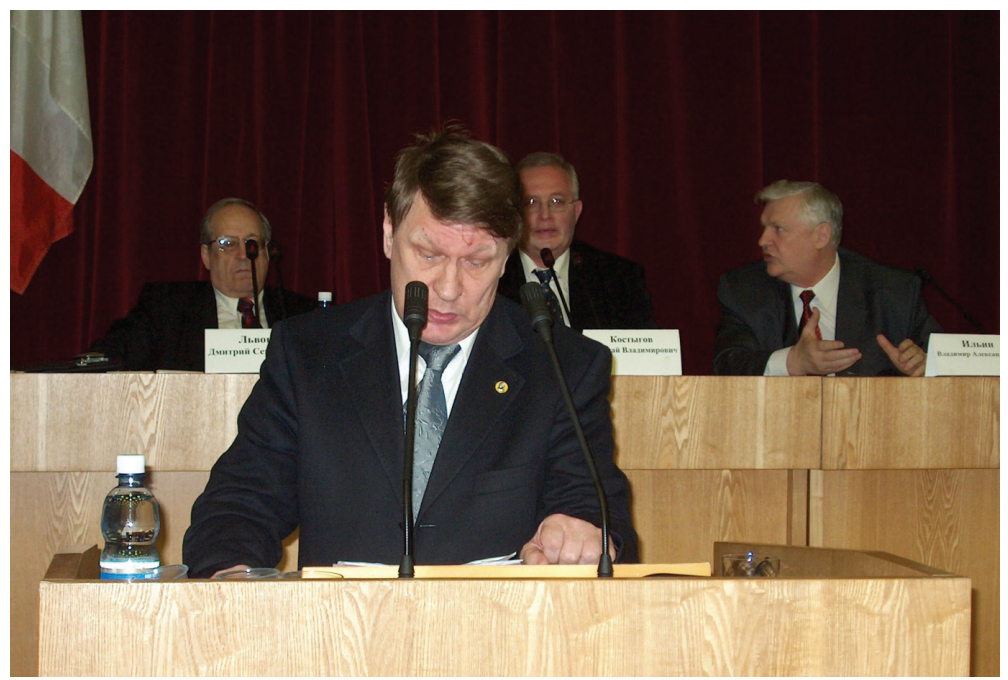

Выступление В.В. Окрепилова на Российской конференции «Стратегия и тактика реализации социально-экономических ресрорм: региональный аспект»

избран Почетным доктором в пяти ведущих университетах города; входит в состав Экспертного совета ВАК РФ.

В.В. Окрепилов ведет активную общественную деятельность, являясь сопредседателем Экономического совета при Губернаторе Санкт-Петербурга, заместителем председателя Научно-технического совета при Правительстве СанктПетербурга, членом Общественного совета Санкт-Петербурга, членом Президиума Союза промышленников и предпринимателей Санкт-Петербурга.

Его высокие достижения не раз отмечались государственными премиями и наградами в области науки, техники и образования. В.В. Окрепилов - заслуженный деятель науки и техники РФ, почетный работник науки и техники РФ. Награжден орденами «За заслуги перед Отечеством» IV степени, «Почета», «Дружбы народов», медалями, знаком отличия «За заслуги перед Санкт-Петербургом», нагрудными знаками «За заслуги в стандартизации» и «Почетный метролог», почетными дипломами Законодательного Собрания СанктПетербурга и Ленинградской области, грамотами Губернатора Санкт-Петербурга и Губернатора Ленинградской области.
Весом вклад В.В. Окрепилова в становление и развитие Института социальноэкономического развития территорий РАН. Владимир Валентинович неоднократно бывал в Вологде, выступая с докладами на организованных ИСЭРТ РАН международных научно-практических конференциях «Стратегия и тактика реализации социально-экономических реформ: региональный аспект», проходивших под председательством академика Д.С. Львова. Сегодня В.В. Окрепилов является членом редакционного совета журнала «Экономические и социальные перемены: факты, тенденции, прогноз», где опубликовал ряд статей.

Рекомендации Владимира Валентиновича приносят большую пользу в деле усиления практической и научной значимости проводимых Институтом исследований, повышения качества и актуальности журнала.

Коллектив ИСЭРТ РАН и редколлегия журнала горячо и сердечно поздравляют Владимира Валентиновича с замечательным юбилеем, благодарят его за плодотворное сотрудничество, выражая надежду на дальнейшее продолжение совместной работы, желают ему новых творческих успехов и благополучия! 


\section{ТРЕБОВАНИЯ К ОФОРМЛЕНИЮ СТАТЕЙ}

Предлагаемые статьи должны содержать результаты исследований, обладающие новизной и практической направленностью, являться доступными по форме изложения для широкого круга читателей, соответствовать научной направленности журнала (экономические и социологические науки).

Статья должна, как правило, содержать следующие аспекты: цель работы; метод и методологию проведения работы; её результаты; область применения результатов; выводы. Выводы могут сопровождаться рекомендациями, предложениями, гипотезами, вытекающими из содержания статьи. При представлении в статье результатов социологических исследований необходимо указать следующую информацию: сведения о методологии и методике; дату, место (территорию) и организацию, проводившую исследование; структуру генеральной совокупности; тип, объем и ошибку выборки; описание методов сбора и анализа данных. Данную информацию следует изложить в одном из следующих вариантов: в специальном разделе (параграфе) статьи; непосредственно в тексте; в сноске. При оформлении таблиц важно пояснить, как считаются проценты: от числа ответивших на данный вопрос или от совокупности опрошенных. Пристатейный список литературы должен быть представительным, демонстрировать профессиональный кругозор и качественный уровень исследований авторов. Работы в пристатейном списке располагаются в алфавитном порядке сначала на русском, затем на английском (или любом другом - на латинице) языке. При ссылке в тексте даётся номер работы в квадратных скобках.

Авторы несут ответственность за подбор и достоверность приведённых фактов, цитат, статистических и социологических данных, имён собственных, географических названий и прочих сведений, а также за то, чтобы в статье не содержалось данных, не подлежащих открытой публикации.

Приводимые в таблицах (графиках) стоимостные показатели, относящиеся к разным временным периодам, представляются, как правило, в сопоставимой оценке. Если в таблицах (графиках) содержатся сравнительные данные по отдельным территориям, видам экономической деятельности и т.П., то они представляются в ранговом порядке с указанием периода, по которому производится ранжирование.

Объём статьи - не более 40000 знаков (1 а.л.), включая пробелы и сноски, для докторов и кандидатов наук (в том числе при соавторе, не имеющем учёной степени) и не более 20000 знаков $(0,5$ а.л.) - для остальных авторов. Исключения по объёму возможны только по предварительной договорённости с редакцией.

Автор представляет текст статьи и сопроводительные сведения в печатном виде по почте (один экземпляр, на одной стороне листа) и идентичные материалы по электронной почте. Печатный вариант обязательно подписывается автором (авторами).

Текст статьи направляется в формате MS Word в соответствии со следующими параметрами: гарнитура Times Roman, размер шрифта - 14 кегль, межстрочный интервал - 1,5, сноски в порядке упоминания в тексте в конце текста арабскими цифрами. Графики и диаграммы для электронного варианта статьи выполняются в программе MS Excel и даются отдельным файлом, который должен содержать не только сами графические материалы, но и исходные данные (таблицы). Блок-схемы оформляются в формате MS Word или MS VISI0-2003.

Статье должен быть присвоен индекс УДК (располагается до заголовка статьи).

Статью должны сопровождать аннотация (600 - 700 знаков; предполагается описание следующих позиций: формулировка проблемы, указание методики исследования и источников информации, характеристика основных результатов исследования, варианты решения проблемы) и ключевые слова на русском и английском языках, библиографические списки.

К статье прилагаются (отдельным файлом) сведения об авторах статьи, содержащие: заголовок статьи (на русском и английском языках), фамилию, имя, отчество (полностью), учёную степень, учёное звание, полное название и адрес организации - места работы, занимаемую должность, телефон и факс, адрес электронной почты, почтовый адрес для переписки. 
К электронному варианту статьи прилагается цветная фотография автора (авторов) размером $4 \times 6$ см в формате tif (предпочтительно) или jpeg разрешением $300 \mathrm{dpi}$.

В соответствии с требованиями Гражданского кодекса РФ между авторами и редакцией журнала должен быть заключён Лицензионный договор с приложением к нему Акта приёма-передачи произведения. Эти документы, составленные по приведённой ниже форме и подписанные всеми авторами статьи, представляются в редакцию вместе с текстом статьи. Подписанный редакцией экземпляр договора будет направлен авторам по почте вместе с авторским экземпляром номера журнала.

Рукописи следует направлять Почтой России по адресу: 160014, г. Вологда, ул. Горького, 56а, ИСЭРТ РАН, редакция журнала, с пометкой «для публикации в журнале «Экономические и социальные перемены: факты, тенденции, прогноз», а также на электронный адрес: common@ vscc.ac.ru.

Факс: 8(8172)59-78-02. Тел.: 8(8172)59-78-31.

При полной или частичной перепечатке рукописей в другом издании обязательна ссылка на журнал.

Все рукописи подлежат рецензированию. Если у рецензента возникают вопросы, статья возвращается на доработку. Датой поступления статьи считается дата получения редакцией окончательного варианта статьи. Редакция оставляет за собой право внесения редакторских изменений и сокращений, не искажающих смысла статьи.

С 2010 года в журнале открыта рубрика «Молодые исследователи», в которой публикуются рукописи аспирантов. Статья должна быть без соавтора, заверена научным руководителем, рекомендована научной организацией, за которой закреплён аспирант.

Внимание! В случае несоблюдения указанных требований статья редакцией не рассматривается. С электронной версией журнала можно ознакомиться по адресу: http://esc.vscc.ac.ru. 


\section{Лицензионный договор №}

года

Федеральное государственное бюджетное учреждение науки Институт социально-экономического развития территорий Российской академии наук, именуемое в дальнейшем «Лицензиат», в лице действующего на основании доверенности , с одной стороны, и

именуемый(ая)

в дальнейшем «Лицензиар», с другой стороны, именуемые в дальнейшем «Сторона/Стороны», заключили настоящий договор (далее - «Договор») о нижеследующем.

\section{1. Предмет Договора}

1.1. По настоящему Договору Лицензиар предоставляет Лицензиату неисключительные права на использование статьи

(наименование, характеристика передаваемых Издателю материалов)

именуемой в дальнейшем «Произведение», в обусловленных договором пределах и на определенный договором срок.

1.2. Лицензиар гарантирует, что он обладает исключительными авторскими правами на передаваемое Лицензиату Произведение.

\section{2. Права и обязанности Сторон}

2.1. Лицензиар предоставляет Лицензиату на срок 5 (Пять) лет следующие права:

2.1.1. право на воспроизведение Произведения (опубликование, обнародование, дублирование, тиражирование или иное размножение Произведения) без ограничения тиража экземпляров. При этом каждый экземпляр Произведения должен содержать имя автора Произведения;

2.1.2. право на распространение Произведения любым способом;

2.1.3. право на переработку Произведения (создание на его основе нового, творчески самостоятельного произведения) и право на внесение изменений в Произведение, не представляющих собой его переработку;

2.1.4. право на публичное использование Произведения и демонстрацию его в информационных, рекламных и прочих целях;

2.1.5. п право на доведение до всеобщего сведения;

2.1.6. п право переуступить на договорных условиях частично или полностью полученные по настоящему договору права третьим лицам без выплаты Лицензиару вознаграждения.

2.2. Лицензиар гарантирует, что Произведение, права на использование которого переданы Лищензиату по настоящему Договору, является оригинальным произведением Лищензиара.

2.3. Лицензиар гарантирует, что данное Произведение никому ранее официально (т.е. по формально заключённому договору) не передавалось для воспроизведения и иного использования.

2.4. Лицензиар передает права Лицензиату по настоящему Договору на основе неисключительной лицензии.

2.5. Лицензиар обязан предоставить Лицензиату Произведение в печатной/электронной версии для ознакомления. В течение 60 (Шестидесяти) рабочих дней, если Лицензиатом не предъявлены к Лицензиару требования или претензии, связанные с качеством (содержанием) или объёмом предоставленной для ознакомления рукописи Произведения, Стороны подписывают Акт приёмапередачи Произведения.

2.6. Дата подписания Акта приёма-передачи Произведения является моментом передачи Лицензиату прав, указанных в настоящем Договоре.

2.7. Лицензиат обязуется соблюдать предусмотренные действующим законодательством авторские права, права Лицензиара, а также осуществлять их защиту и принимать все возможные меры для предупреждения нарушения авторских прав третьими лицами.

2.8. Территория, на которой допускается использование прав на Произведение, не ограничена. 


\section{3. Ответственность Сторон}

3.1. Лицензиар и Лицензиат несут в соответствии с действующим законодательством РФ имущественную и иную юридическую ответственность за неисполнение или ненадлежащее исполнение своих обязательств по настоящему Договору.

3.2. Сторона, ненадлежащим образом исполнившая или не исполнившая свои обязанности по настоящему Договору, обязана возместить убытки, причинённые другой Стороне, включая упущенную выгоду.

\section{4. Конфиденциальность}

Условия настоящего Договора и дополнительных соглашений к нему конфиденциальны и не подлежат разглашению.

\section{5. Заключительные положения}

5.1. Все споры и разногласия Сторон, вытекающие из условий настоящего Договора, подлежат урегулированию путём переговоров, а в случае их безрезультатности указанные споры подлежат разрешению в суде в соответствии с действующим законодательством РФ.

5.2. Настоящий Договор вступает в силу с момента подписания обеими Сторонами настоящего Договора и Акта приема-передачи Произведения.

5.3. Настоящий Договор действует до полного выполнения Сторонами своих обязательств по нему.

5.4. Срок действия настоящего Договора автоматически продлевается на каждый следующий пятилетний срок, если ни одна из сторон не выступила с инициативой его расторжения не позднее, чем за один месяц до истечения срока его действия.

5.5. Расторжение настоящего Договора возможно в любое время по обоюдному согласию Сторон, с обязательным подписанием Сторонами соответствующего соглашения об этом.

5.6. Расторжение настоящего Договора в одностороннем порядке возможно в случаях, предусмотренных действующим законодательством, либо по решению суда.

5.7. Любые изменения и дополнения к настоящему Договору вступают в силу только в том случае, если они составлены в письменной форме и подписаны обеими Сторонами настоящего Договора.

5.8. Во всём, что не предусмотрено настоящим Договором, Стороны руководствуются нормами действующего законодательства РФ.

5.9. Настоящий Договор составлен в двух экземплярах, имеющих одинаковое содержание и равную юридическую силу, по одному для каждой из Сторон.

\section{6. Реквизиты Сторон}

\section{Лицензиат:}

\section{ИСЭРТ РАН}

ИНН 3525086170 / КПП 352501001

160014 г. Вологда, ул. Горького, 56а

УФК по Вологодской области (ИСЭРТ РАН

лиц. сч. 20306Ц32570)

$\mathrm{P} / \mathrm{c} 40501810400092000001$

ГРКЦ ГУ Банка России по Вологодской

области, г. Вологда

БИК 041909001, ОКПО 22774067

OKATO 19401000000

\section{Лищензиар:}

Ф.И.О

Дата рождения:

Домашний адрес:

Паспорт:серия___ номер

выдан

когда выдан

ИНН

Свидетельство государственного пенсионного страхования

$\frac{\text { подпись }}{\text { ф. и. о. полностью }} /$




\section{AKT \\ приёма-передачи произведения}

г. Вологда

$\ll$

20

года

Федеральное государственное бюджетное учреждение науки Институт социально-экономического развития территорий Российской академии наук, именуемое в дальнейшем «Лицензиат», в лице

действующего на основании доверенности с одной стороны, и

, именуемый(ая) в дальнейшем «Лицензиар», с другой стороны, именуемые в дальнейшем «Сторона/Стороны», составили настоящий акт о том, что Лицензиар предоставил Лицензиату Произведение

в печатной/электронной

версии для использования в соответствии с подписанным сторонами Лицензионным договором № от « 2012 года.

Передал

Лицензиар:
Принял

От Лицензиата:

М. П. 


\title{
ИНФОРМАЦИЯ О ПОДПИСКЕ
}

\author{
Уважаемые коллеги! \\ Предлагаем Вам оформить подписку на журнал \\ «Экономические и социальные перемены: факты, тенденции, прогноз».
}

Учредитель: Федеральное государственное бюджетное учреждение науки «Институт социально-экономического развития территорий РАН» (ИСЭРТ РАН).

В журнале публикуются результаты исследований по оценке эффективности функционирования региональных социально-экономических систем Северо-Западного федерального округа России, секторов экономики субъектов округа и муниципальных образований по направлениям:

- стратегия развития;

- региональная экономика;

- социальное развитие;

- внешнеэкономические отношения;

- информационная экономика;

- проблемы расширенного воспроизводства и др.

Журнал включён в Российский индекс научного цитирования (РИНЦ).

Решением Президиума Высшей аттестационной комиссии Минобрнауки России №6/6 от 19 февраля 2010 года журнал включён в Перечень ведущих научных изданий, рекомендуемых для публикации основных результатов диссертаций на соискание учёной степени доктора и кандидата наук.

Главная цель издания - предоставление широким слоям научной общественности и практическим работникам возможности знакомиться с результатами научных исследований в области научного обеспечения региональной экономики, принимать участие в обсуждении этих проблем.

Редакционная коллегия, осуществляющая независимую экспертизу научных статей, состоит из ведущих ученых ряда регионов России.

Журнал выходит 6 раз в год.

Журнал включён в межрегиональную часть каталога российской прессы «Пресса России»: подписной индекс 41319.

Каталожная цена одного номера журнала составляет 250 руб. (без учёта доставки). Подготовленный подписной бланк приведён в приложении. 


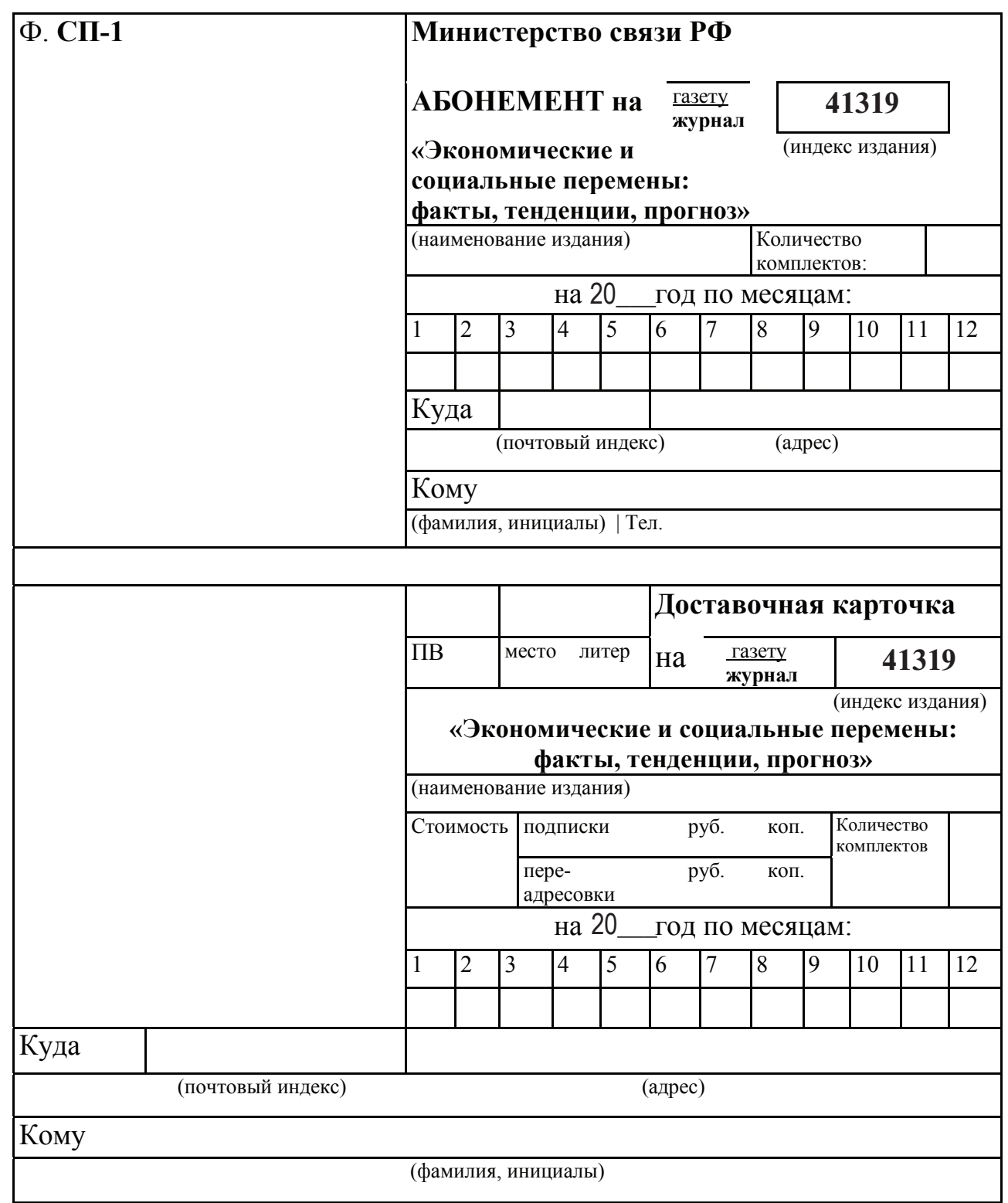




\section{Редакционная подготовка Оригинал-макет}

Корректор
П.Н. Воронина

Т.В. Попова

В.В. Ригина

Н.С. Киселева

Подписано в печать 27.02.2014.

Дата выхода в свет 03.03.2014.

Формат $60 \times 84 \frac{1}{8}$. Печать цифровая.

Усл. печ. л. 25,7. Тираж 500 экз. Заказ №53.

Цена свободная.

Журнал зарегистрирован Федеральной службой по надзору в сфере связи, информационных технологий и массовых коммуникаций (Роскомнадзор). Свидетельство ПИ № ФС77-49490 от 20 апреля 2012 г.

Учредитель: Федеральное государственное бюджетное учреждение науки Институт социально-экономического развития территорий Российской академии наук (ИСЭРТ РАН)

Адрес издателя и редакции:

160014 , г. Вологда, ул. Горького, 56a,

телефон (8172) 59-78-03, факс (8172) 59-78-02, e-mail: common@vscc.ac.ru 